\title{
صيغ المعمولات
}

\section{بين الانتراض النحوي والواقع اللغوي}

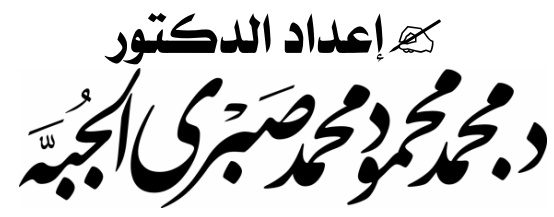

مدرس اللغويات في كلية الدراسات الإسلاهية والعربية

$$
\text { بدهياط الجديدة - جامعة الأزهر ـ هصر }
$$

MohammedAljabbeh.33@azhar.edu.eg 


\section{صيغ المعمولات بين الافتراض النحوي والواقع اللغوي}

محمد محمود محمد صبري الجوبسة

قسم اللغويات - كلية الدراسات الإسلامية والعربية للبنين - دمياط الجمديدة -

$$
\text { جامعة الأزهر - مصر العوير }
$$

البريد الالكتروني : MohammedAljabbeh.33@azhar.edu.eg

أتى هذا البحث ليَركِّز على ما فترضه النحاة في صيغ المعمو لات ومدى موافقة

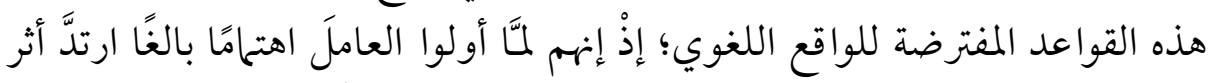

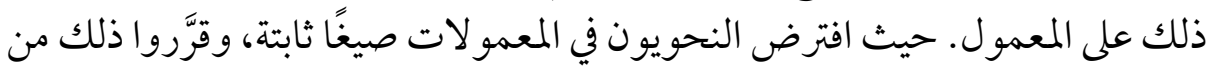

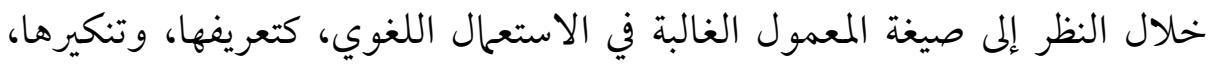

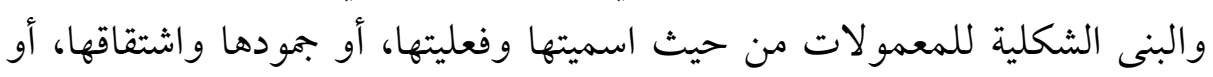

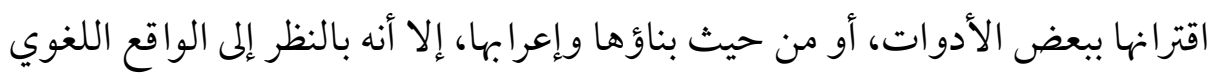

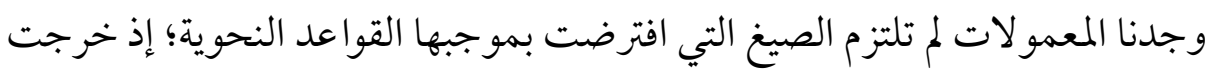

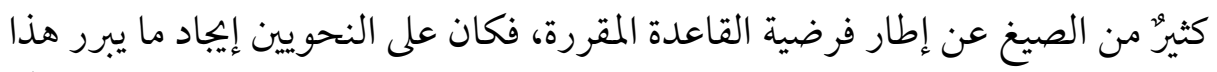

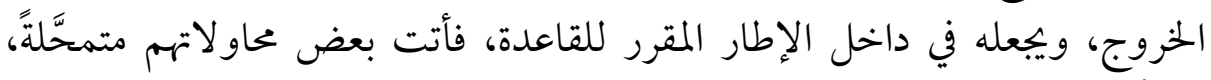

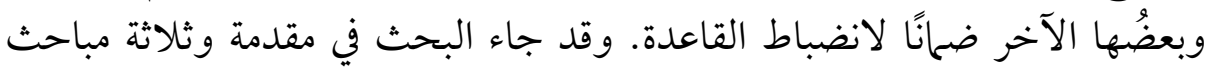

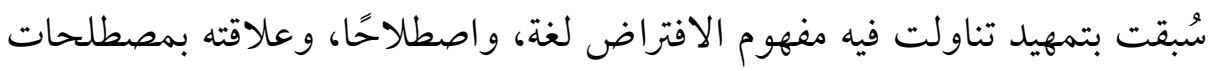

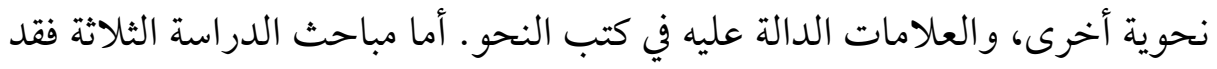

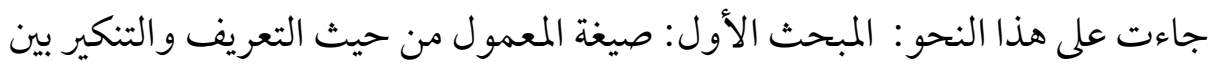

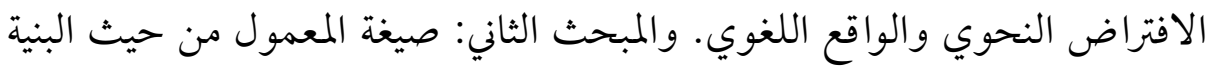

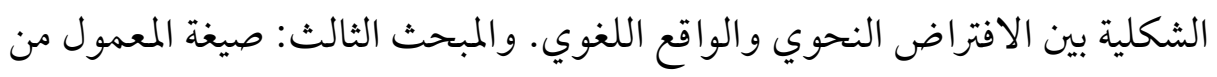

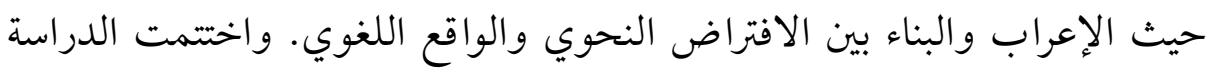

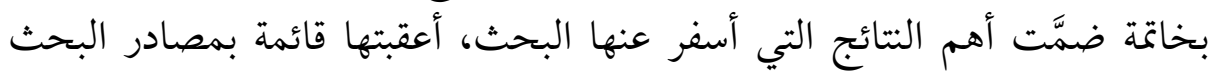
ومراجعه.

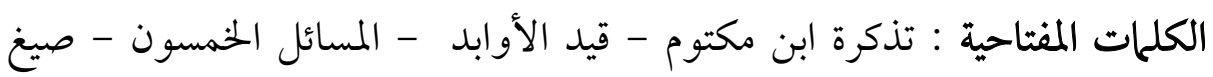

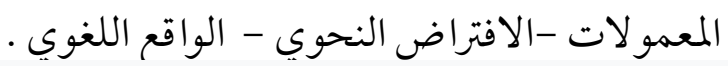




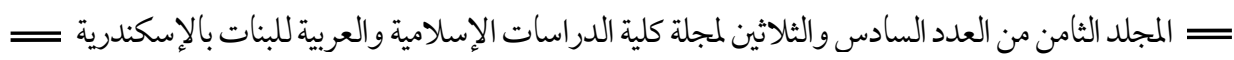
صيغ المعمولات بين الافتراض النحوي والواقع اللغوي النائ

\section{Formulas between syntactic assumptions and linguistic reality}

Muhammad Mahmoud Muhammad Sabri al-Jabbah

Linguistics Department - College of Islamic and Arabic

Studies for Boys - New Damietta - Al-Azhar University Egypt

e-mail: MohammedAljabbeh.33@azhar.edu.eg

\section{Abstract:}

This paper came to assure what was assumed by grammarians concerning predicate formulas and to show to what extent these hypothetical rules apply to linguistic reality ;since when they gave great interest to the subject, this affected the predicate. Grammarians have assumed fixed formulas of predicates. They decided to do so through observing the predicate formula which is common in linguistic use such as making it definite and indefinite ,using predicate forms as a noun or a verb, being aplastic or derivative, being connected with some articles or their declension and syntax .Though, through observing the linguistic reality, it was noticed that predicates didn't always restrict to the formulas assumed by grammar rules. A lot of formulas went away from the hypothesis of the applied rule, so grammarians had to find the cause of this and to find a way to restrict them to the applied frame of the rule. Some of their trials were glancing and others came to assure the rule's precision. This paper includes an introduction and three research elements preceded by a preface, in which I 


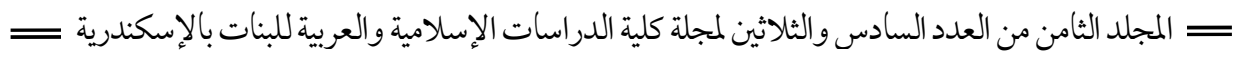
صيغ المعمولات بين الافتراض النحوي والواقع اللغوي

handled the meaning of hypothesis, linguistically and idiomatically , and its relationship with other grammatical idioms and its signs in grammar books. As for the three research elements, they came as follows: The first research element : Predicate formula as definite and indefinite between grammatical hypothesis and linguistic reality. The second research element :Predicate formula as a structure between grammatical hypothesis and linguistic reality. The third research element : Predicate formula in declension and syntax between grammatical hypothesis and linguistic reality. The study was concluded by a conclusion including the most important results of the research and it was followed by a list of the research resources and references .

Keywords: The Ibn Maktoum Remembrance - The Book of Al-Awad - The Fifty Issues - Formulas of Commitments - Syntactic Assumption - Linguistic Reality. 


\section{مقدهة - مقة}

$$
\text { بسم الله الرحمن الرحيم }
$$

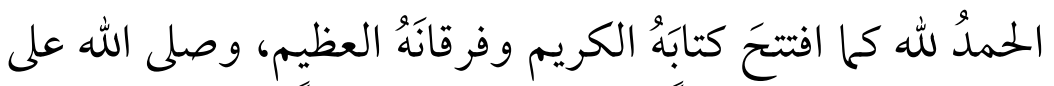

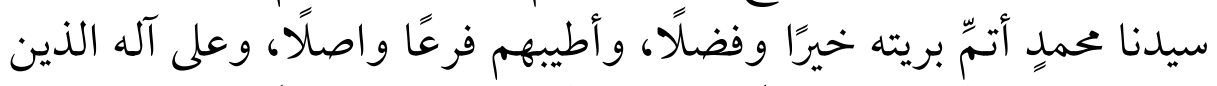

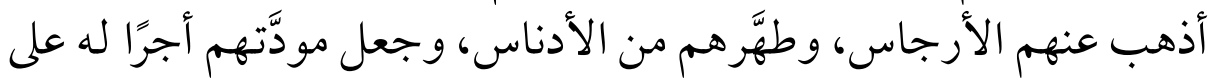

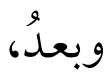

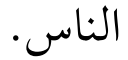

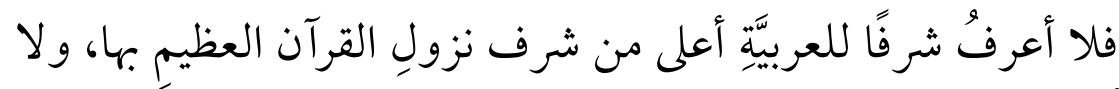

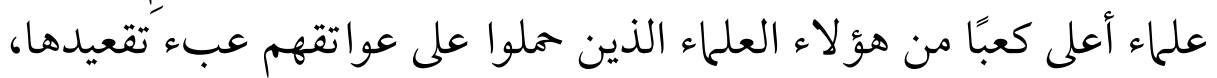

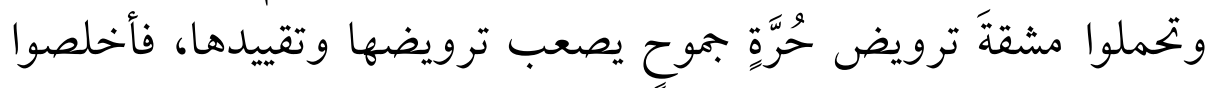

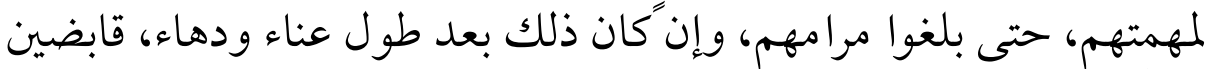

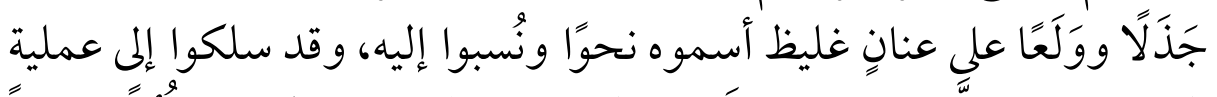

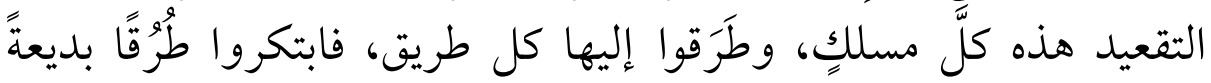

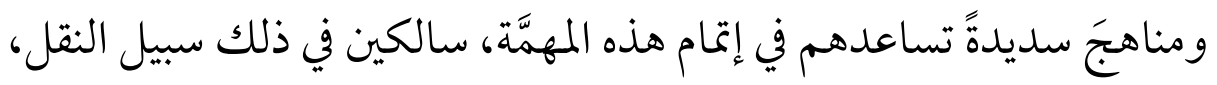
فأمَّا سبيلُ النَّقل فمعروفة مصادرُه، وأمَّا سبيلُ العقلٍ فأتت سبيلً

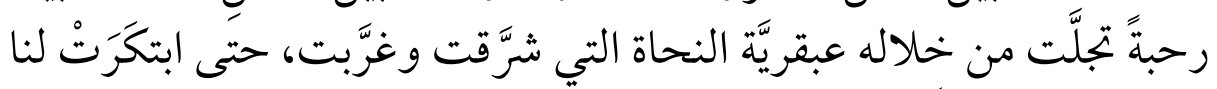

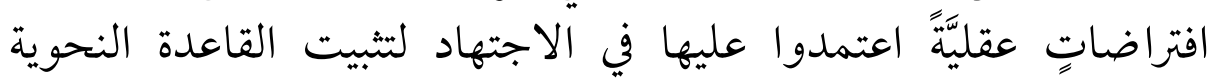
وتوطيدها، وشدّ معاقدها.

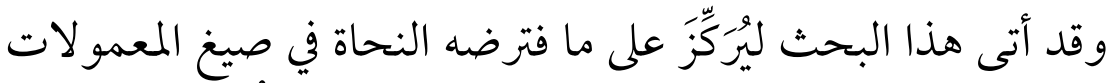

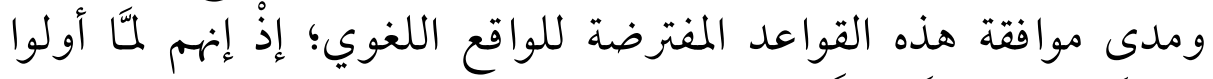

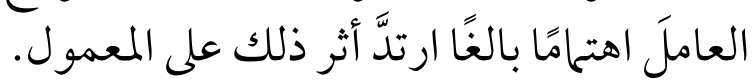

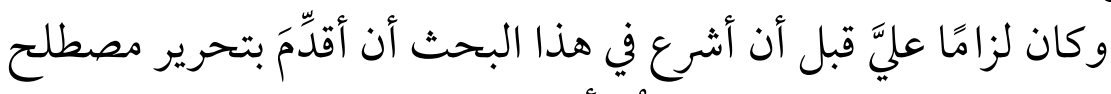

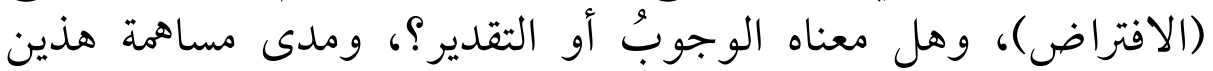


المعنيين في توطيد القاعدة النحوية، وفرض سلطانها على جميع أجزاء الظاهرة

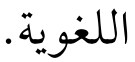

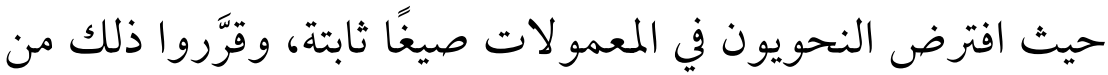

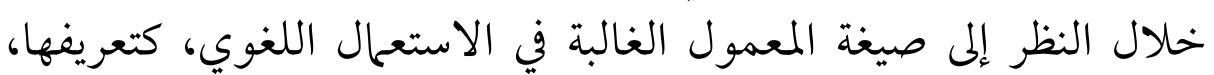

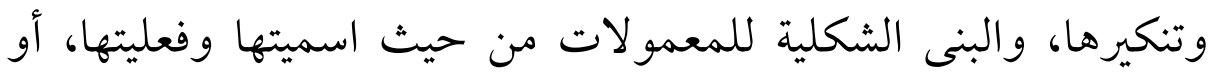

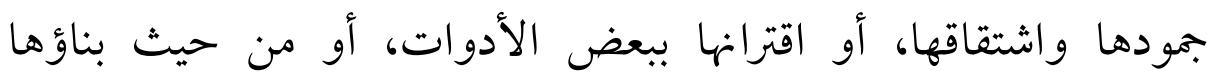

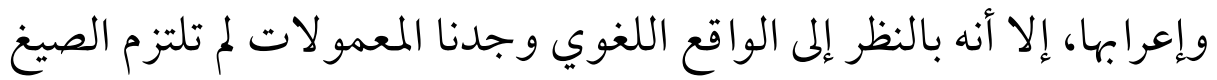

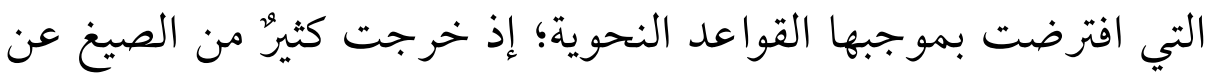

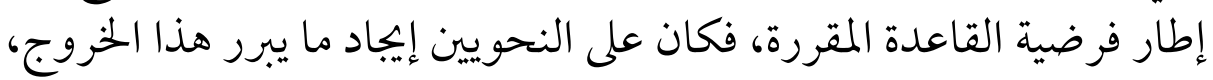

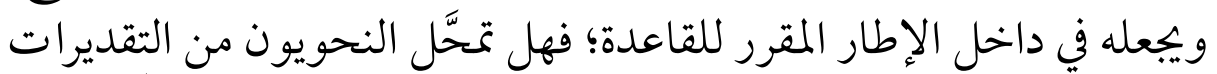

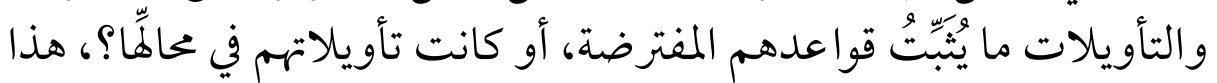
ما سيبيّنه البحث في طِيَّاته.

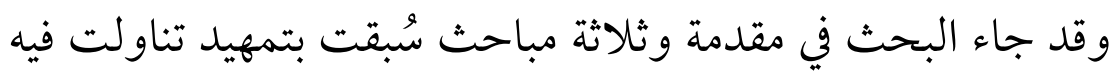

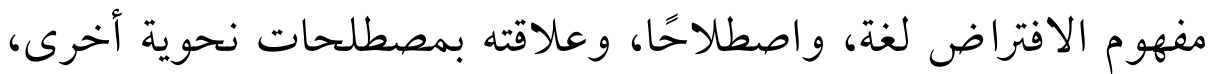

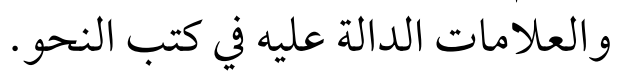

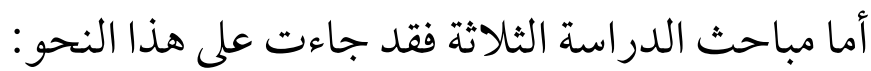

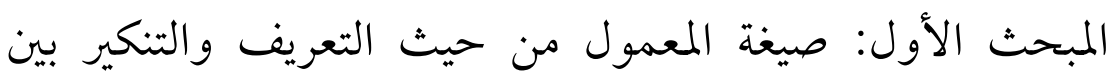
الافتراض النحوي والواقع اللغوي. المتحن المعتول والمبحث الثاني: صيغة المعمول من النع حيث البنية الشكلية بين الافتراض النحوي والواقع اللغوي.

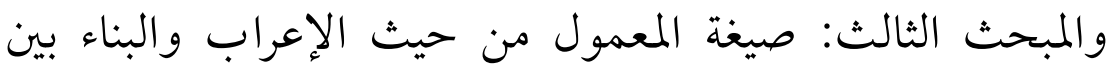
الافتراض النحوي والواقع اللغوي.

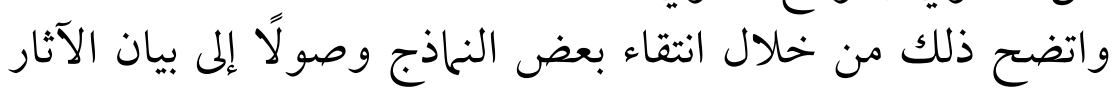
المترتبة على هذه الافتراضات.

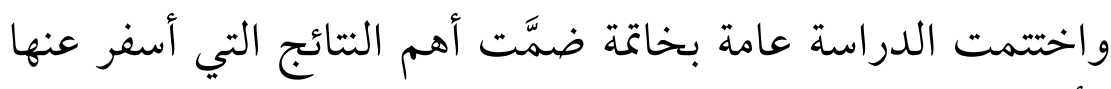

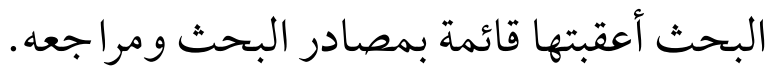




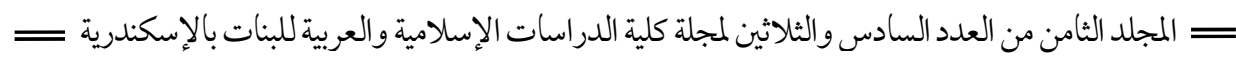

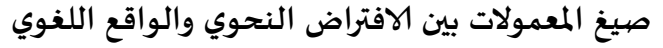

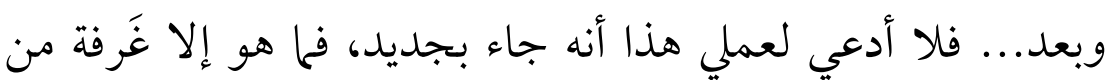

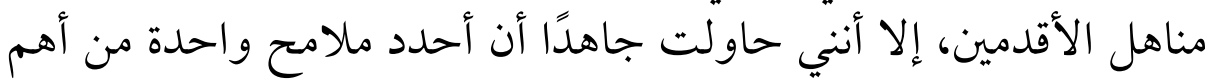

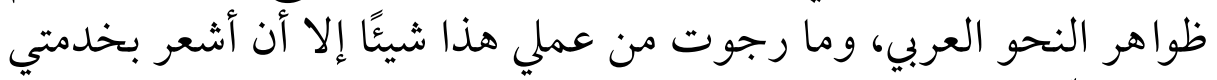

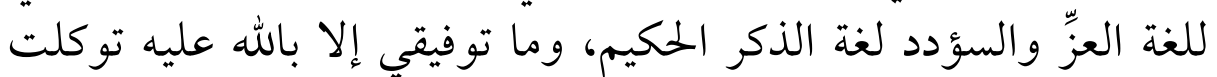
وإليه أنيب. لمنز.

الباحث 


\section{تهرير هصطاح (الافتزاض)}

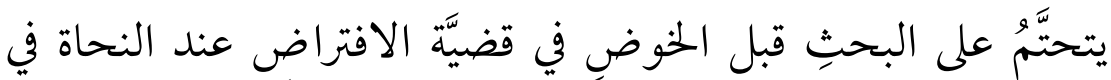

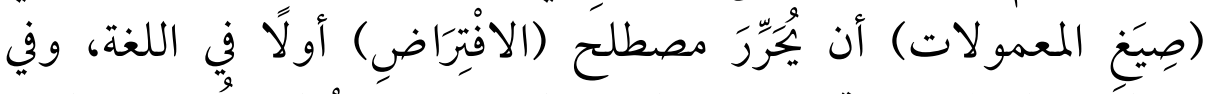

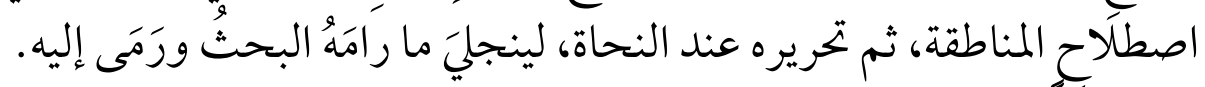

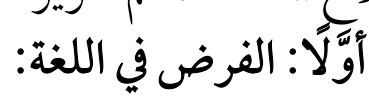

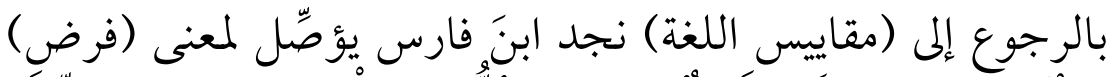

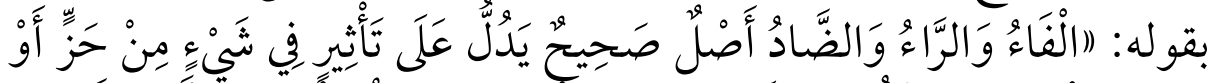

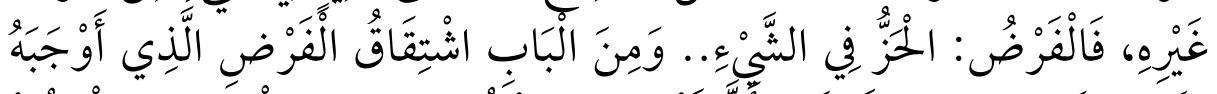

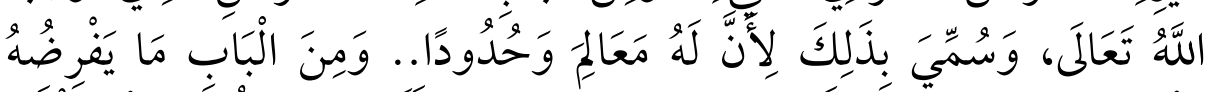

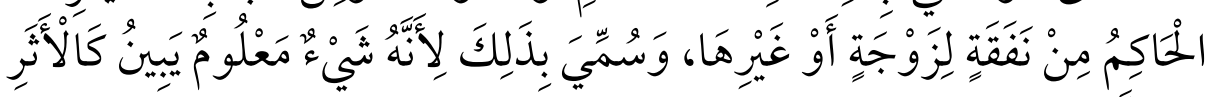

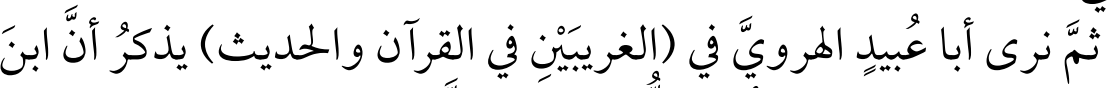

$$
\text { في الشَّيْهِ|(1). }
$$

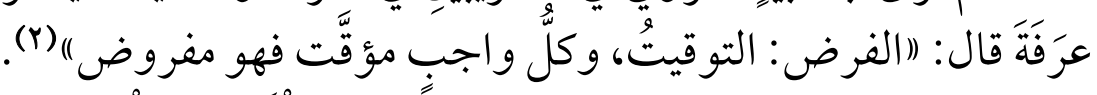

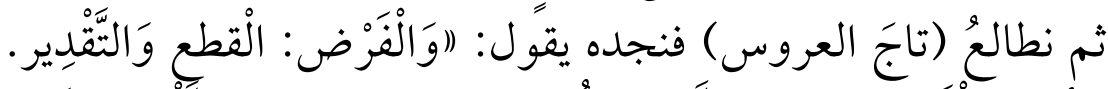

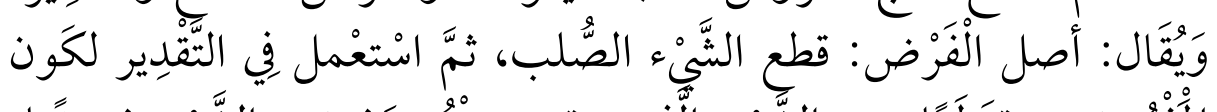

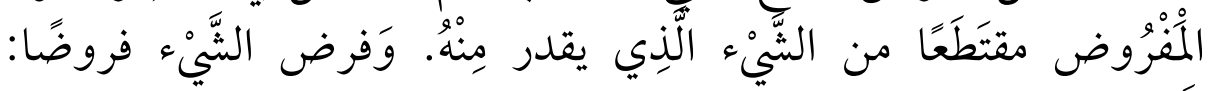

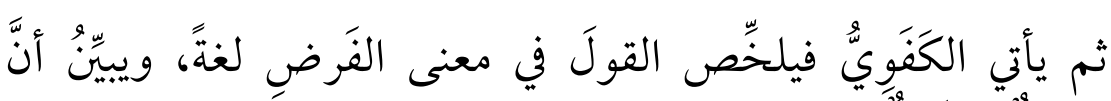
اتَّسع (ب)

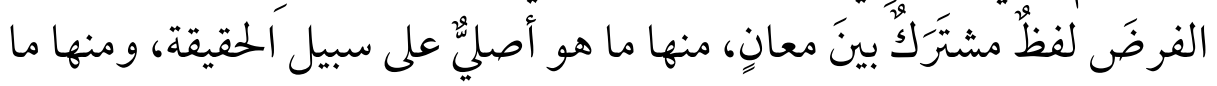

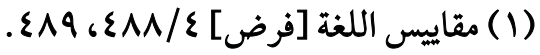

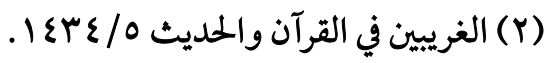

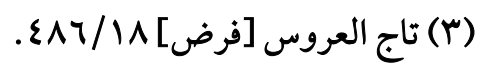




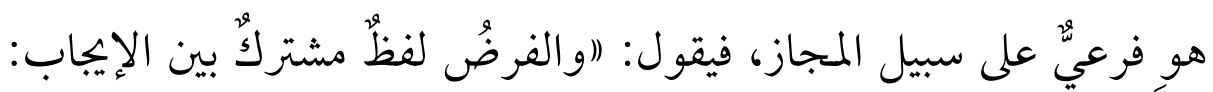

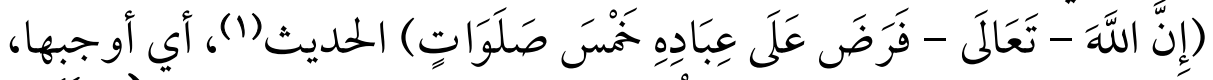

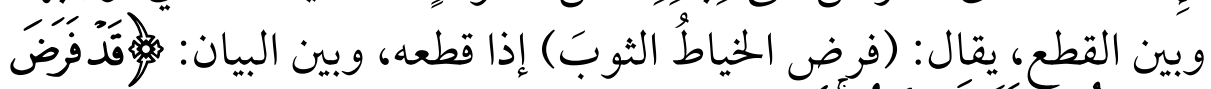

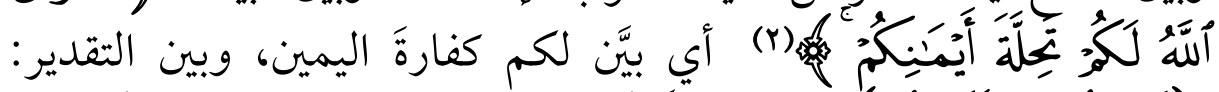

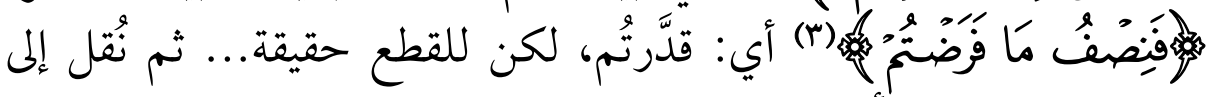

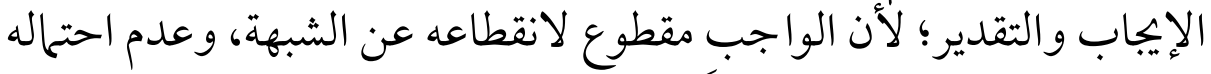

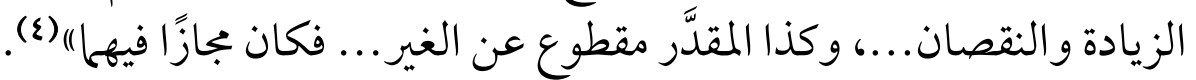
ثانيًا: الفرض في الاصطلاح:

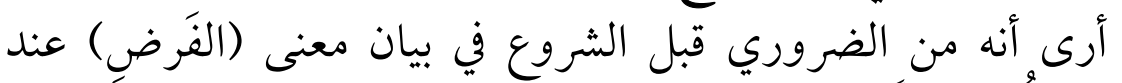

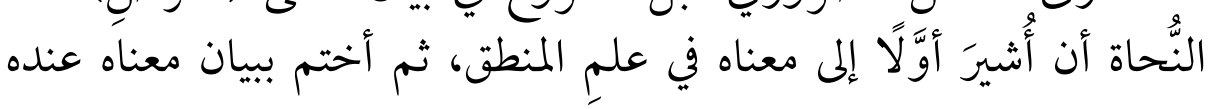
النحويين.

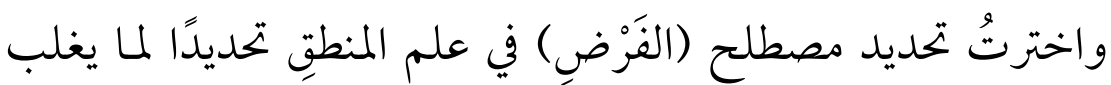

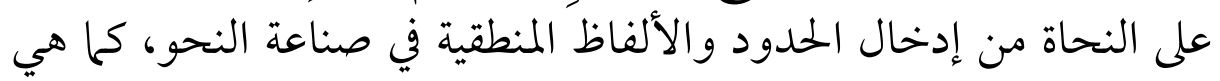

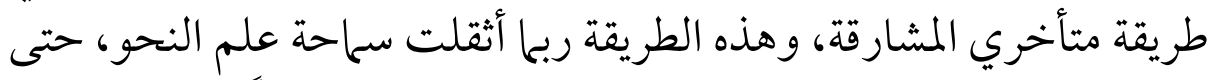

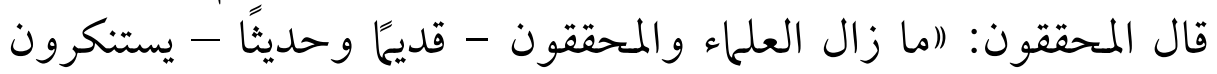

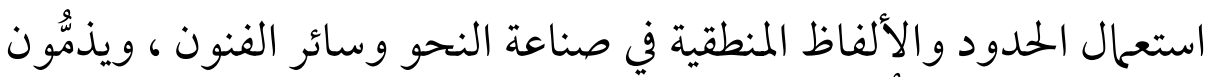

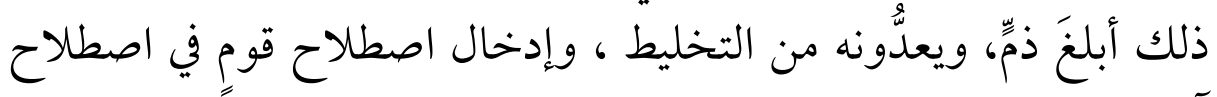
آخرين · تاك آن

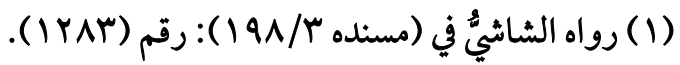

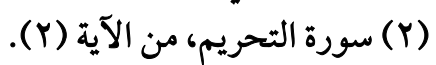

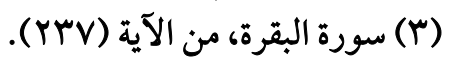

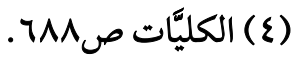


قال الإمام أبو محمد البطليوسي (1): ... جمعني مجلسٌ مع رجلٍ من أهل

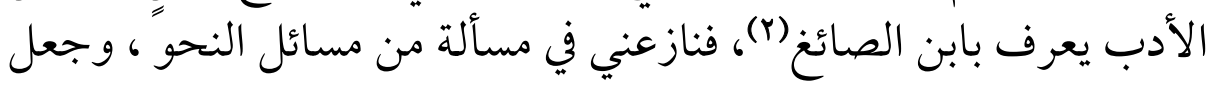

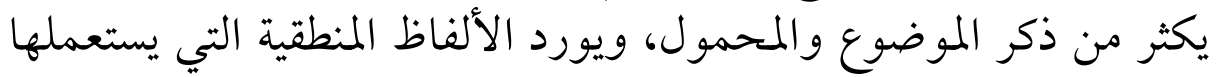

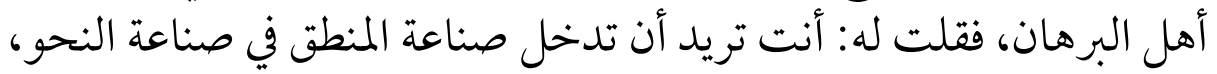

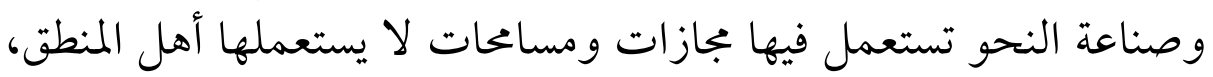

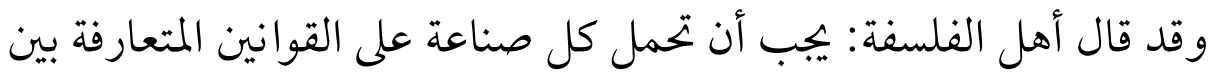

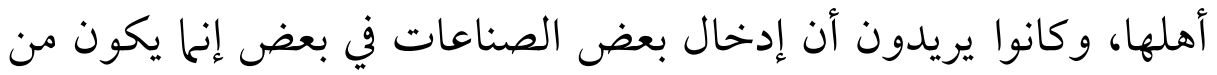

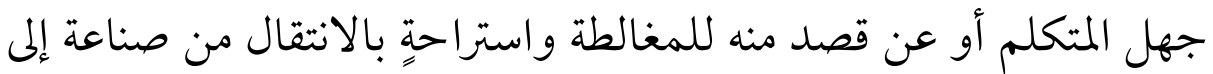

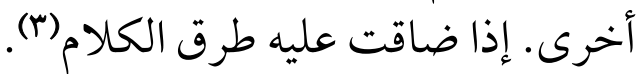

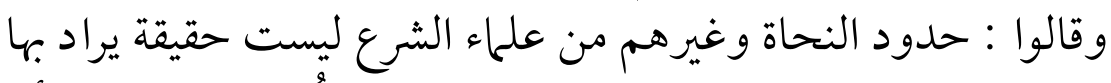

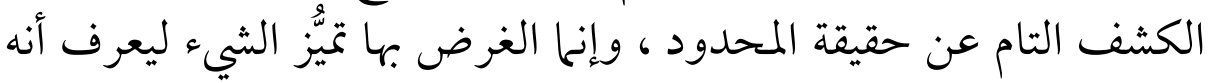

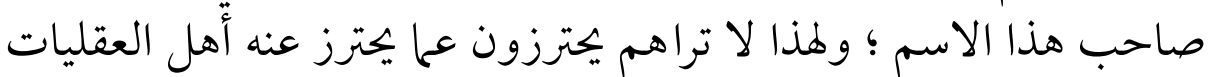

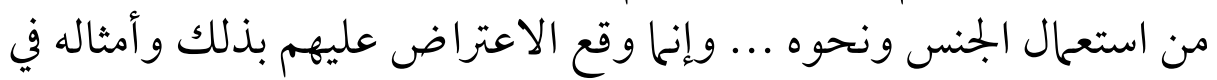

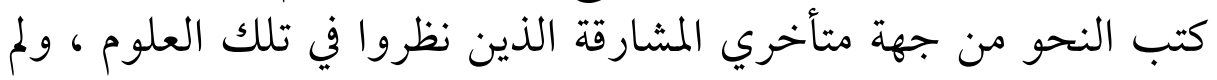

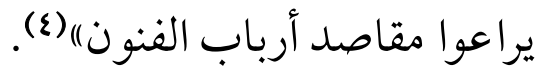

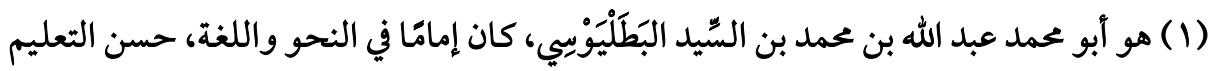

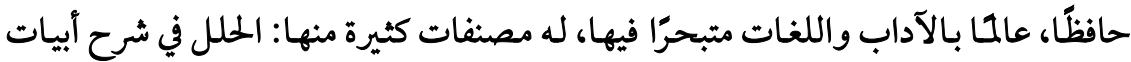

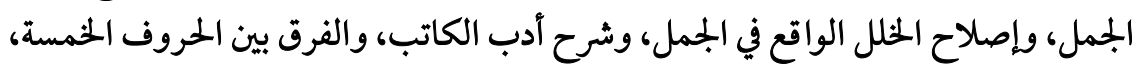

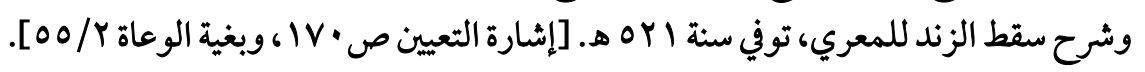

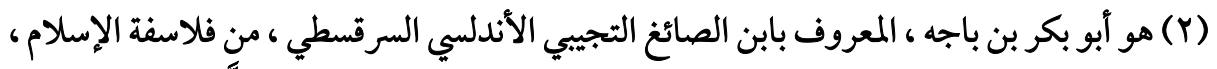

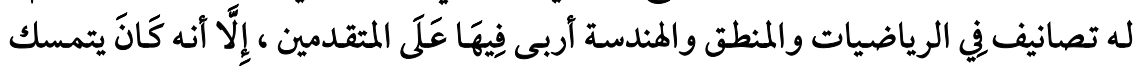

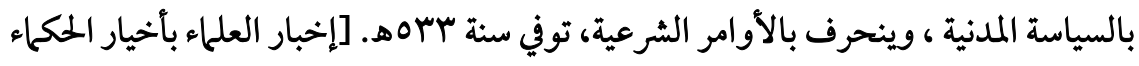

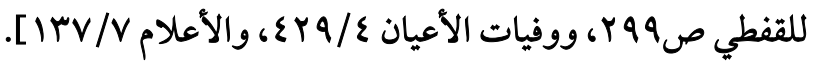

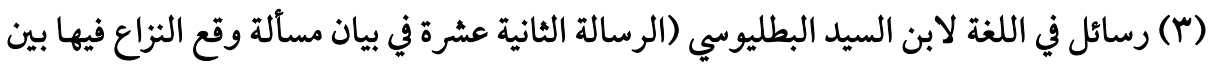

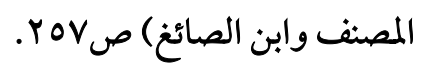

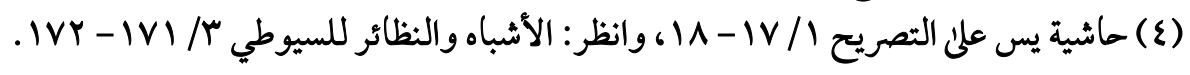




\section{أولاً: عند المناطقة: - ألماطة}

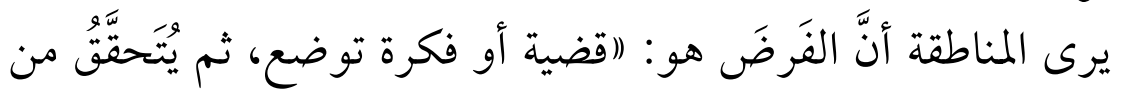

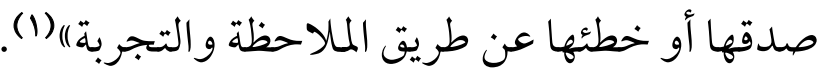

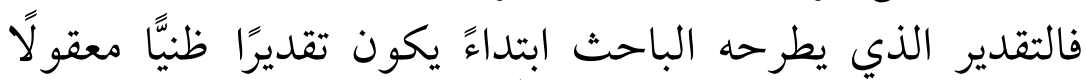

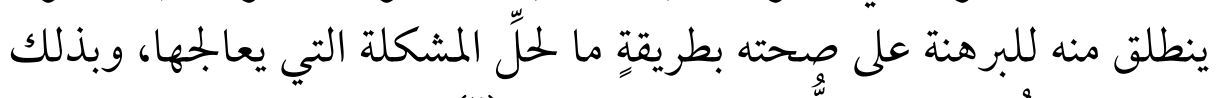

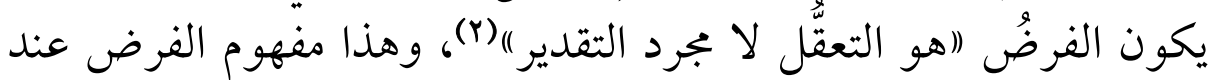

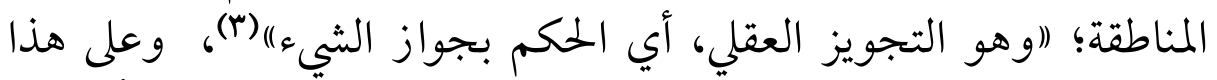

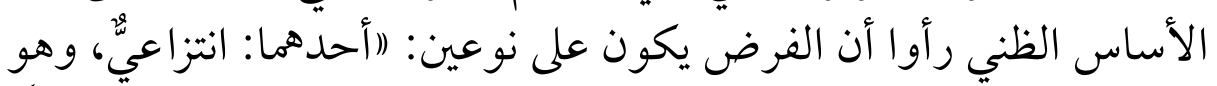

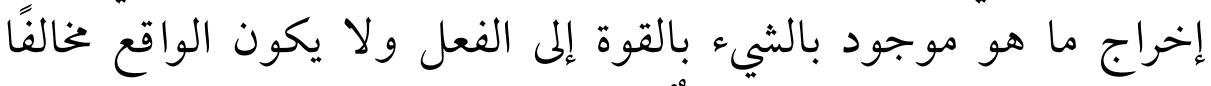

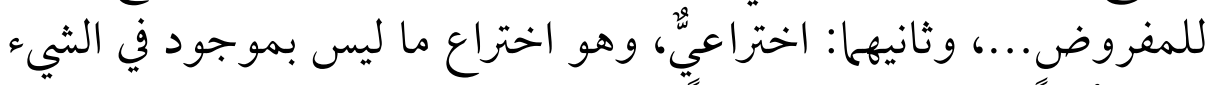

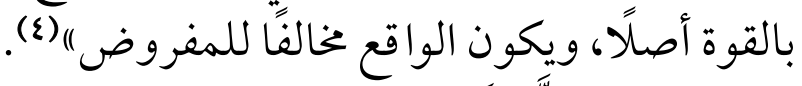

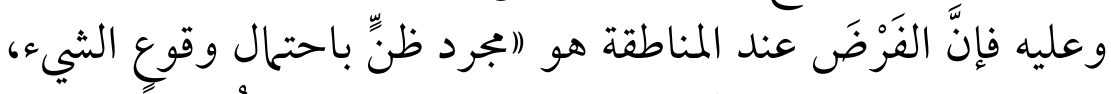

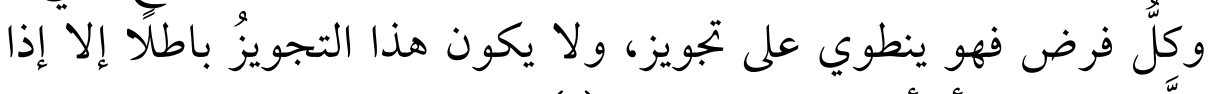

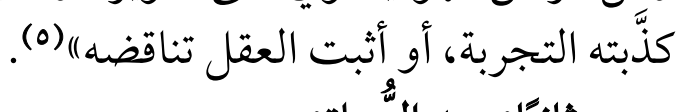
ثانيًا: عند النّحاة: أنبّة

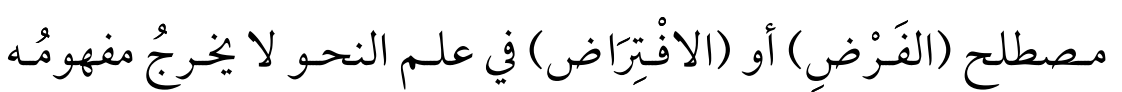

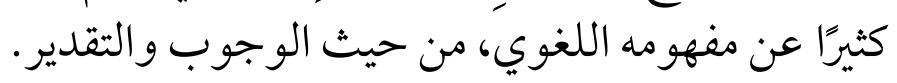

(1) انظر: المعجم الفلسفي (بجمع اللغة العربية) صهـ با [فرض]]، ومعجم اللغة العربية المعاصرة، د/

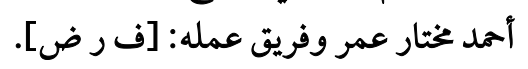

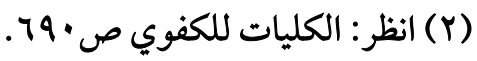

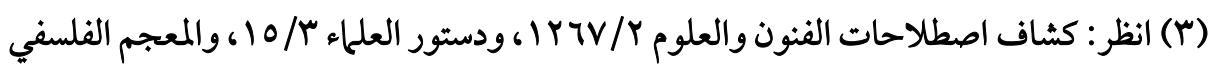

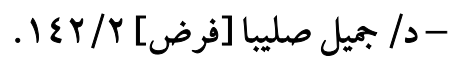

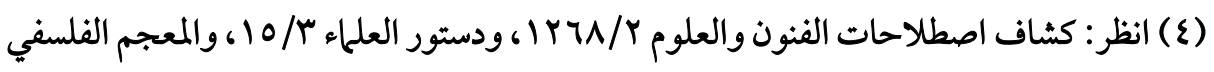
-

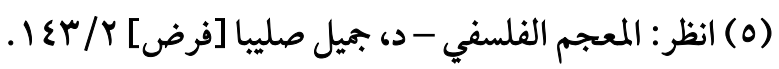




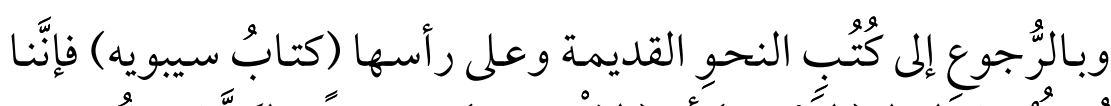

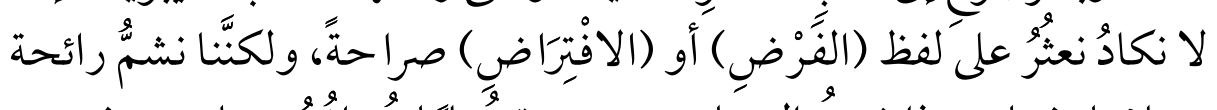

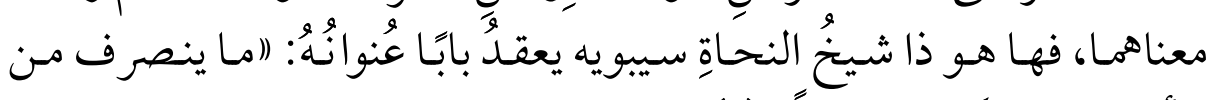

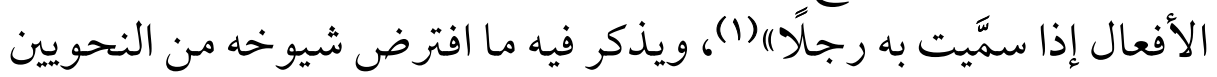

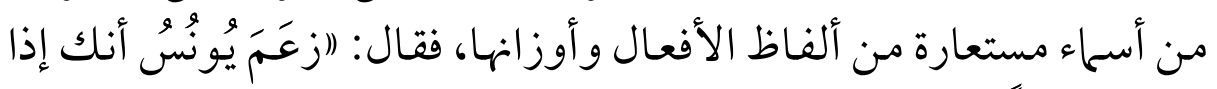

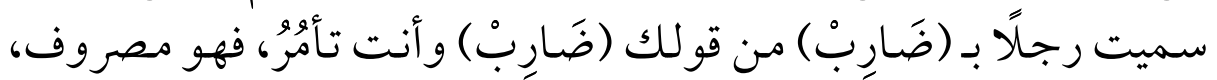

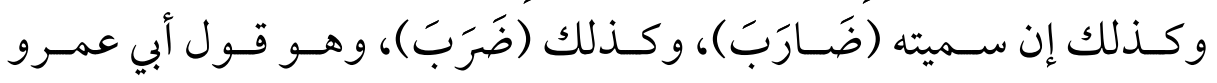

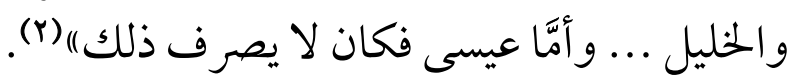

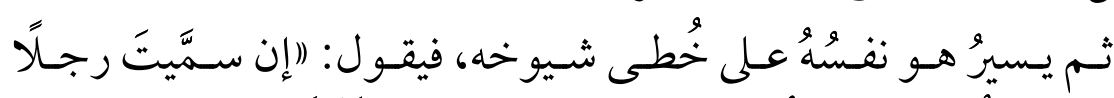

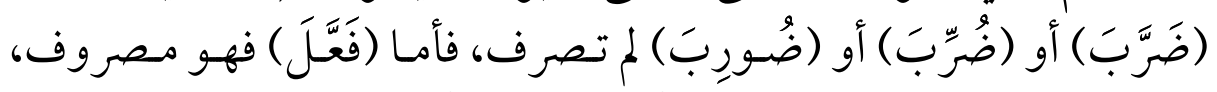

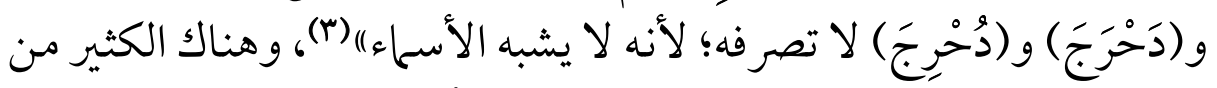

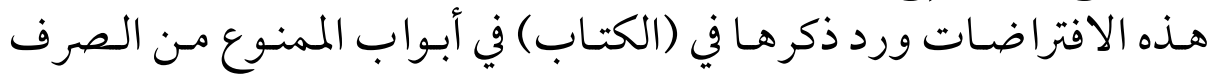

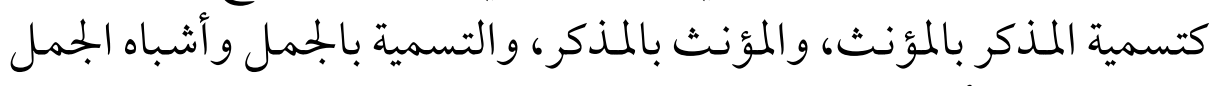
ويالحروف والأدوات.

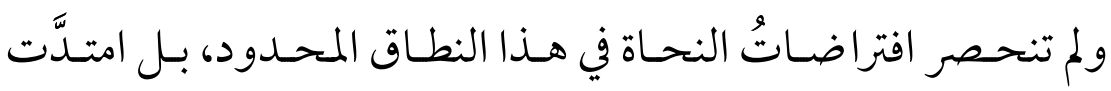

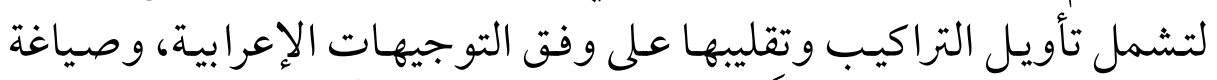

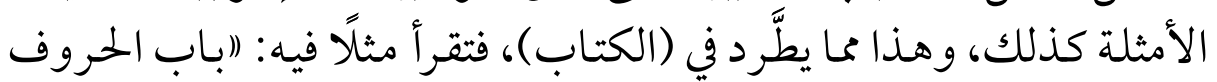

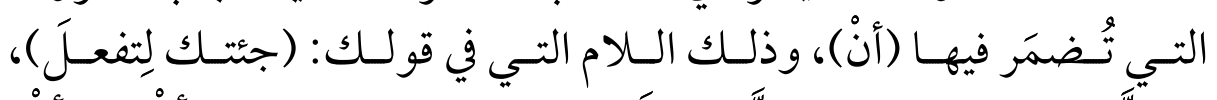

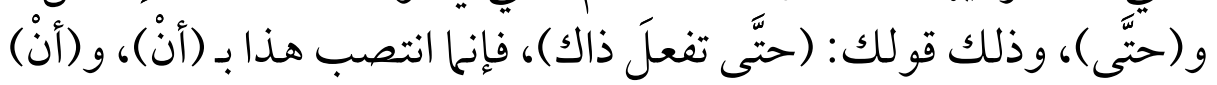

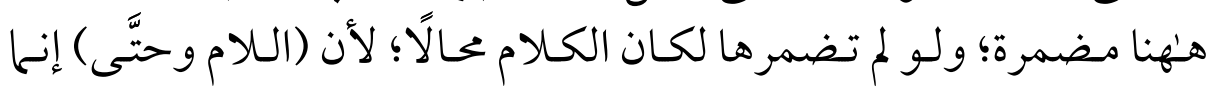

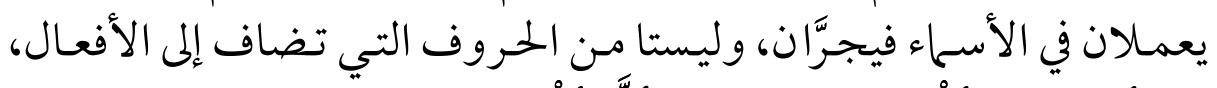

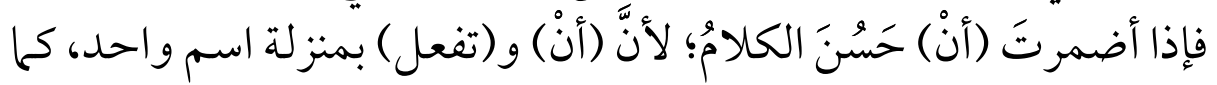




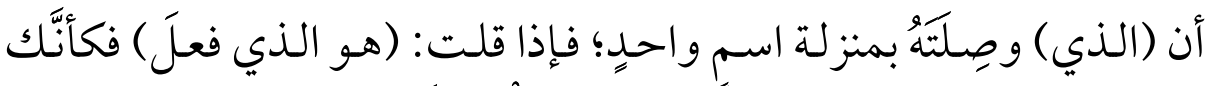

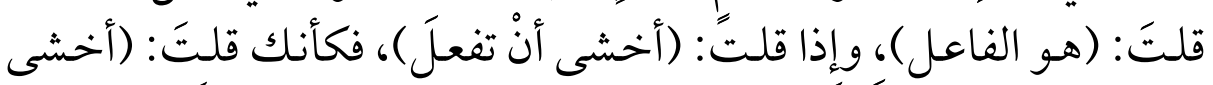

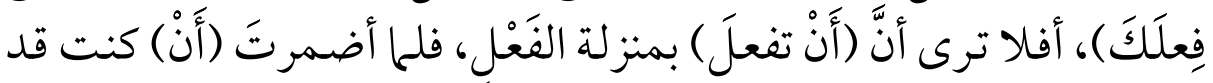

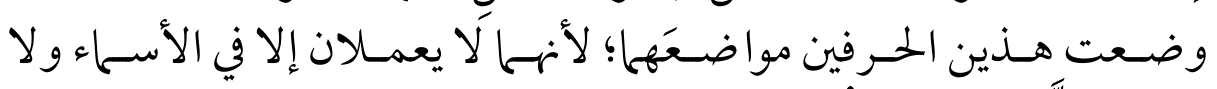

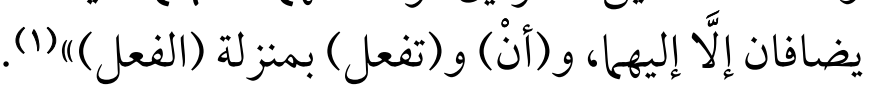

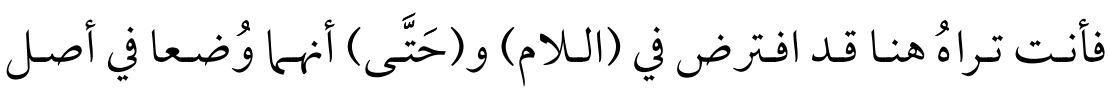

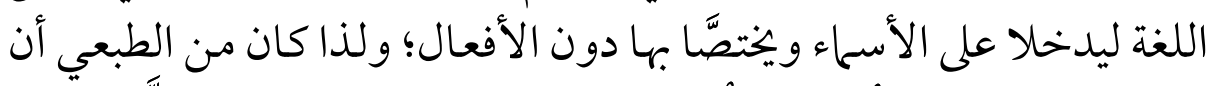

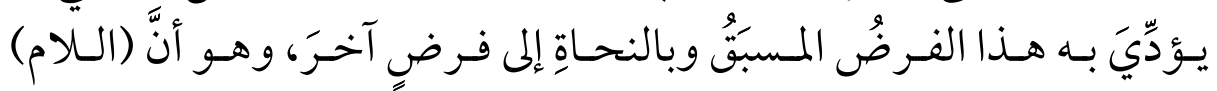

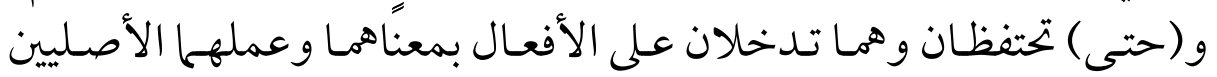

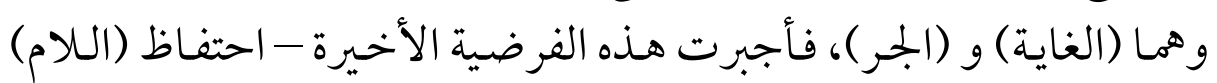

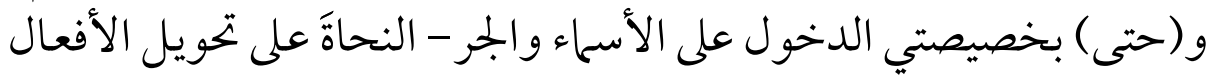

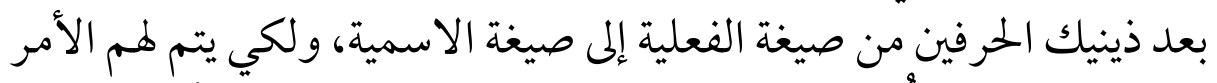

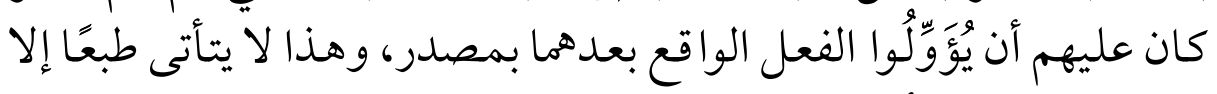

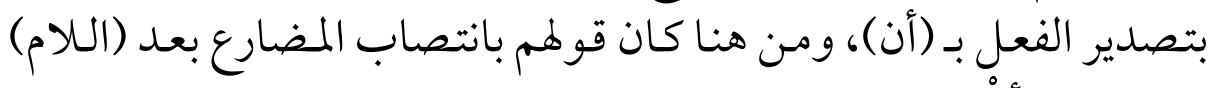
و (حتى) بـ (أنْ) مضمرة.

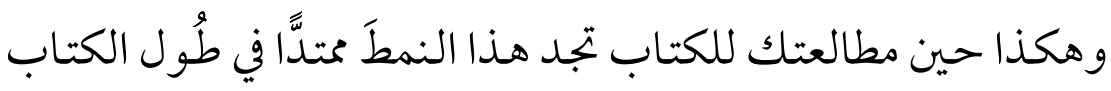

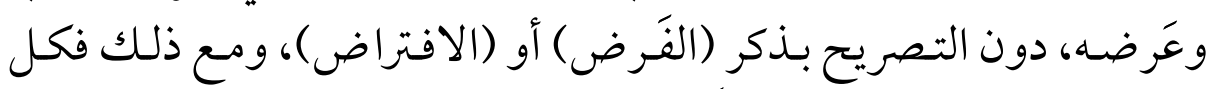

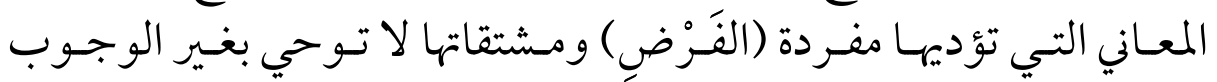
والتقدير. ثم يُفاجئك سيبويه في (كتابه) وهو يتحلَّث عن المصادر بجعله أحد

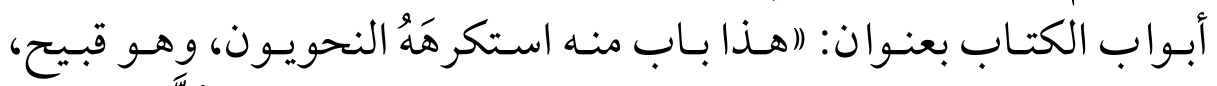

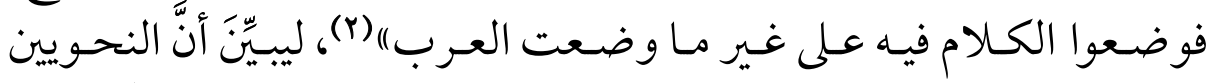

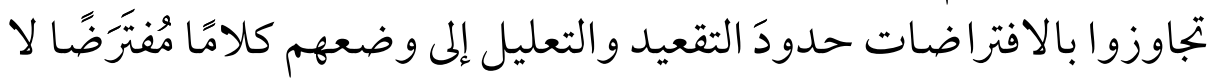


علاقة له بها وضعته العربُ، وفي كلام شيخ النحاة إشعارٌ بنقد صنيعهم إذا

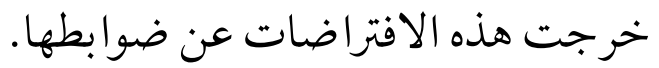

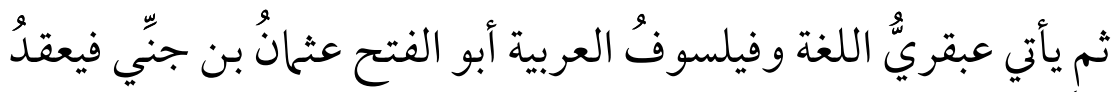

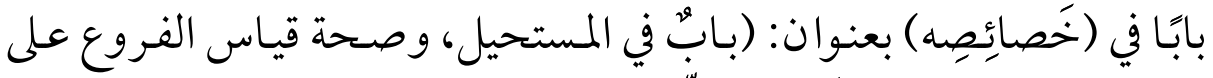

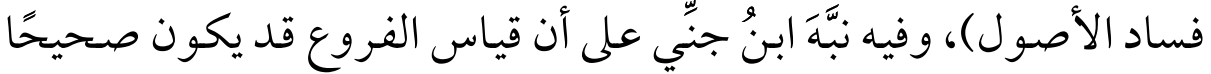

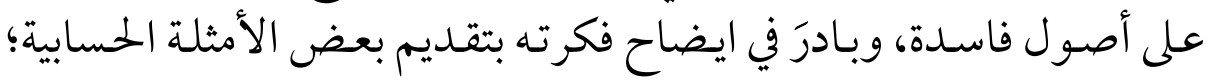
فقال:

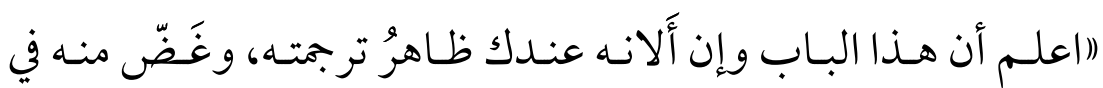

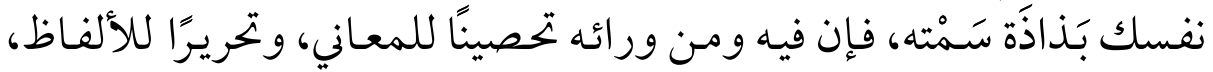

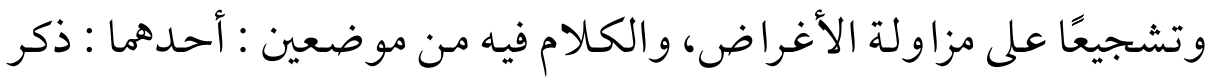

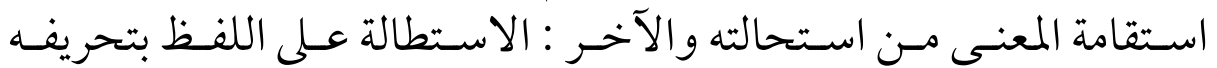

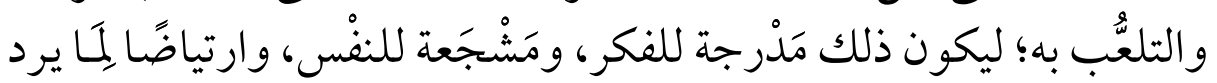

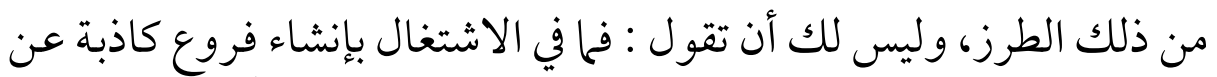

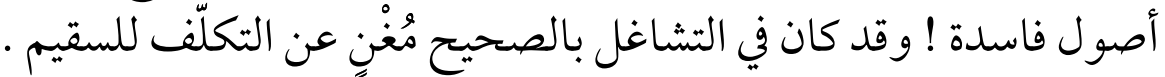

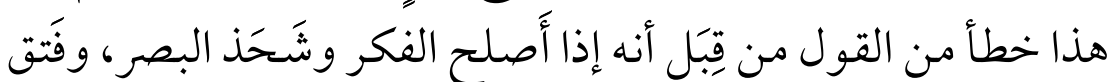

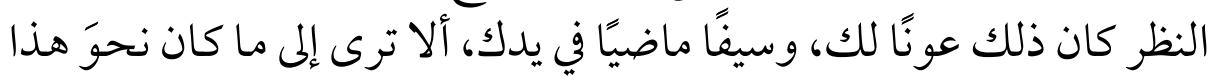
من الحساب وما فيه من التصرّف و الاعتهال.

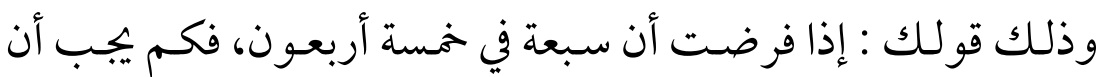

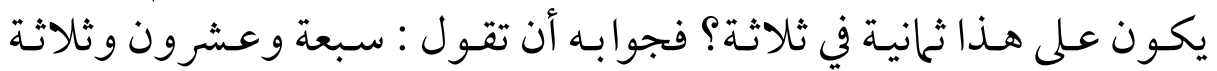

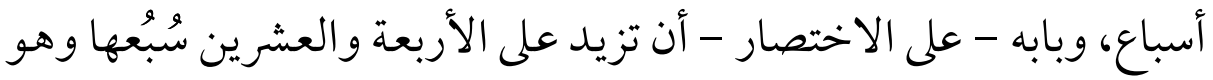

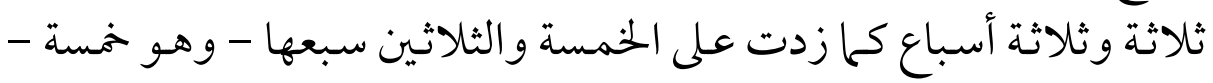
حتى صارت : أربعين

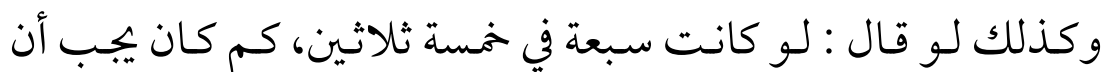

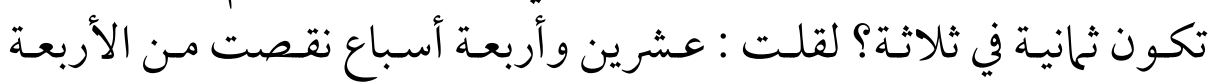

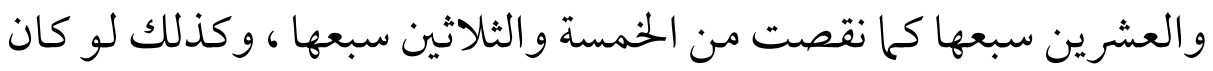




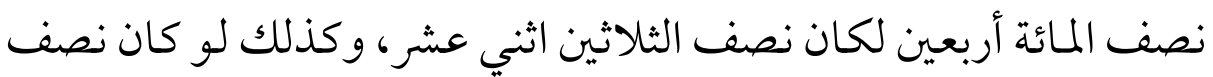
المائة ستّين لكان نصف الثلاثين ثمانية عشر |(1).

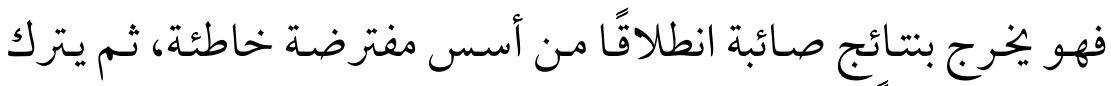

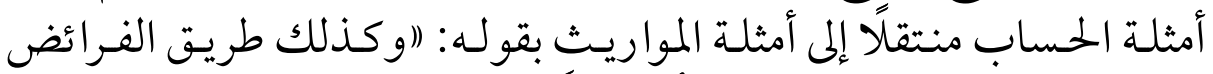

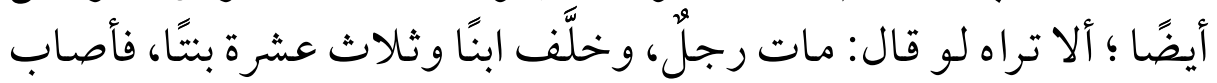

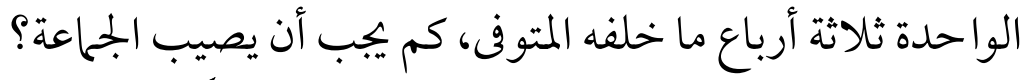

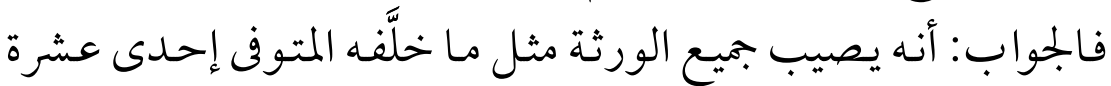

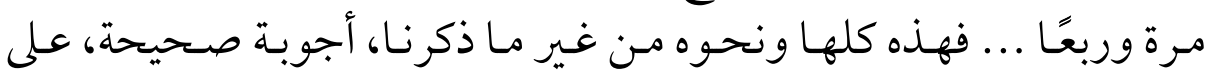

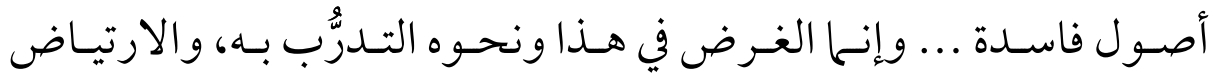

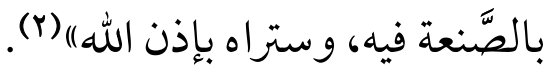

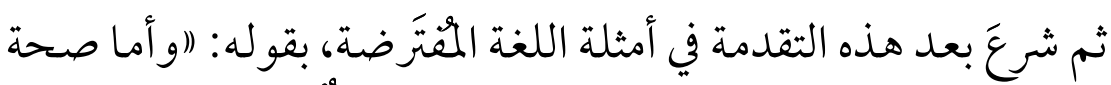

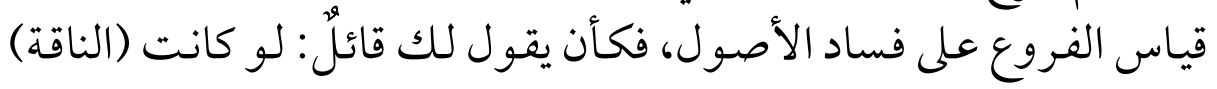

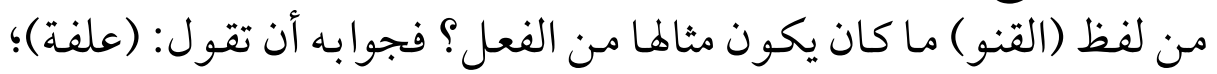

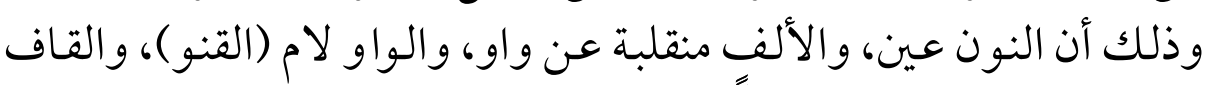

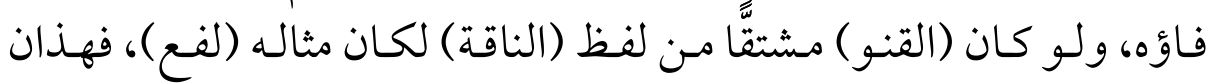

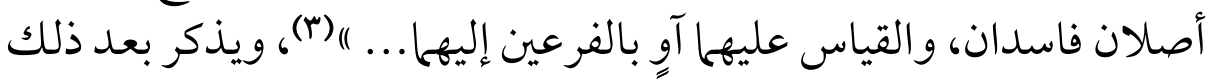
مجموعة من الأمثلة على النسق نفسه.

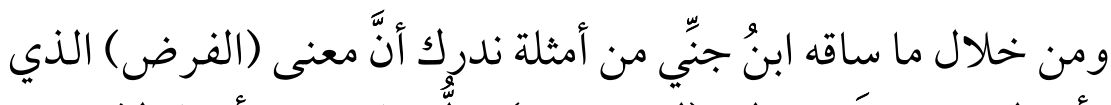

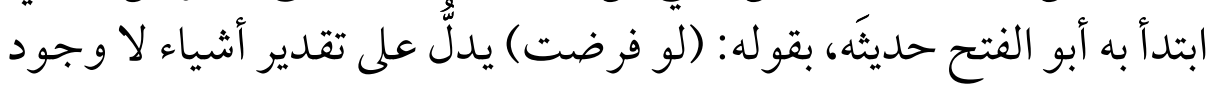

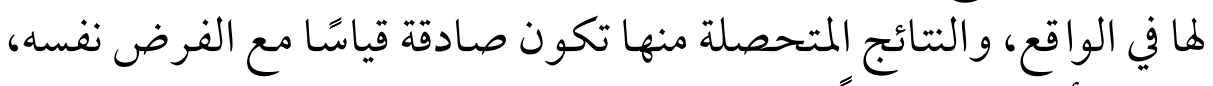

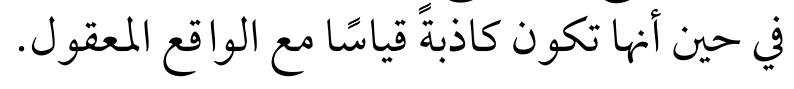

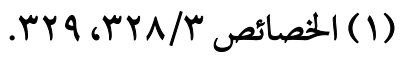

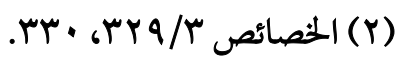
(r) ( الخصائص 


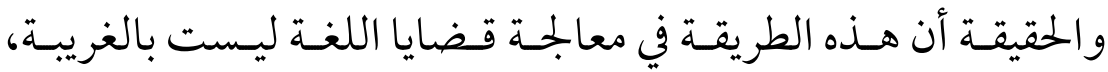

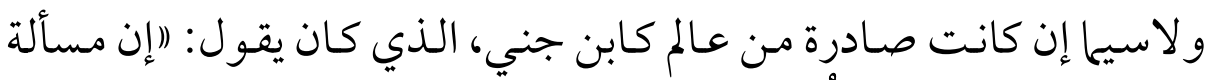

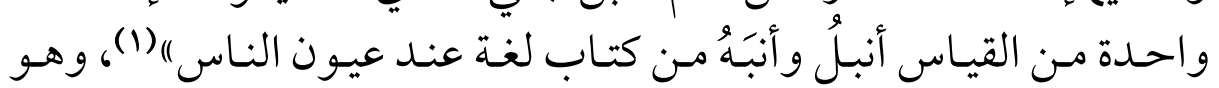

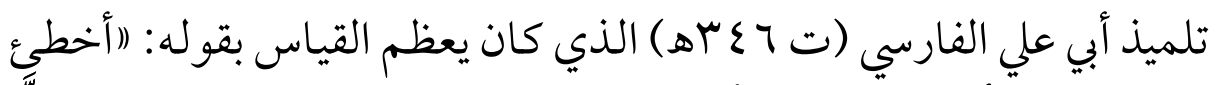

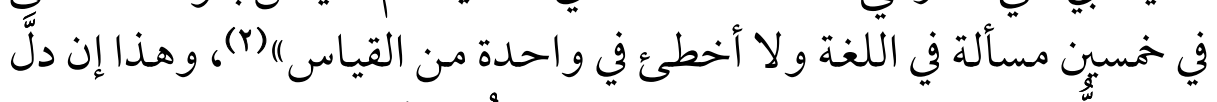

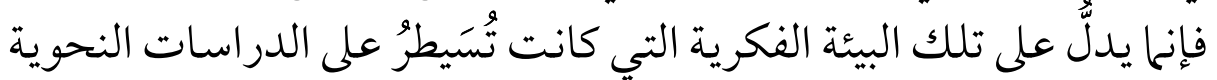

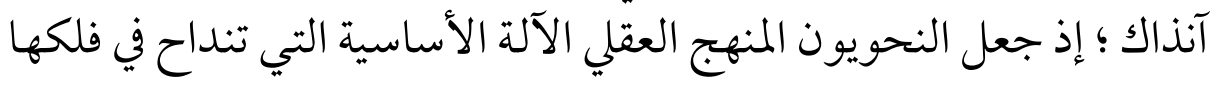

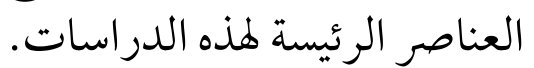

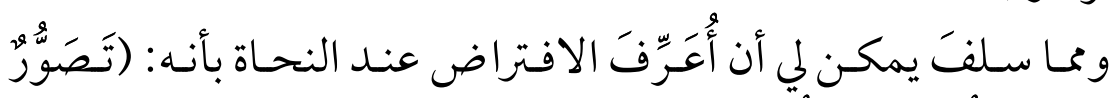

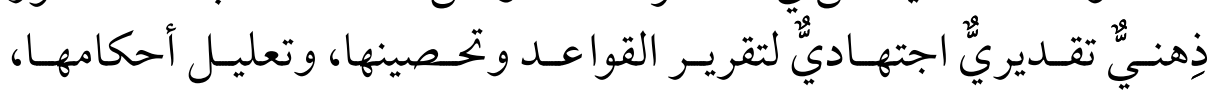

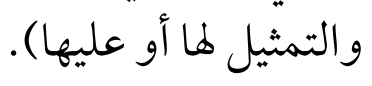

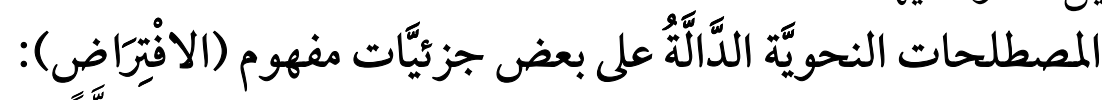

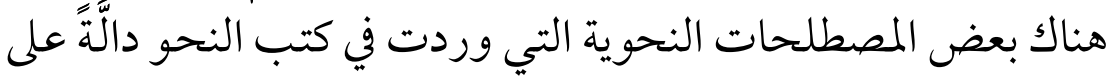
بعض جزئيات مفهوم مصطلح الافتراض، وهي المصلي كالآتي:

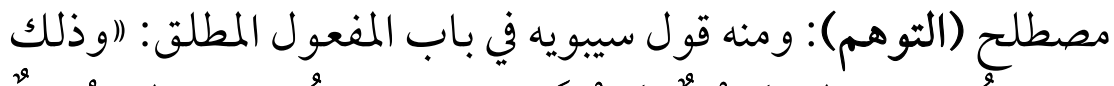

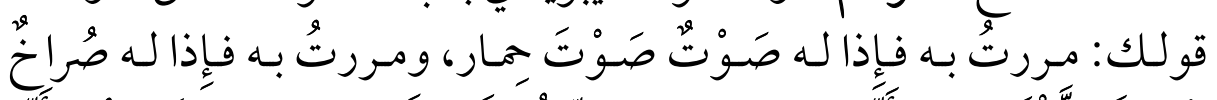

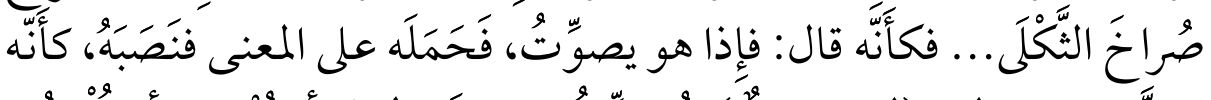

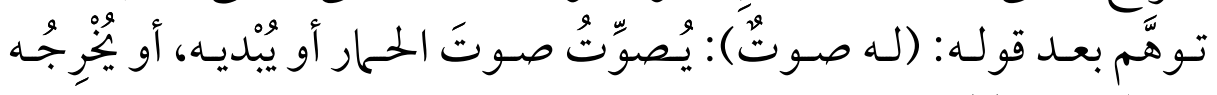

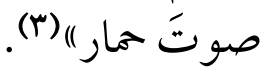

كما نجد في هذا النص نفسه مصطلحًا آخر وهو (الحمل على المعنى المنى)،

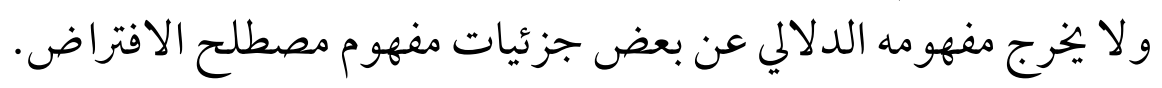

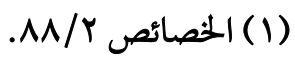

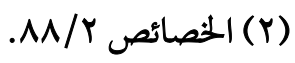
(Y) كتاب سيبويه / (Y) / 
ومنها أيضا مصطلح (التصوُّر)، الذي أشار اليه النحويون كالتوجيه

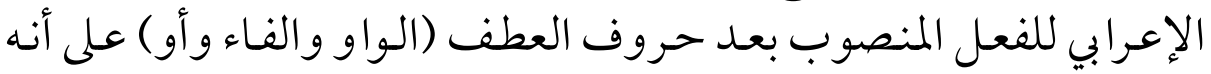

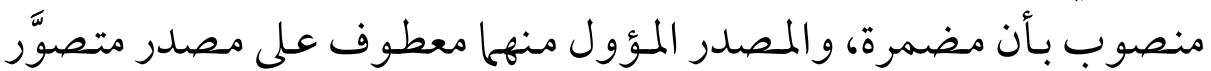

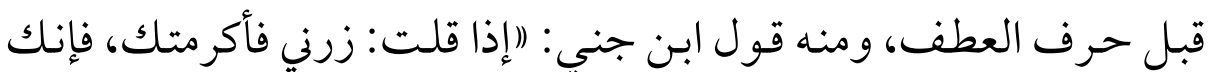

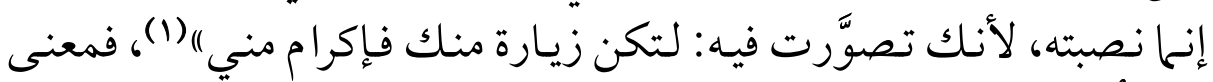

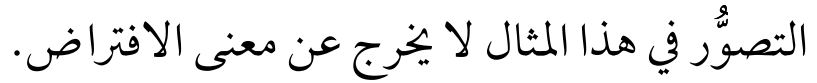

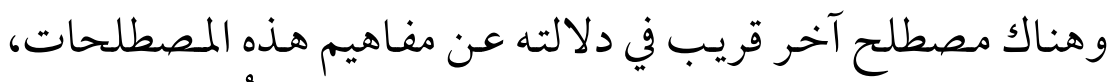

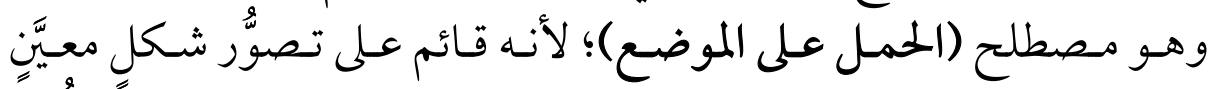

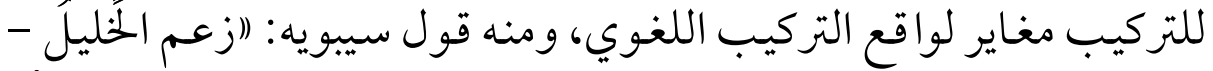

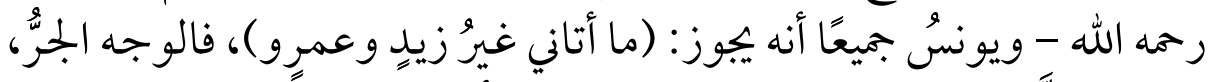

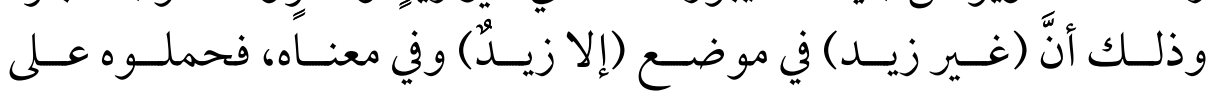

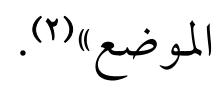

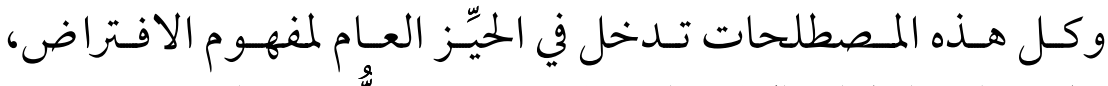

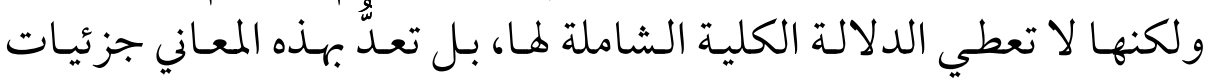

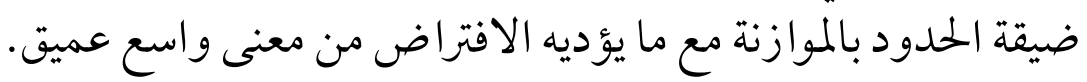




\section{المبحــــ الأول \\ صيغة المهمول هن حيث التهريف والتنيكير بين الافتراض النهوي والهواقع اللغوي هيفي}

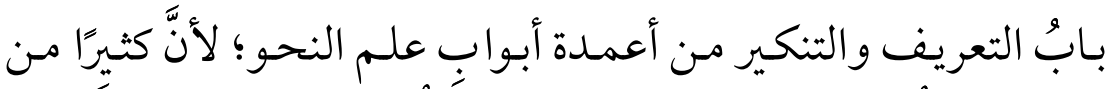

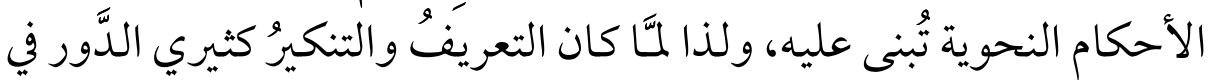

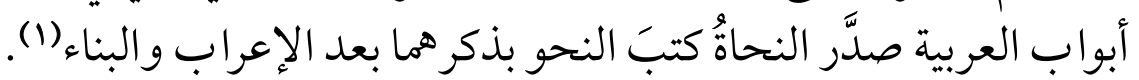

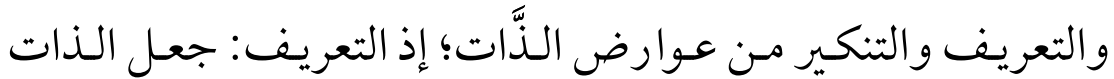

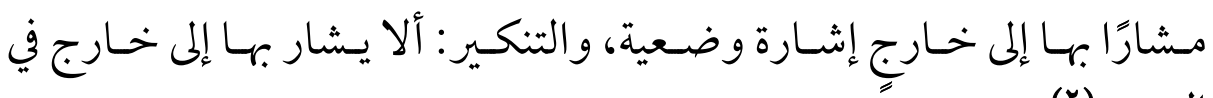

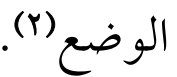

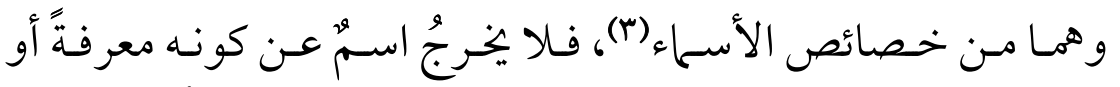

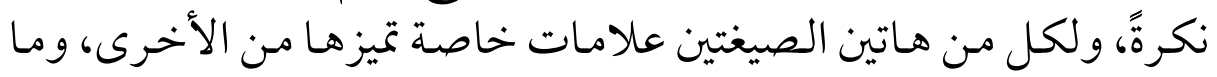

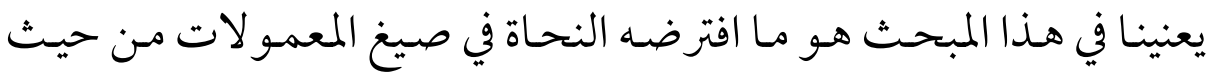

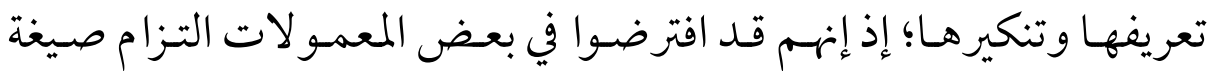

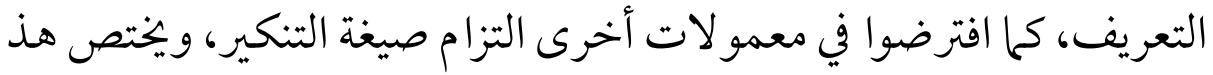

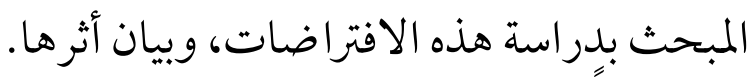

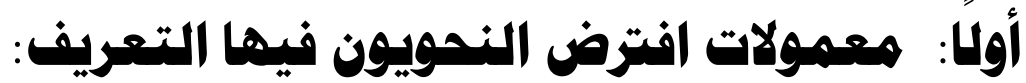

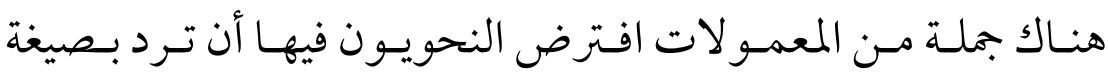

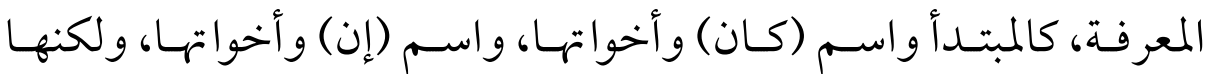

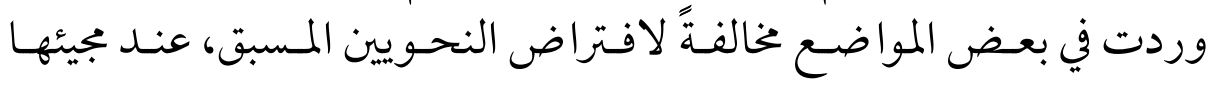

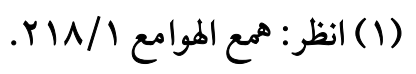

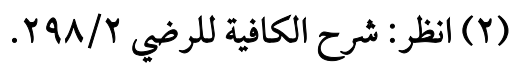

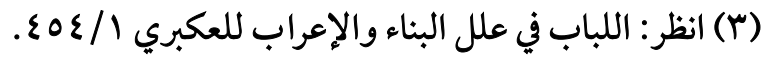


نكــرات، مــا أدى إلى ابتكـار افتراضـاتِ أخـــى حفاظًا عـلى الافتراضـاتِ

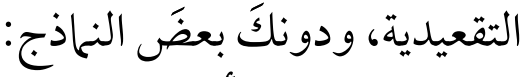

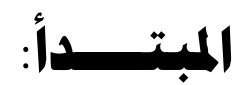

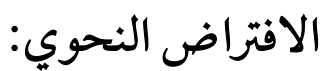

افترض النحويون أن أصل المبتدأ أن يكون مَعرفةًا أو قريبًا منها بوجه النها

من وجوه التخصيصات (1)

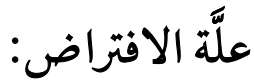

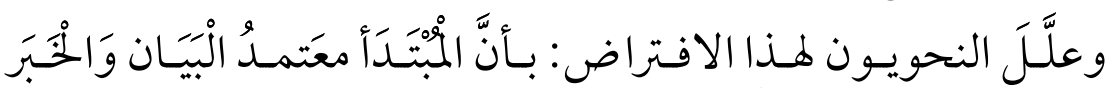

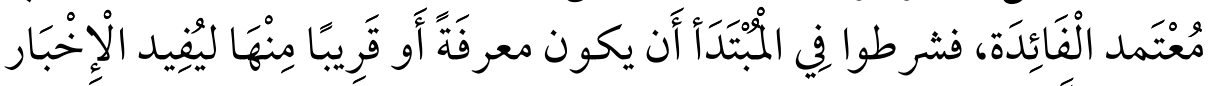

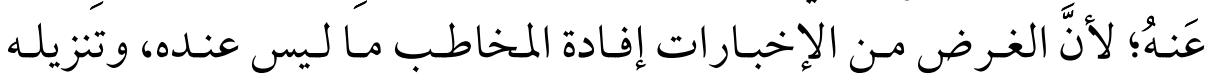

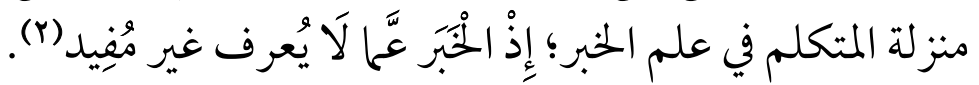

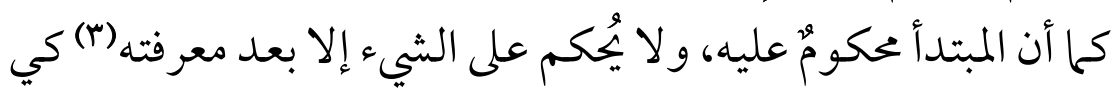

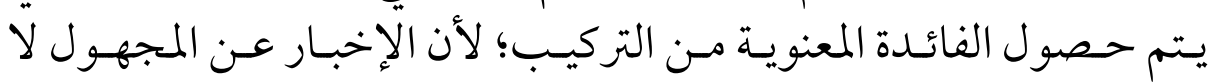

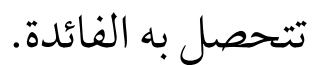

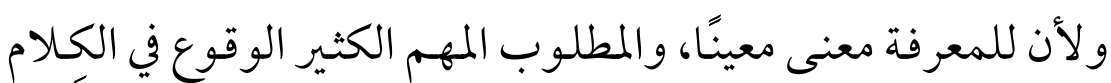

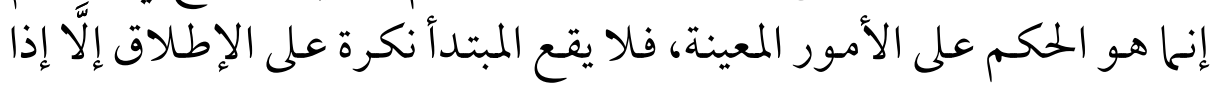

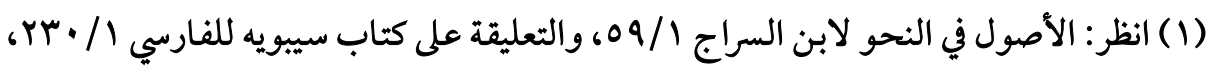

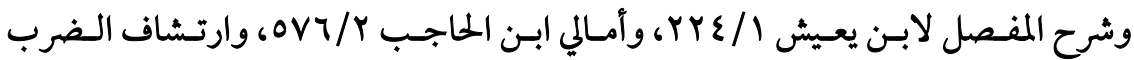

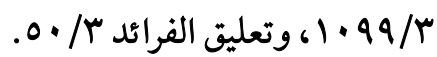

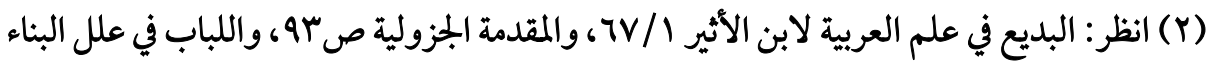

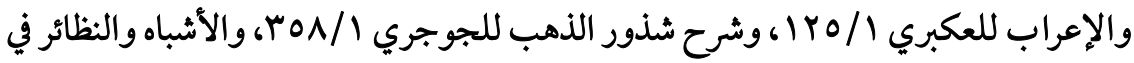

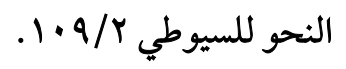

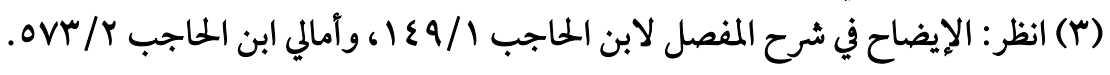


تخصصت تلك النكرة بو جه ما من وجوه التخصيص؛ إذبالتخصيص يقل

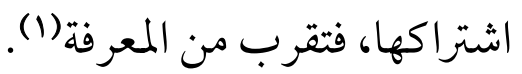

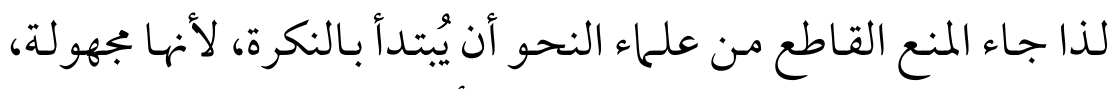

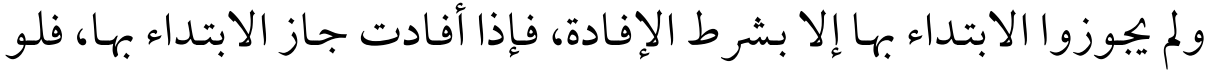

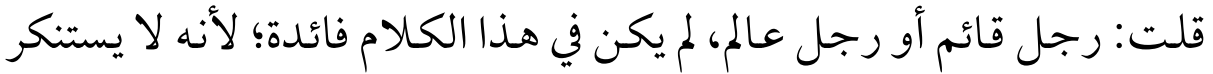

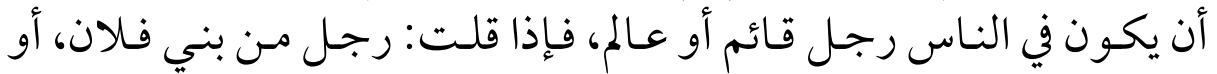

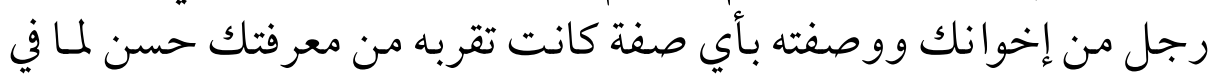
ذلك من الفائدة(r).

وقال ابن هشام: (الم يعول المتقدمون في ضابط ذلك إلا على إنى حصول

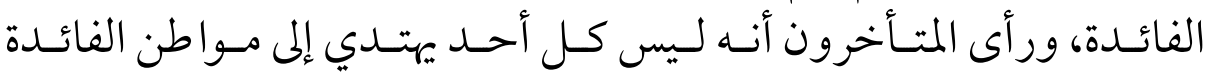

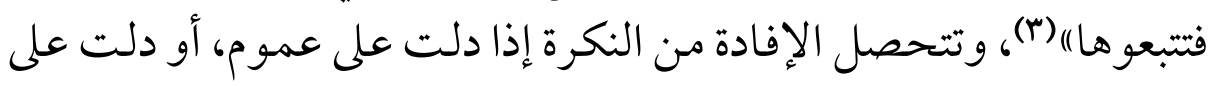

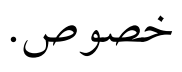
صنيعة النحويين عند خرق الافتراض:

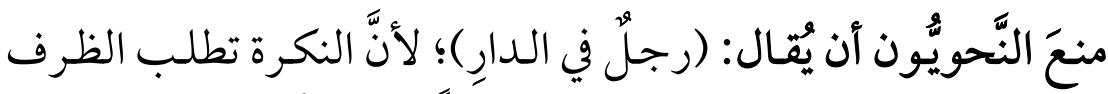

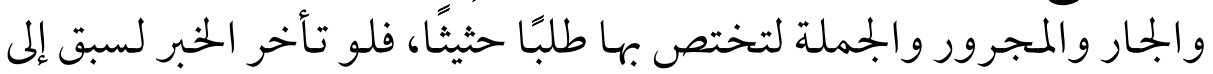

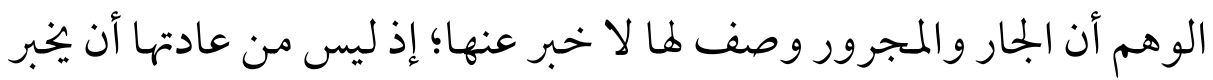

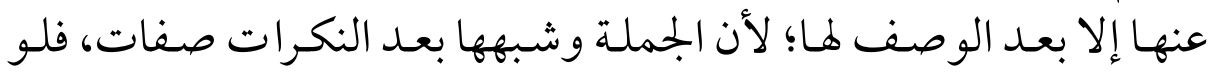

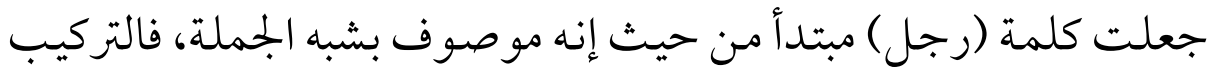

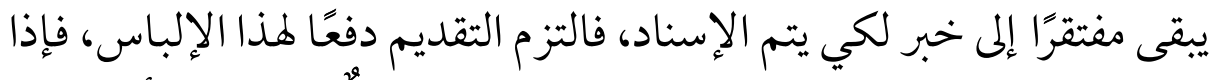

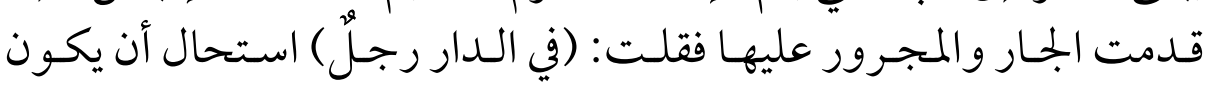

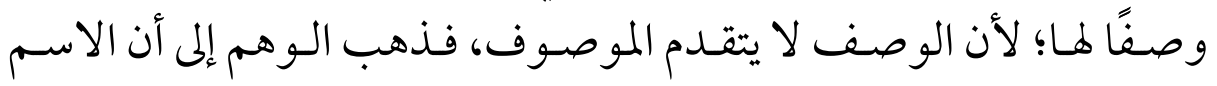

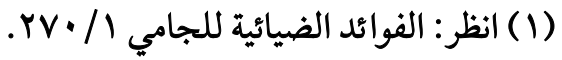

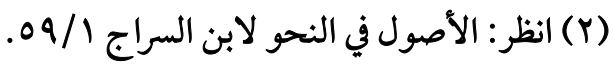

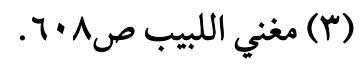


المجرور المعرفة الذي هو في موضع خبر عن النكرة هو المخبر عنه في المعنى وإن كان مجرورًا في اللفظ (1)

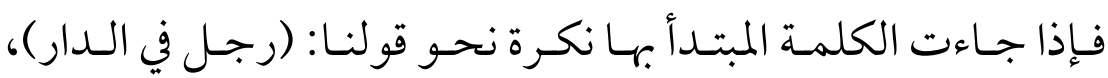

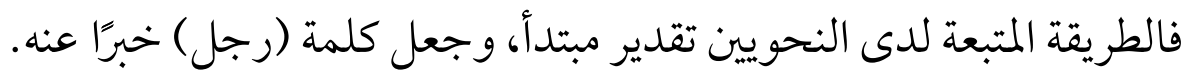

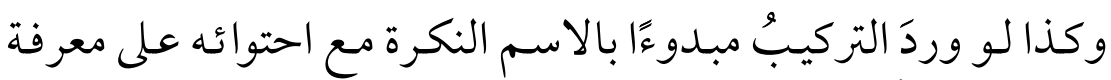

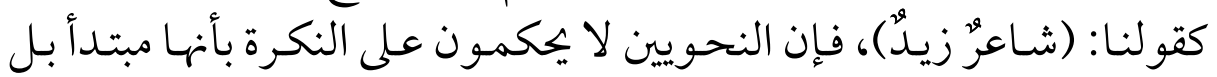

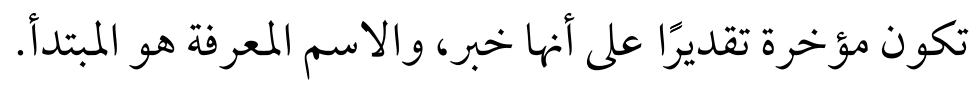

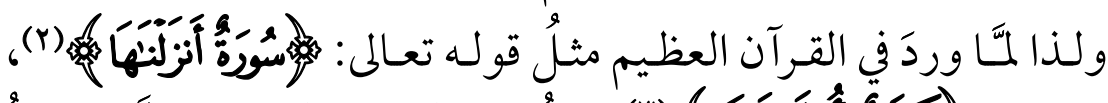

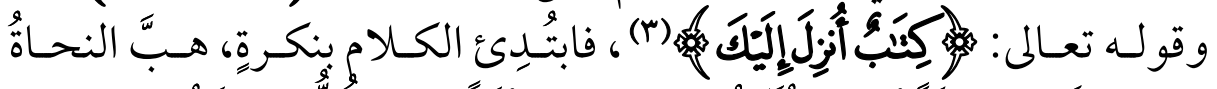

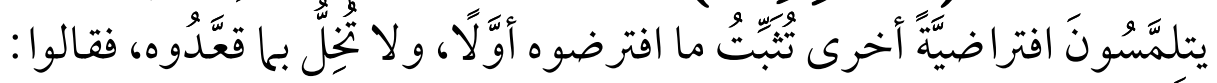

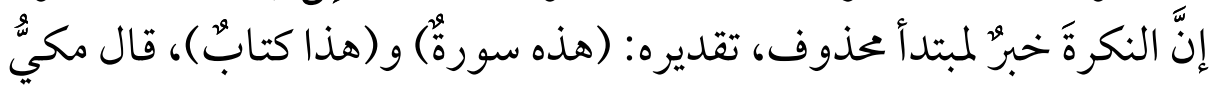

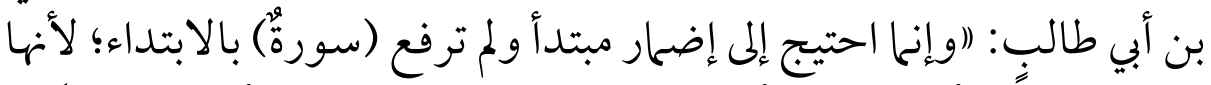

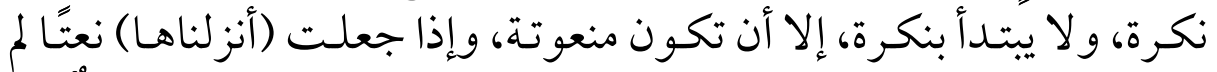

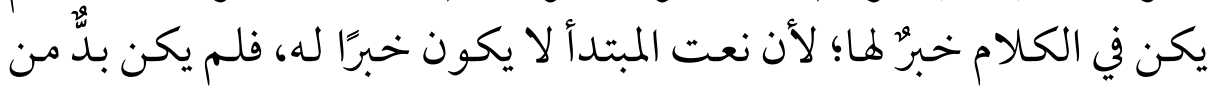

$$
\begin{aligned}
& \text { إضمار مبتدأ ليصح نعت السورة بـ (أنزلناها))(؛(؟). } \\
& \text { رؤية البحث: }
\end{aligned}
$$

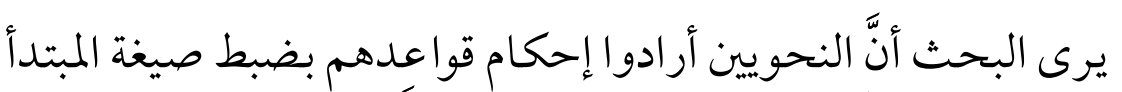

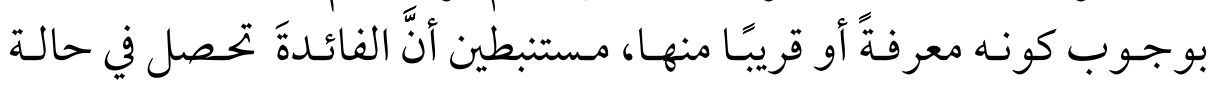

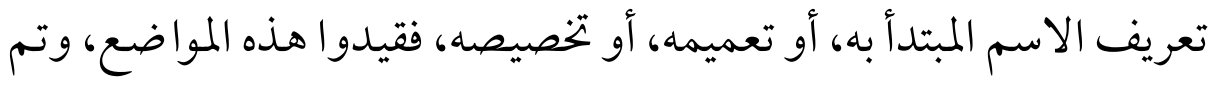
هم بهذا التقييد ترصين القاعدة، واتضاحها.

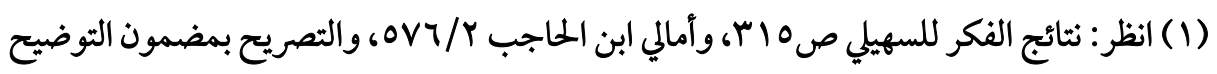
.r19/1

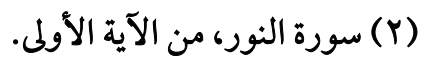

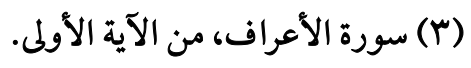

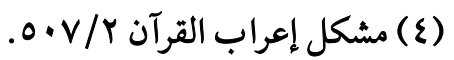


وعليه فإنَّ التقييد من موجبات إتمام فرضية القاعدة النحوية، وحدث التحاث

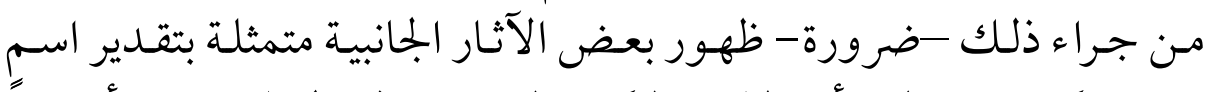

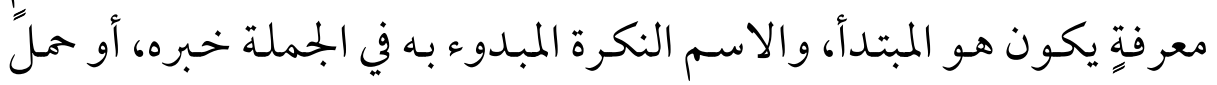

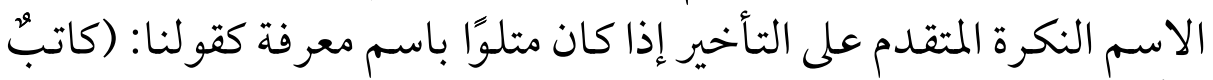
زيدُ)؛ لتسلم بذلك قاعدتهم.

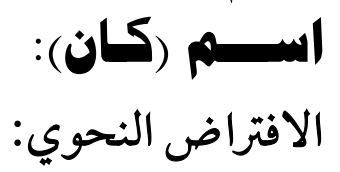

$$
\text { افترض النحويون أن اسم (كان) يجب أن يكون معرفة. }
$$

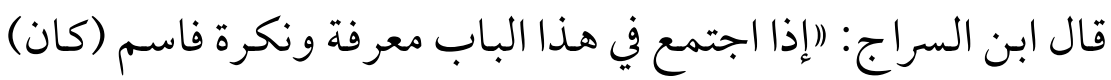

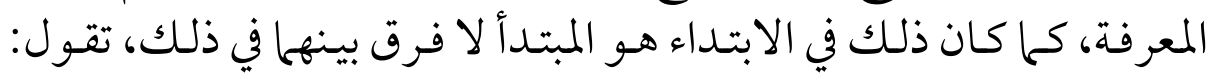

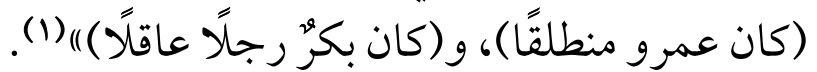

$$
\begin{aligned}
& \text { علَّة الافتراض: ع عنط: }
\end{aligned}
$$

علَّلَ سيبو يه لهذا الافتراض اضفي في (باب الفعل الذي يتعدى اسم الفاعل

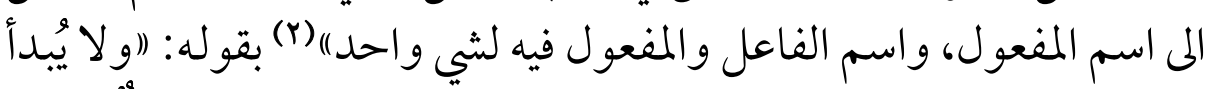

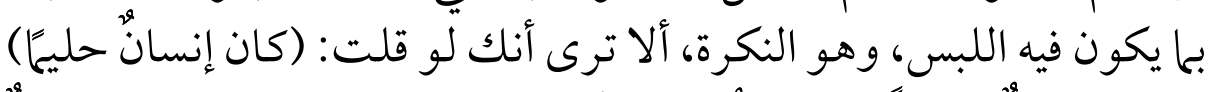

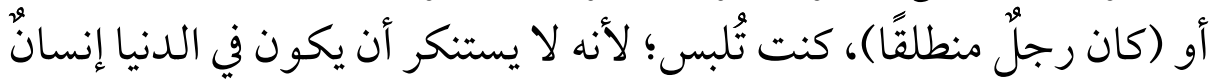

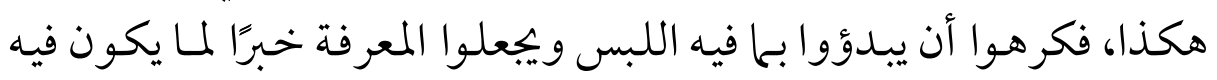

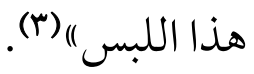

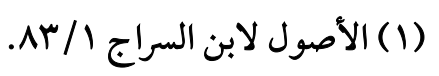

(Y) يقصد الأفعال الناقصة.

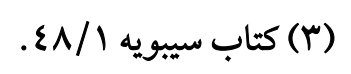




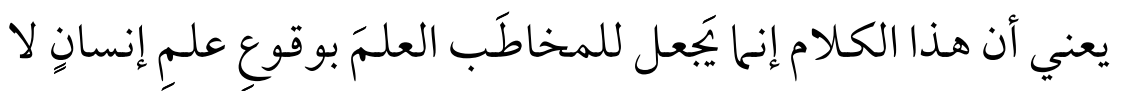

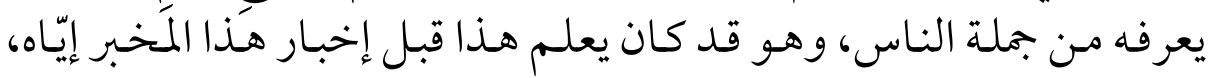

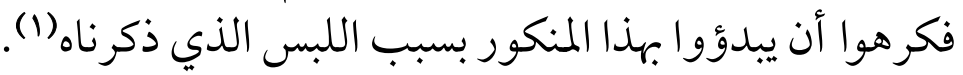

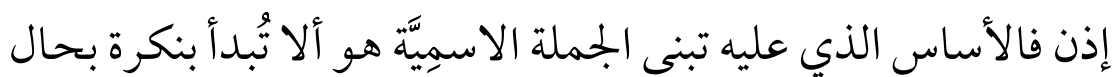

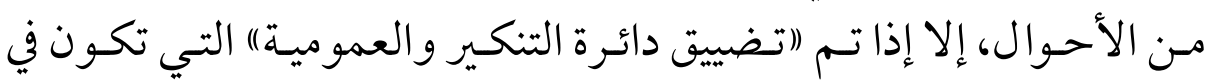

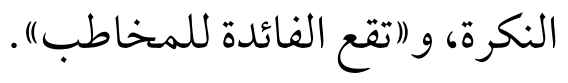

\section{صنيعة النحويين عند خرق الافتراض:}

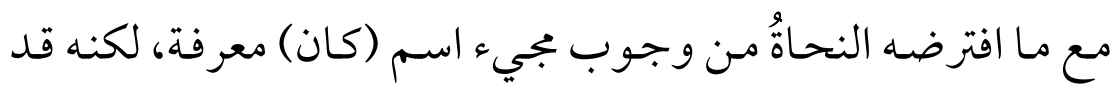

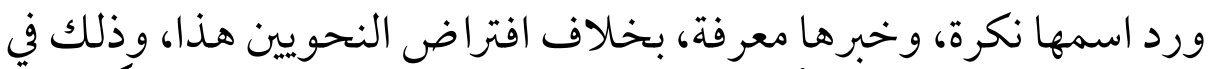

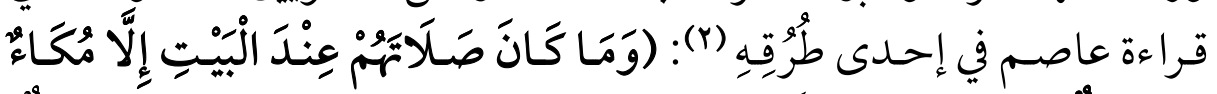

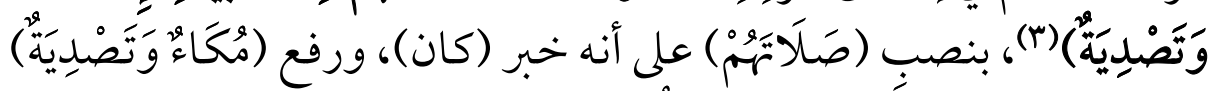

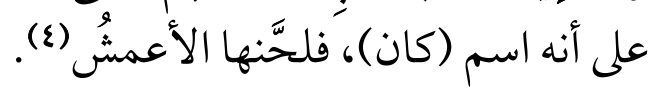

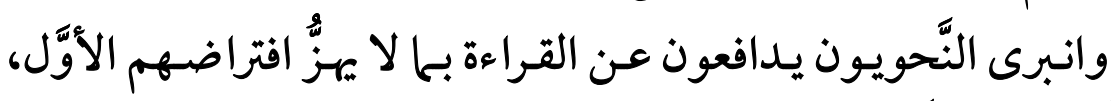

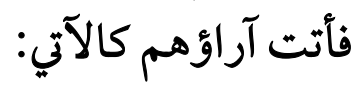

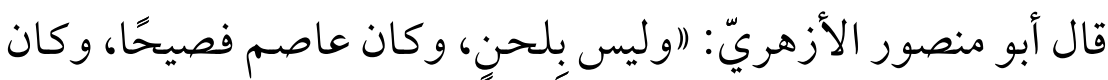

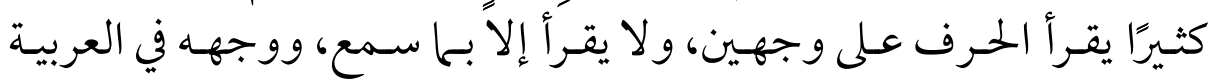
صحيح") (0)

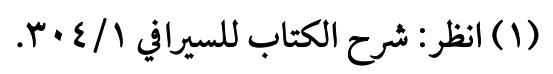

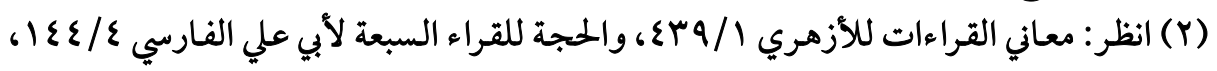

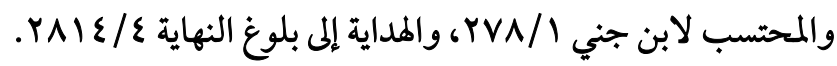

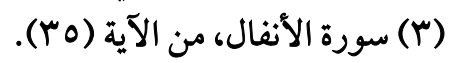

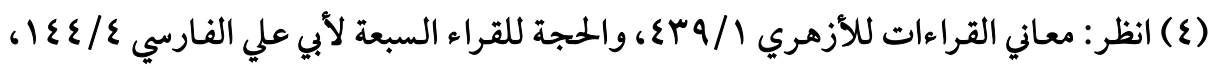

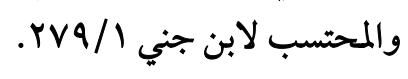

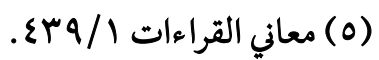




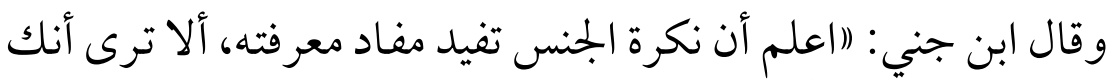

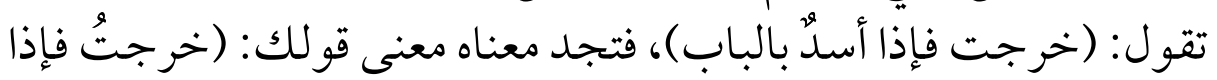

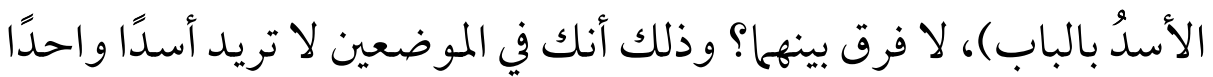

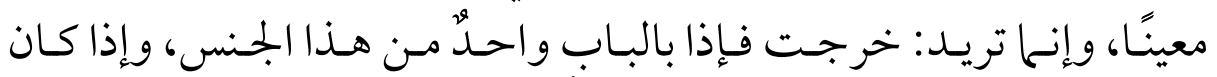

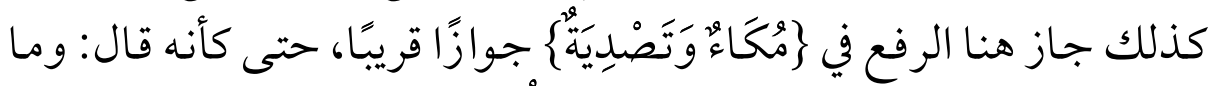

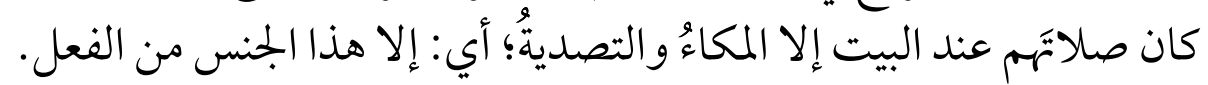

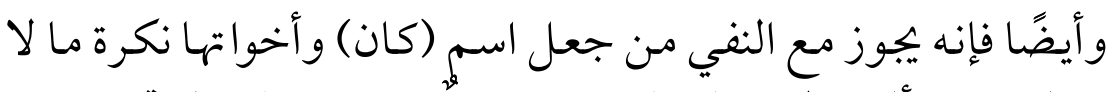

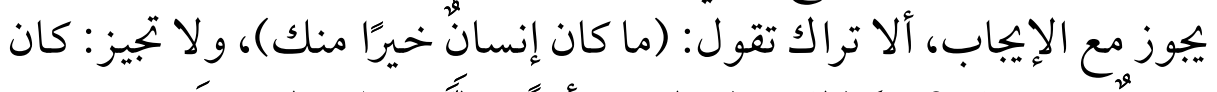

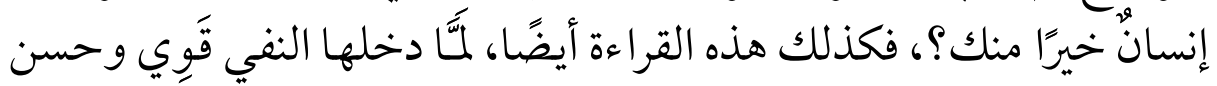

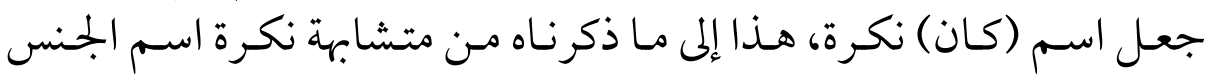
لمعرفته (1) (1)

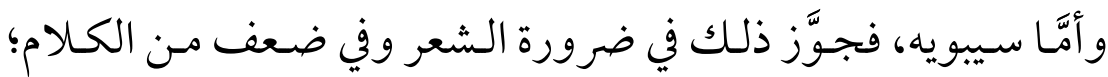

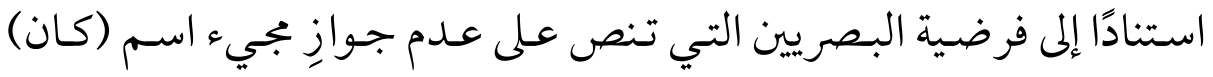

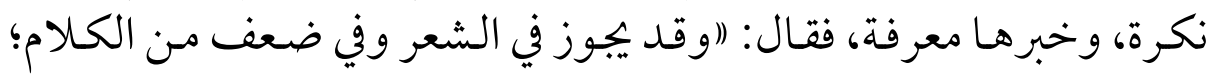

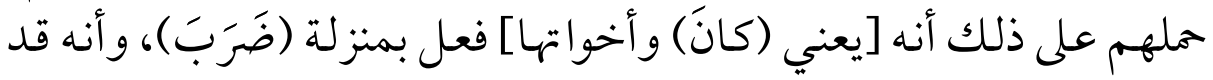

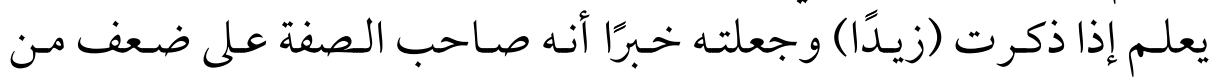

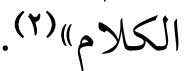

واستشهد إمامُ النحاة على ذلك بشوا هد، منها: قول خِداش بن زهير:

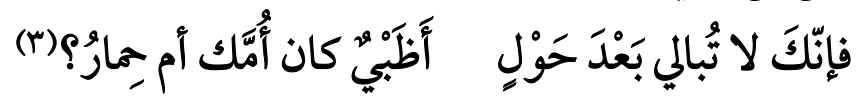

$$
\begin{aligned}
& \text { (1) المحتسب IVQ/Y (Y (Y) } \\
& \text { (Y) كتاب سيبويه / (Y) (Y) }
\end{aligned}
$$

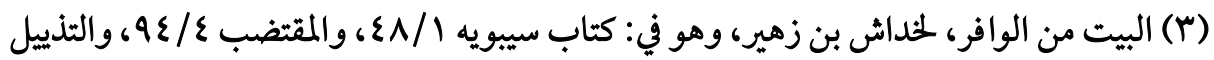

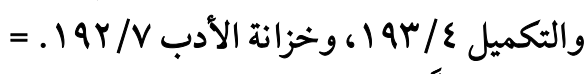

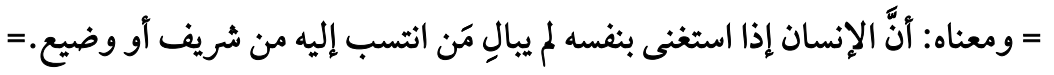




$$
\text { وقول حسان بن ثابت: }
$$

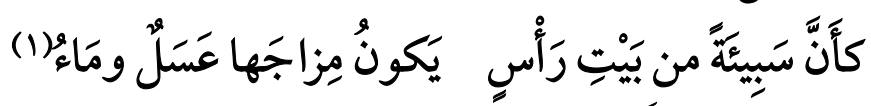

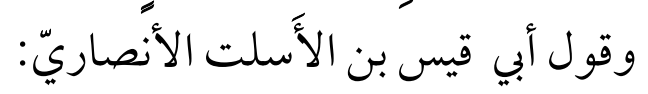

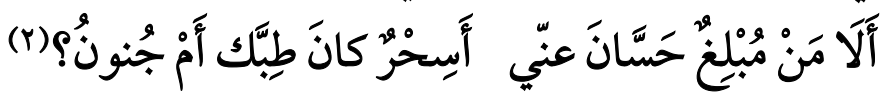

$$
\text { إلى غير ذلك مما ذكر سيبويه. }
$$

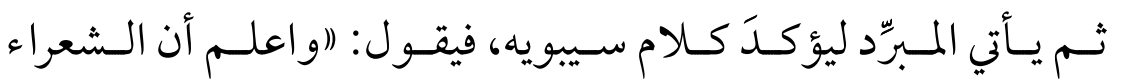

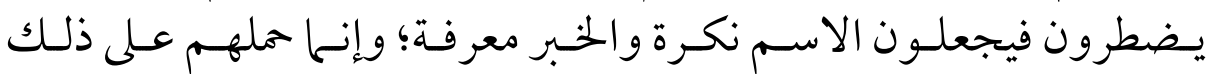

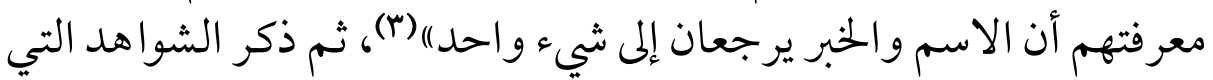

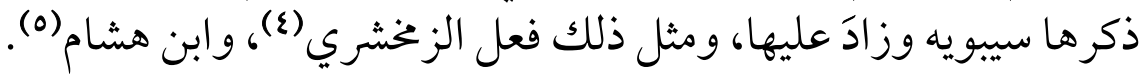

= و والشاهد فيه قوله: ( أظبي كان أمك أم حمار؟)؛ حيث جاء اسم (كان) نكرة وخبرها معرفة، وذلك ييوز في الشعر فقط عند سيبويه.

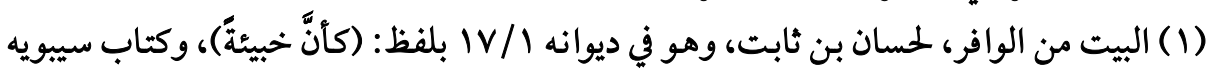

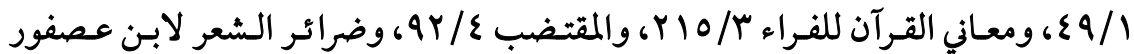

$$
\text { ص }
$$

$$
\text { والسبيئة: الخمر، وبيت رأس: بلدة في الثام معروفة بالخمر. }
$$

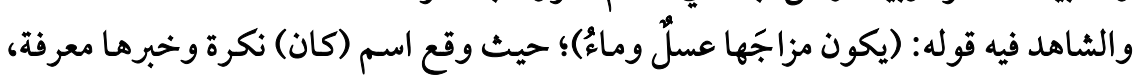

$$
\text { وذلك للضرورة عند سيبويه والمبرد. }
$$

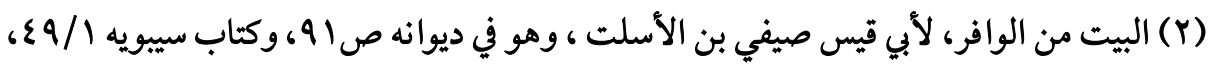

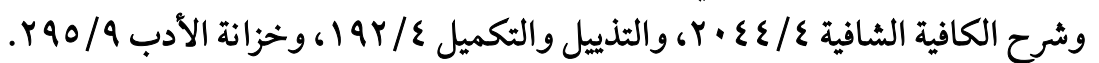

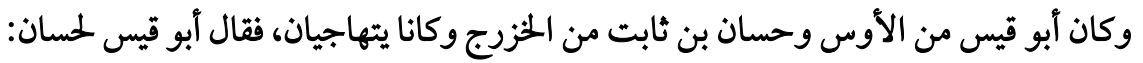

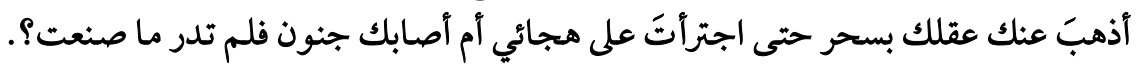

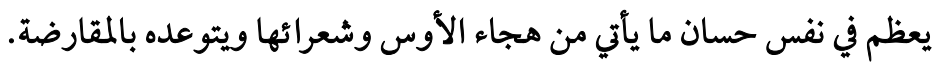
والشاهد فيه كسابقيه.

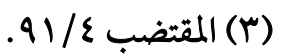

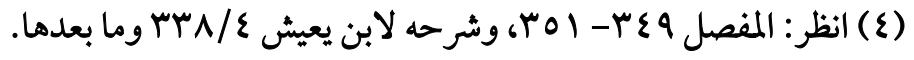

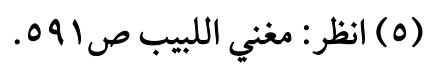


و أمَّا ابن مالك فذهب إلى جواز أن يكون الاسم نكرة والخبر معرفة في

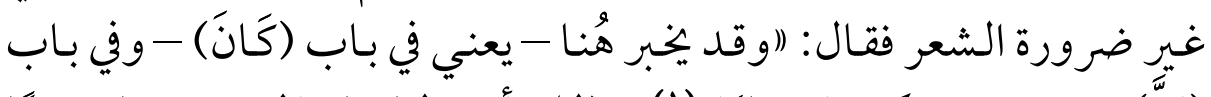

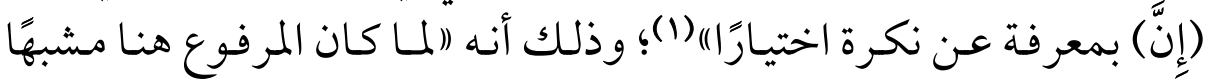

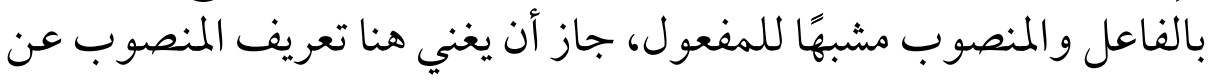

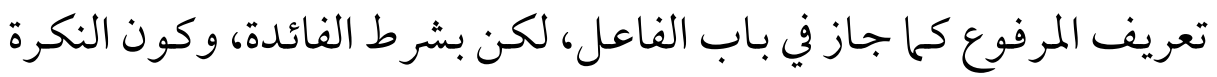
غير محضة|(r) (r)

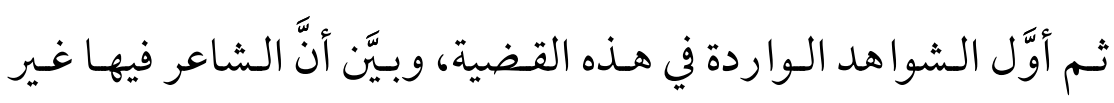
مضطر في جعل الاسم نكرة والخبر معرفة الثران.

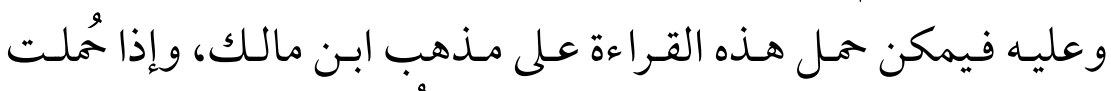

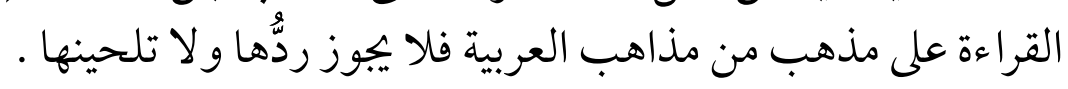

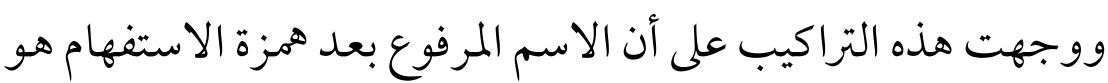

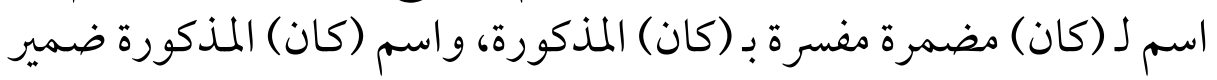

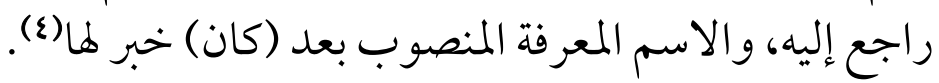

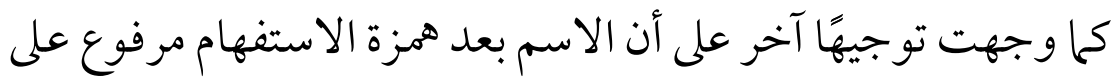

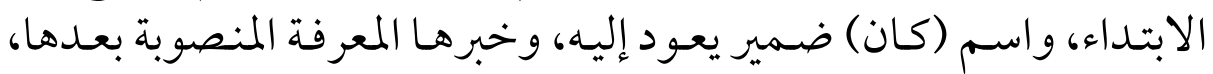

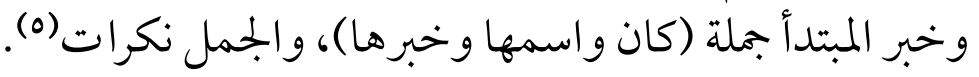

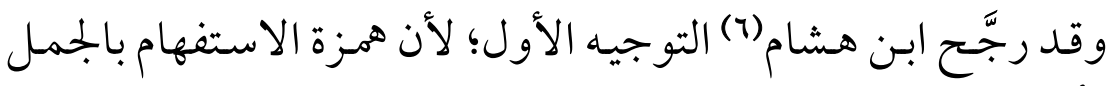

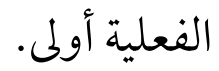

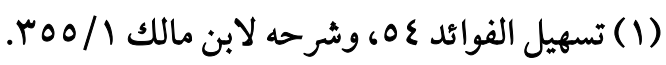

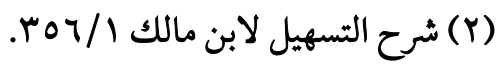

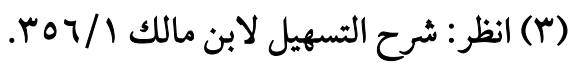

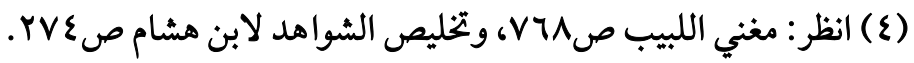

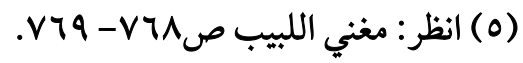

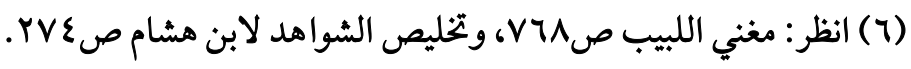




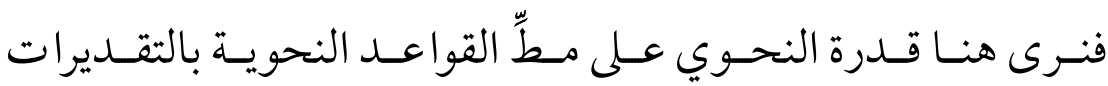

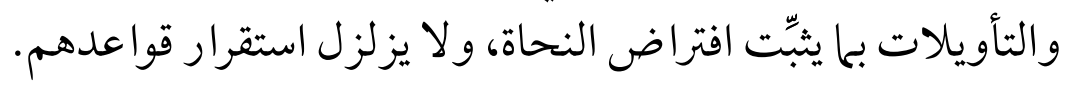

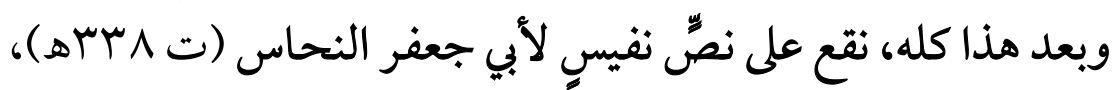

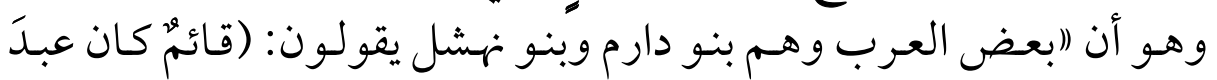

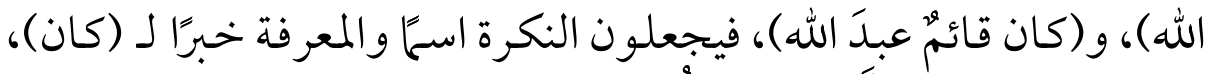

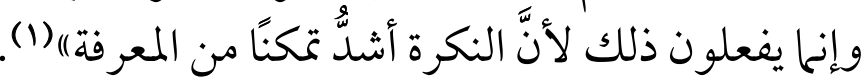

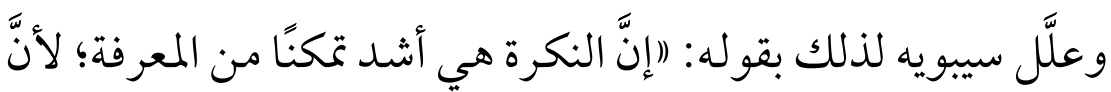

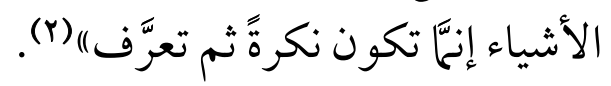

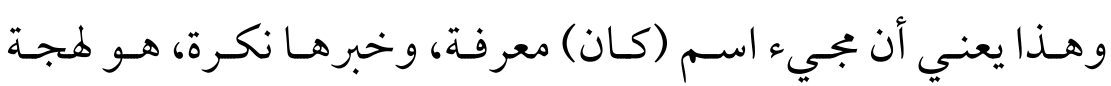

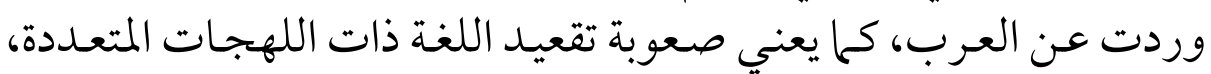

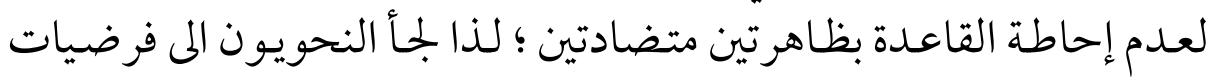
تخريج إحدى هاتين الظاهرتين، لتطرد القاعدة فيها.

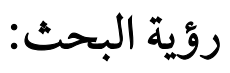

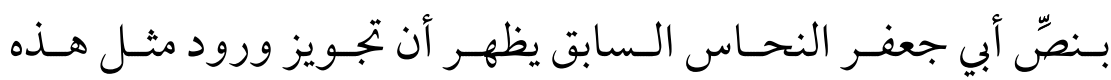

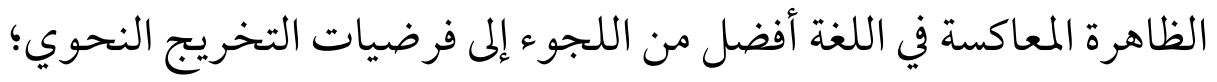

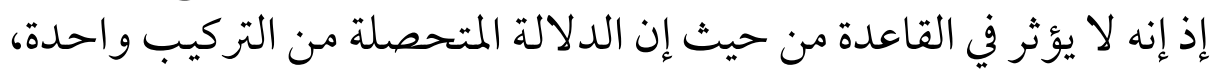

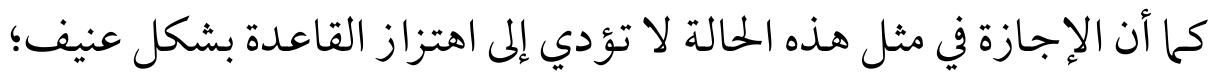

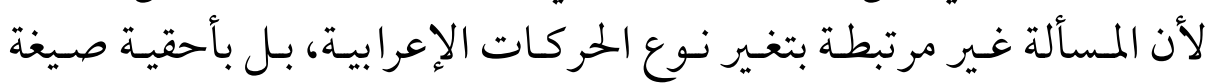

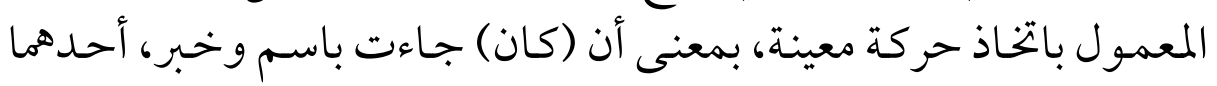

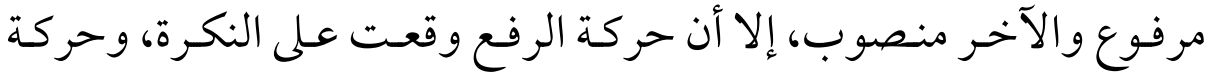

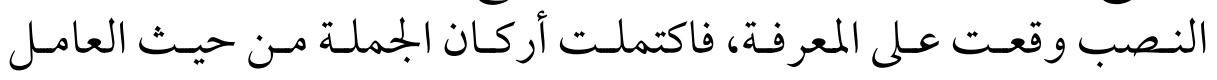

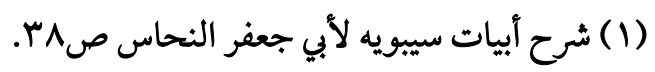

$$
\begin{aligned}
& \text { (Y) كتاب سيبويه T/T) }
\end{aligned}
$$




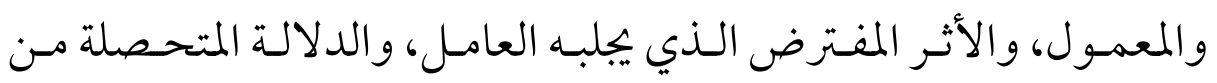

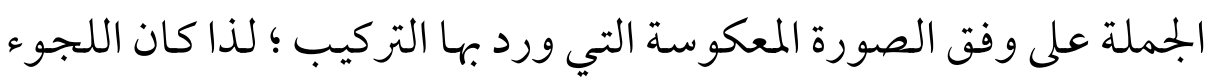
إلى الإجازة أفضل طريق لمعالجة مثل هذه التراكيب.

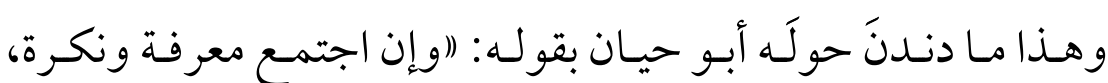

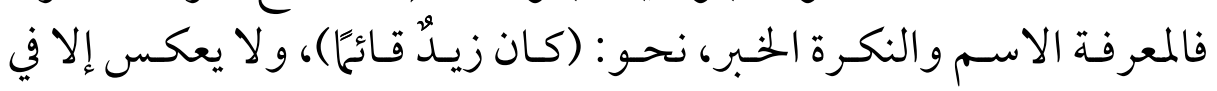

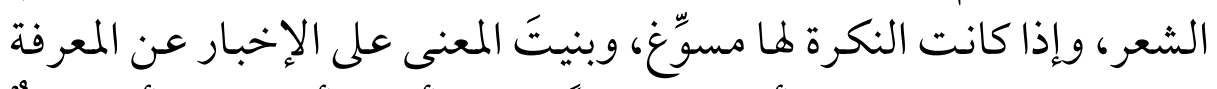

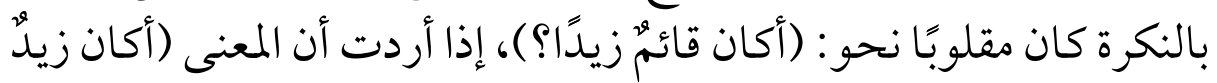

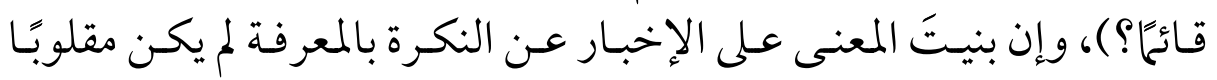

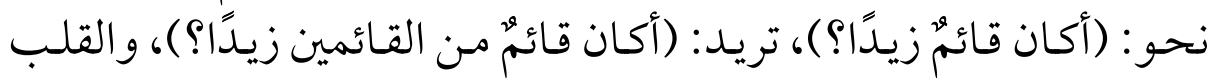

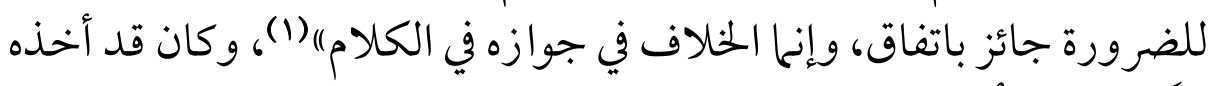

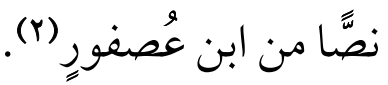




\section{ثانيًا: همهمولات افتزض النمويون فيهها التنـير:}

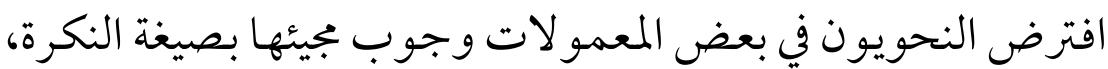

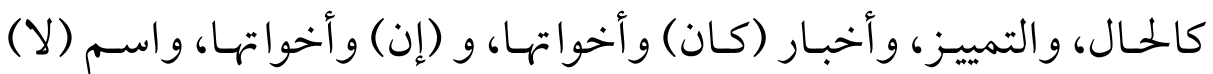

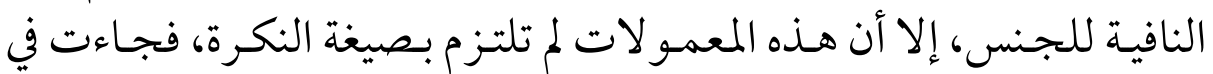

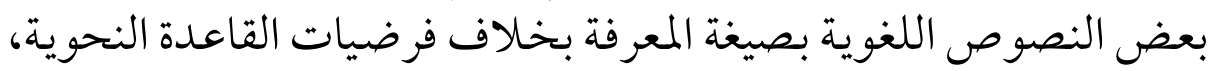

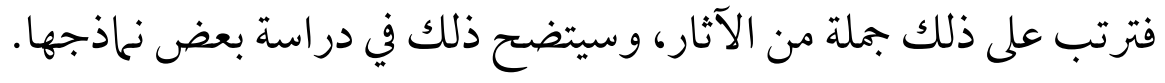

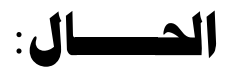

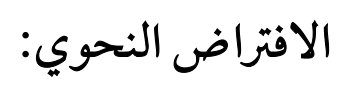

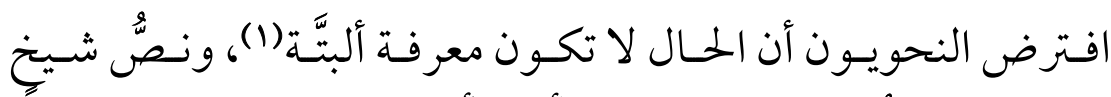

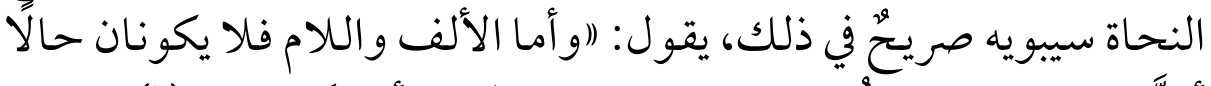

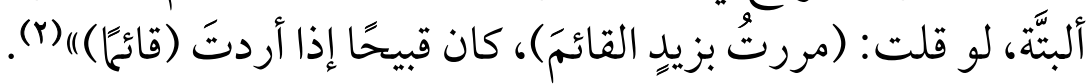

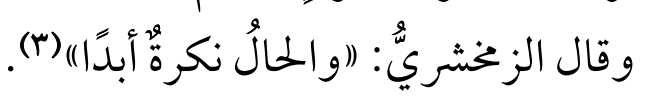

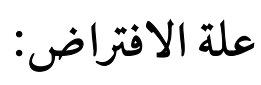

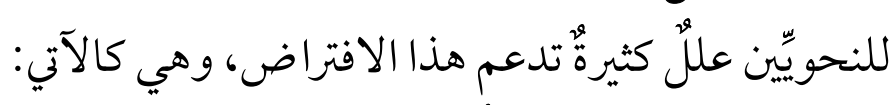

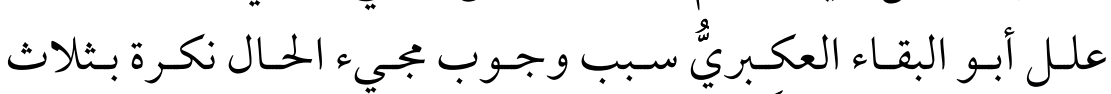

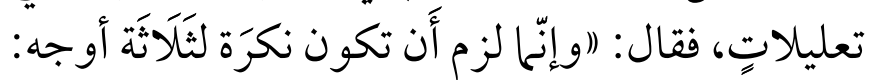

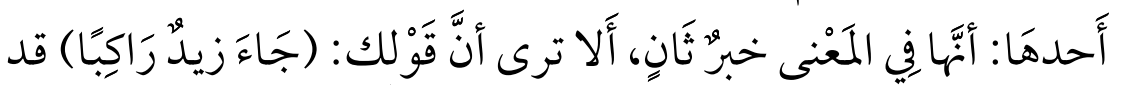

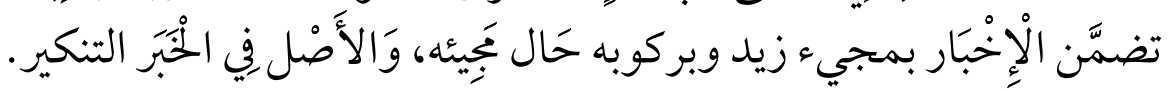

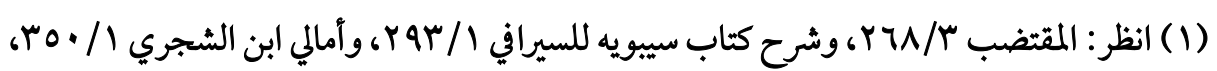

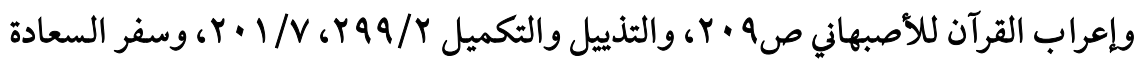

$$
.0\{7 / r
$$

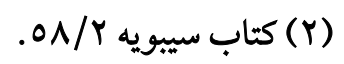

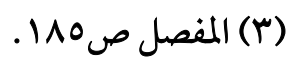




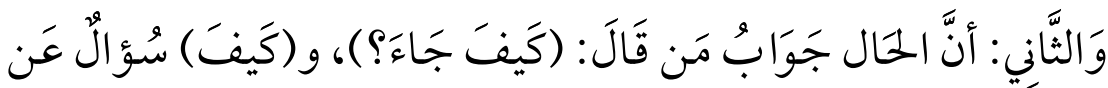

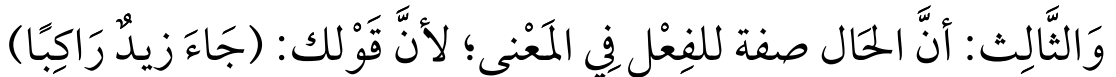

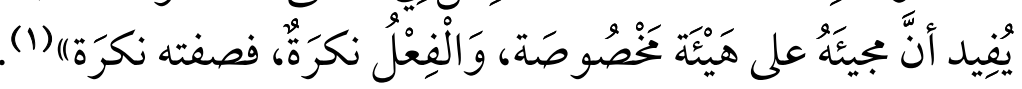

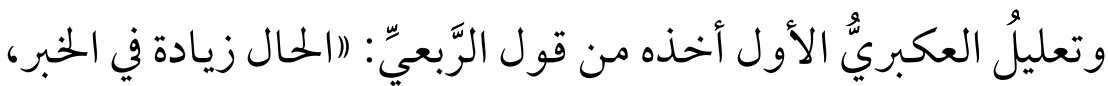

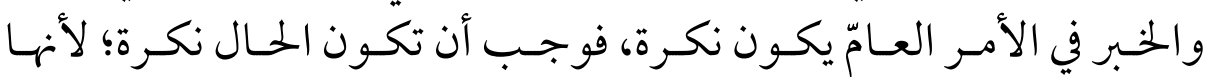

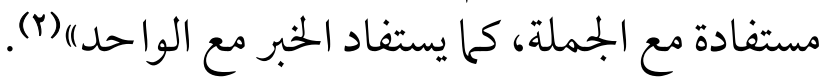

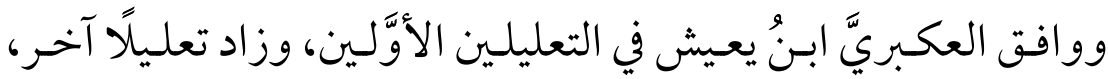

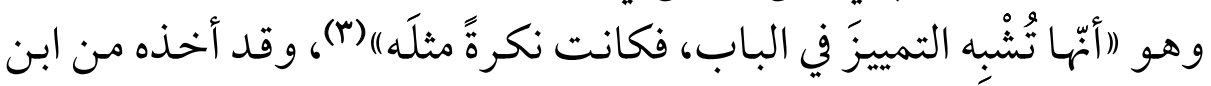

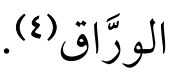

وو افقَّ العكبريَّ أبو البركات الأنباريُّ في تعليله الثالث(ه).

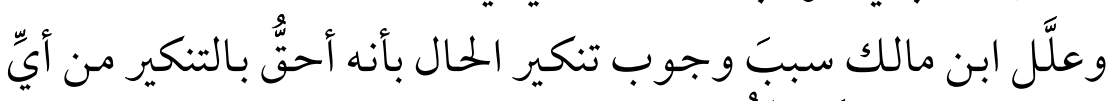

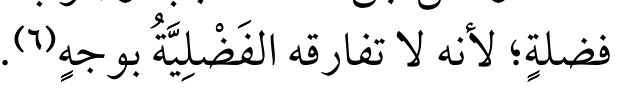

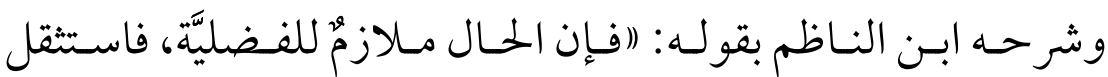

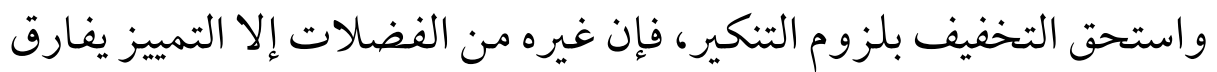

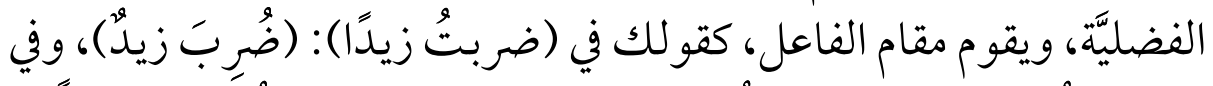

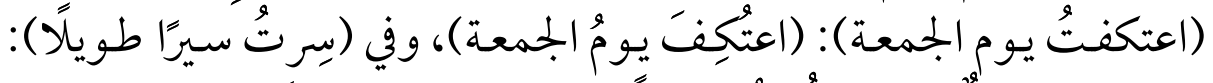

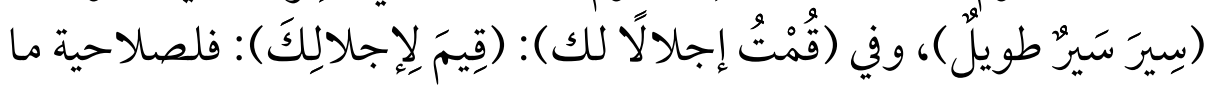

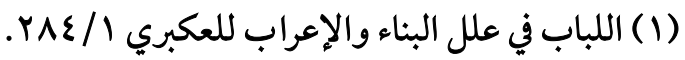

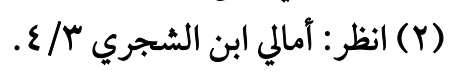

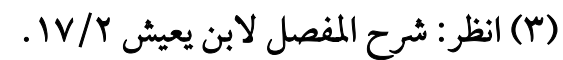

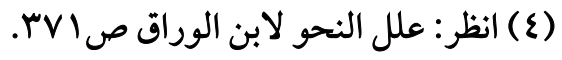

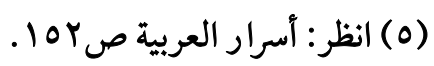

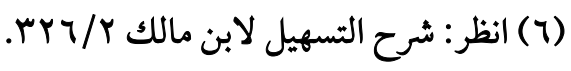


سوى الحال و التمييز من الفضلات لصيرورته عمدة جاز تعريفه، بخلاف (الحال والتمييز (1)

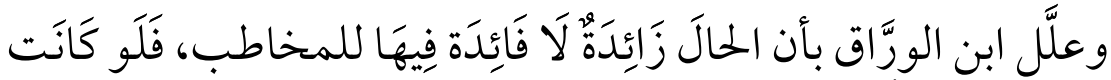

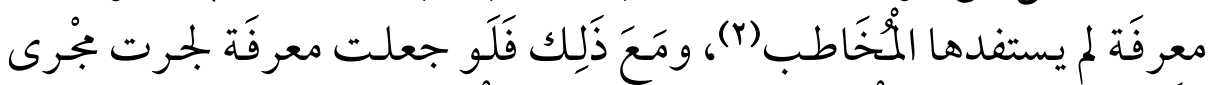

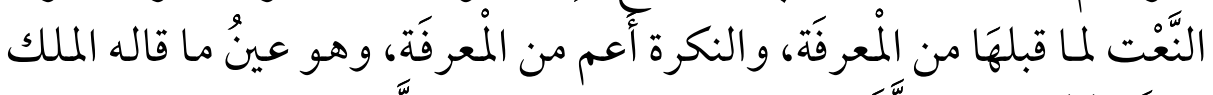

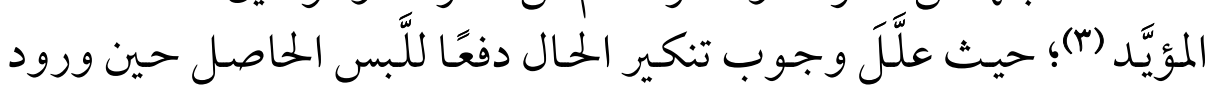

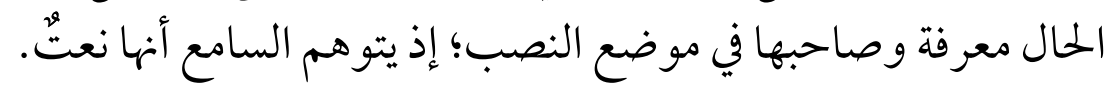

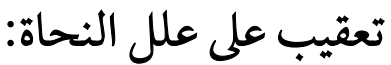

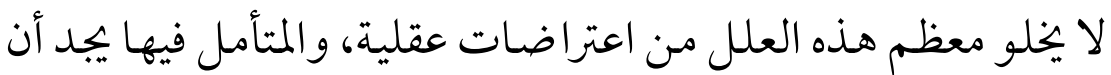
معظمها لا يتصف بالقوة، ولا يصمد أمام البحث.

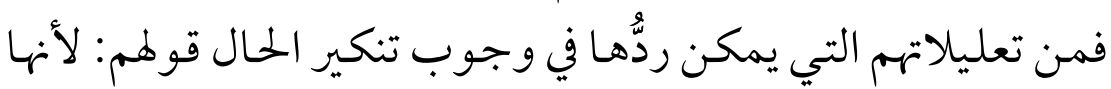

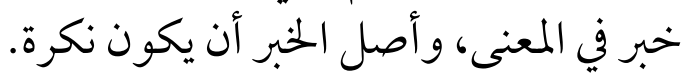

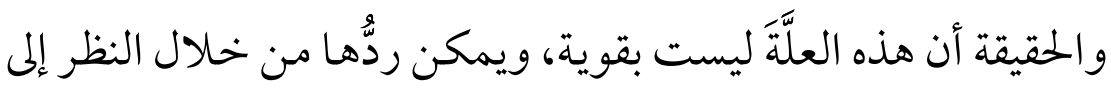

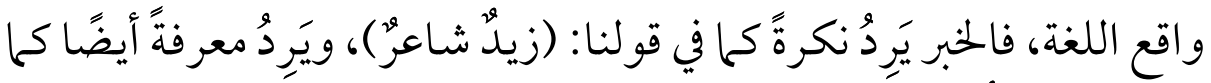

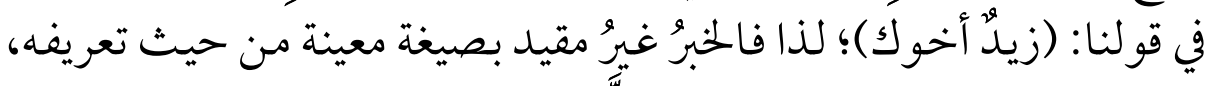
وتنكيره، وبذلك يتم انتقاض هذه العِلَّة.

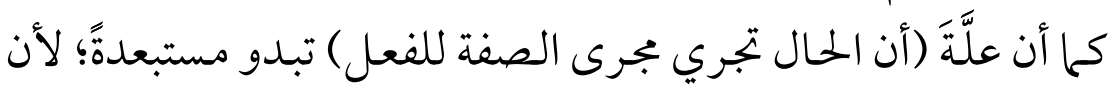

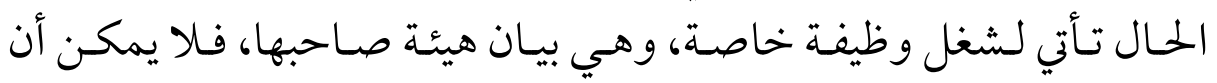
تشغل وظيفتين في آن واحد.

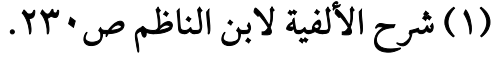

$$
\begin{aligned}
& \text { (Y) انظر: علل النحو ص النئ. }
\end{aligned}
$$

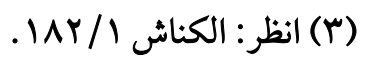




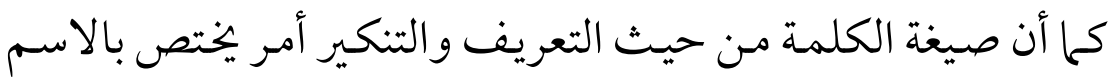

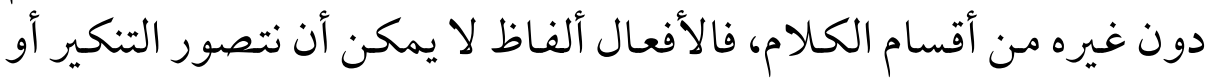

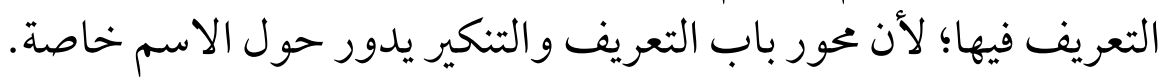

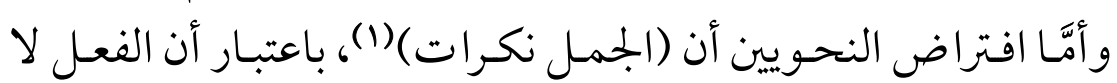

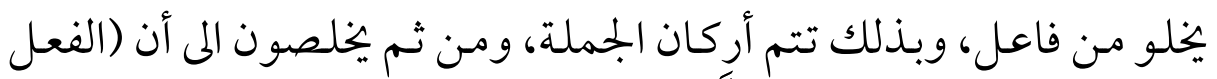

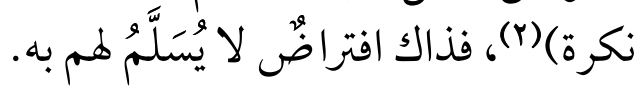

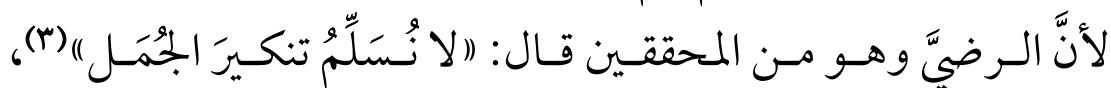

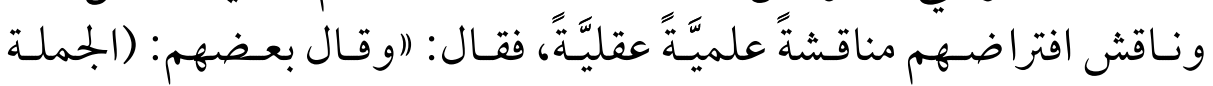

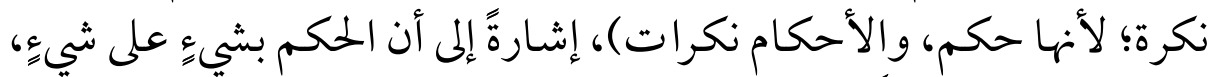

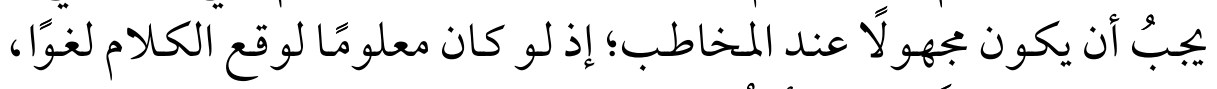
نحو: (السماءُ فوقَنا)، و والأرضُّ تحتَنَا).

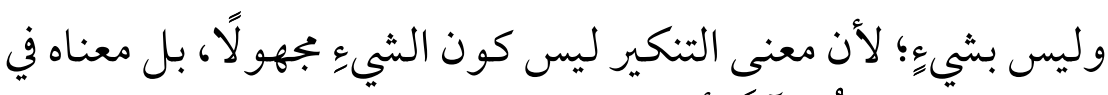

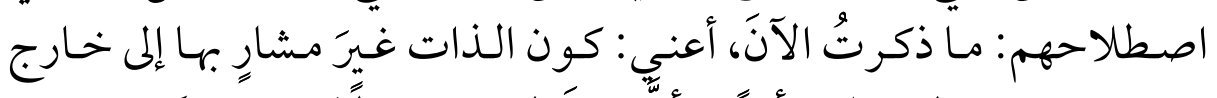

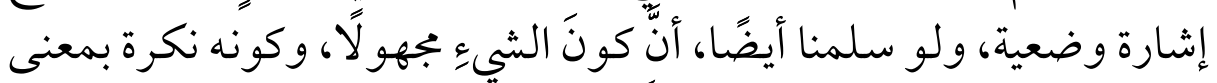

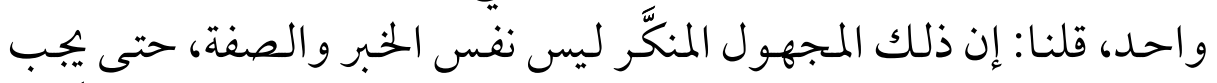

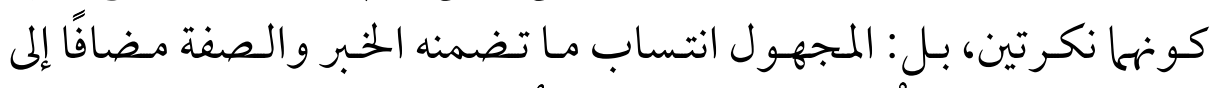

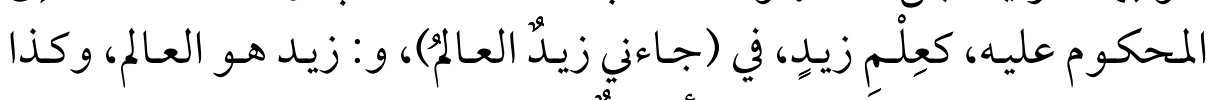

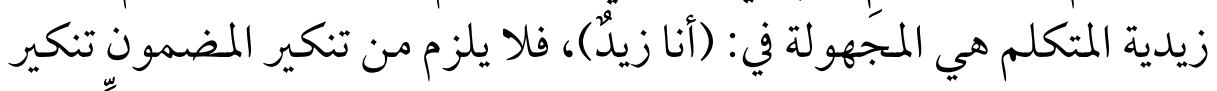

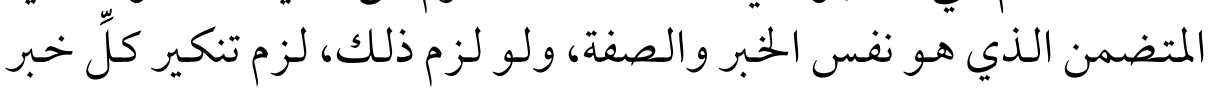

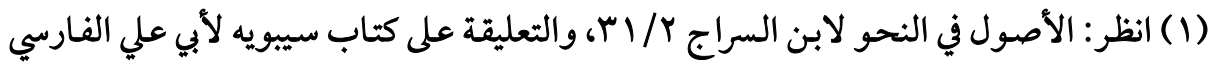

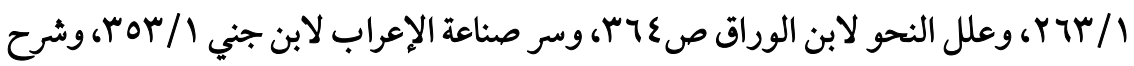

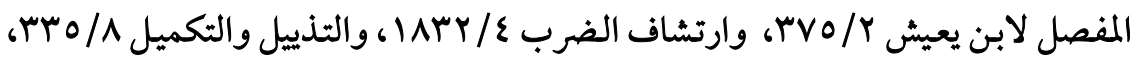

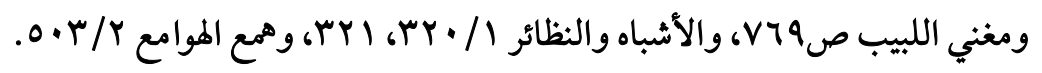

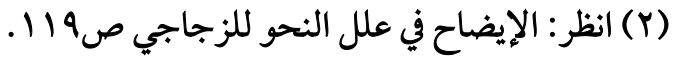

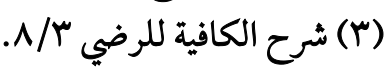




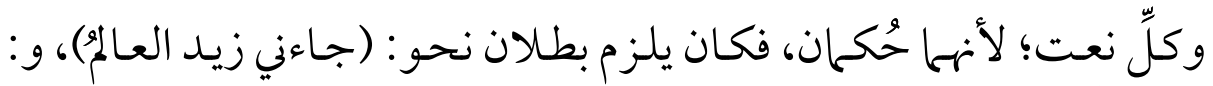

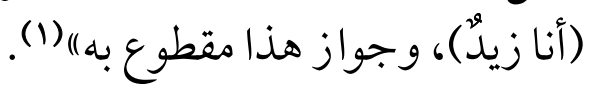

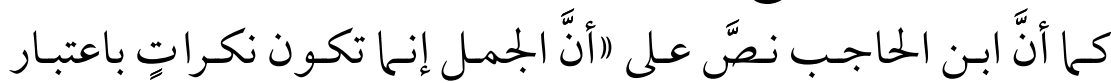

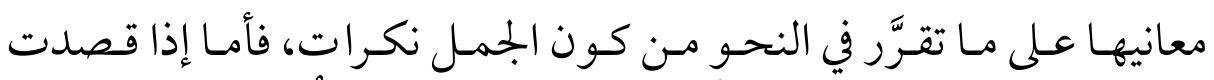

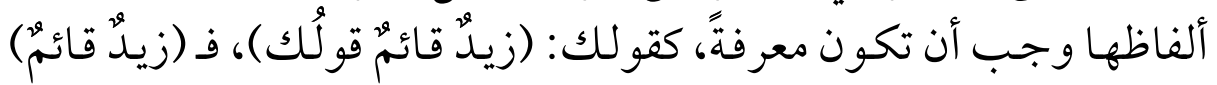

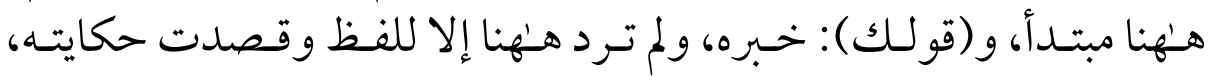

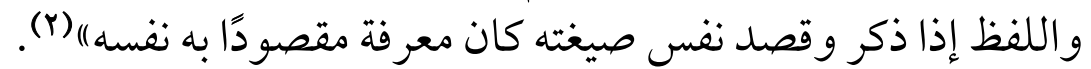

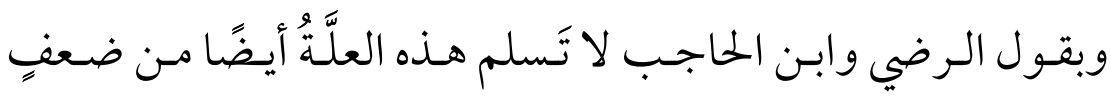

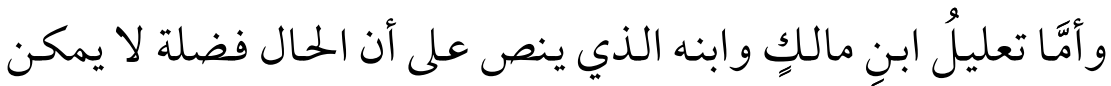

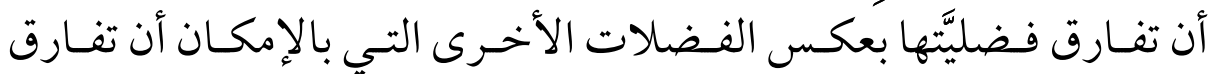

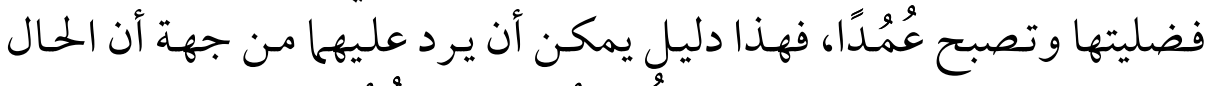

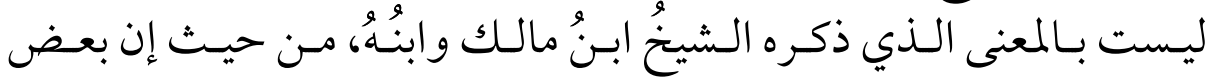

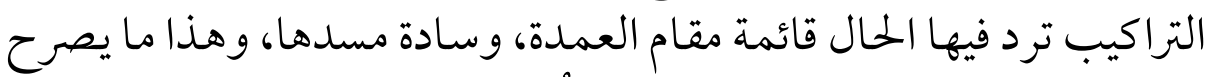

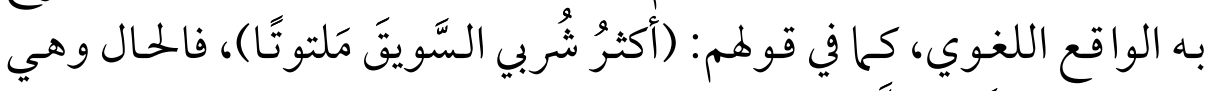

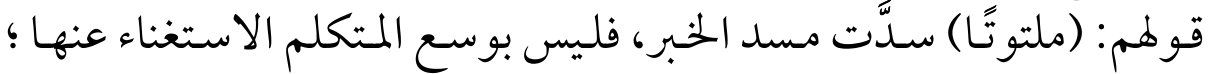
لأن التركيب يبقى محتاجًا إليها لتحام الفائدة (r).

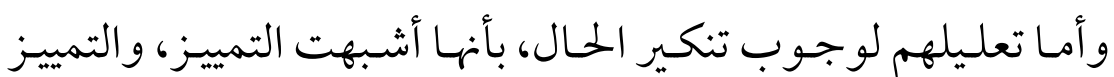

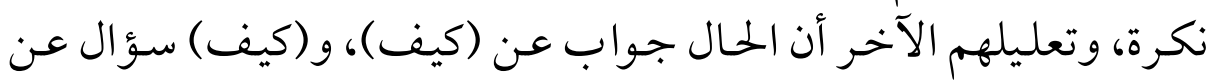

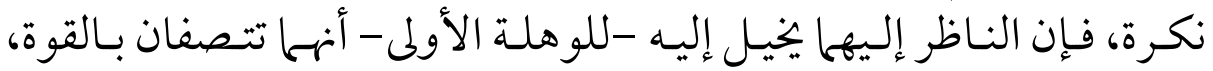

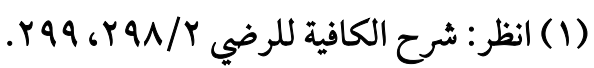

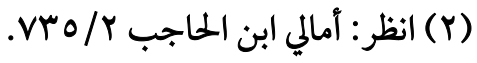

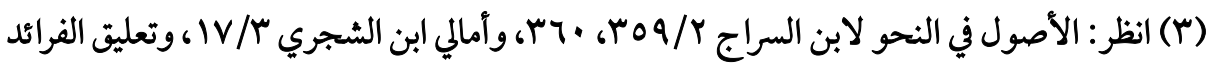

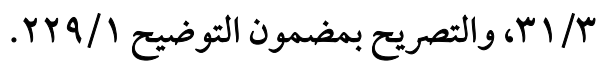




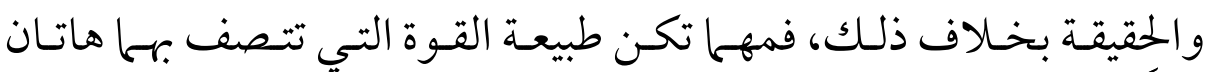
العلَّان فواقع المسألة يبقى محض افتراض فئس قائم على القياس النحوي.

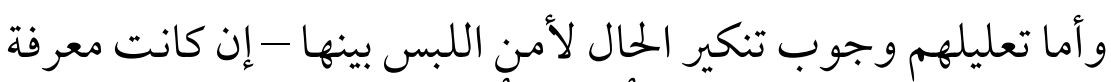

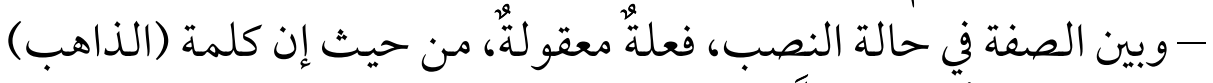

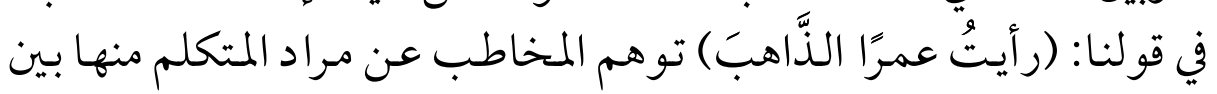
الوصفية والحالية. ومن هنا يظهر أن معظم ما افترضه النحويون مثثَّاً في تعليلاتهم لتقرير

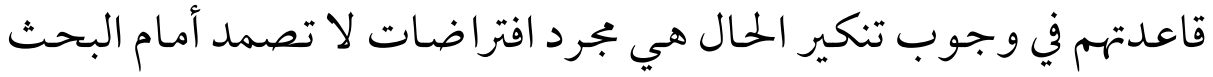
والمناقشة.

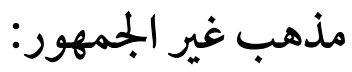

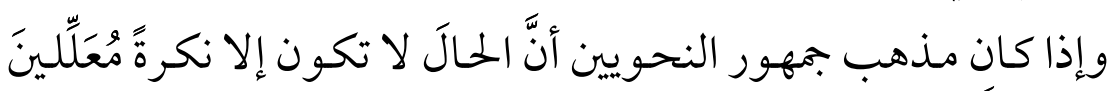

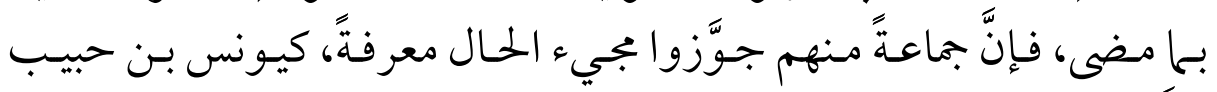

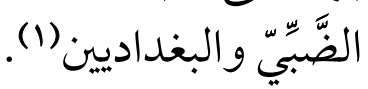
قال سيبويه: (او أمـا يـونس فيقـول: (مـررتُ بـهـ المسكينَ) على قوله:

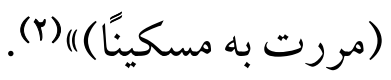

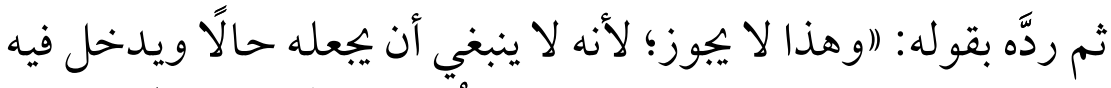

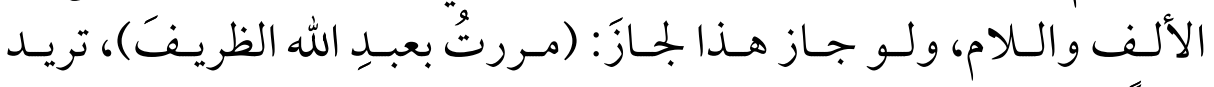

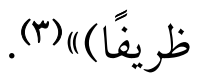

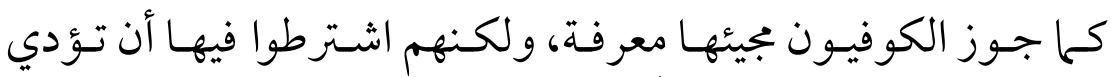

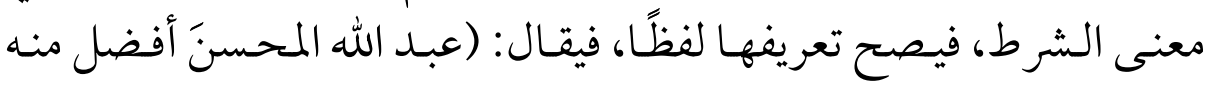

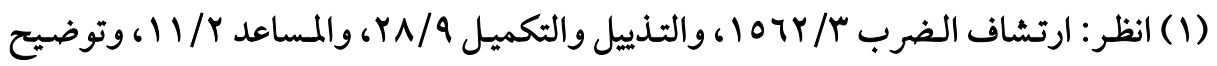

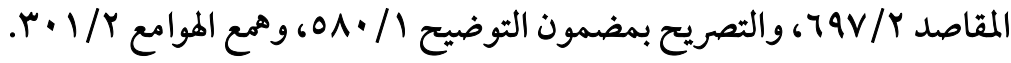

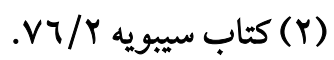

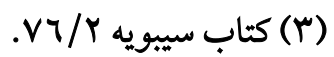




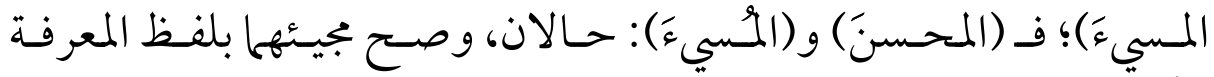

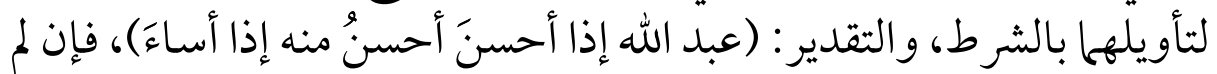

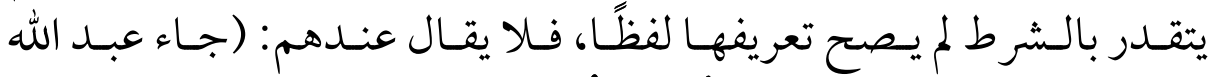

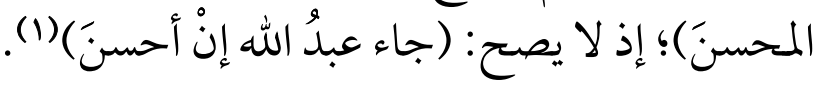
ورود الحال معرفة وتصرّف النحويين معه:

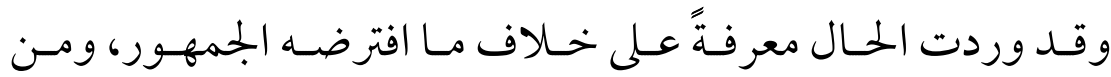
الشواهد على ذلك قول لبيد بن ربيعة العامري:

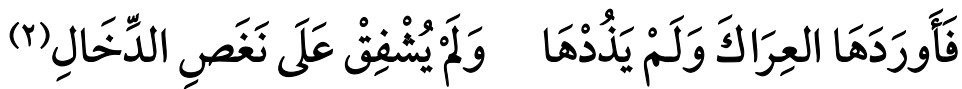

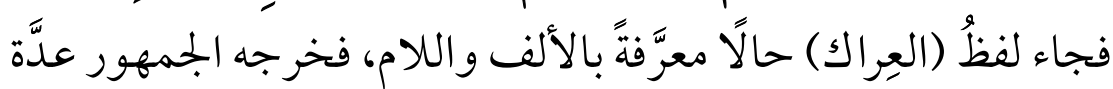

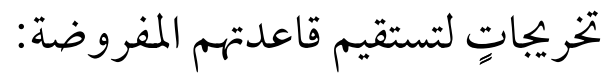

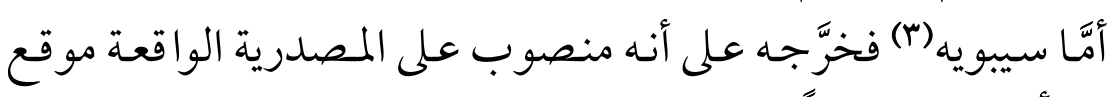
الحال، فكأنه قال: (اعتراكًا).

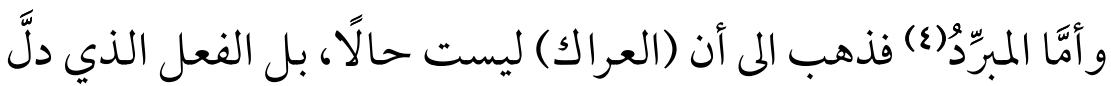

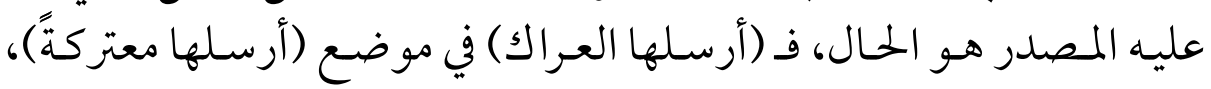

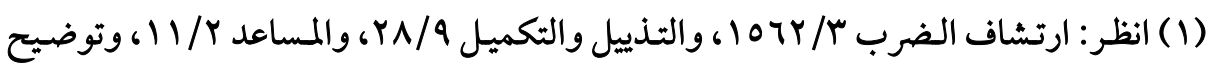

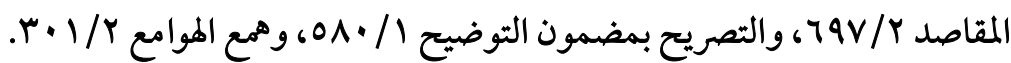

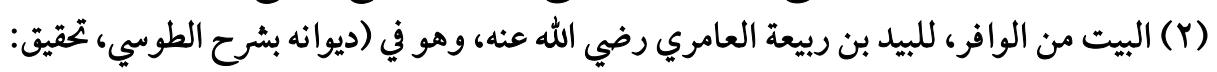

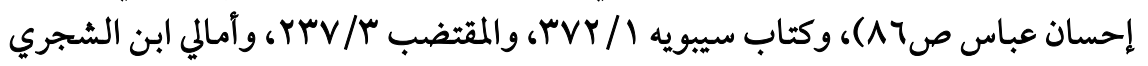

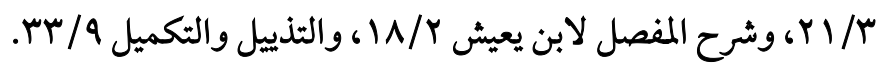

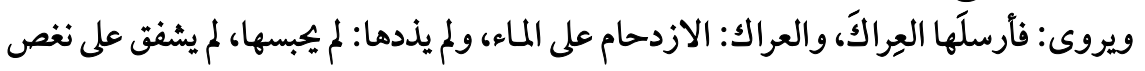

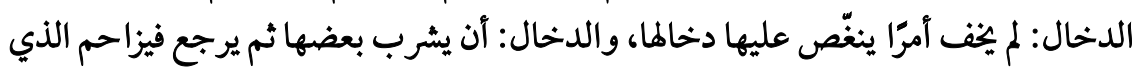
على الماء. والشاهد فيه قوله: (العراك) حيث وقعت الحال معرفة على مذهب يونس والبغداديين، وقد أوَّها

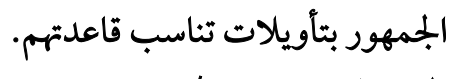

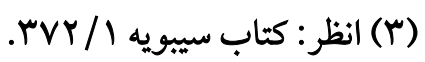

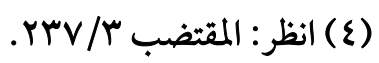




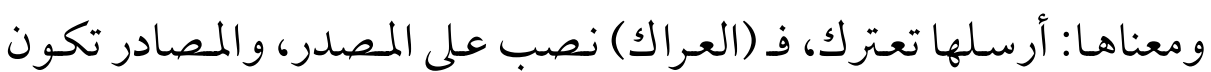

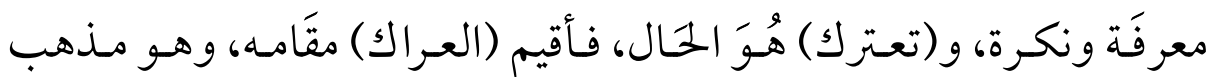

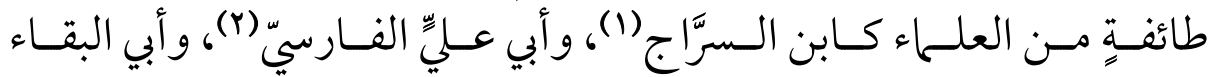

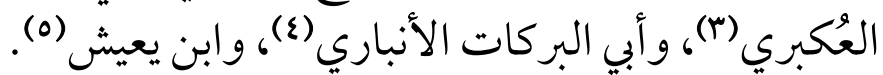

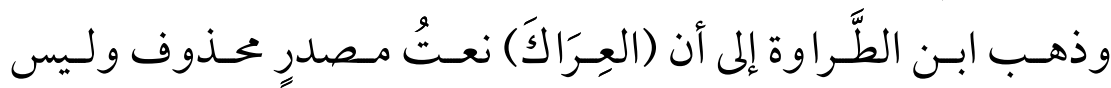

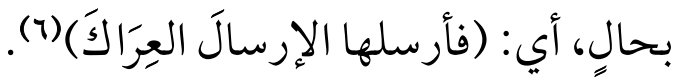

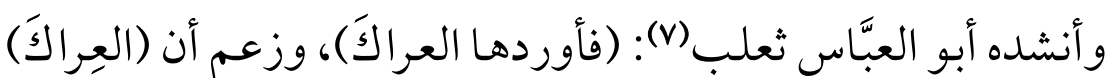

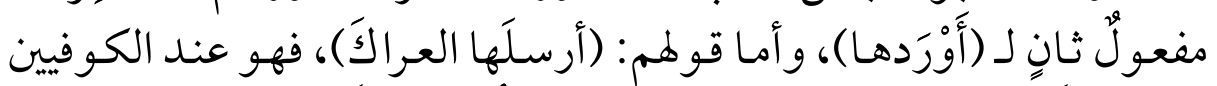

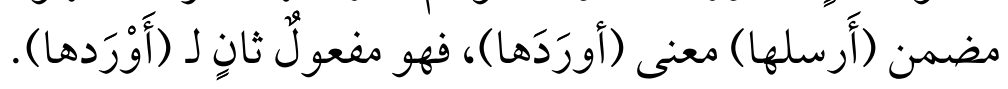

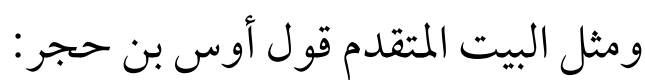

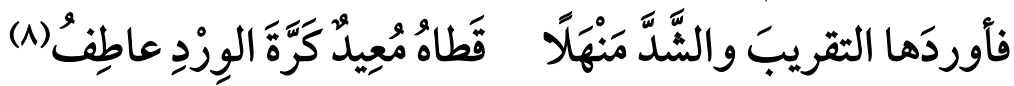

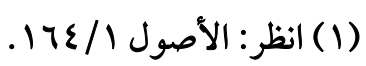

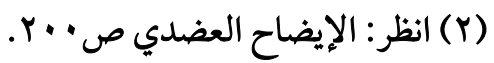

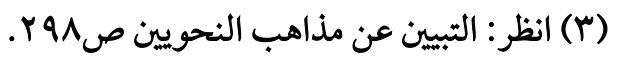

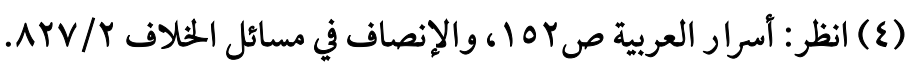

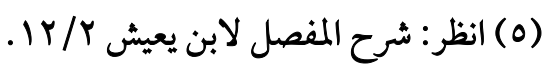

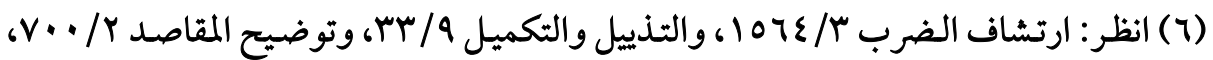

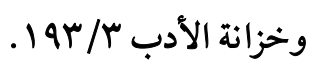

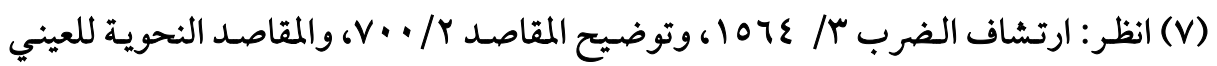

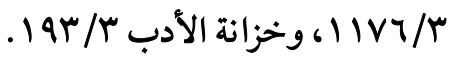

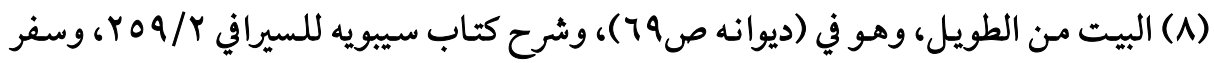

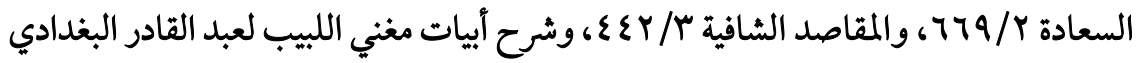
$.171 / 1$ يقولُ: فأورد أتانه منهلًا لا يخلو من الماء يعود قطاه إليه، والقطا تشرب، ولا تجوز بالشربة الأولى

$$
\text { لبعد المكان حتى تعود فتشرب مرة ثأنانية. }
$$$$
\text { والشاهد كسابقه. }
$$ 
فقوله: (أوردَها التقريبَ)، مثل قول لبيد (أورَدَها العِراكَ).

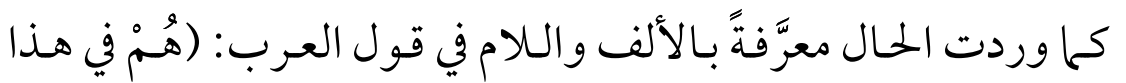

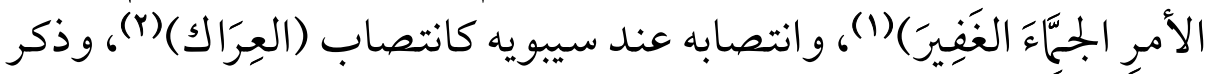

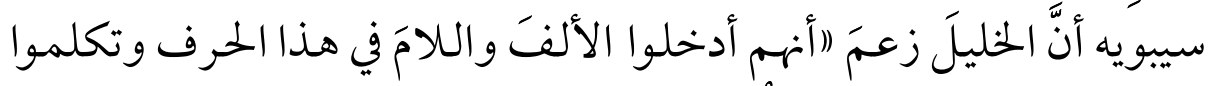

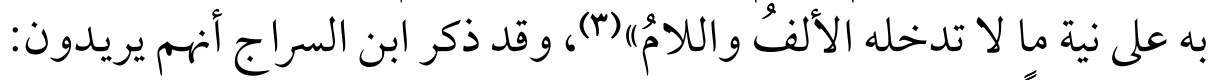

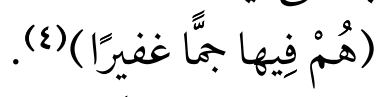

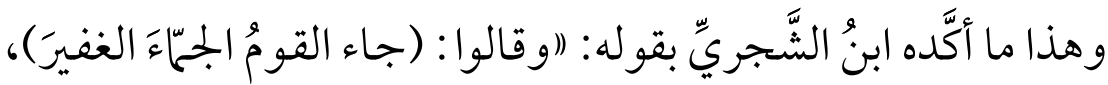

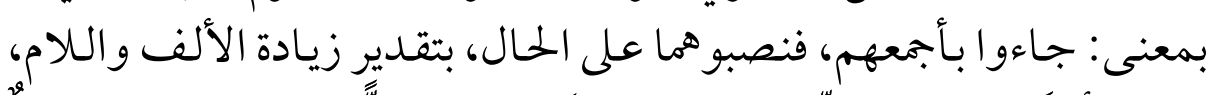

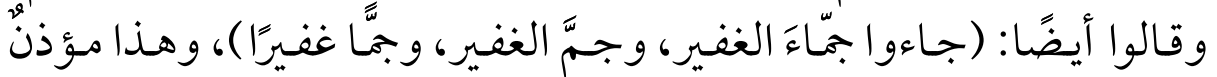

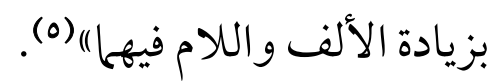

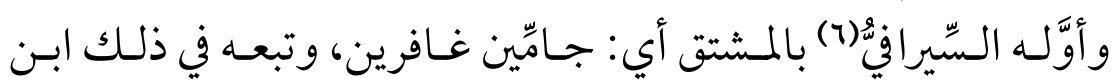

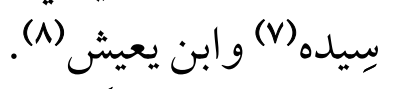

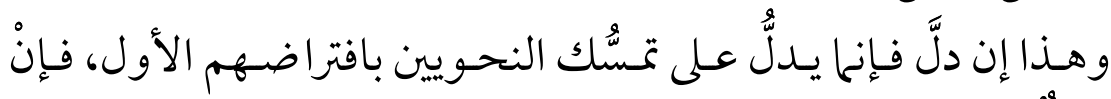

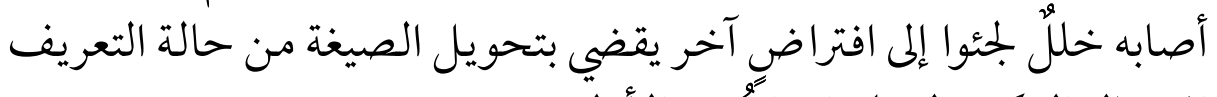

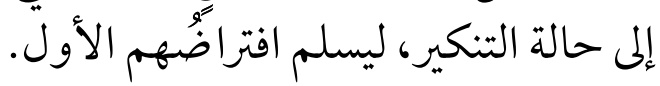

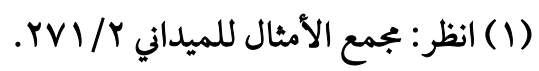

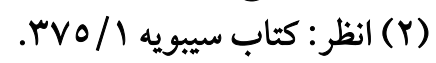

$$
\begin{aligned}
& \text { (Y) }
\end{aligned}
$$

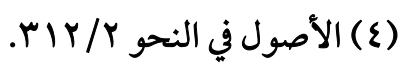

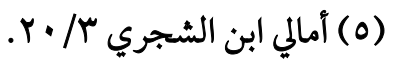

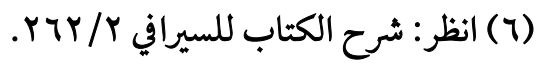

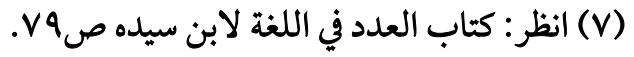

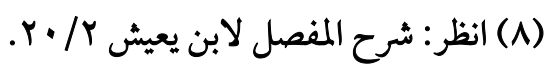


أمَّا الأخفـش والمـبرد فـذهبا إلى أنهـا ليـست بـأحوال في الحمقيقة، إنها

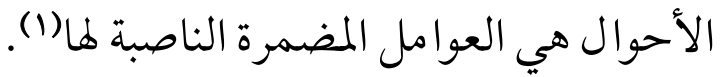

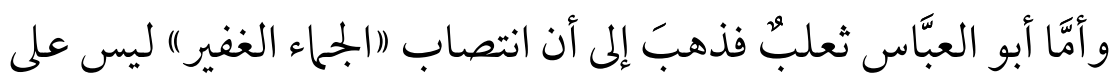

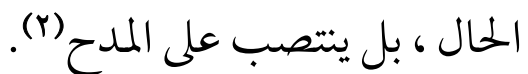

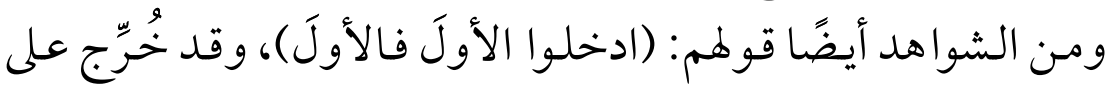

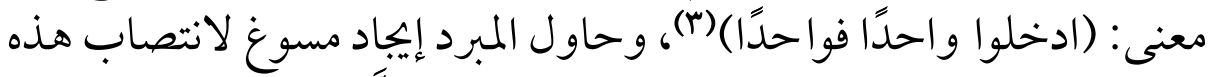

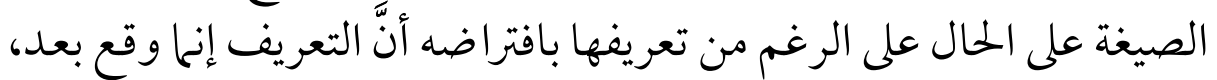

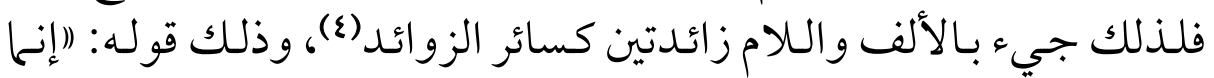

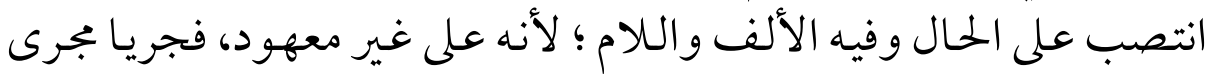
سائر الزوائد)(ه).

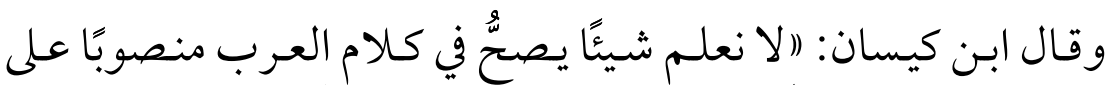

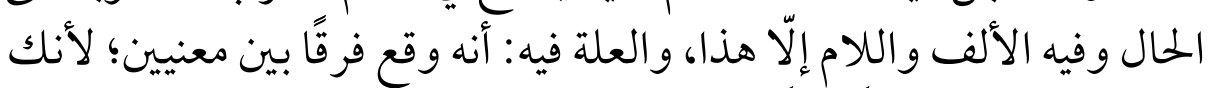

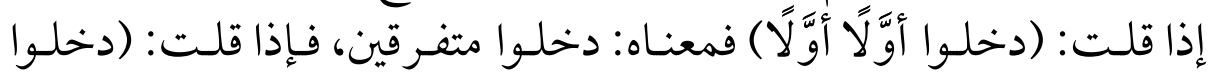

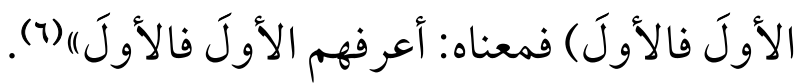

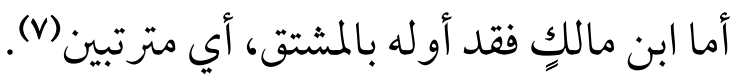

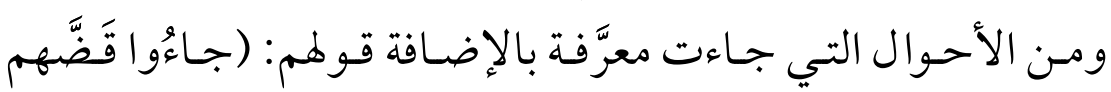
بقضيضِهم) (1)، ومنه قول الشماخ:

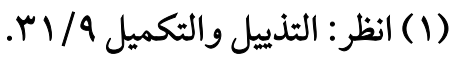

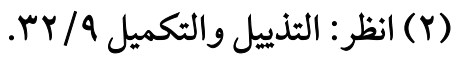

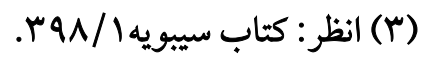

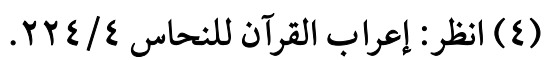

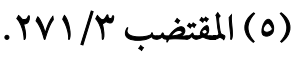

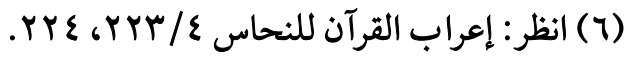

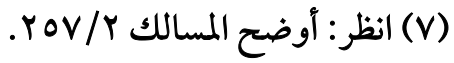

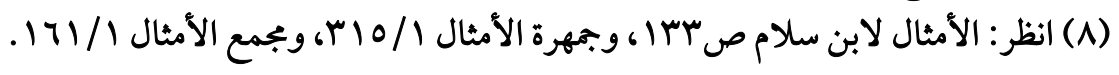




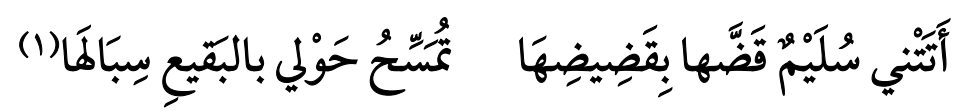

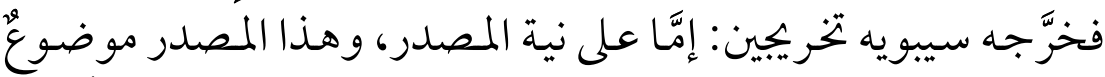

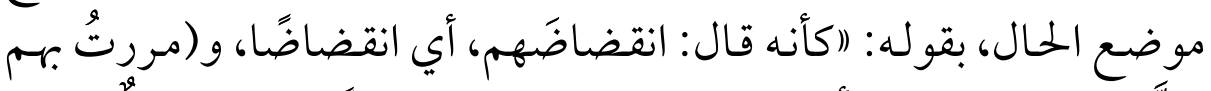

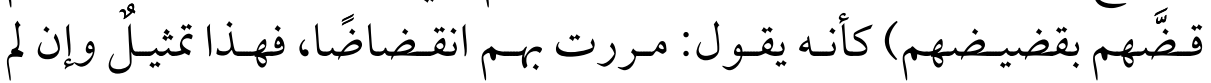

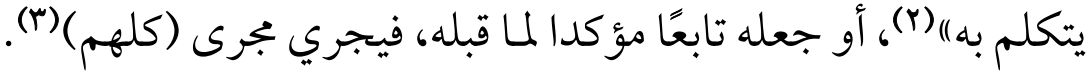

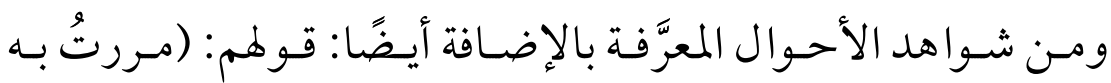

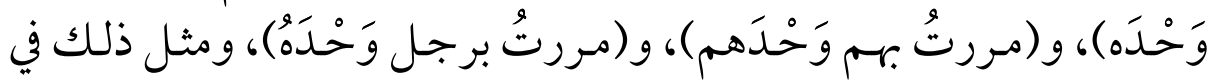

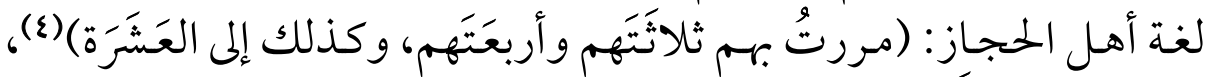

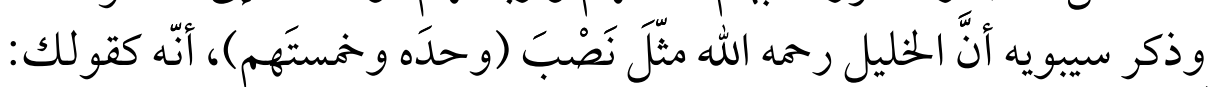

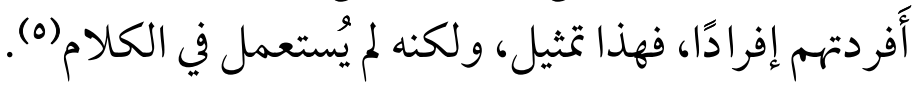

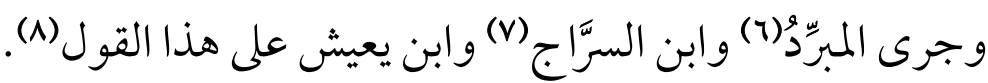

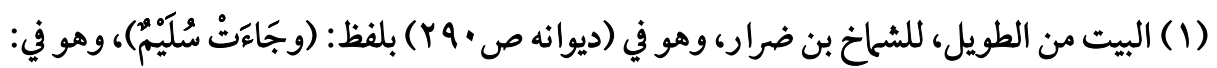

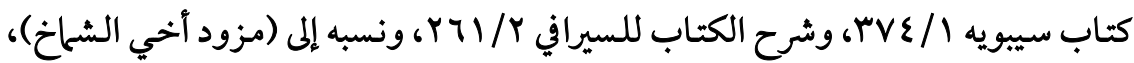

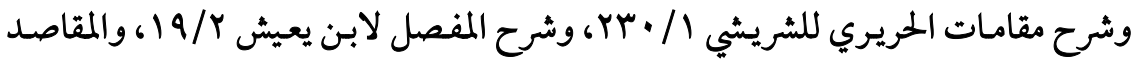

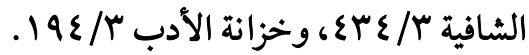

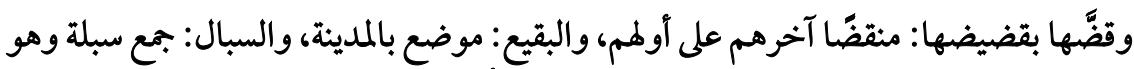

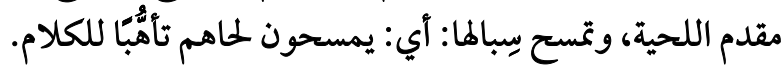

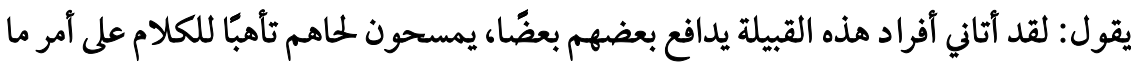
والشاهد فيه قوله: نصب (قضَّها) على الحالية مع أنه معرفة، والذي سَوََّّ ذلك أنَّ معناه التنكير.

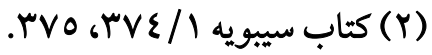

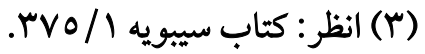

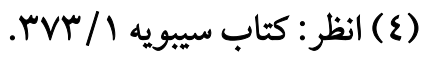

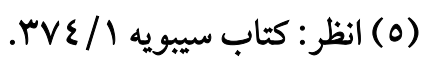

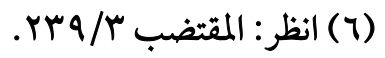

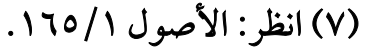

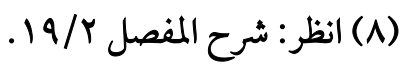




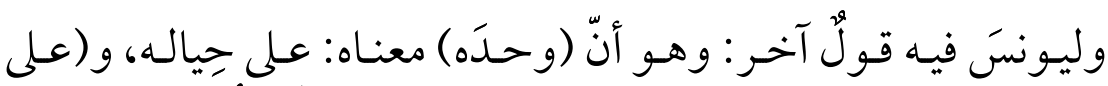

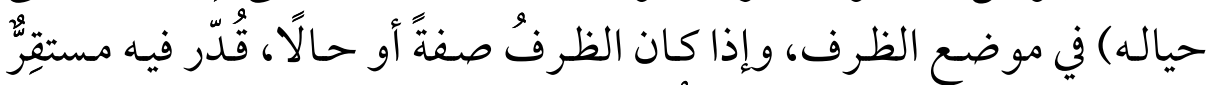

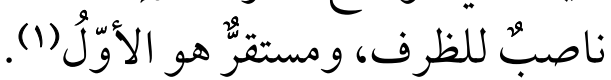

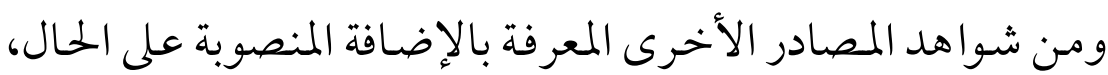

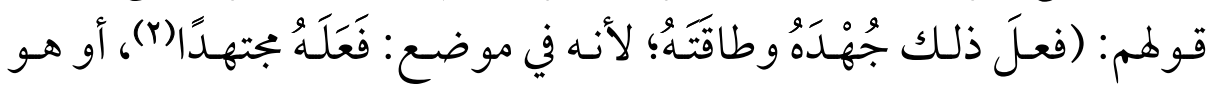

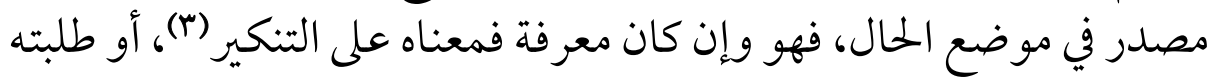

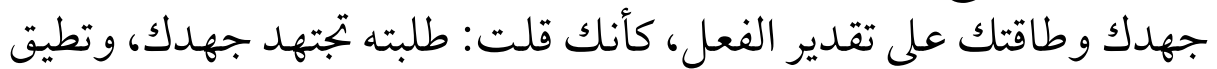
طاقتك (£)

إلى غير ذلك من شوا هد مبثوثة في كتب النحاة(0).

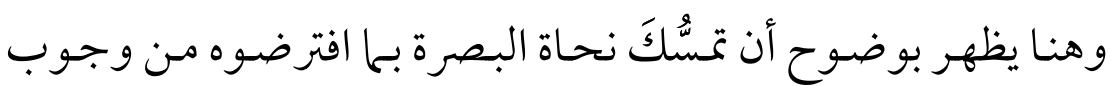

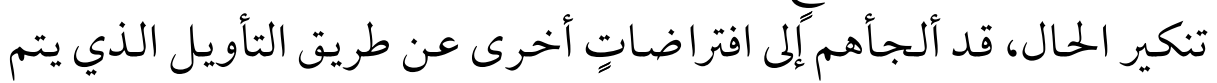

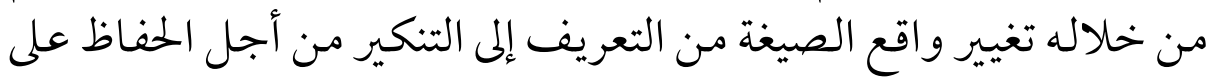

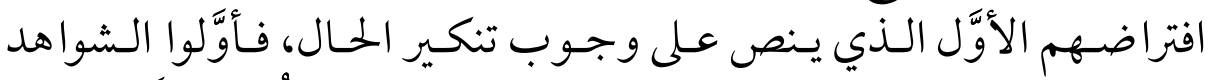

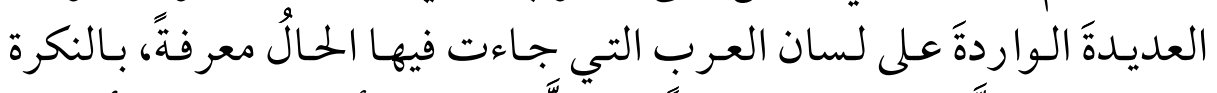

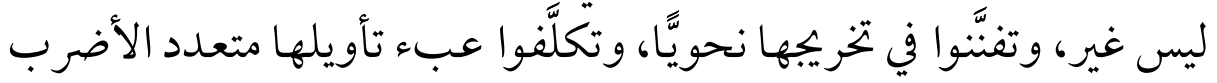

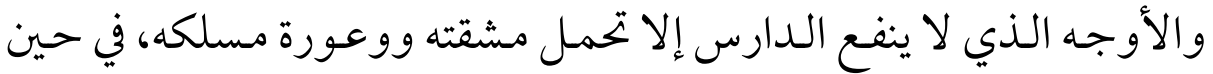

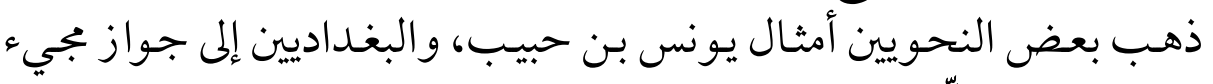

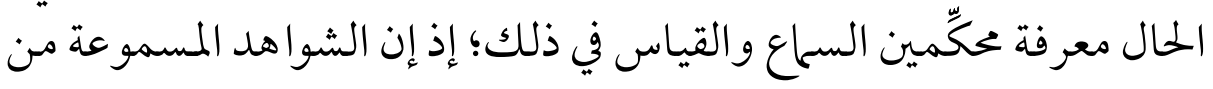

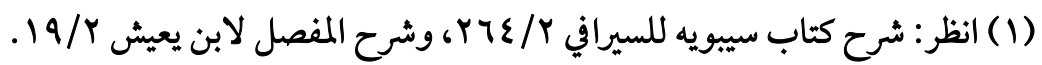

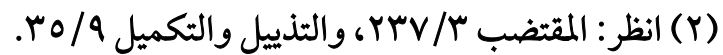

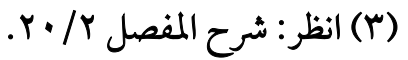

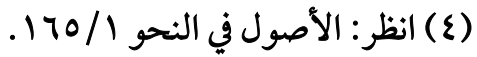

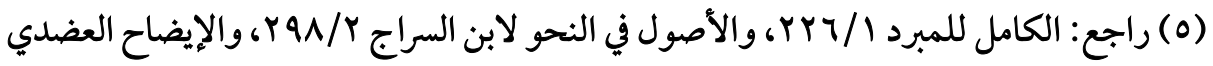

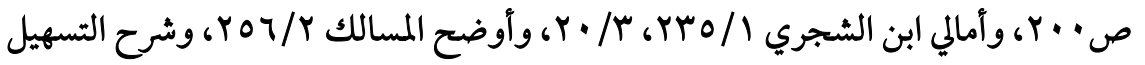

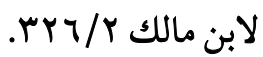


العرب تؤيد ذلك، وقياس الحال على الخبر الذي يجوز أن يرد نكرة كما يرد معرفة يعضد بجيء الحال معرفة.

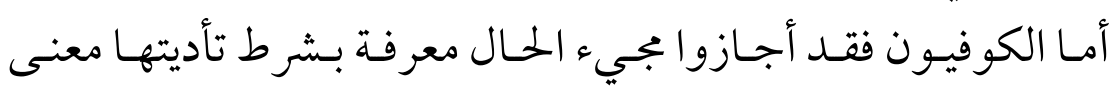

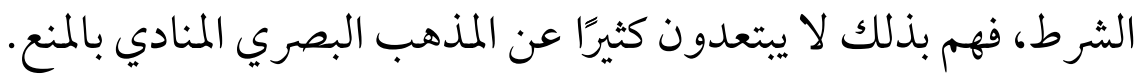

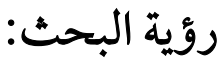

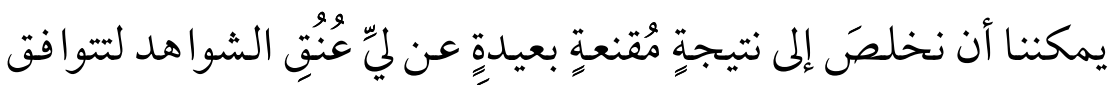

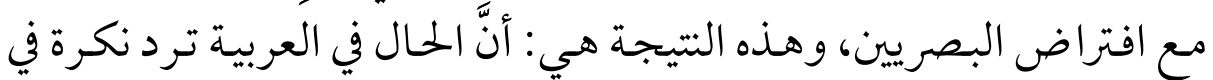

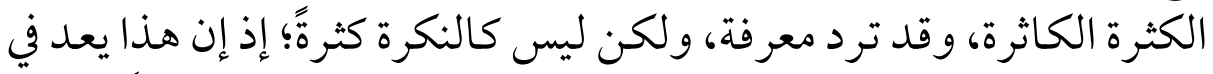

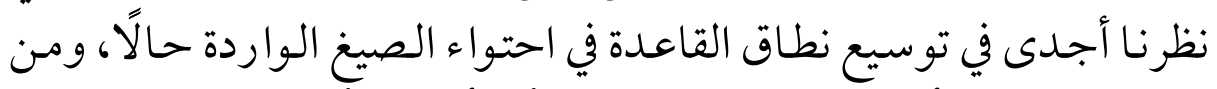

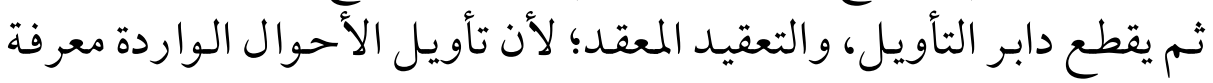
بالنكرة لا يخرجها عن القيمة الوضعية التي هي عليها.

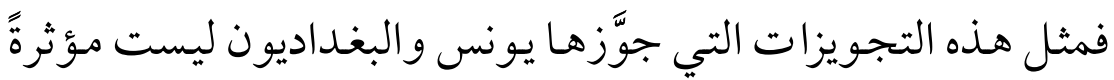

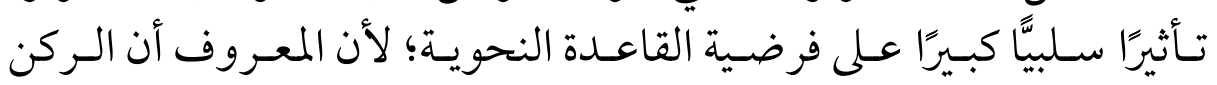

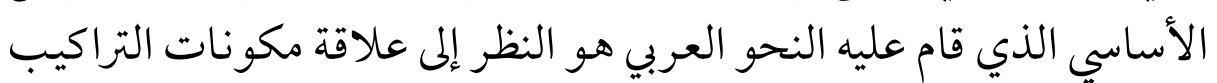

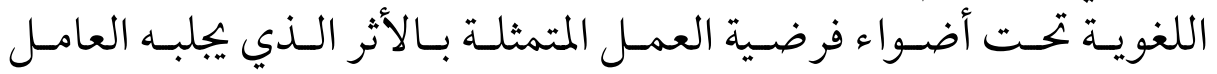

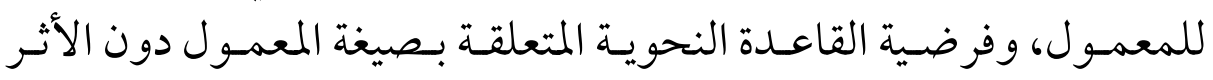

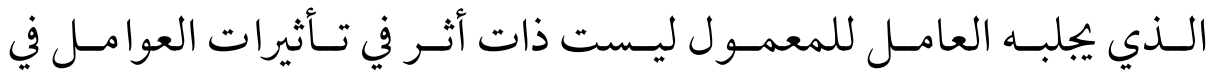

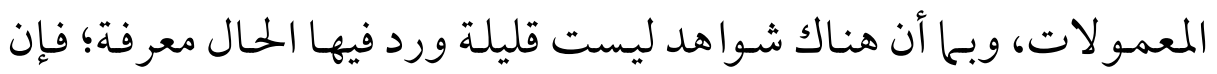

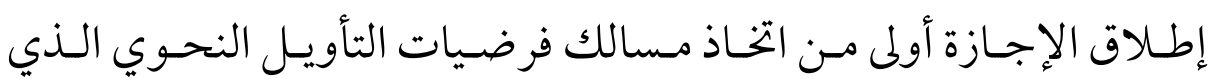

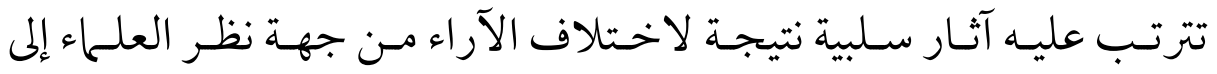

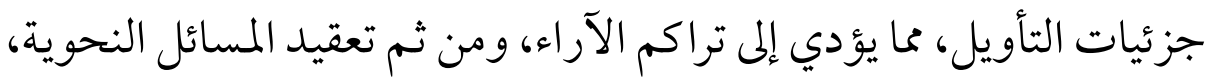

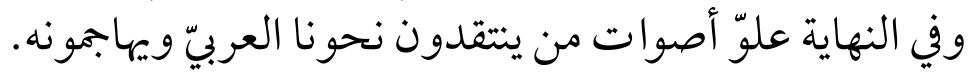




\section{التمبهيـزن:}

افترض البصريون أنَّ التمييز لا يكون إلان نكرةً، ولا يصحُّ بجيئهُ معرفةً

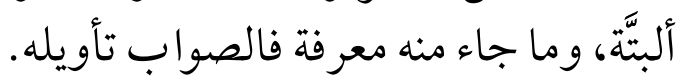

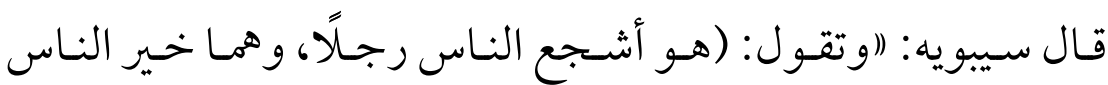

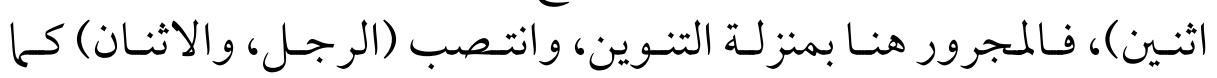

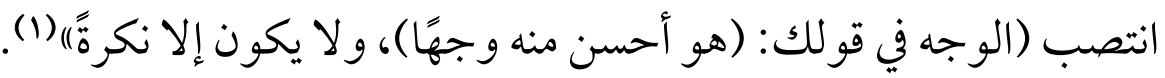

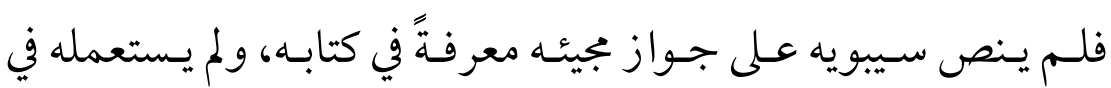
استشهاده إلا نكرة.

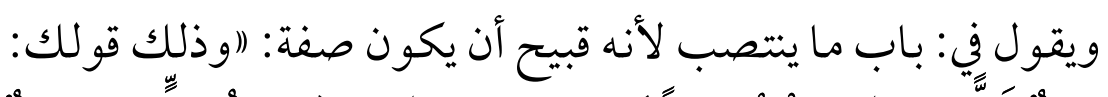

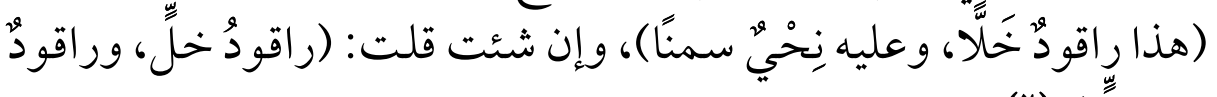

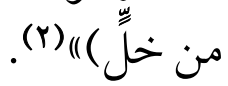

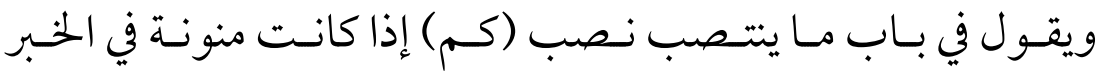

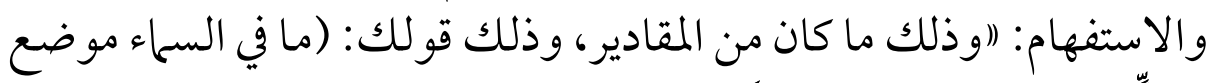

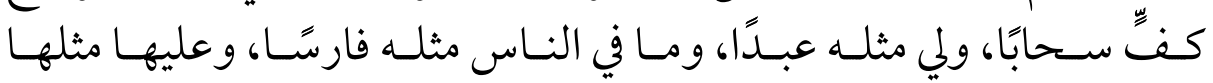
زبدًا) (r) (r) ويقول المبرد: (و لا يكـون في قولك: (كم غلم)نك) إلا الرفع، لأنه

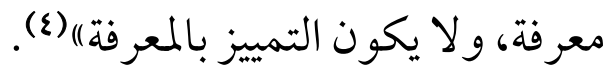

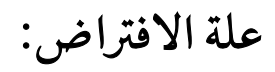
وقد علَّل البصريُّون لصحَّة افتراض كون التمييز نكرةً بالأمور الآتية:

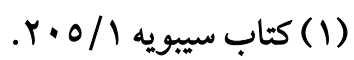

$$
\begin{aligned}
& \text { (Y) كتاب سيبويه } \\
& \text { IVY/Y كتاب سيبويه } \\
& \text { ( ) المقتضب ساب سيوريه }
\end{aligned}
$$




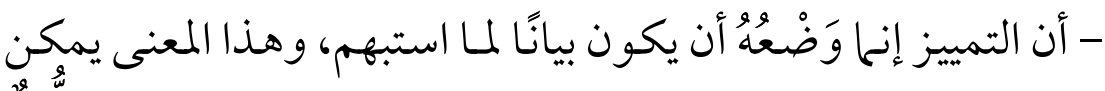

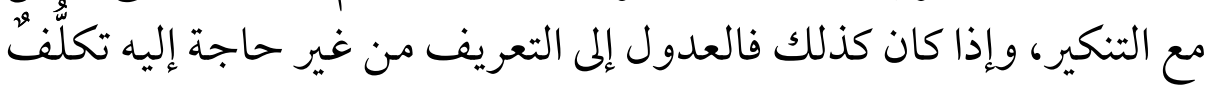

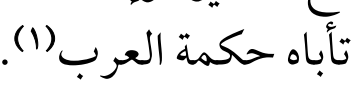

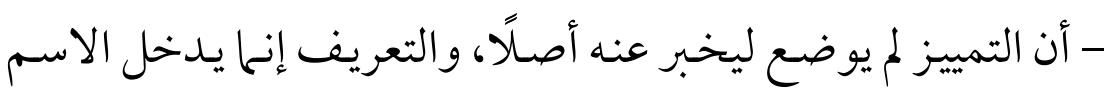

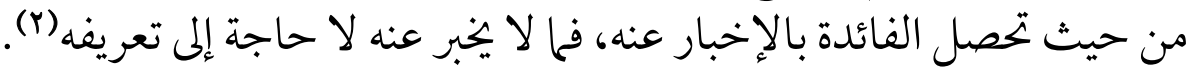

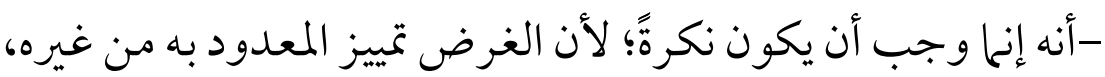

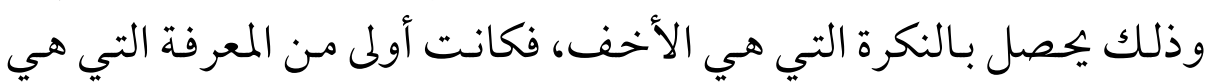
الأثقل (r) - (r) - أن التمييز مشبَّهُ بالخبر، وأصل الخبر أن يكون نكرةً، وأشبه التمبيز

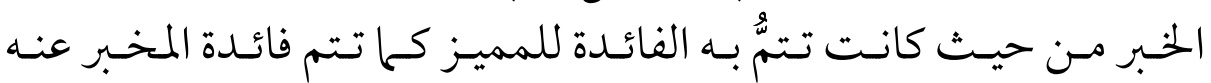

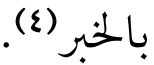

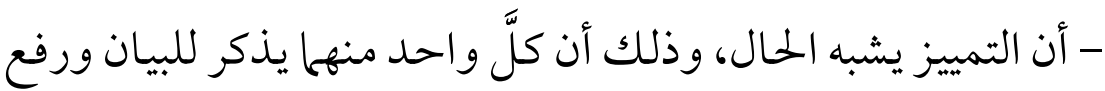

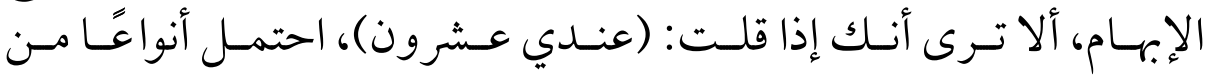

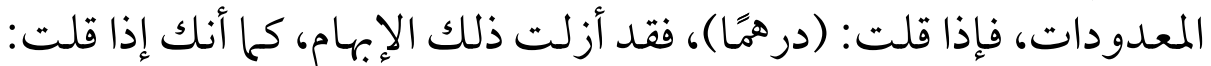

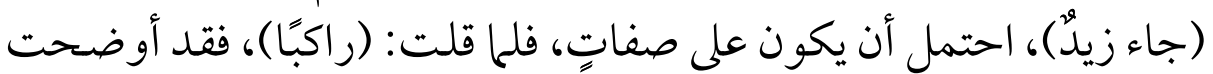

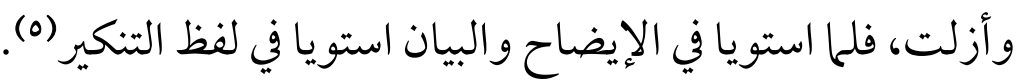

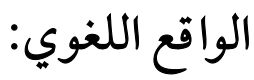

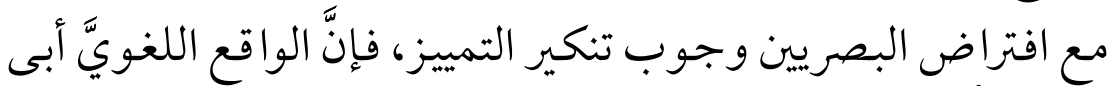

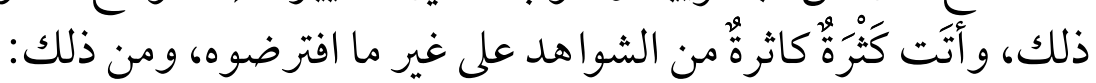
(1) (1) انظر: المقاصد الشافية/ (1)

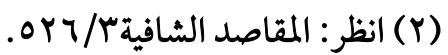

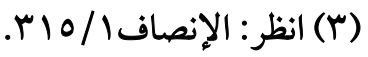

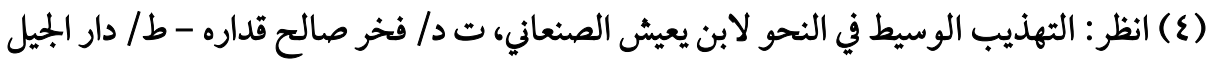

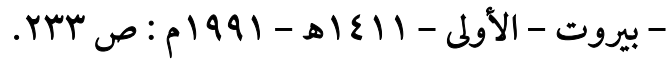

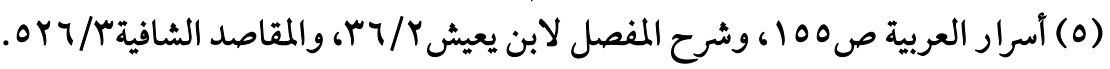




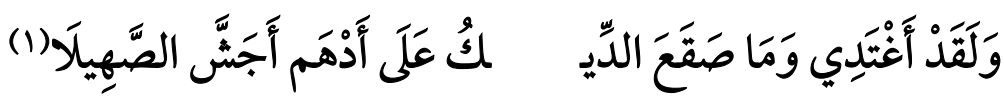

\section{قول الشاعر:}

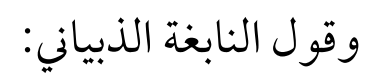

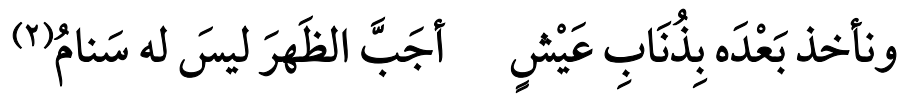

$$
\begin{aligned}
& \text { بنصب (الصهيل)، و(الظهر) على التمييز مع كونها معرفة. } \\
& \text { وقول أمية بن أبي الصلت: }
\end{aligned}
$$

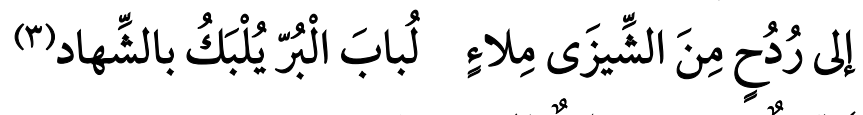

$$
\begin{aligned}
& \text { ف (لباب) تمييز، وهو مضافَّ وإلى معرفة. }
\end{aligned}
$$

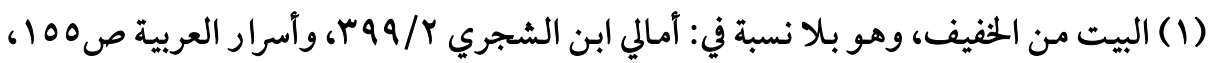

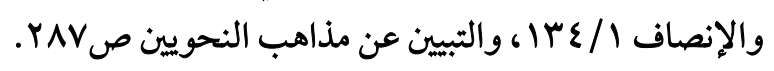

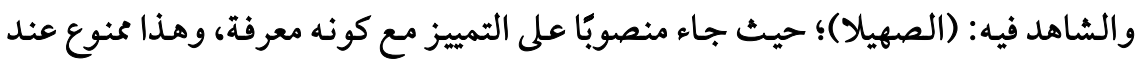

$$
\text { البصريين، جائز على رأي الكوفيين. }
$$

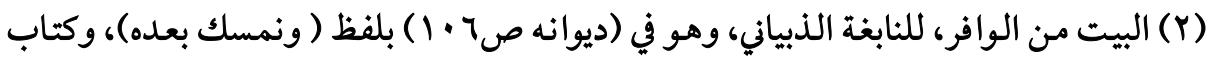

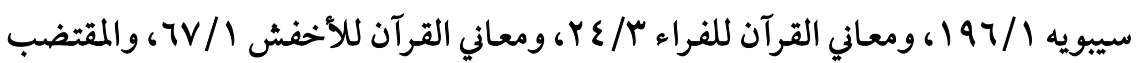

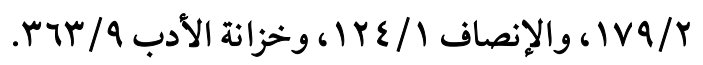

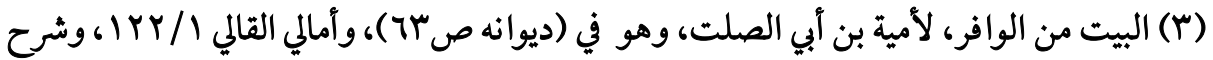

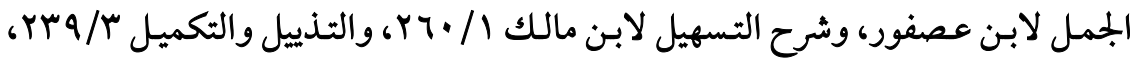

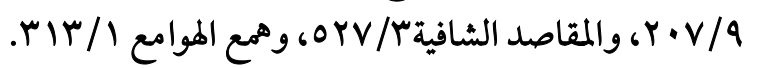

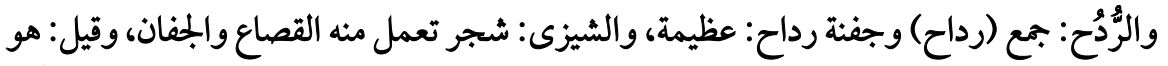

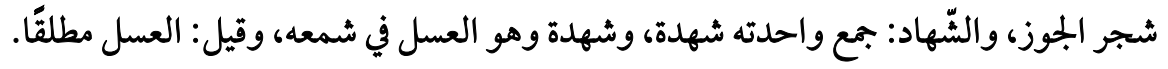

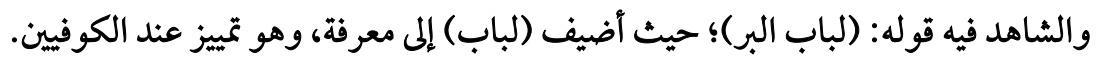




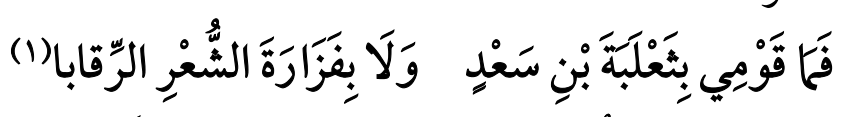

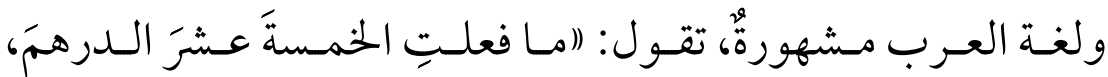

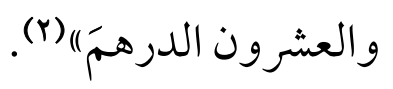

وقول ابن شهاب اليشكري:

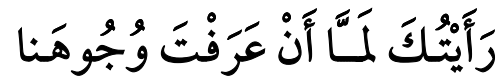

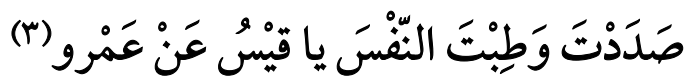

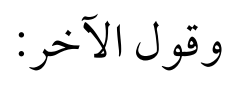

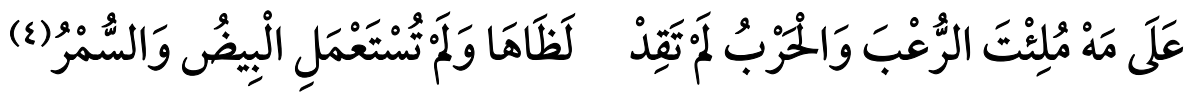

(1) البيت من الوافر، للحارث بن ظالم في: المقتضب ع / الا 1 ا، وشرح أبيات سيبويه لابن السيرافي

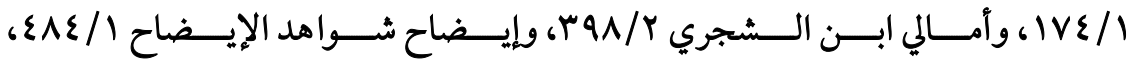

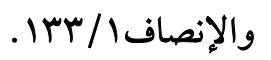

والشاعر يتنصّل من أن يكون قومه من نسب سعد بن ذبيان، فهم ليسوا من بني ثعلبة بن سعد، ولا

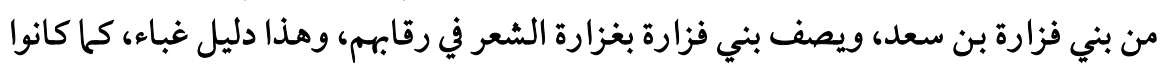

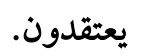

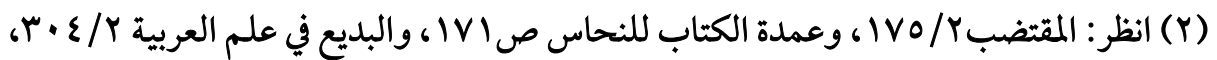

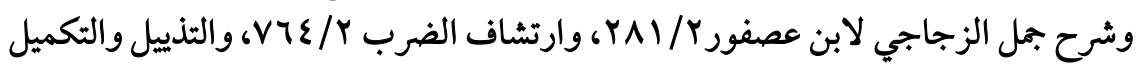
ال

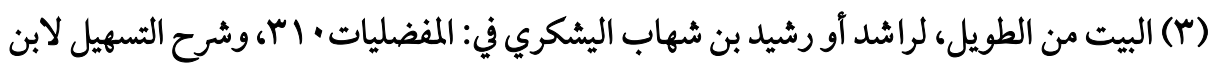

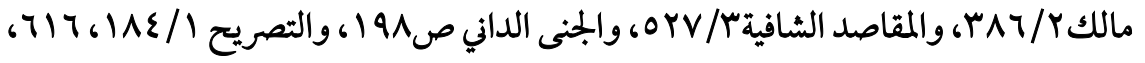

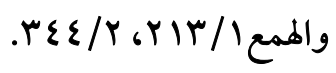

والشاهد: (وطبت النفس)؛ حيث جاء (النفس) تمييزًا وهو معرفة، وهذا جائز عند الكوفيين وابن

$$
\text { الطراوة. }
$$

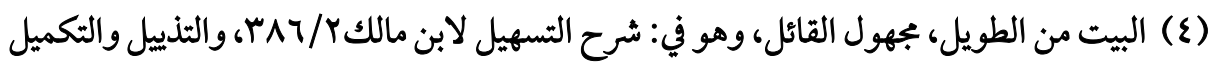

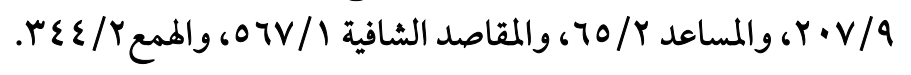




$$
\text { فو (النفس) و(الرعب) تمييزان وهما معرفتان. }
$$

$$
\text { وقول الشاعر: }
$$

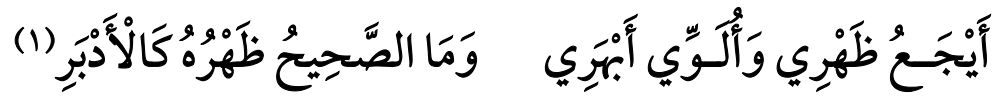

فـ (أيجحُ) فعـل لازم، و(ظهري) منصوبُ على التمييز، وهـو معرَّف

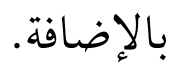

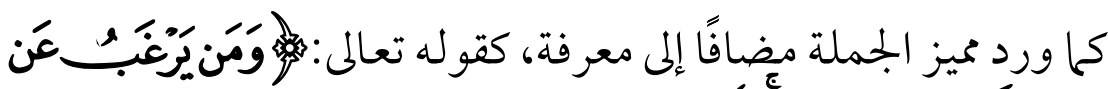

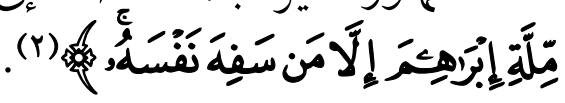

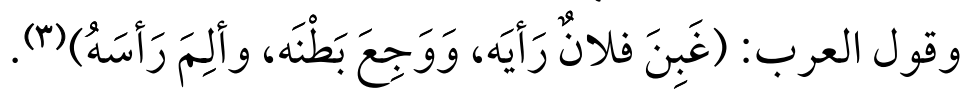

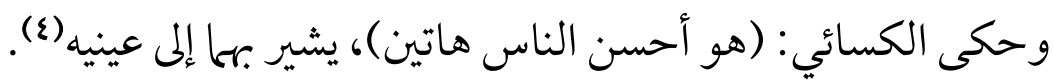

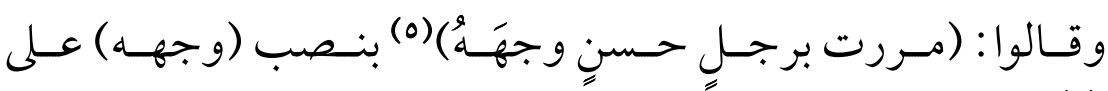

(1) البيت من الرجز، ولم أقف على قائله، وهو في شرح كتاب سيبويه للسيرافي / V9، ولسان العرب

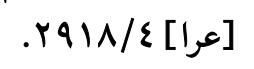

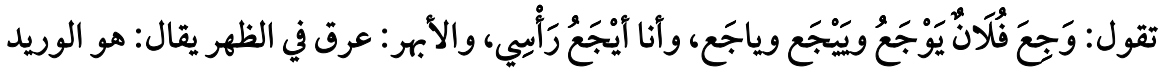

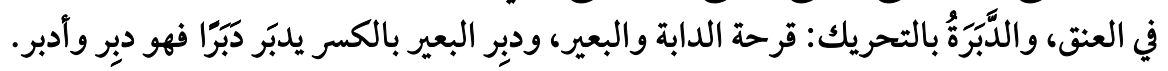
والشاهد في قوله: (أيجع ظهري)؛ فإن (أيجع) فعل لازم، و(ظهري) منصوب اليجري على التمييز، وهو

$$
\text { معرَّف بالإضافة. }
$$

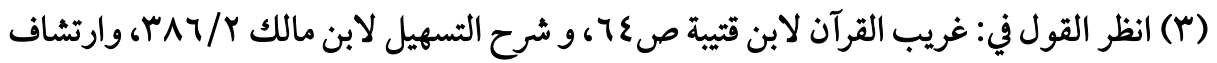

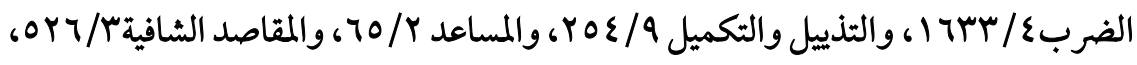

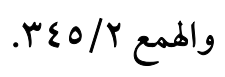

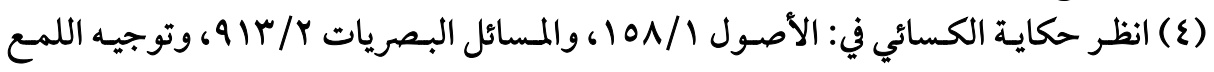

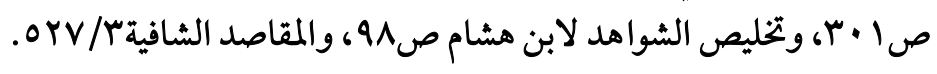

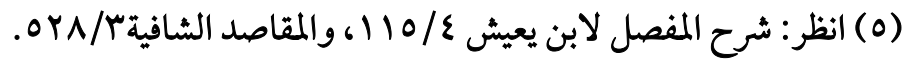

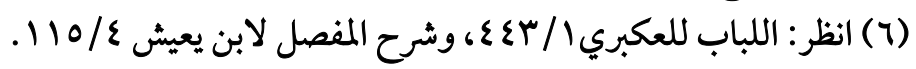




$$
\text { وفي الحديث(1): ( تهراق الدماءَ). }
$$

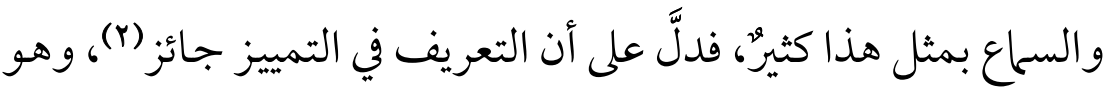

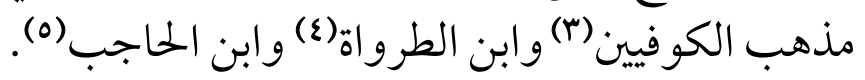

\section{صنيع البصريين مع هذه الشواهد:}

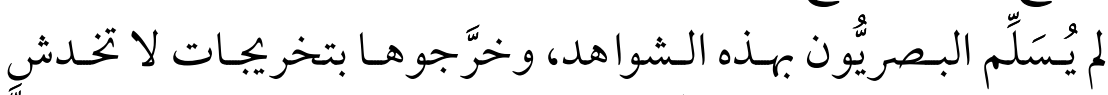

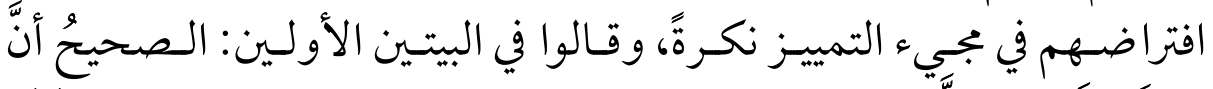

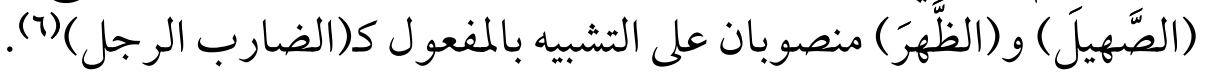

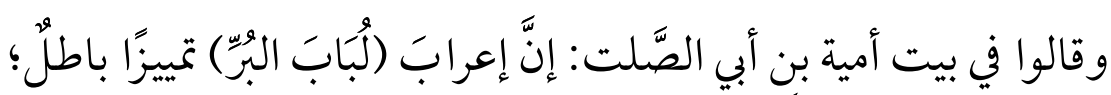

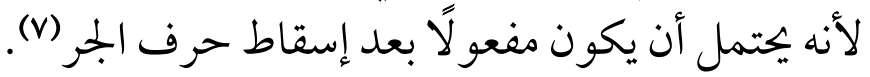

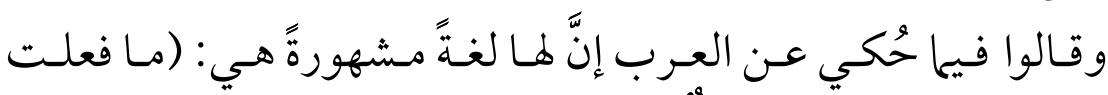

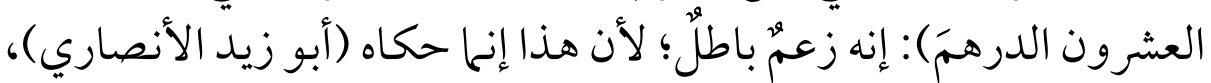

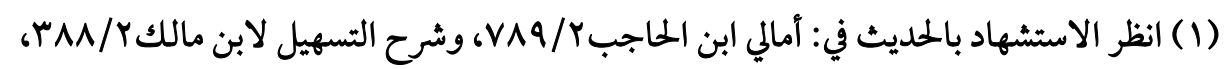

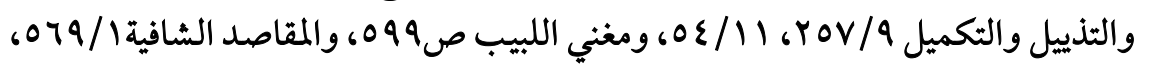
$.0 \mathrm{~V}$.

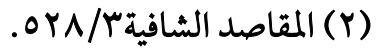

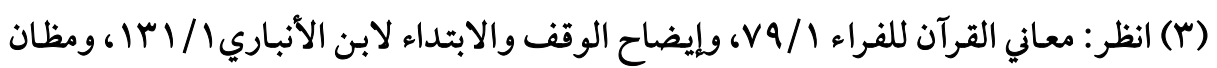

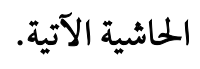

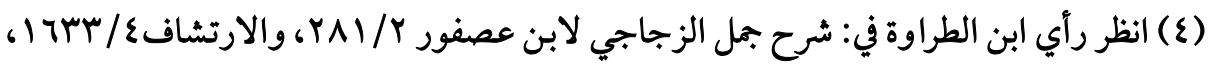

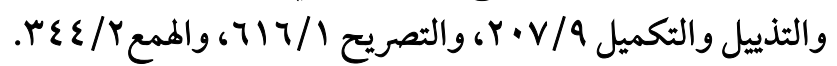

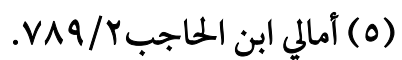

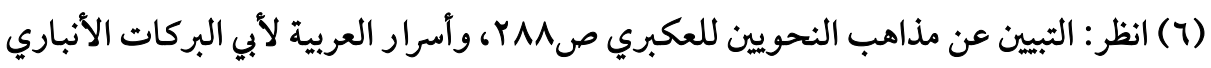

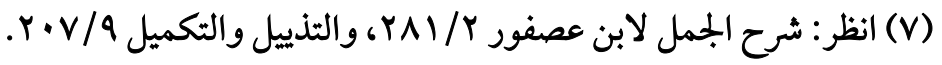


ولم يقل : إنها لغة العرب، ويمكن أن يقال: إن (الألف واللام) فيها زائدة،

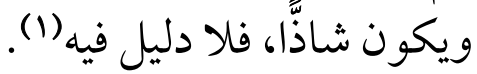

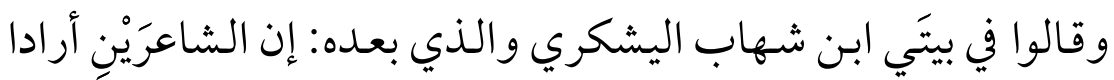

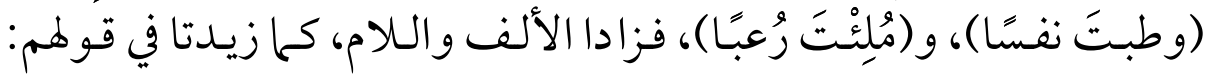

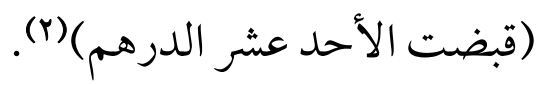

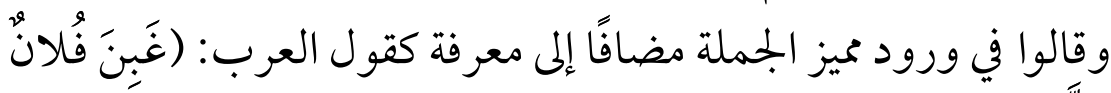
رَأَيْهَ): إنَّ فيه توجيهات في وردو

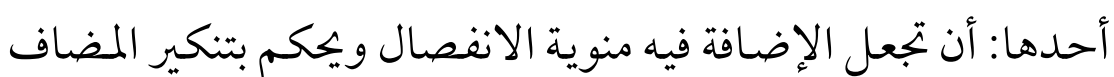

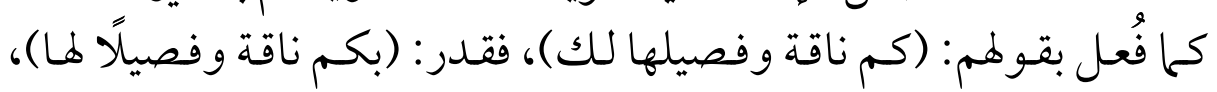

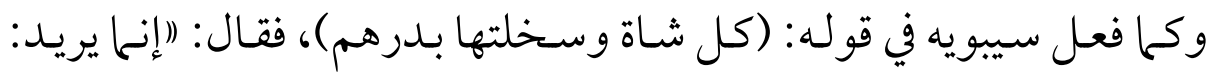

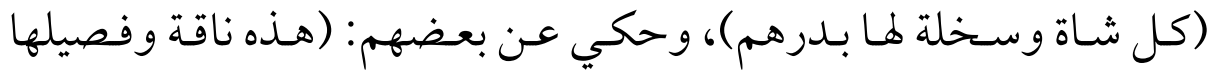

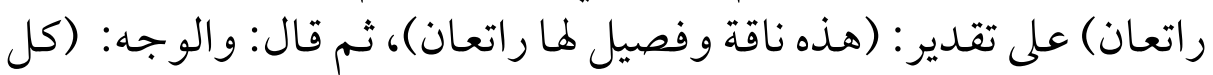

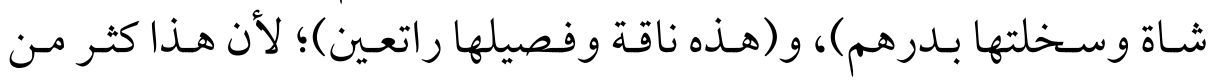

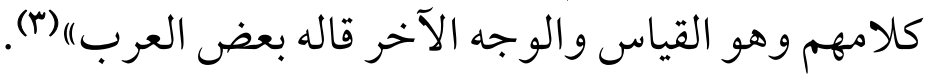

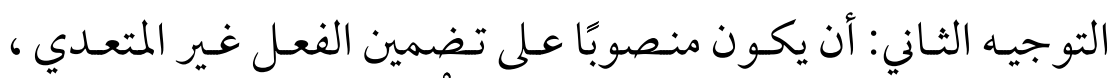

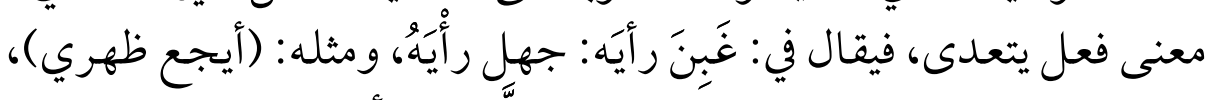

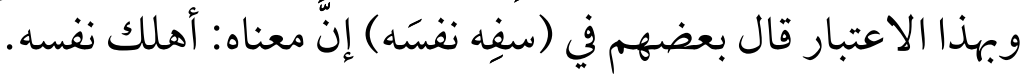

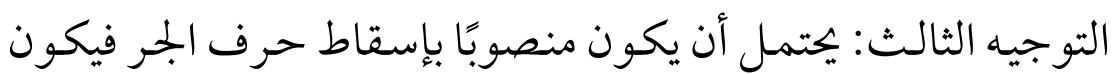
(غبن في رأيه).

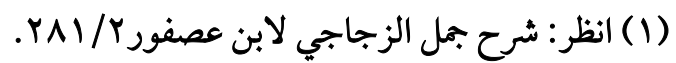

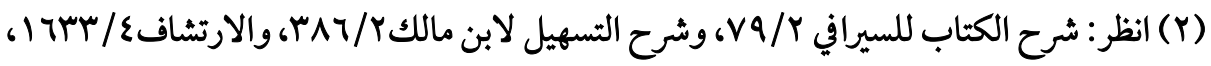

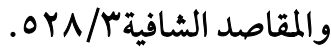

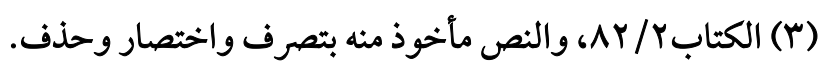
11199 
التوجيه الرابع: أن ينصب (رأيه) وما كان مثله على التشبيه بالمفعول

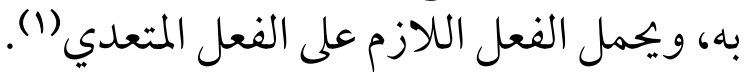

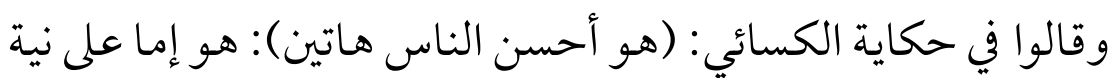

التنكير، كقول عبد الله بن الزَّبير الأسدي: (هو آحئين

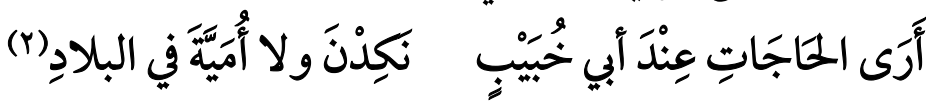

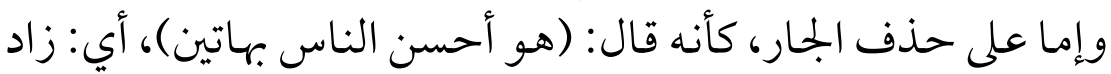

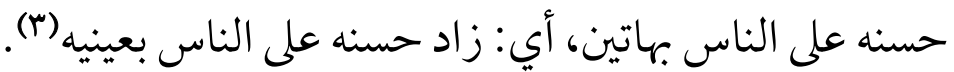

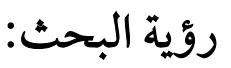

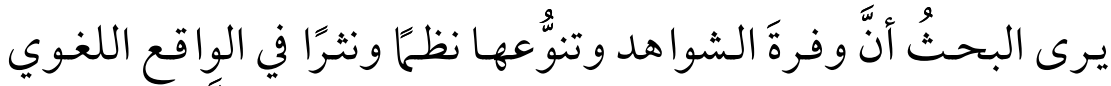

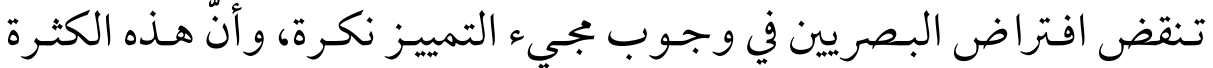

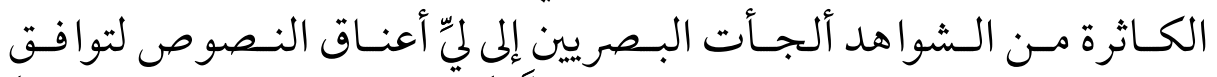

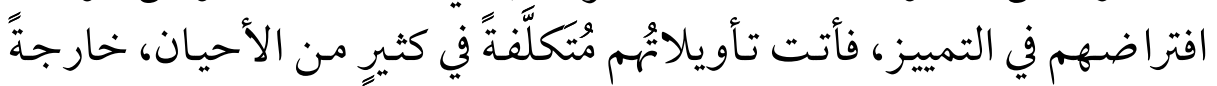
عن بعض أصول العربية.

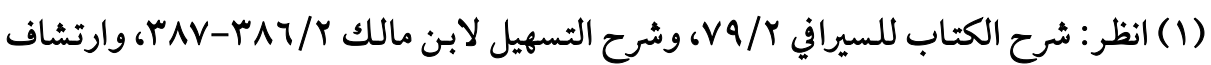

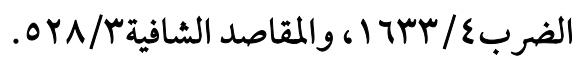

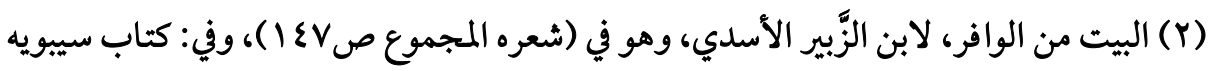

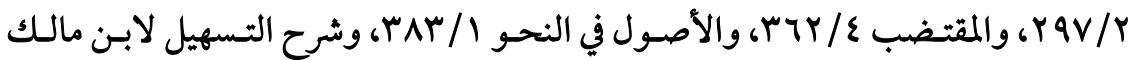

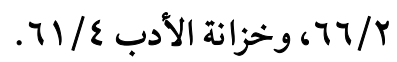

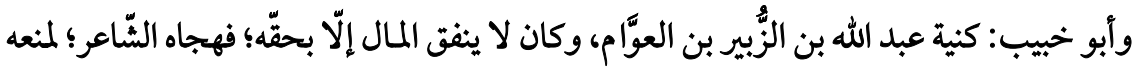

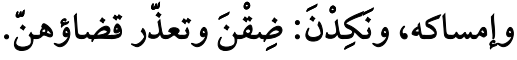

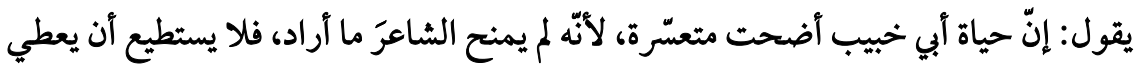

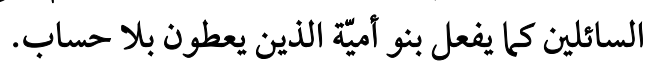

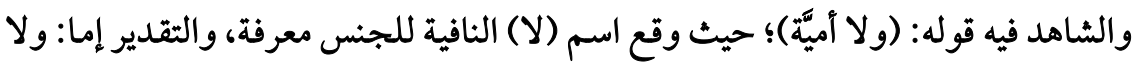

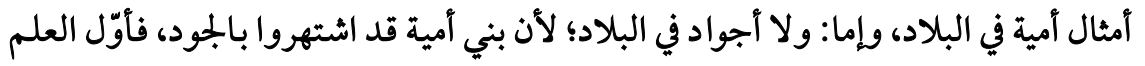

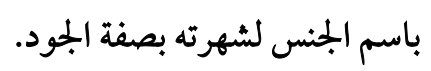

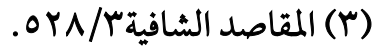




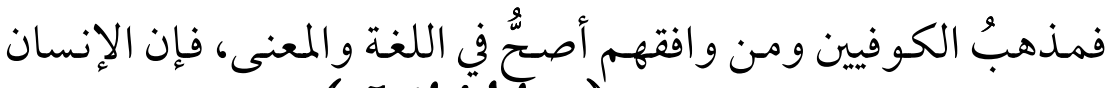

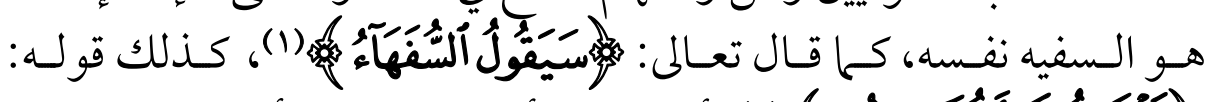

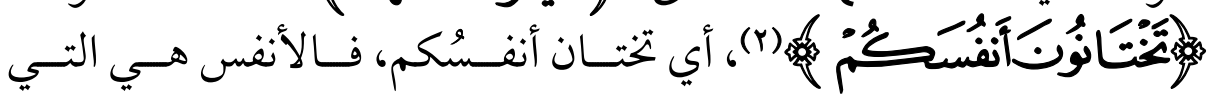

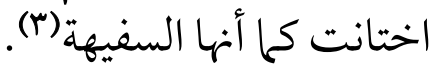

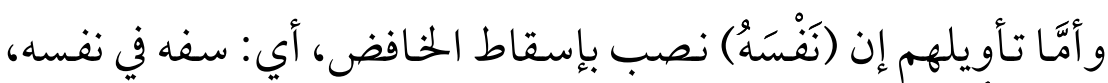

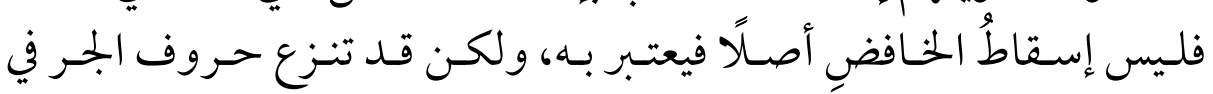

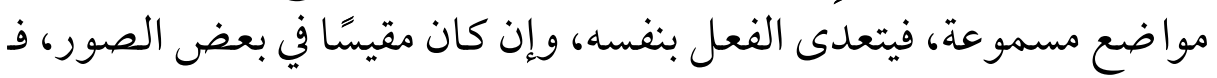

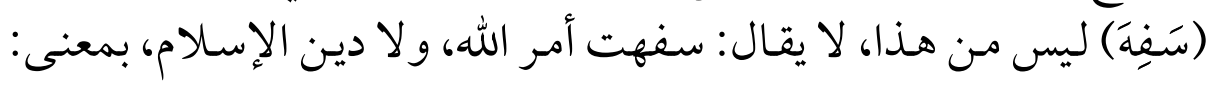

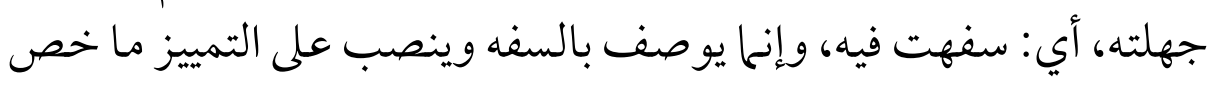

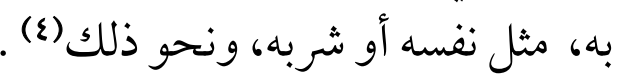

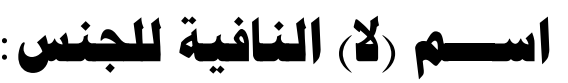

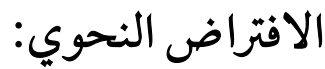

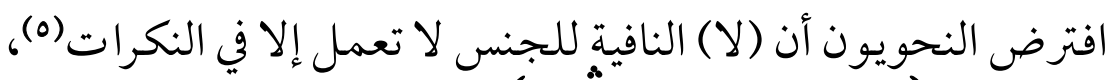

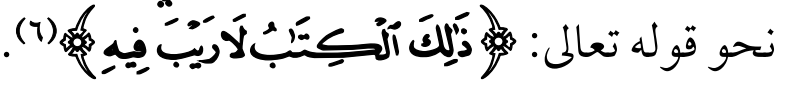

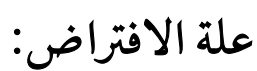

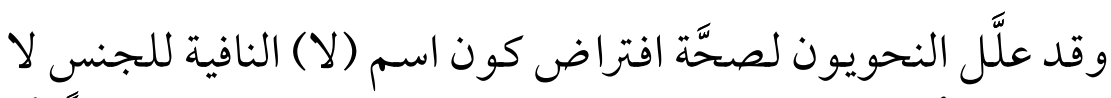

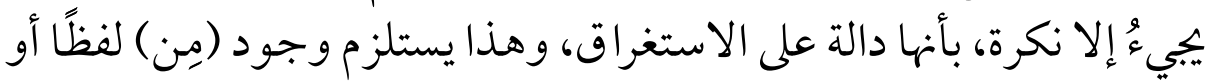

$$
\begin{aligned}
& \text { (1) سورة البقرة من الآية (Y) (I) ). }
\end{aligned}
$$

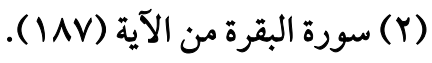

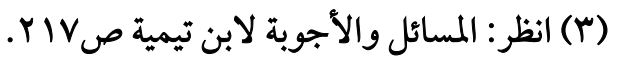

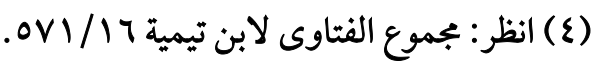

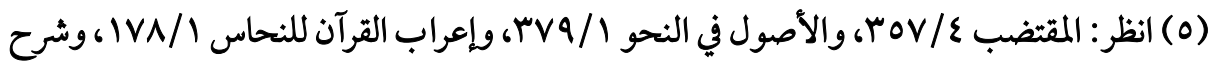

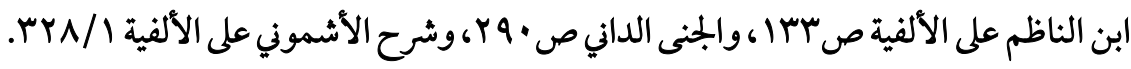

(7) (7ورة البقرة، من الآية الثانية. 
معنى، ولا تتحصل هذه الدلالة إلا بالاسم النكرة، وقد حملوها على نظائرها

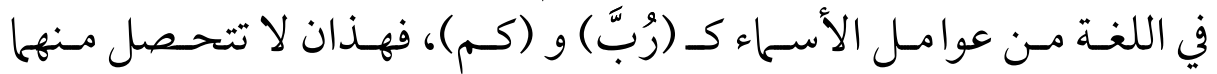

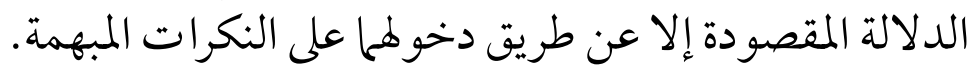

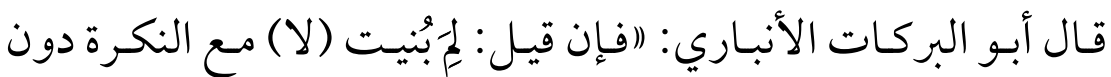

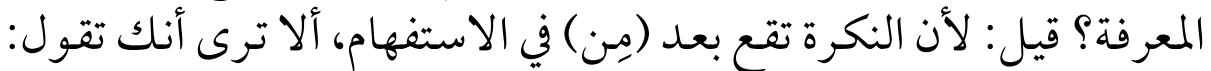

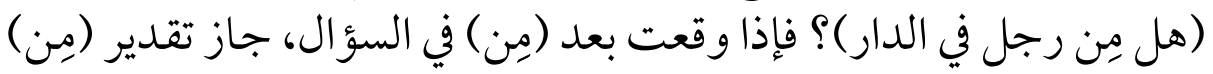

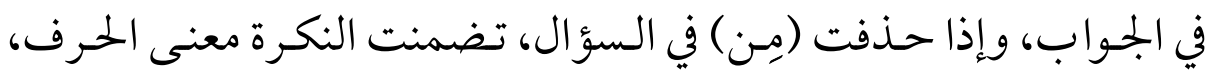

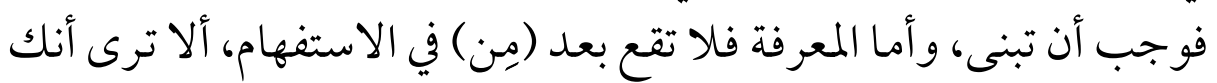

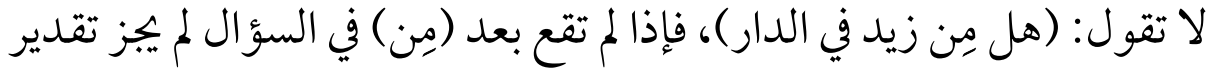

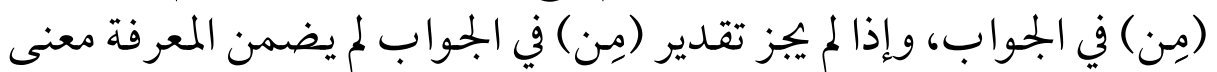

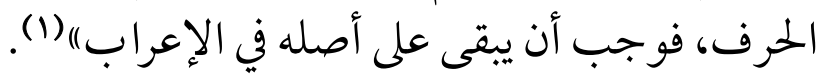

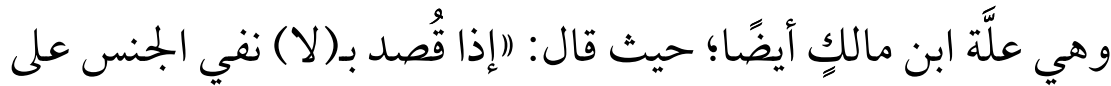

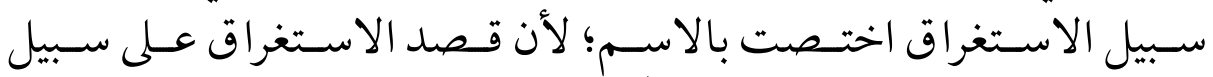

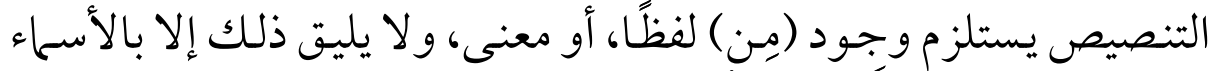

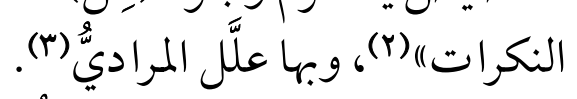

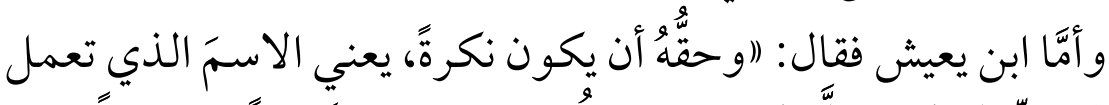

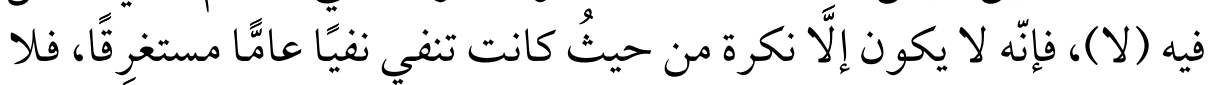

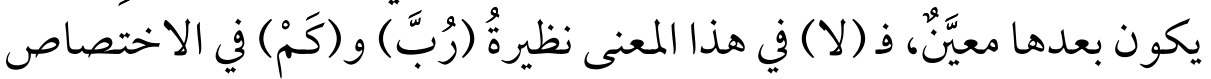

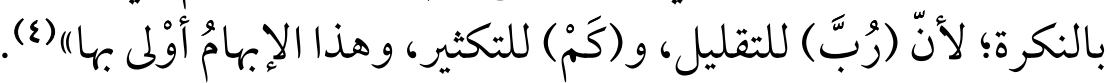

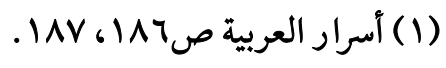

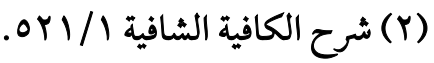

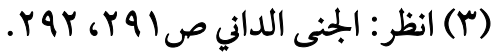

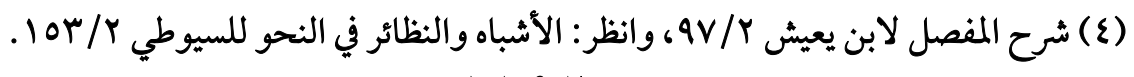




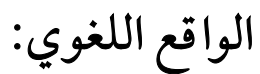

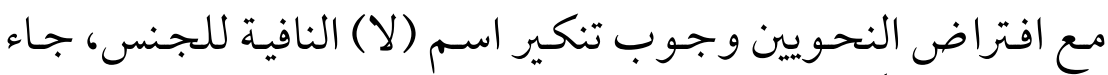

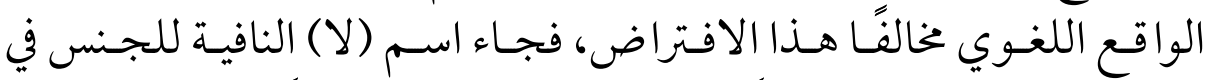

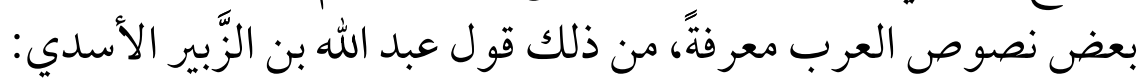

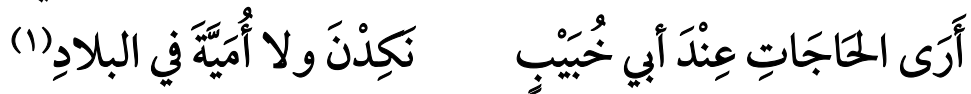

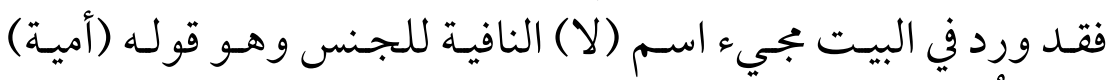

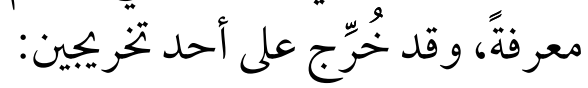

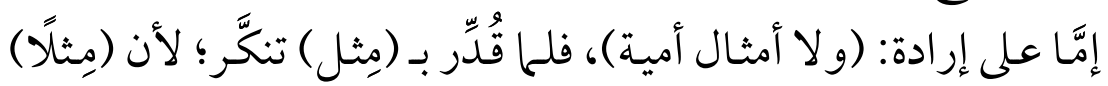
نكرة وإن أضيفت إلى معرفة (r)

وإَِّّا عـلى إرادة: (ولا أجـوادَ في الـبلاد)؛ لأن بنـي أميـة قـــ اشـتهروا

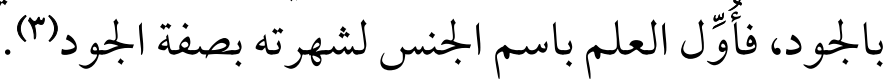
ومثله قول الشاعر:

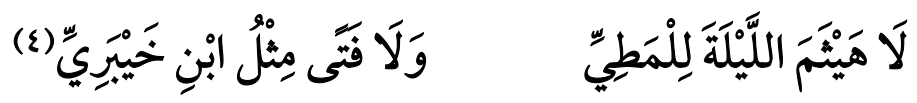

(1) سبق تخريهه، والشاهد فيه قوله: (ولا أميّة)؛؛ حيث وقع اسم (لا) النافية للجنس معرفة، والتقدير

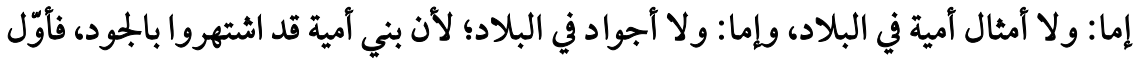

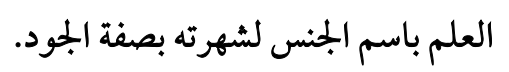

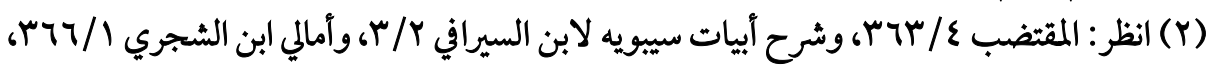

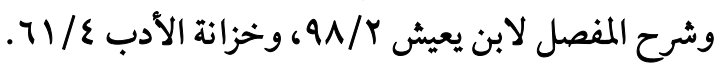

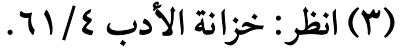

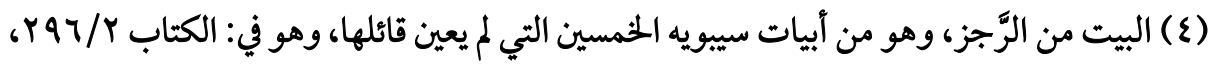

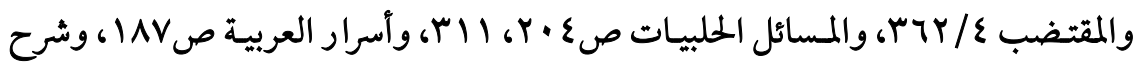

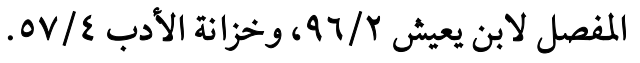

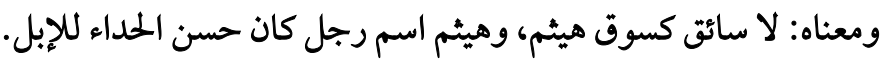

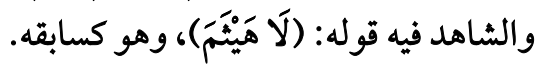


فجاءً اسـم (لا) النافية للجنس وهو قوله (هيثم) معرفة، وقد خرج

$$
\text { على أحد تخريجات: }
$$

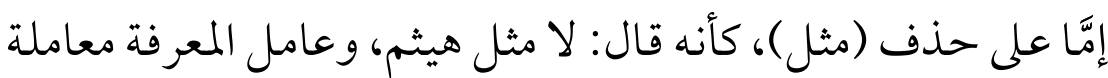

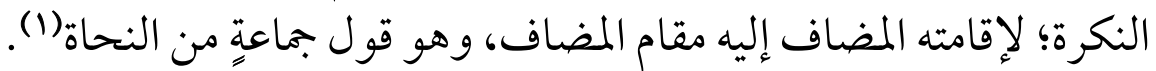

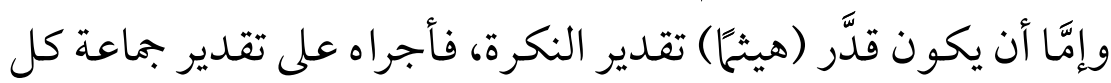

$$
\text { واحد منهم هيثم، ونفي ذلك. }
$$

و الفرق بينها في حقيقة معنى اللفظ أن نفي مثله لا يوجب دئ نفيه، وإنها

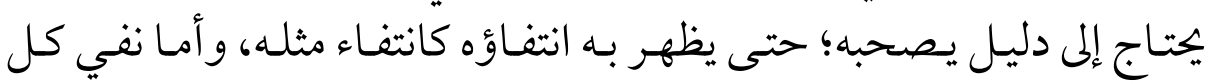

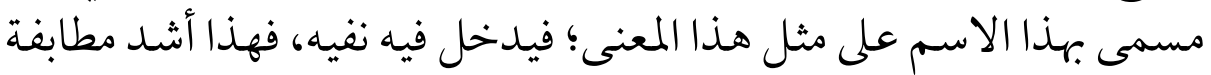

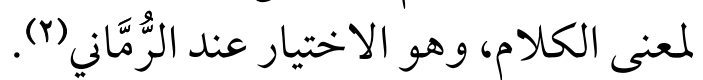

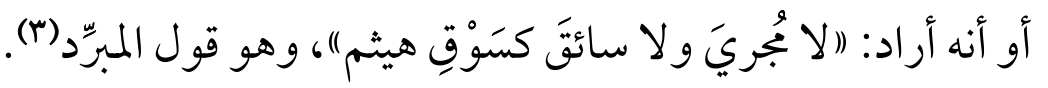

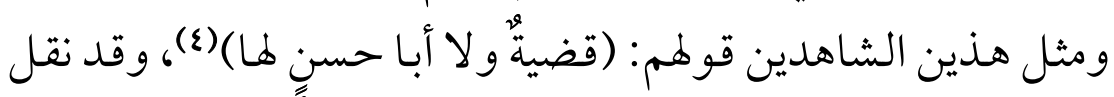

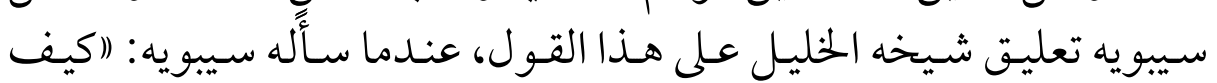

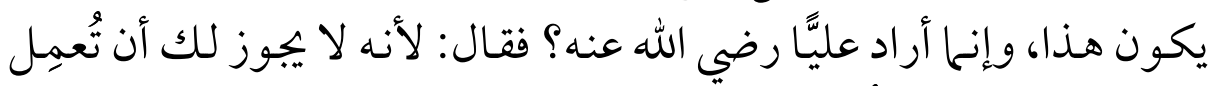

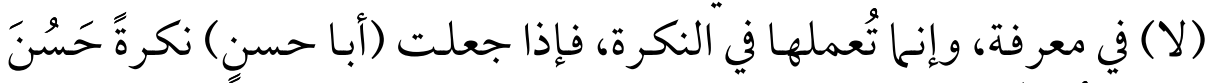

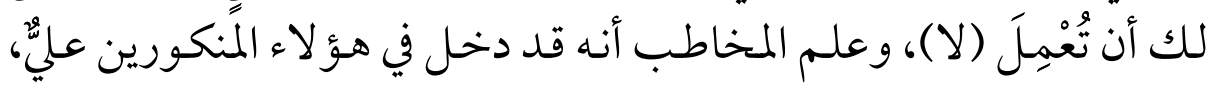

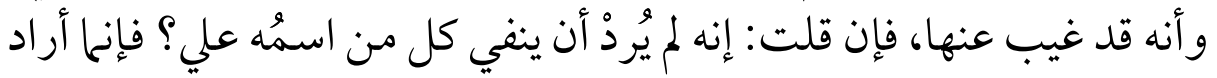

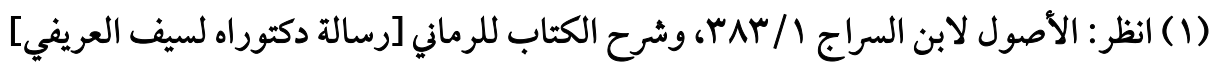

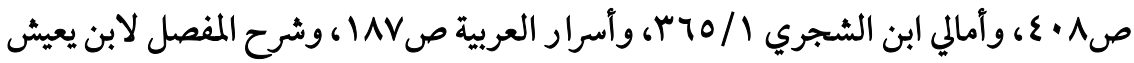
$.17 r / 4$

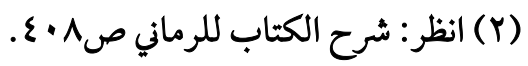

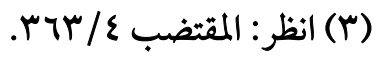

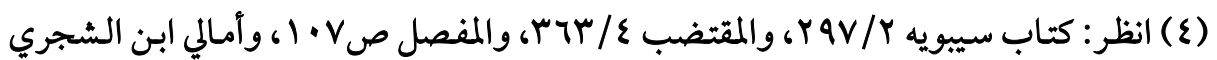

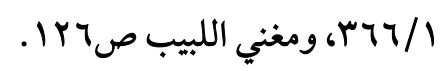




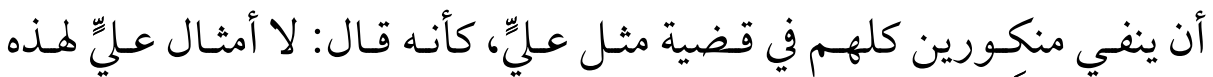

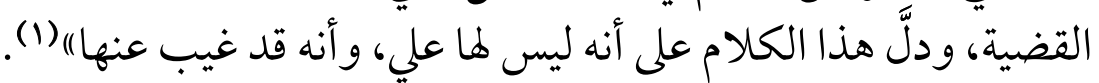

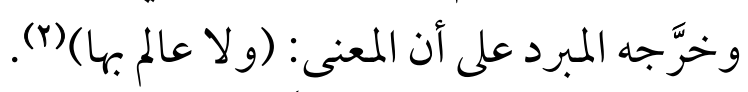

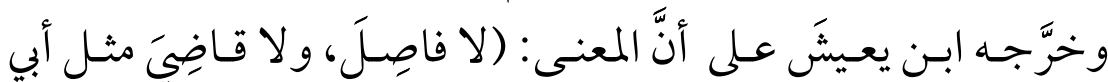

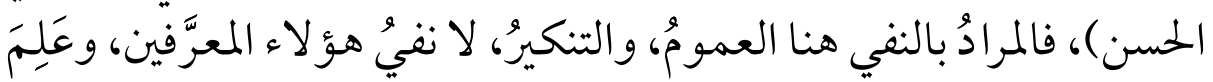

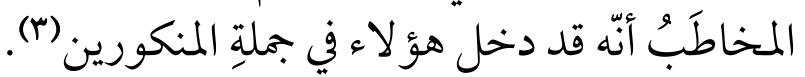

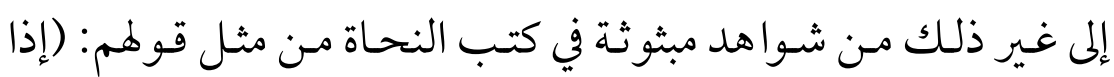

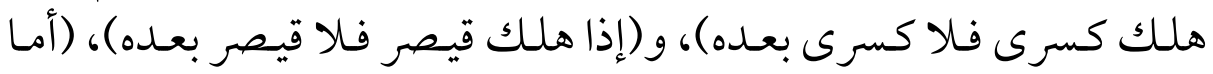

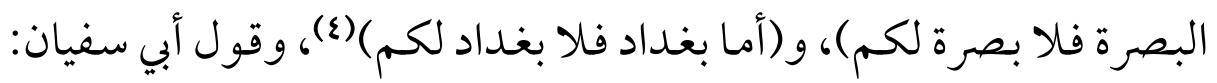

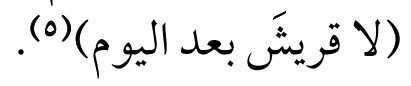

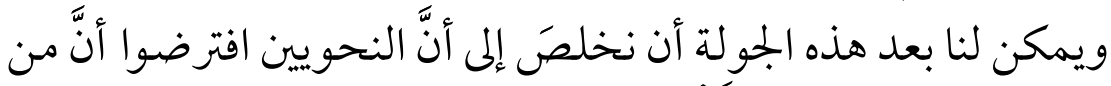

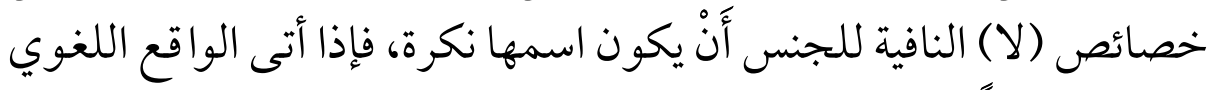

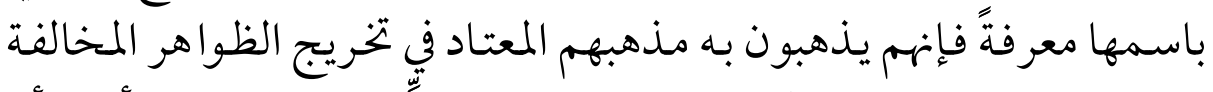

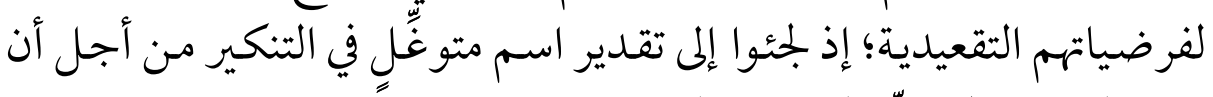
يبقى التركيب في حيّز الفرضية المقررة.

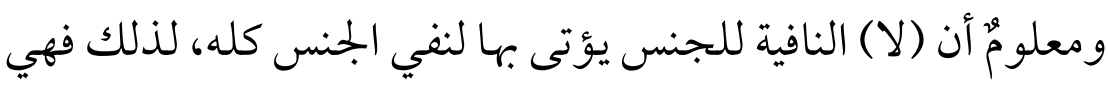

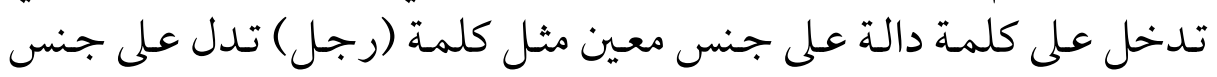

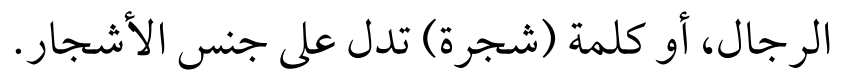

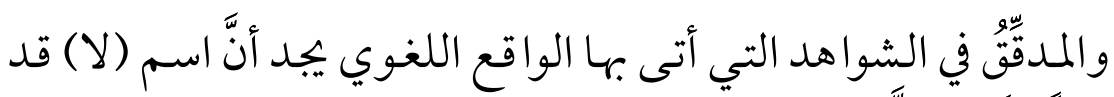

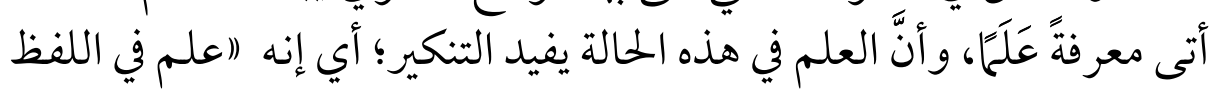

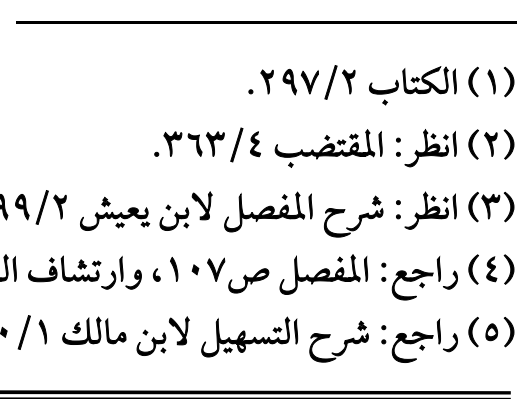


والشكل)"، ((نكرة في الدَّلَالَة))؛ إذا إنها معارف شائعة مشهورة في اختصاصها

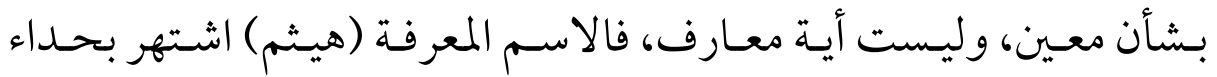

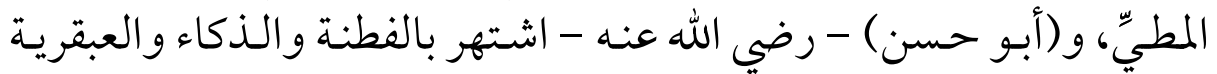

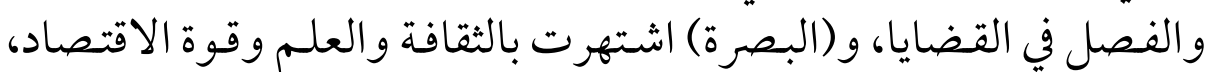

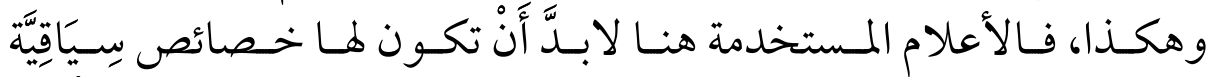

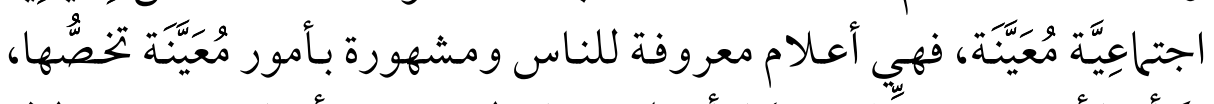

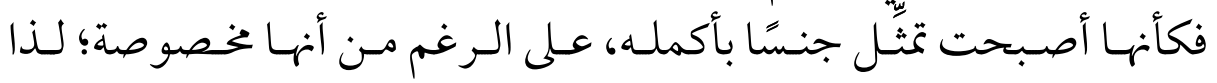

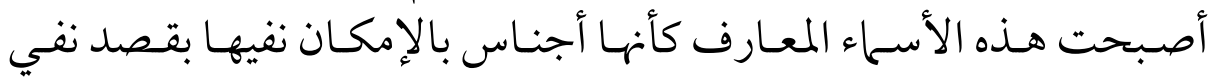

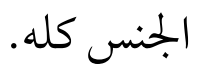

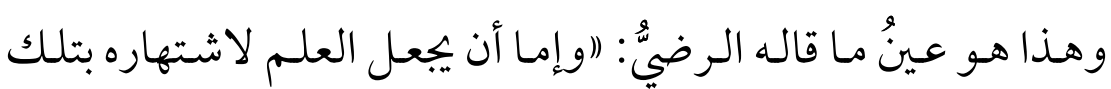

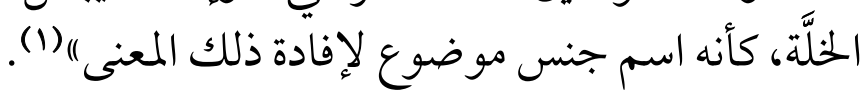

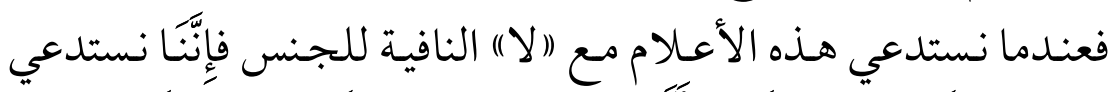

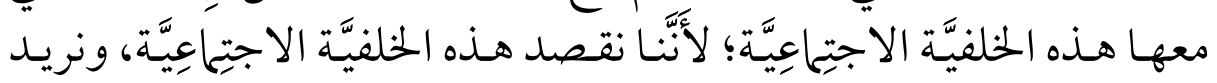

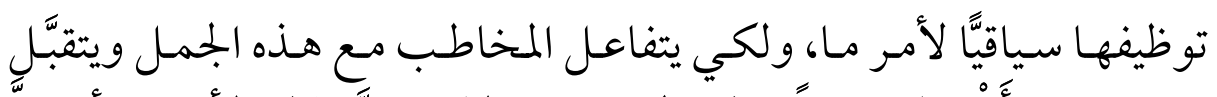

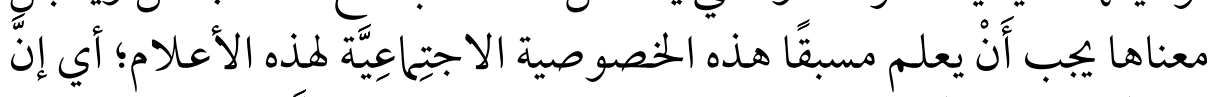

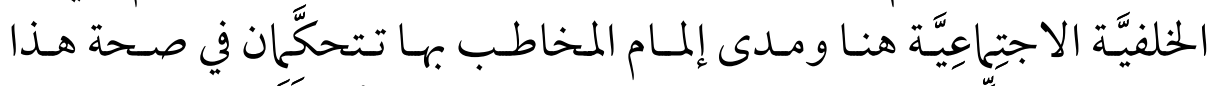

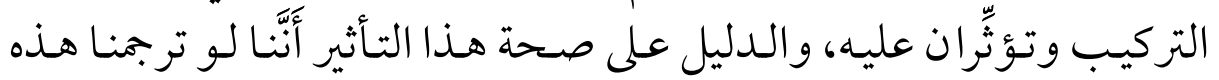

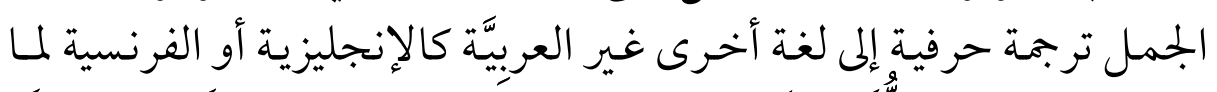

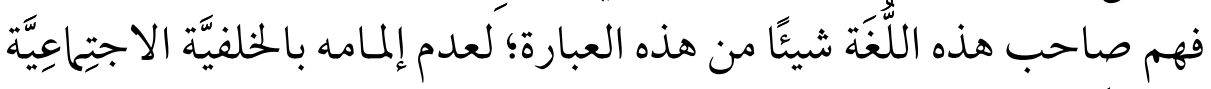
السِّياقِيَّة لها.

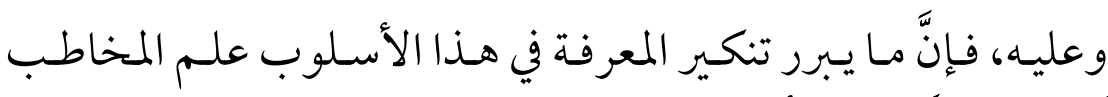

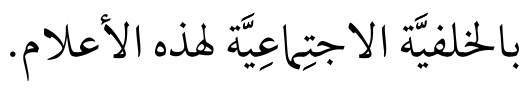

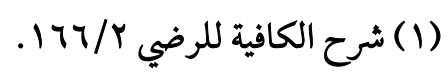




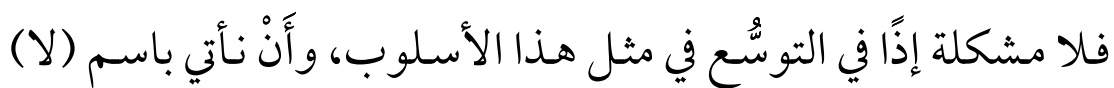
النافية للجنس معرفة بشرطين:

\section{• أَنْن يكون عَلَلًَا.} وأَّْْ يكون هذا العلم مشهورًا معروفًا عند عامة الناس.

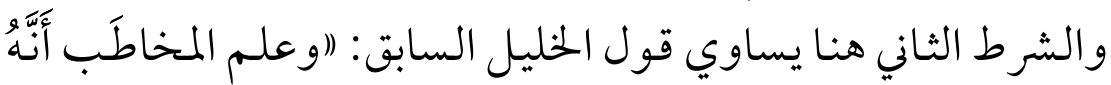

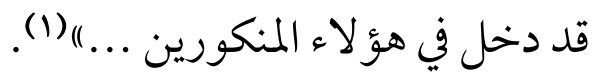

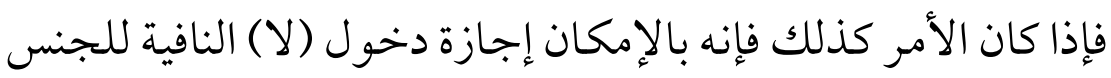

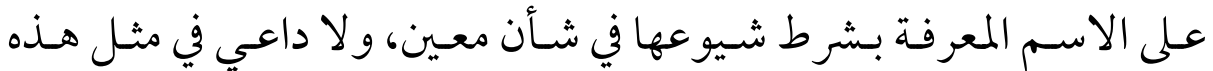

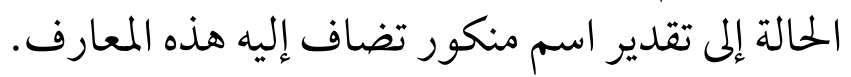

يزيد على ذلك أن الكسائي أجاز إعلال (لا) النافية للجنس في العلم

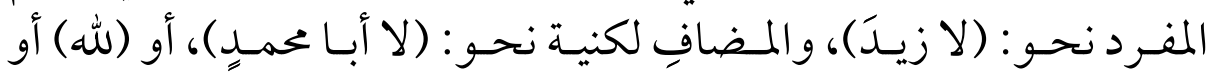

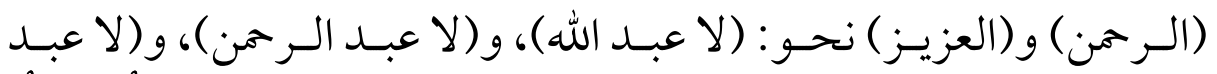

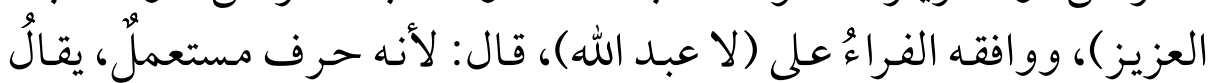

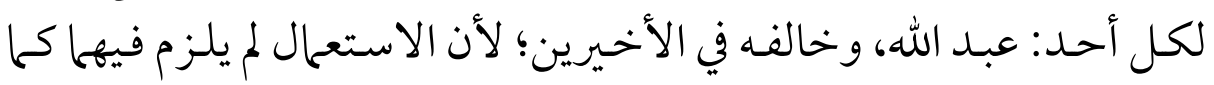

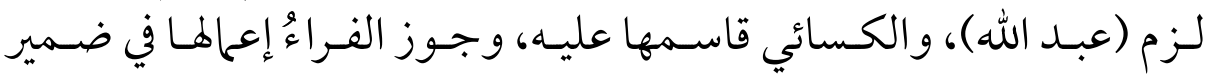

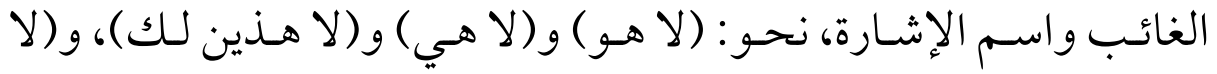
هاتين لك)(r) 


\section{رؤية البحث:}

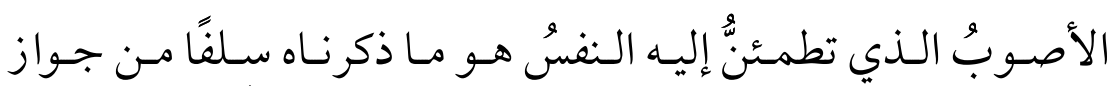

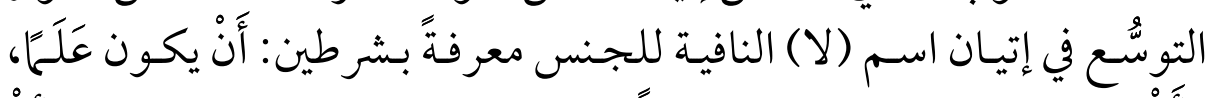

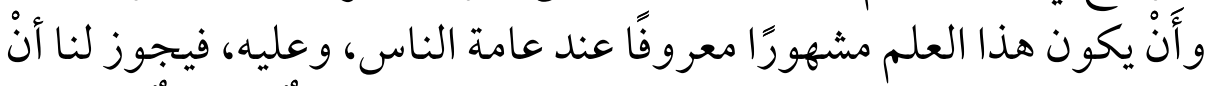

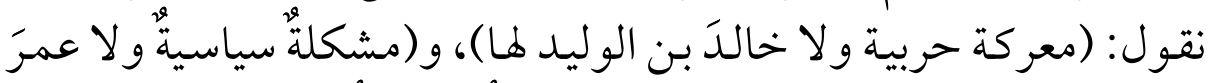

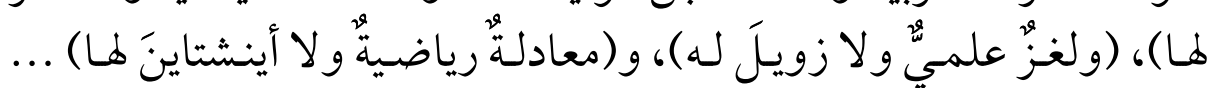

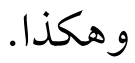




\section{الاســــ الإنسادى:}

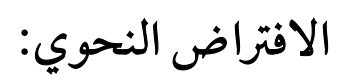

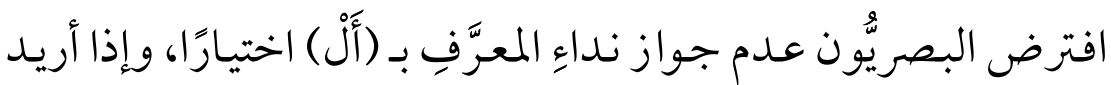

$$
\text { ذلك تُوُصِّل إليه بـ (أي) أو (هذا)(1). }
$$

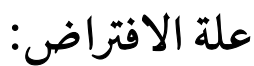

$$
\text { وقد علَّلّوا لصحَّة افتراضهم هذا بت بتعليلين: }
$$

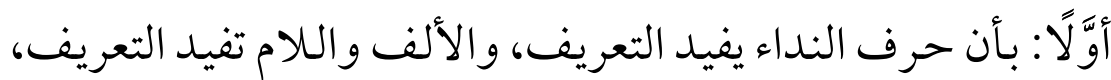

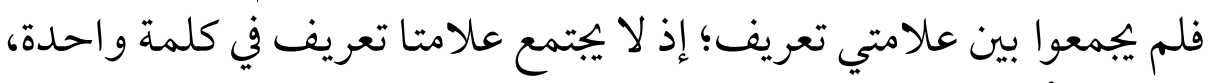

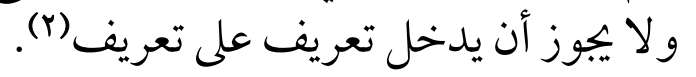

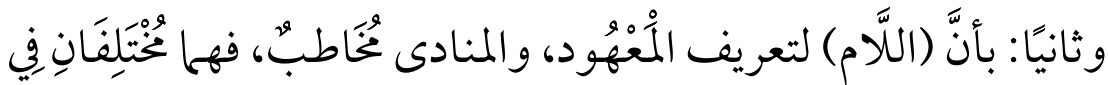

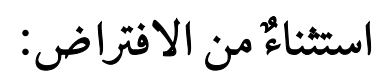

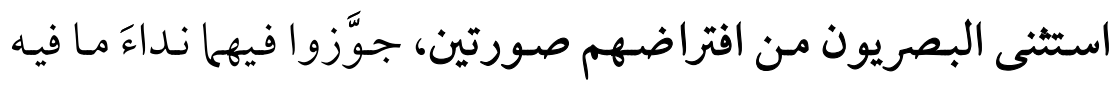

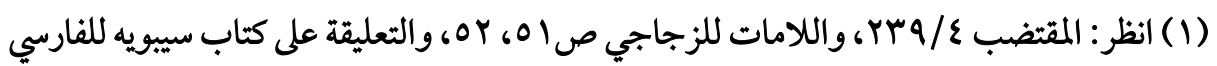

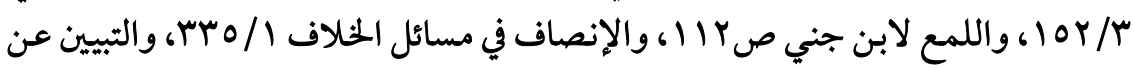

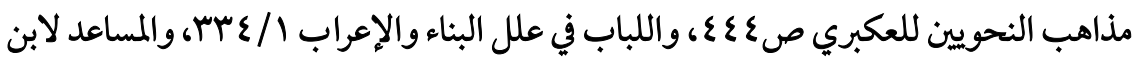

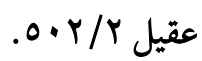

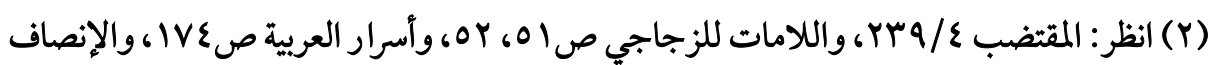

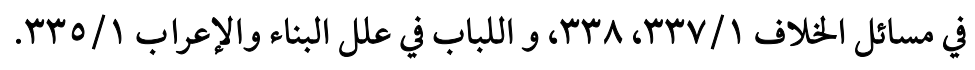

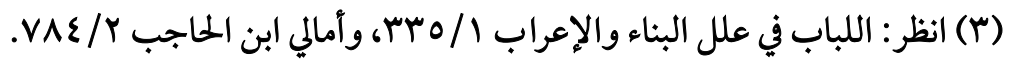

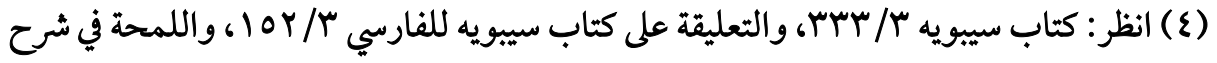

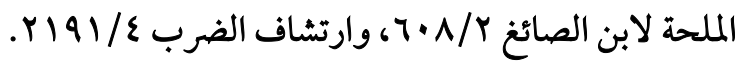




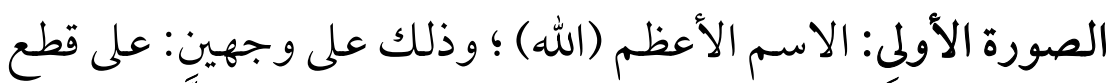

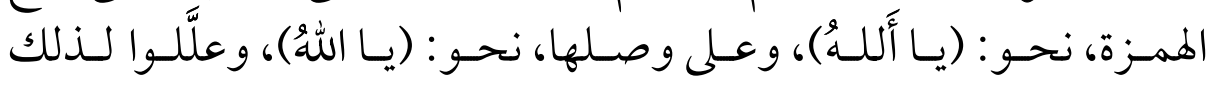

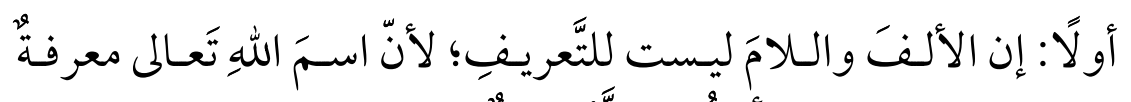

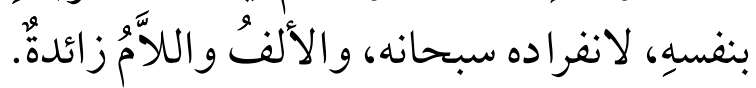

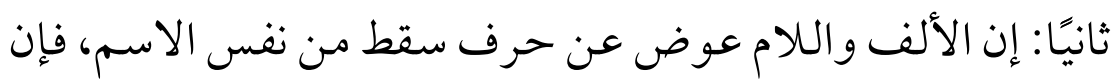

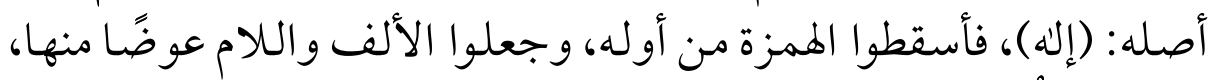

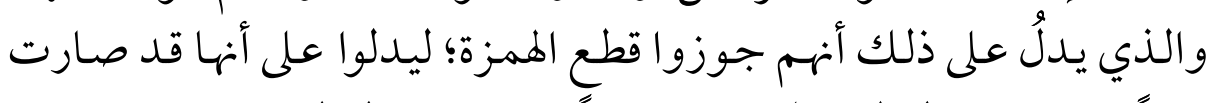

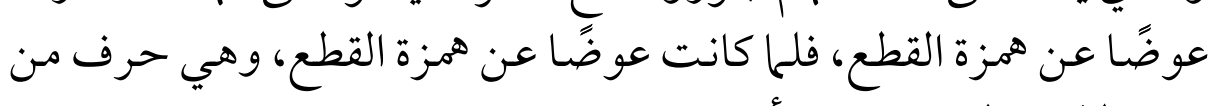

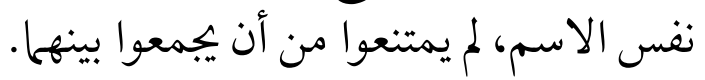

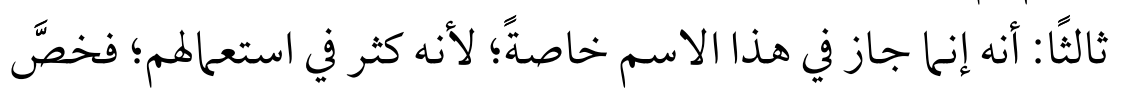

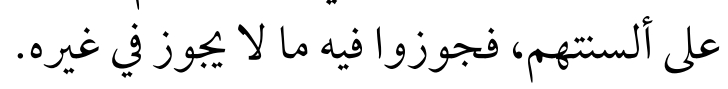

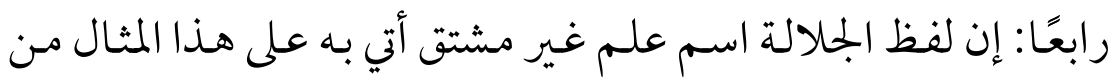

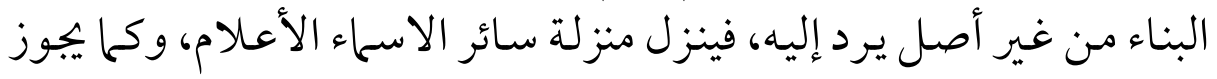
دخول حرف النداء على سائر الأسماء الأعلام فكذلك ها ها هنا.

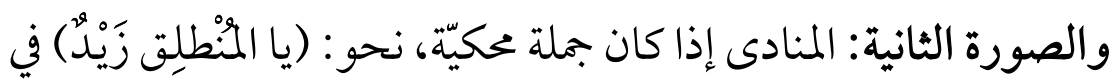

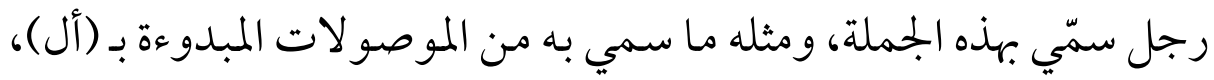

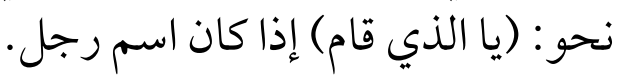

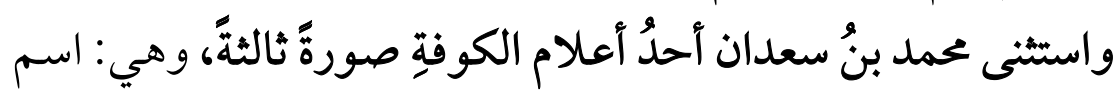

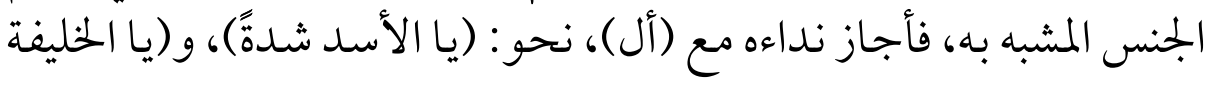

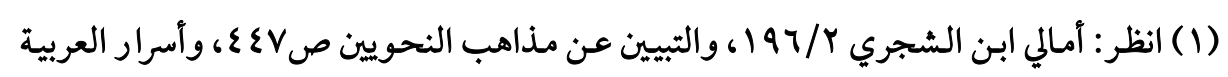

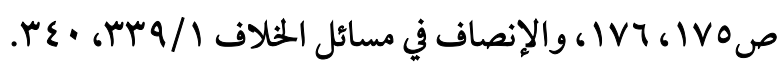


جُودًا)، ووافقه ابن مالك؛ لأن تقديره: (يا مثل الأسد)، و(يا مثل الخليفة)، (القال

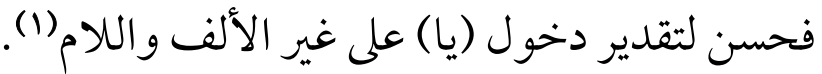

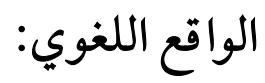

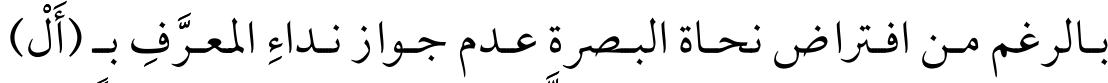

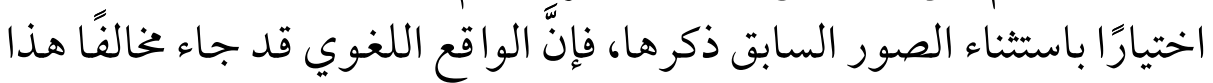

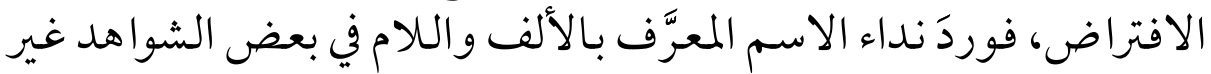

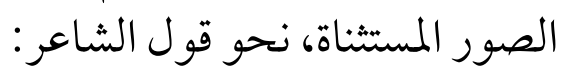

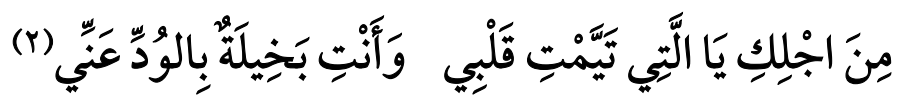

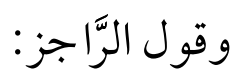

فَيَّا الغُلاكَمَانِ اللَّذّانِ فََّّا

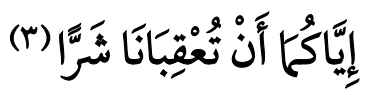

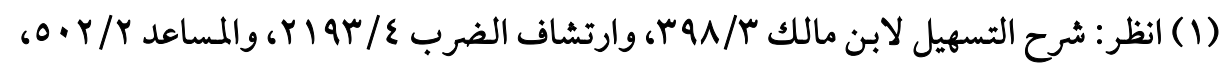

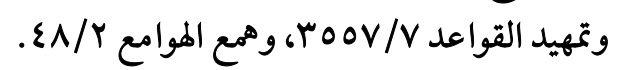

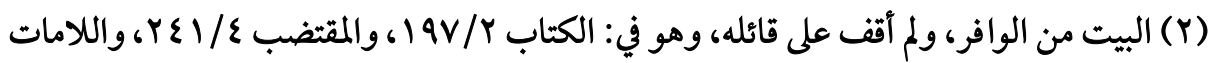

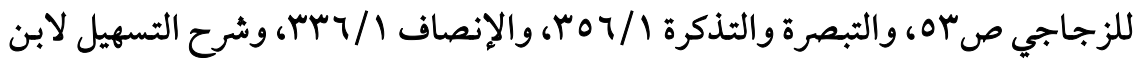

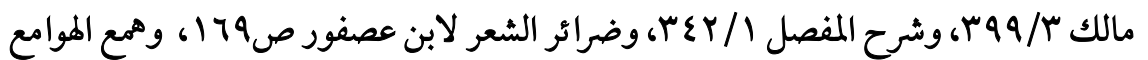

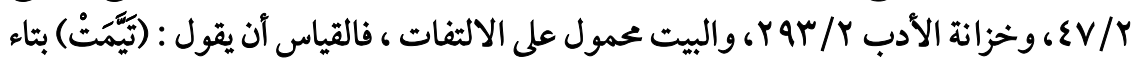
التأنيث على الغيبة ، وفيه عدة روايات لا تغير معالم الاستشهاد بهاديه.

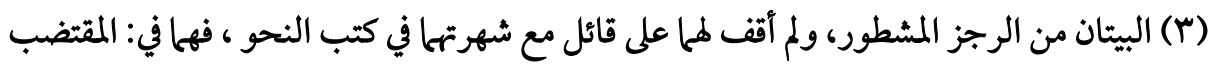

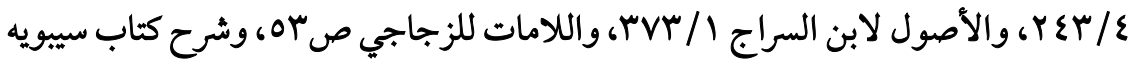

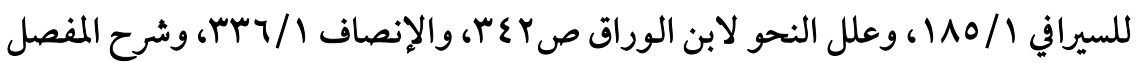

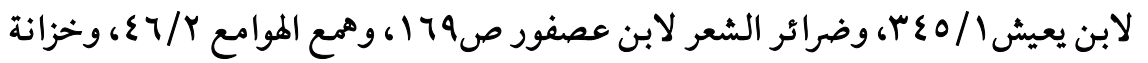

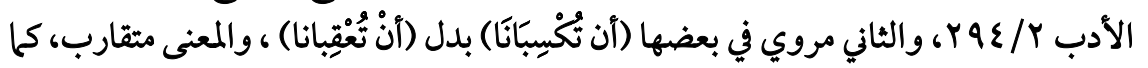

يروى : (إياكما أن تكتحاني سِرَّا ) أي : أمرَا خفيًّا. 


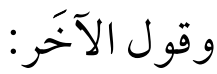

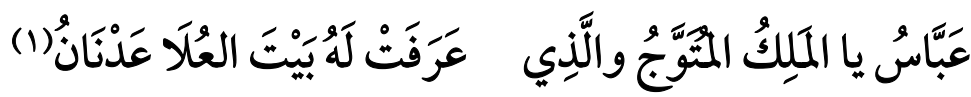

$$
\text { تخريج البصريين للشواهد: }
$$

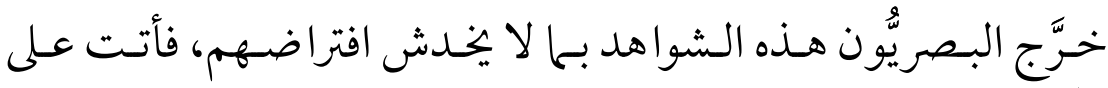

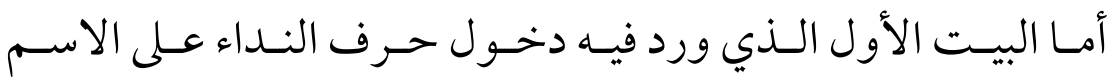

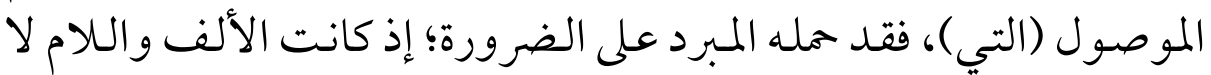

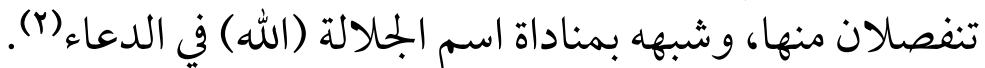

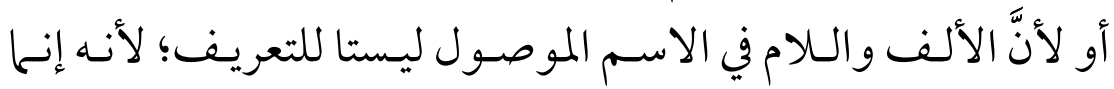

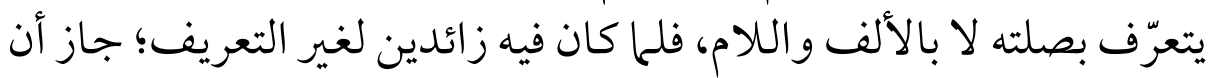

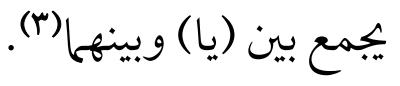

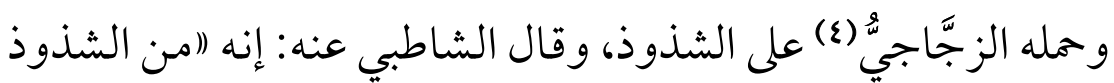

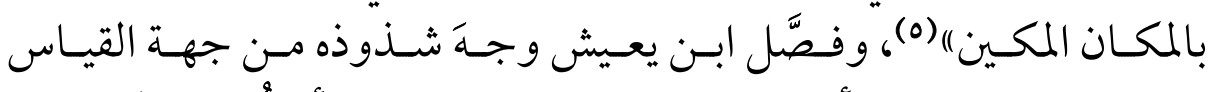

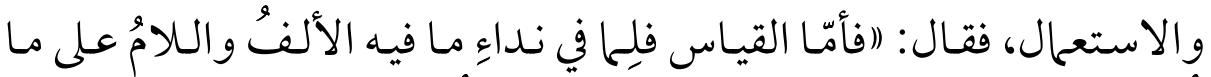

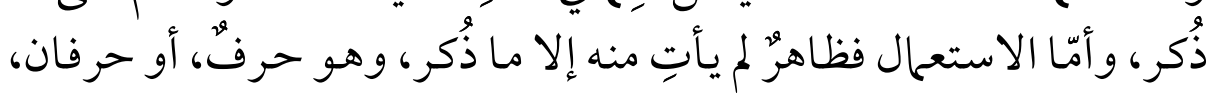

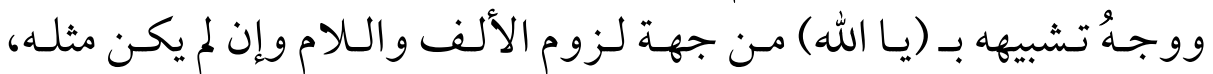

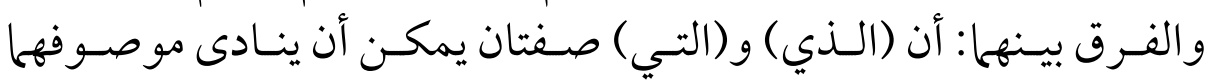

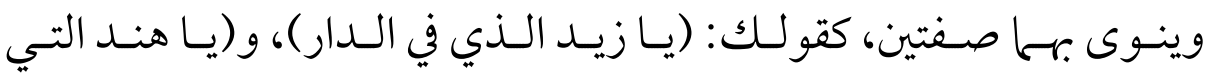

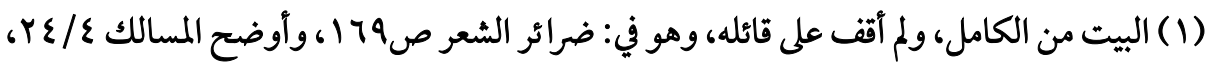

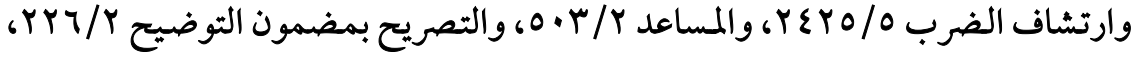

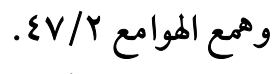

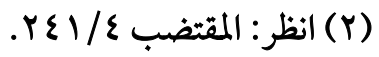

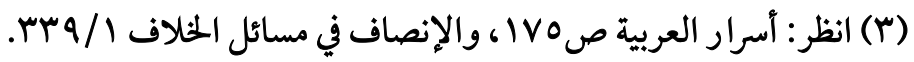

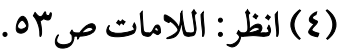

(0) (8) المقاصد الشافية PMN/0. 
أكرمتني) ... وليستا اسمين ولا يكون ذلك في اسم (الله) تعالى؛ لأنه اسم (عم اسم

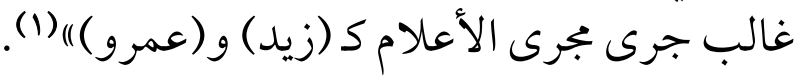

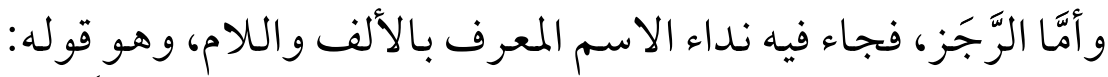

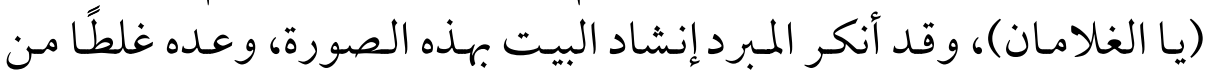

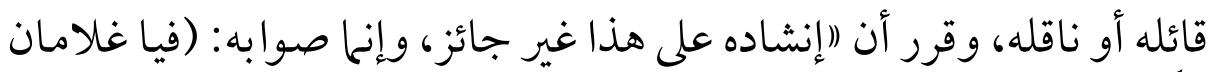

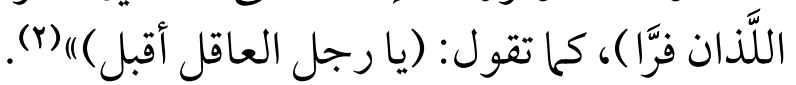

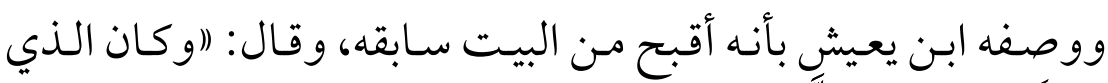

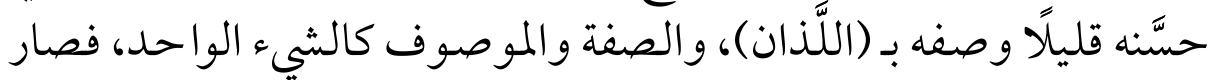
حرف النداء كأنه باشر اللذان)|(r).

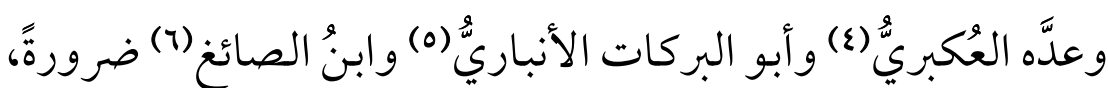

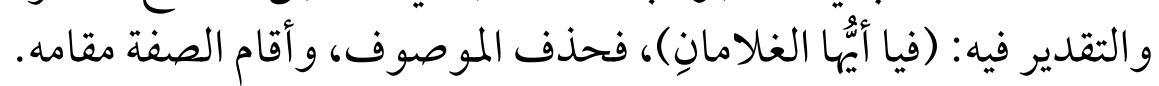

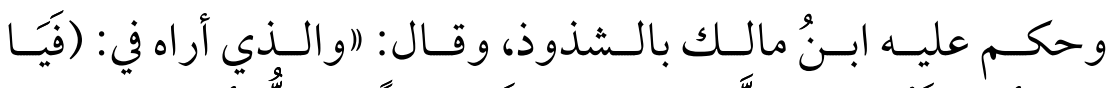

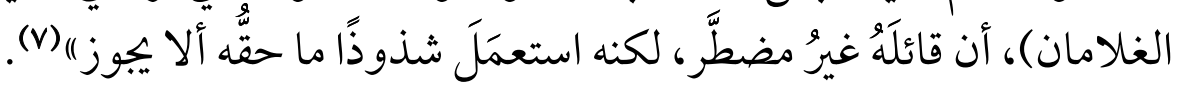

$$
\begin{aligned}
& \text { (1) شرح المفصل لابن يعيش / / / ع r. }
\end{aligned}
$$

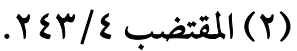

$$
\begin{aligned}
& \text { (Y) شرح المفصل / / / }
\end{aligned}
$$

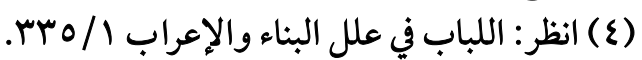

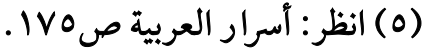

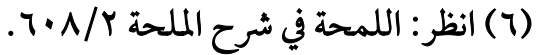

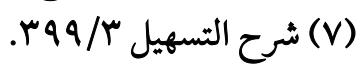


و أمَّا البيت الثالث، فعدَّه البصريون(1) و وابن هشام(r) و الشيخ خالد

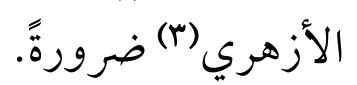

\section{موقف الكوفيين والبغداديين من القضية:}

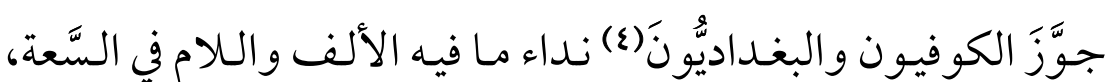

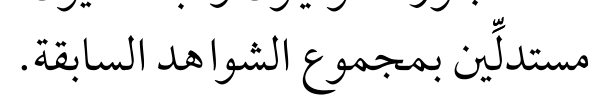

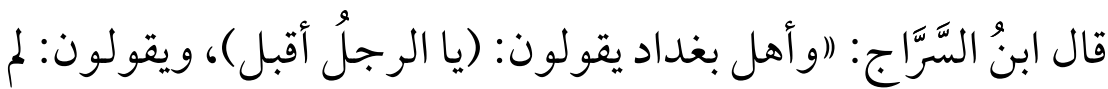

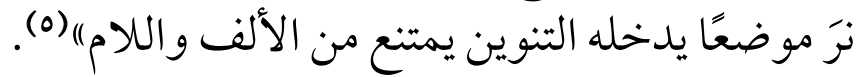

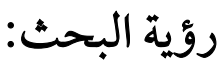

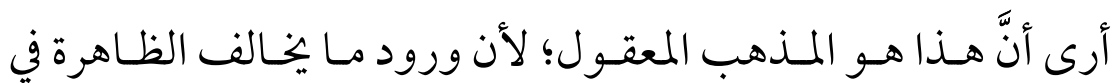

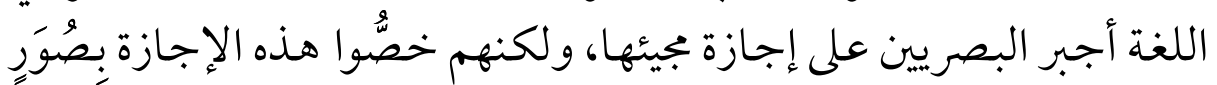

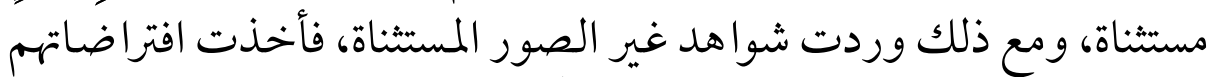

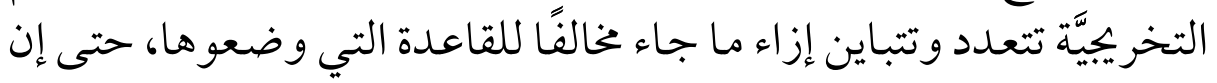

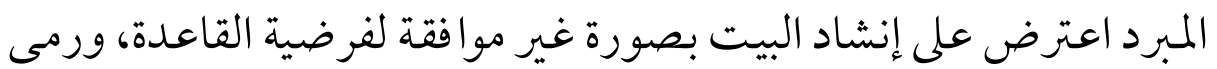
قائله بالغلط.

ثم نرى ابن يعيش يقول في (فَيَّا الغُلامانِ): الو كان الذي حسَّنه قليلًا

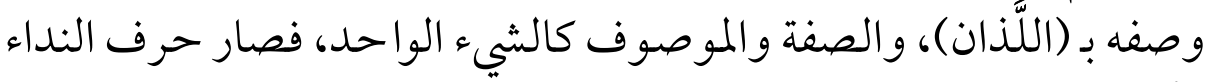

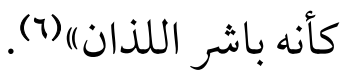

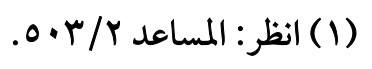

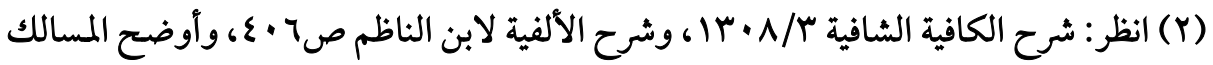

$$
\text { .r } \varepsilon / \varepsilon
$$

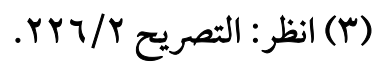

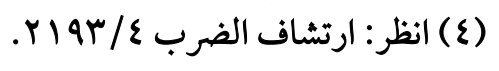

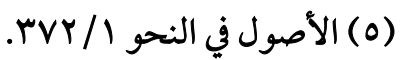

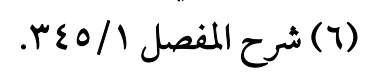


وكذا نرى الرضيَّ يقول في (يَا التّيَي): (اووجه جوازه مع الشذوذ لزوم

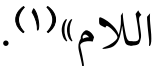

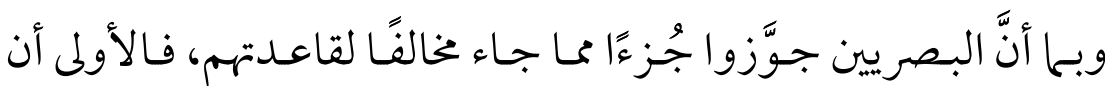

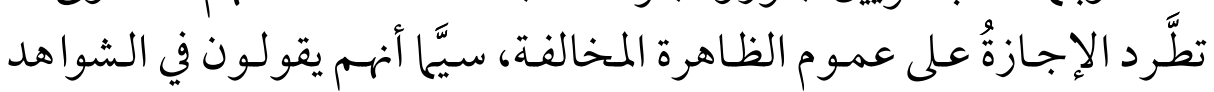

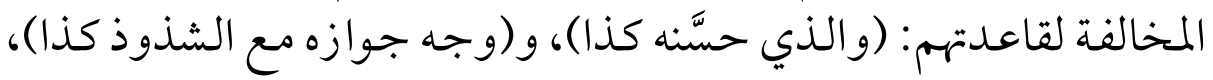
و هذا ما فعله الكوفيون والبغداديون. والبهن 


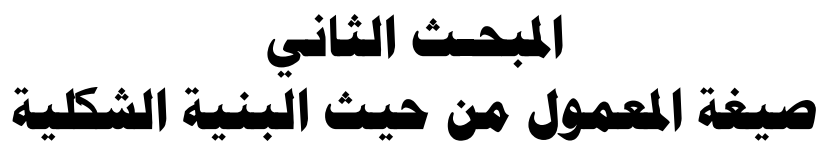

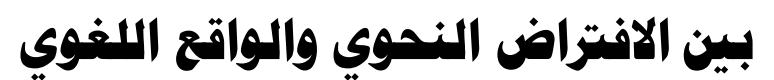

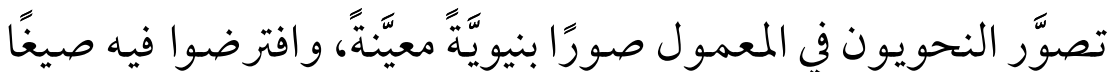

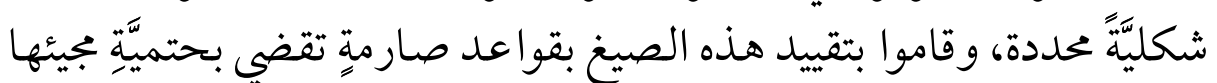

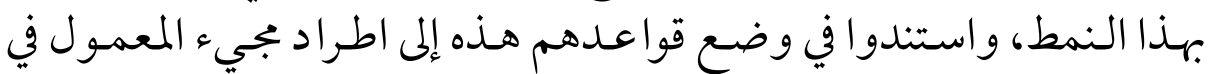

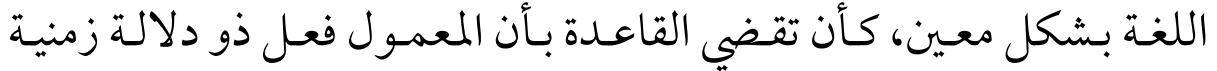

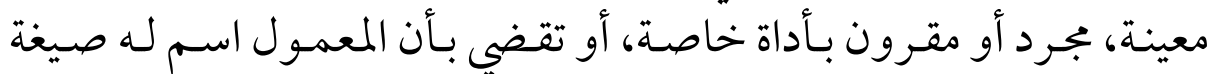

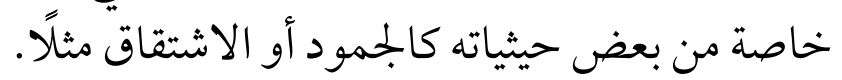

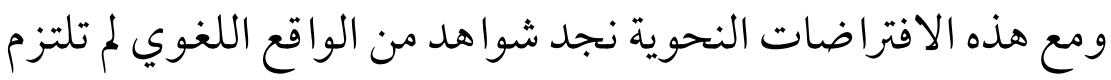

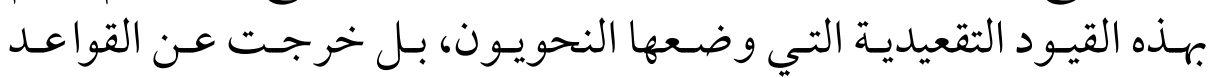

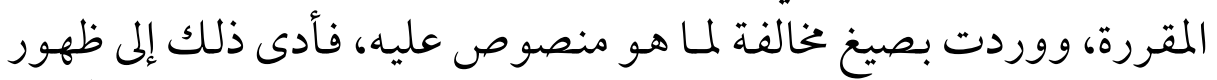

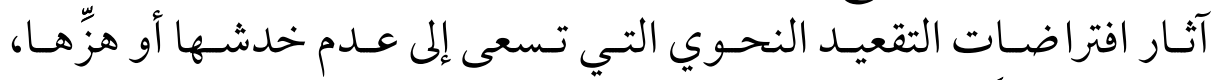

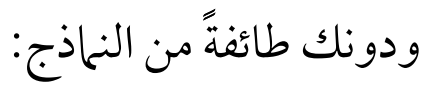

\section{بنية أخبـار أفعال المقاربة:}

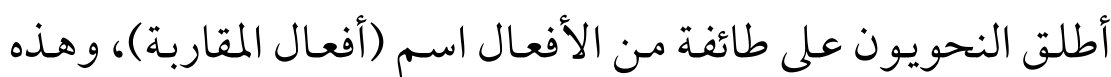

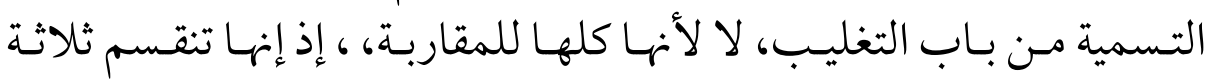
أقسام : التمد

الأول : ما يدل على المقاربة، وهي: (كاد، وكرَبَ، وأوشك).

الثاني : ما يدل على الرجاء، وهي: (عسى، وحرَى، و واخلولقي).

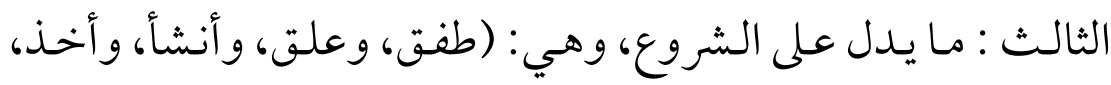


فتسميتها (أفعال المقاربة) من تسمية الكلّ باسم الجزء(1).

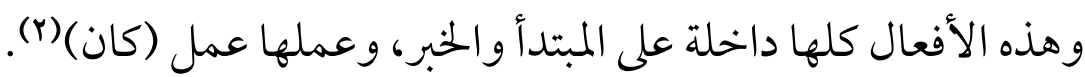

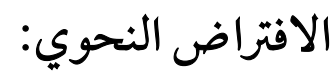

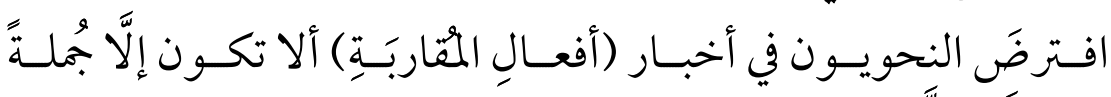

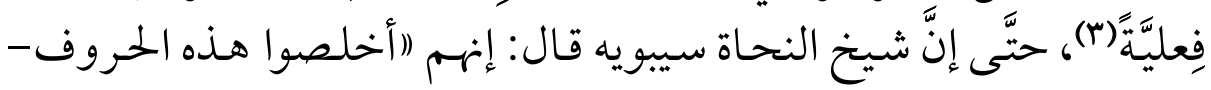

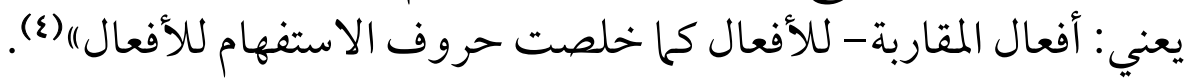

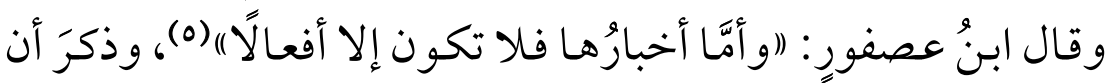

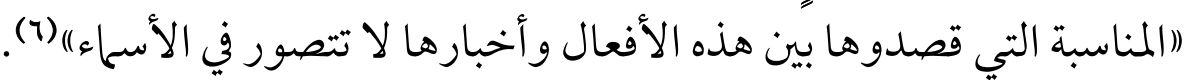

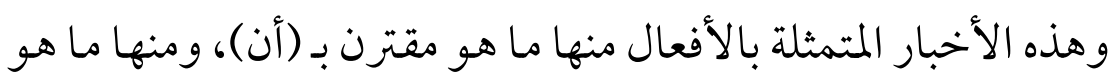

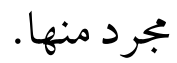

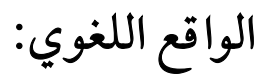

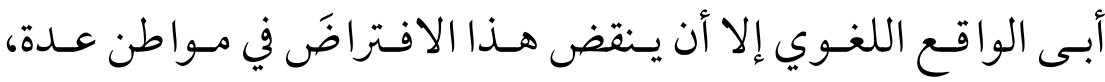

وتفصيلها كالآتي:

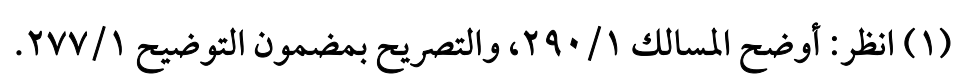

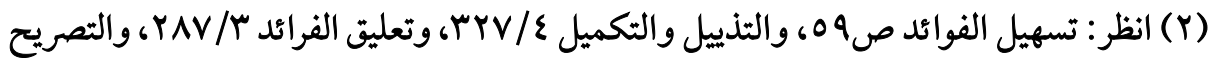

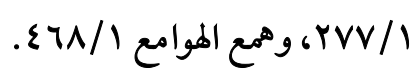

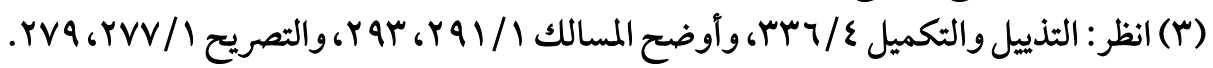

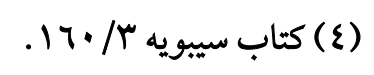

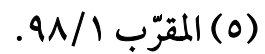

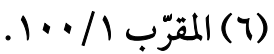




\section{بنسية خبر (كاد):}

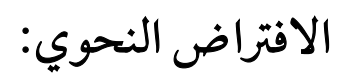

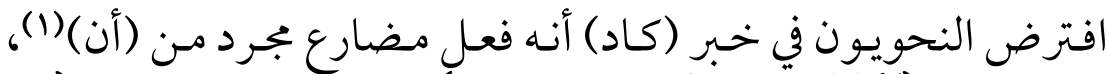

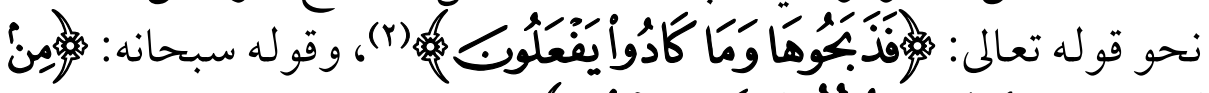

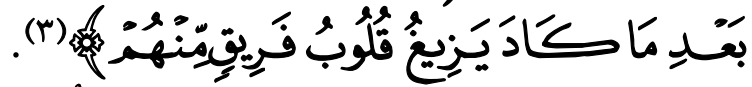

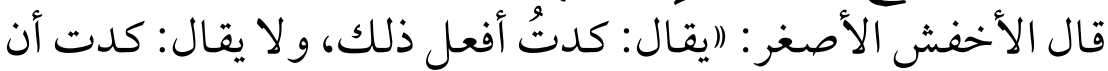

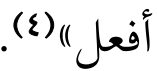

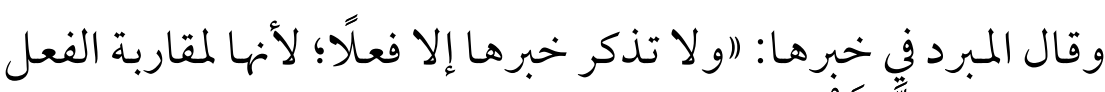

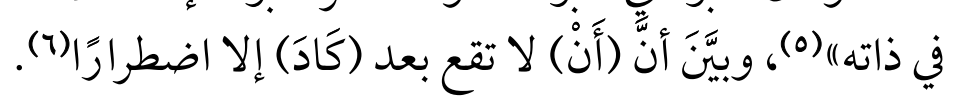

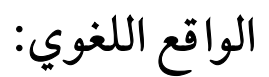

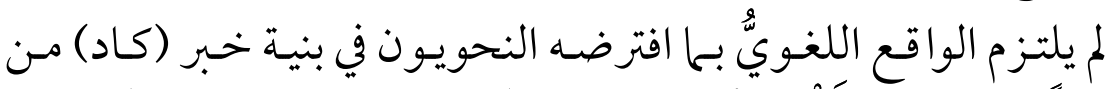

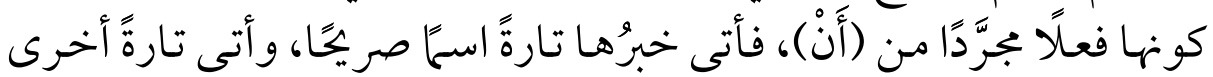
فعلًا مقترنًا بـ (أَنْ)ُ.

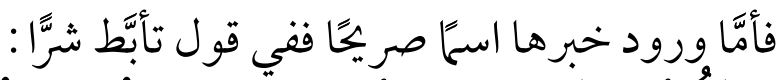

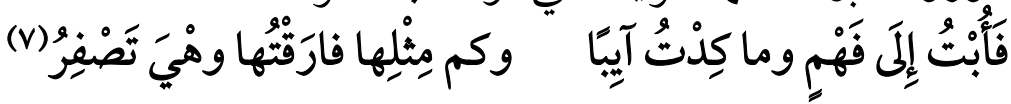

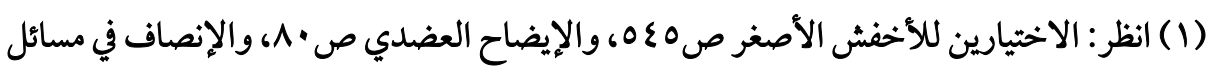

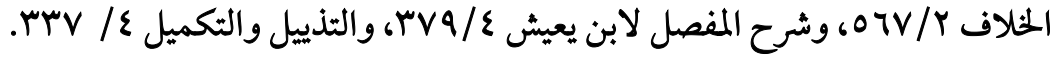

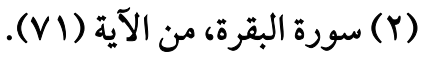

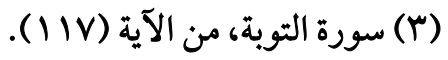

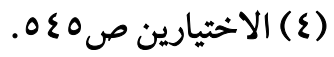

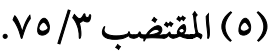

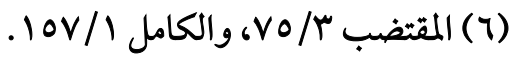

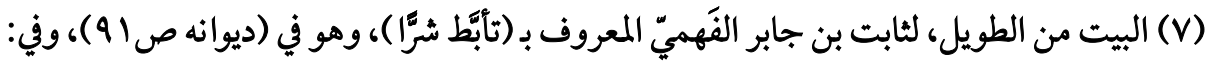

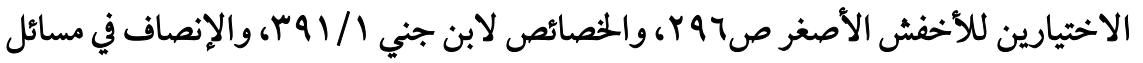

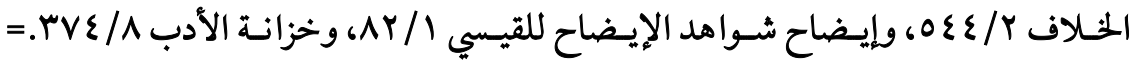


ومع هذه المخالفة لافتراض النحويين، إلا أنهم أجمعوا على أنَّاستعمال

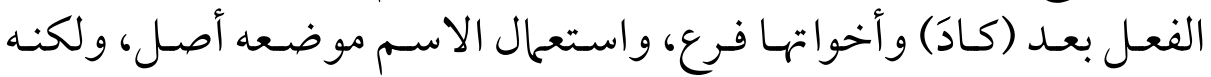

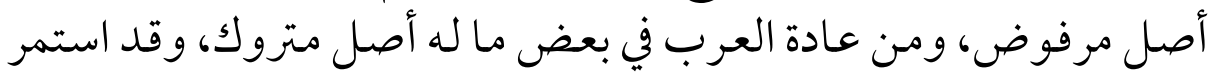

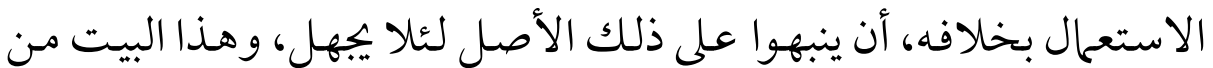

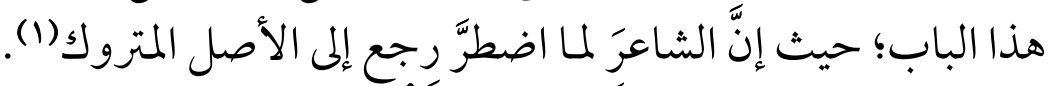

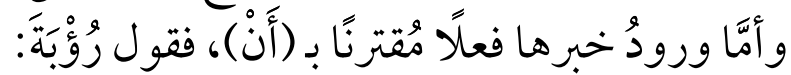

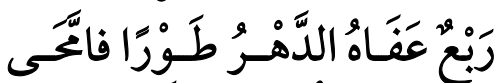

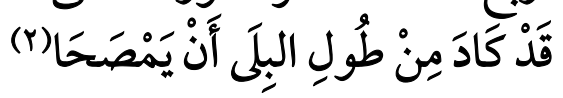

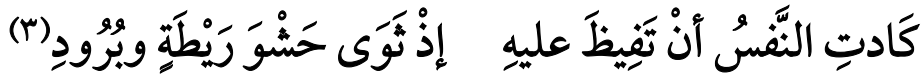

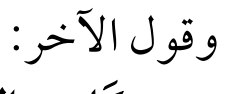

= و (أُبْتُ): رجعت، و(فَهْم): أبو قبيلة، وهو فهم بن عمرو بن قيس بن عيلان، و(تَصْفِر ) من صفر الطائر. والمعنى: فرجعت إلى القبيلة المسلمة بفهم، وما كدت راجعَا، وكم مثل هذه القبيلة فارقتهاوهي تصفر.

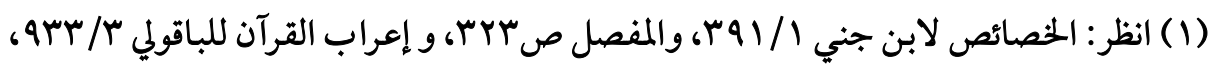

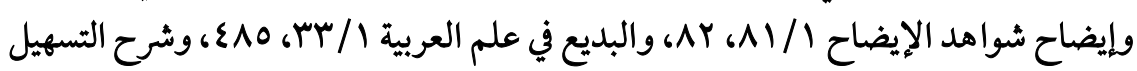

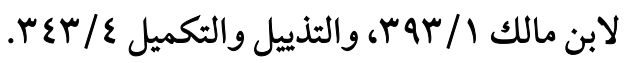

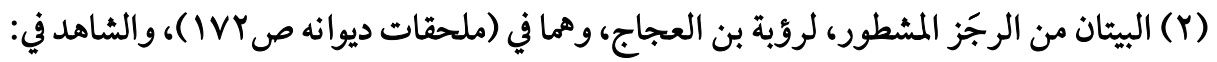

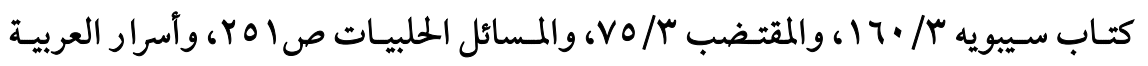

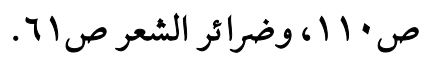

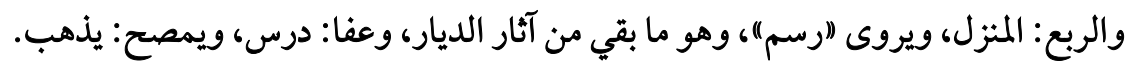

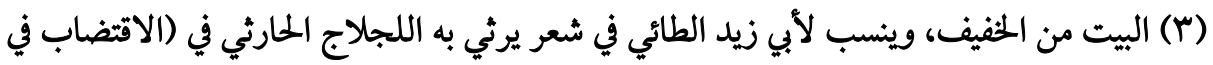

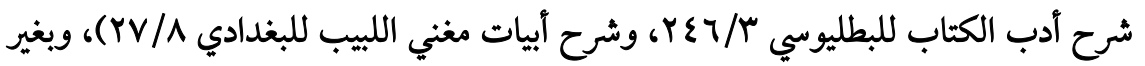

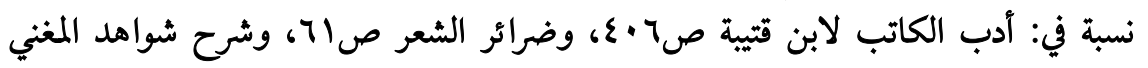

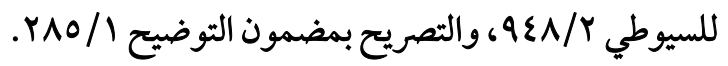

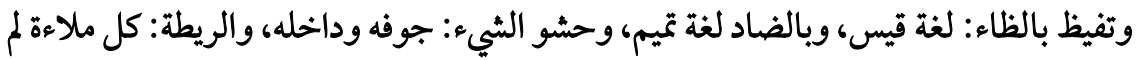
تكن من لفقين، والبرود: ثياب تصبغ باليمن، والمراد بها الكَفَّن. 


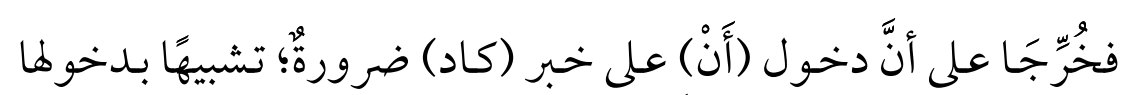

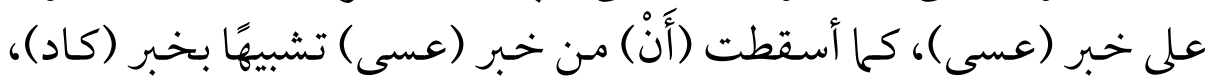

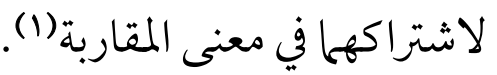

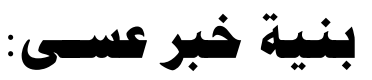

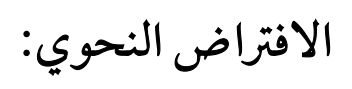

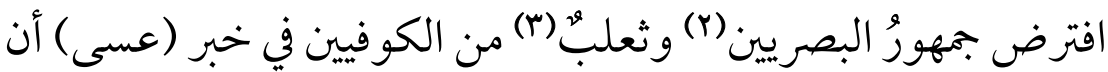

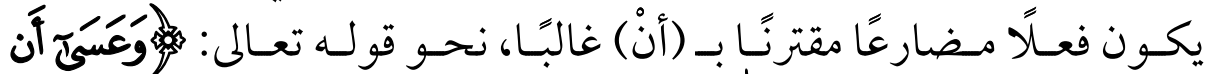

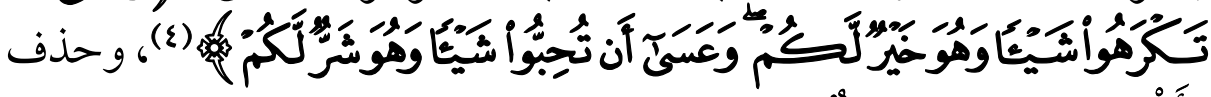

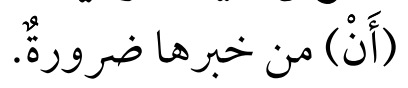

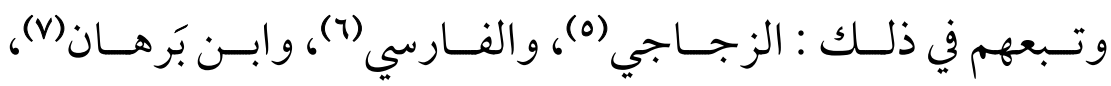
وغيرهم. علة الافتراض: وقد علَّلّوا لصحَّة افتراضهم هذا بوجوه:

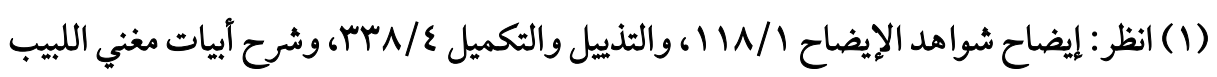

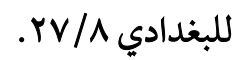

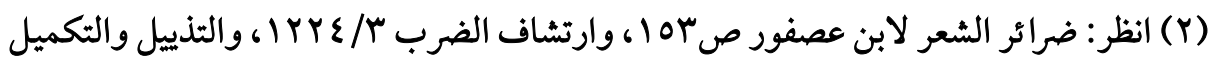

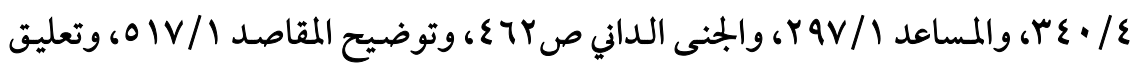

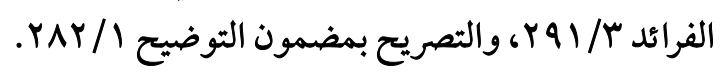

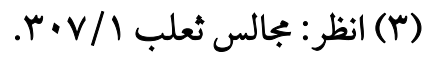

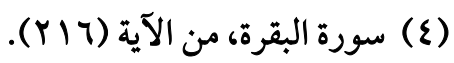

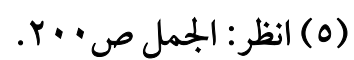

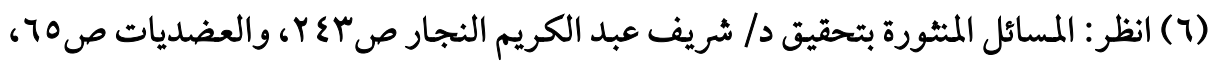

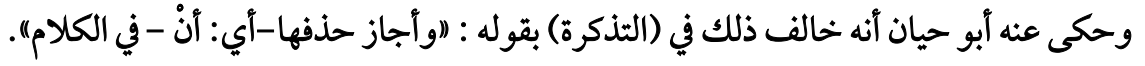

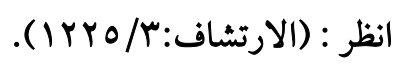

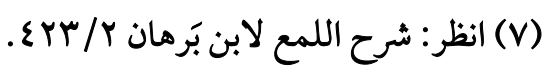




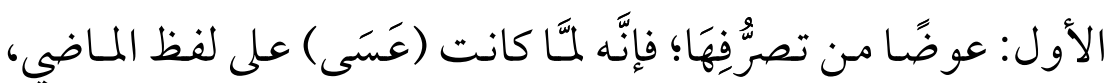

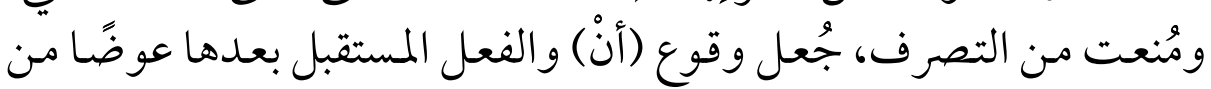

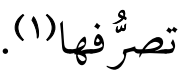

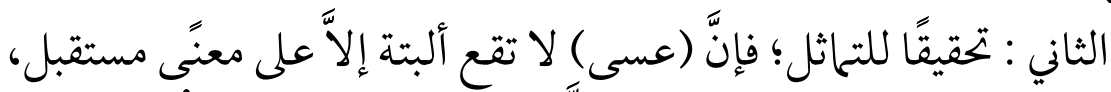

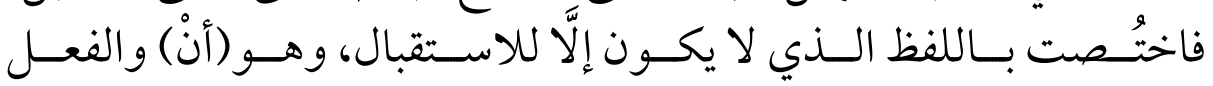
المضارع) فاختحن. الثالث : أن الخبر في تأويل الاسم الذي هو الأصل، و (أنْ) مع الفعل

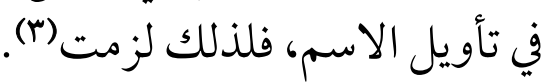

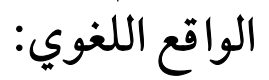

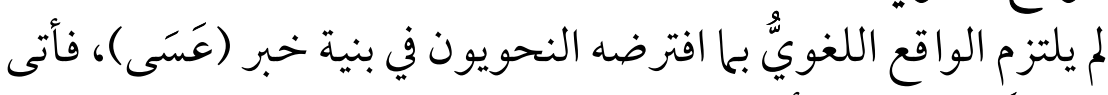

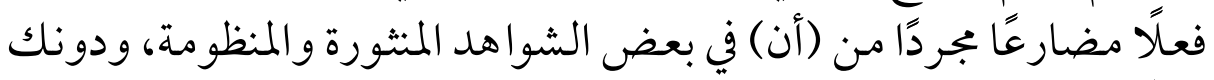
طرفًا منها:

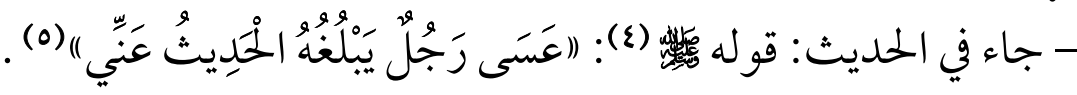

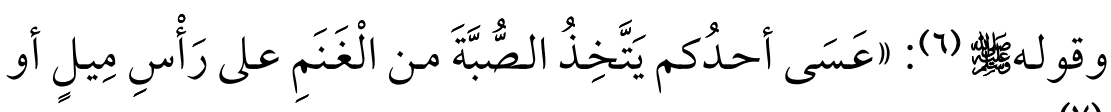
مِيلَيْنِ(v)

(1) انظر: المخترع في إذاعة سرائر النحو للأعلم الشتمري صلا ||، وشرح الدروس لابن الدهان

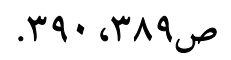

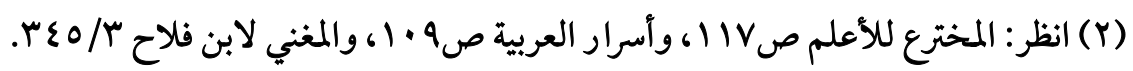

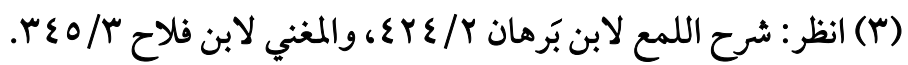

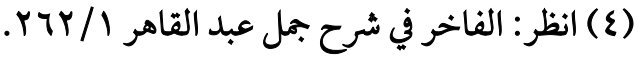

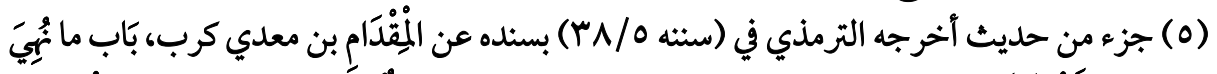

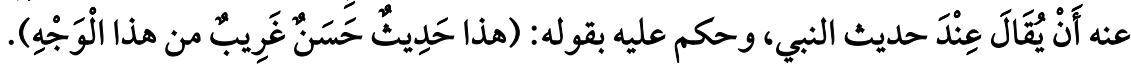

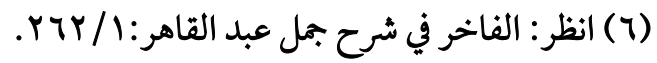

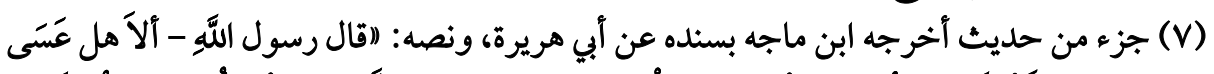

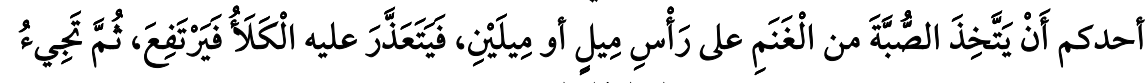




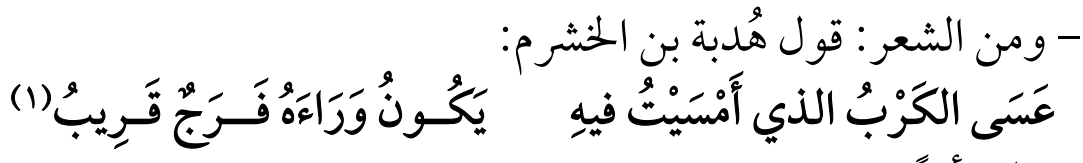
وقوله-أيضًا:

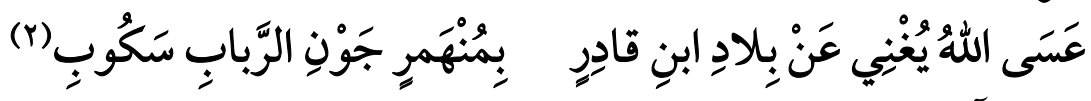

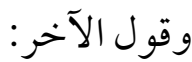

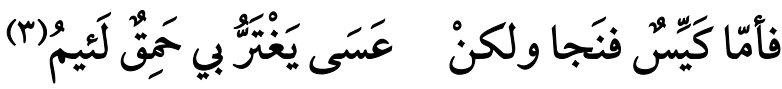

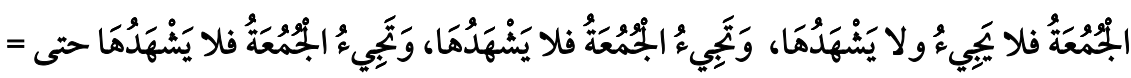

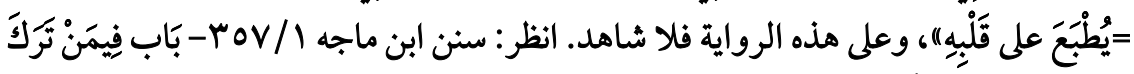

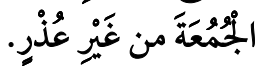
وورد بهذه الرواية، وبهذا السند في: المستدرك عل الصحيحين: / / • بع -كتاب الجمعة، وصحيح

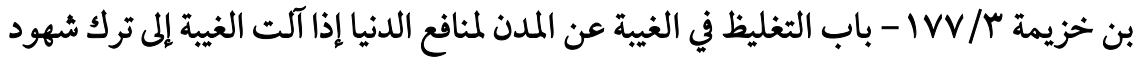

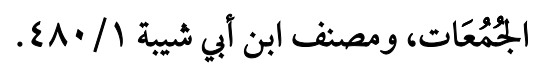

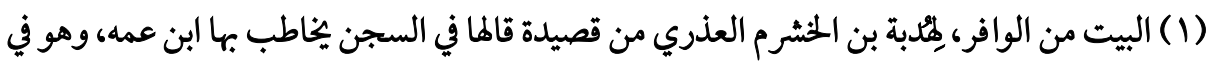

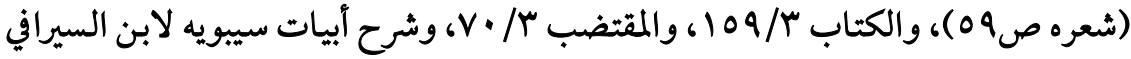

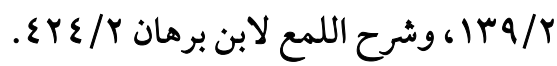

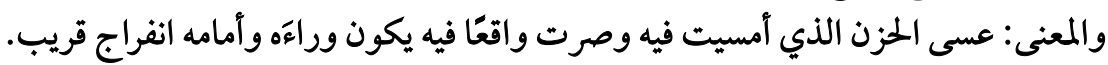
والشاهد فيه: حذف (أن) من (يكون)، ورفع الفعل.

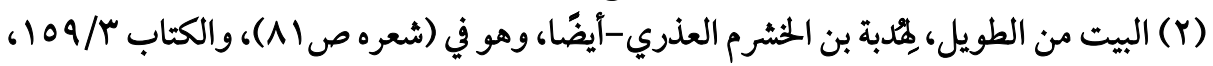

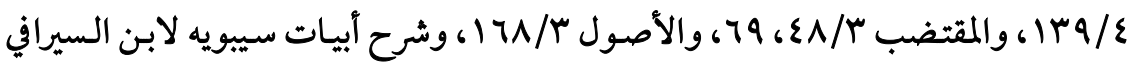
$.1 \mathrm{r} / \mathrm{r}$ والمُنهمِر : المُنصبّ، والجُون : الأبيض والأسود، وهو من الأضداد، والرَّباب: سحاب دون سحاب، والسَّكوب: كثير الصبّ. والشاهد فيه: حذف (أنْ) من (يُغني)، والبّ ورفع الفعل.

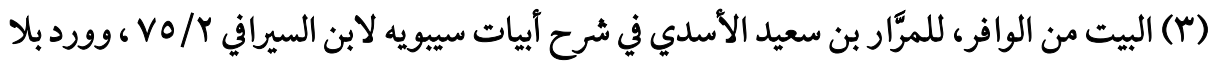

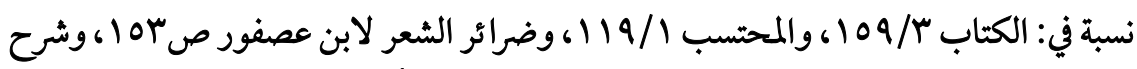

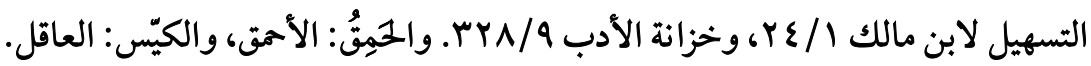

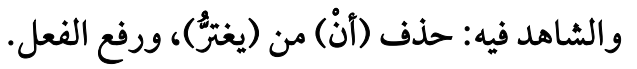




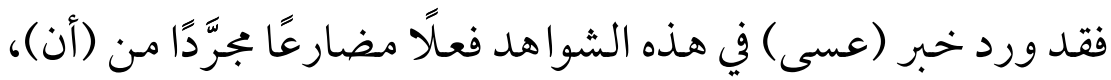

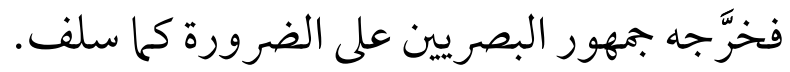

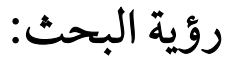

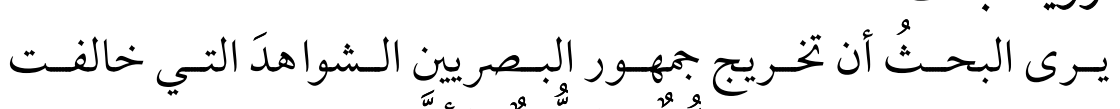

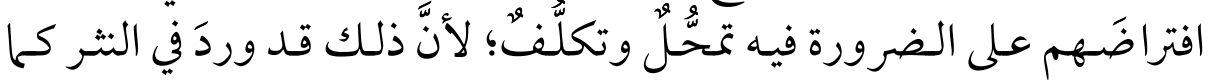

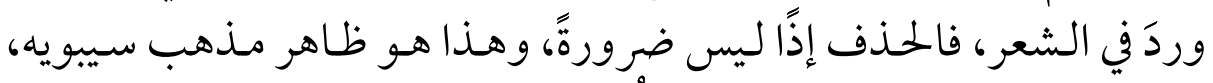

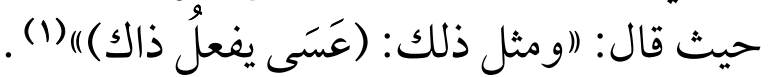

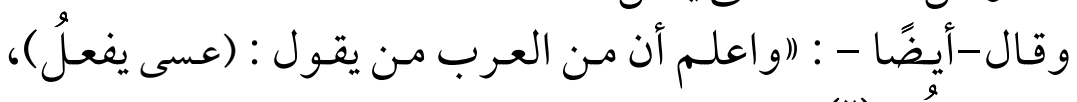

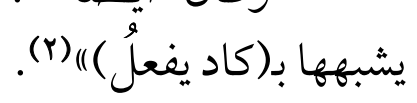
وذكر أبو حيَّان(r) أن حذفَ (أَنْ) من خبر (عَسَى) جائزٌّ في الكلام هو

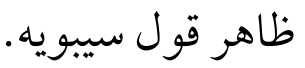
وتبع المبردُ سيبويه على ذلك، فقال: "(وييوز طرح (أنْ)، وليس بالوجه الجيد)( (ع)

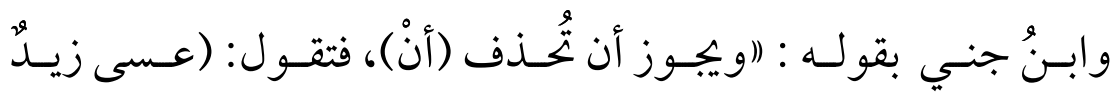
يقومُ)(1) (0)

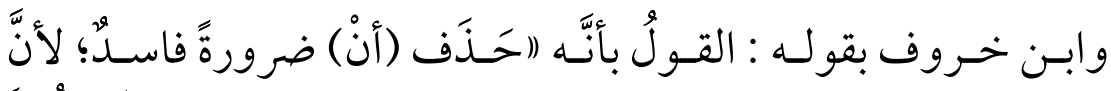

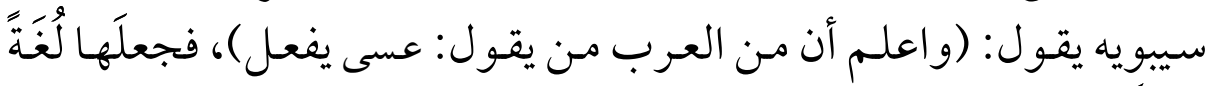
قليلةً، لا ضرورةًا)( (7).

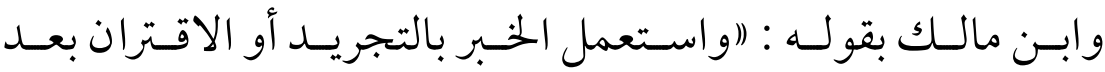


وأبو حيان بقوله : (او لا يُخَصُّ حذف (أنْ) من المضارع بالشعر؛ خلافًا

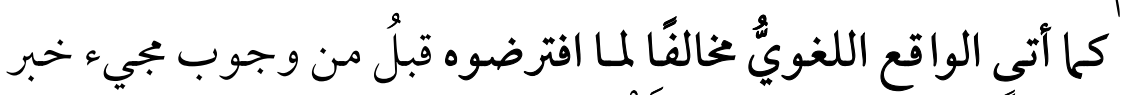

$$
\text { لزاعم ذلك)"(r). }
$$

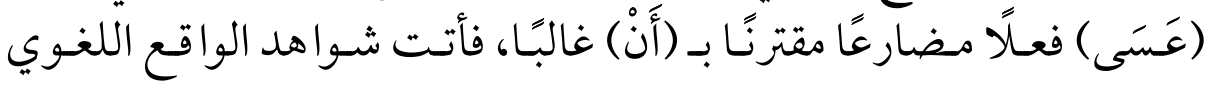

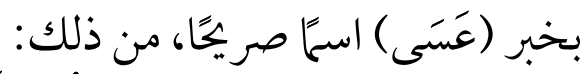

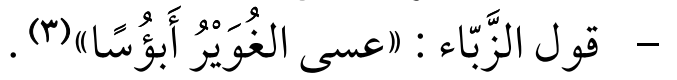

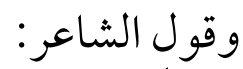

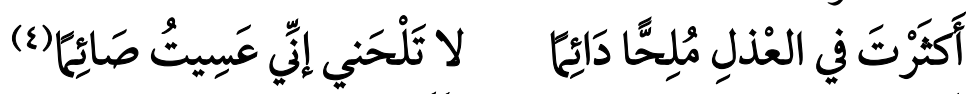

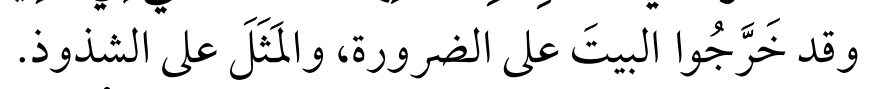

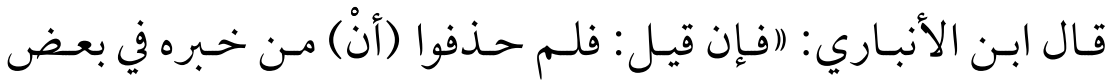

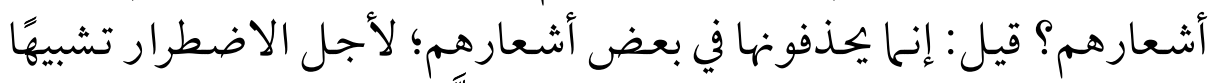

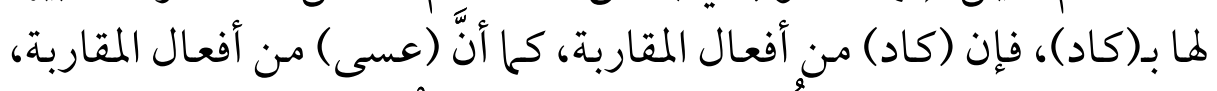

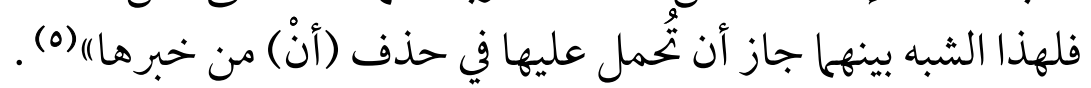

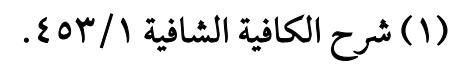

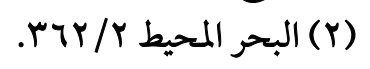

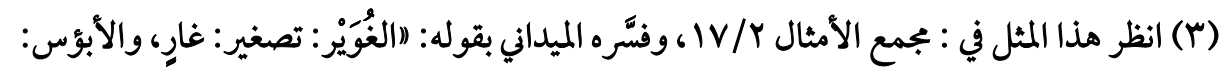

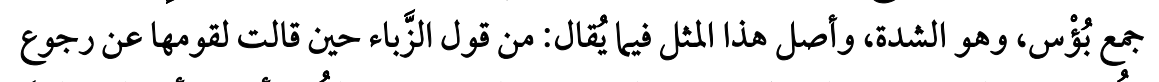

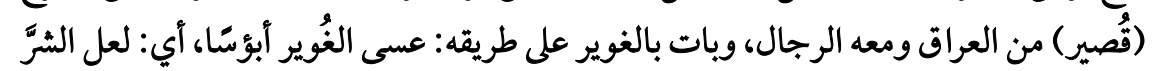

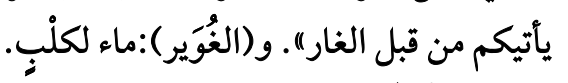

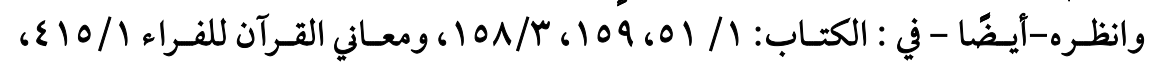

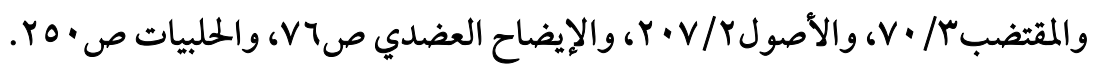

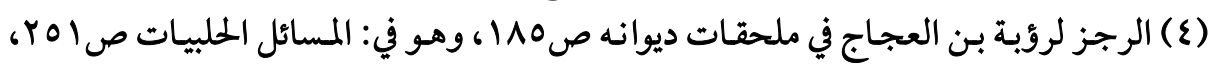

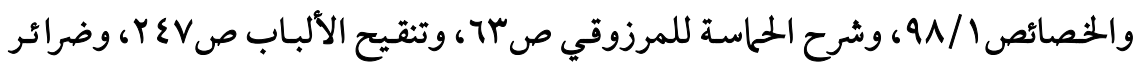

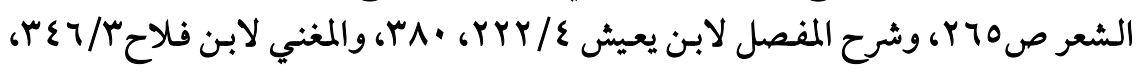

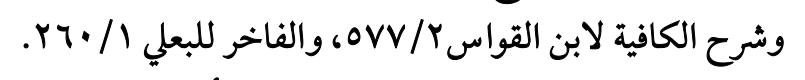
والمعنى : يعتذر الشاعر من يلح عليه بالطعام بأنه صائمّ.

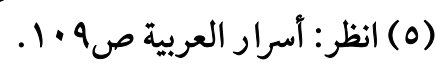




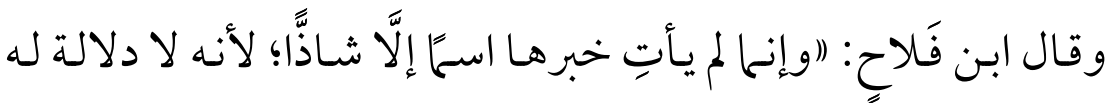

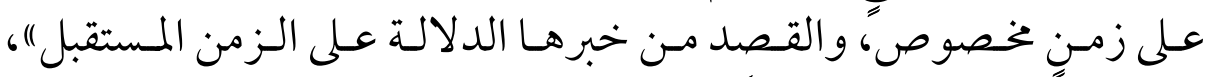

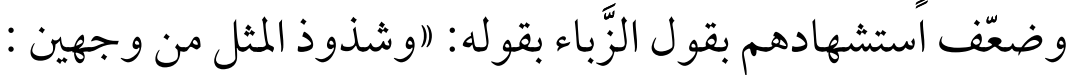

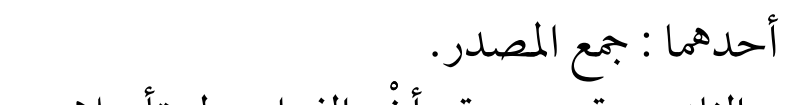

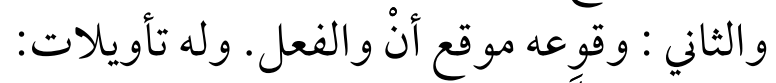

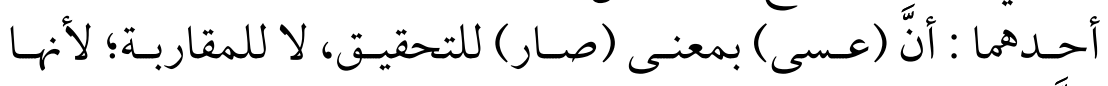

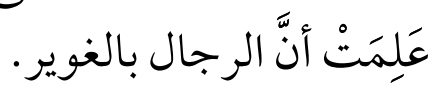

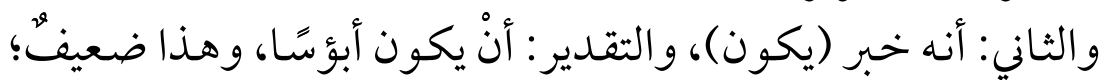

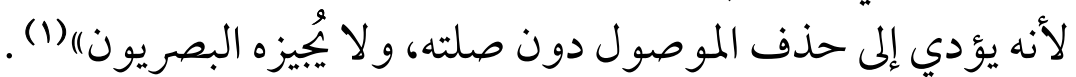

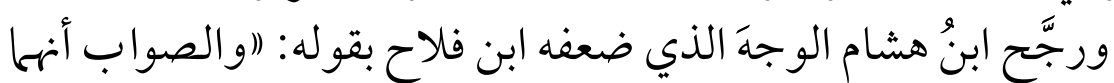

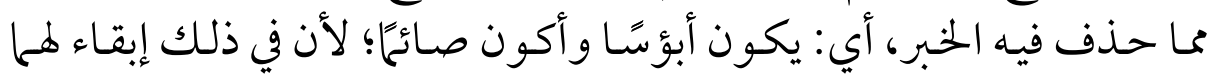

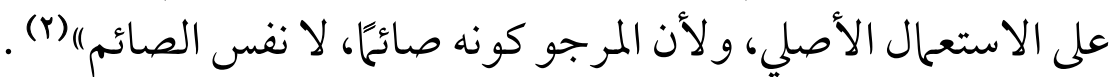

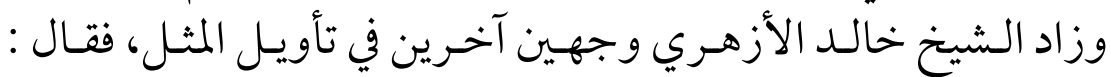

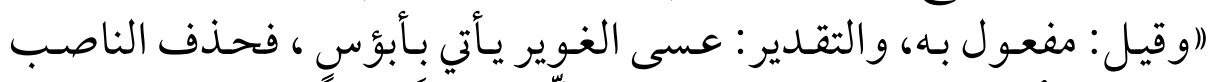

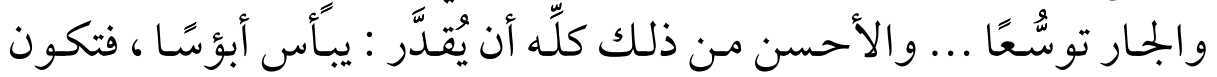
مفعو لا مطلقًا)(r)

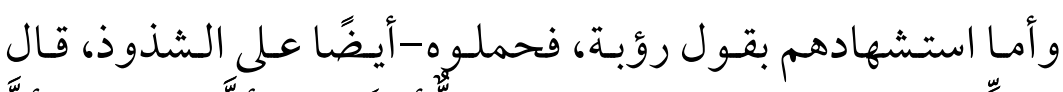

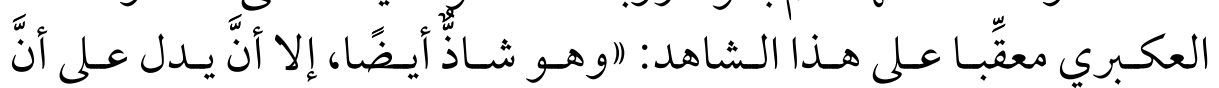

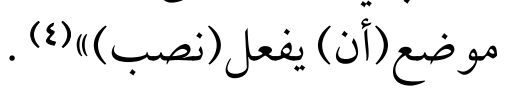

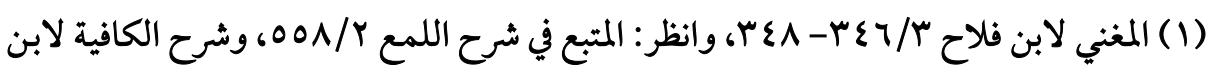

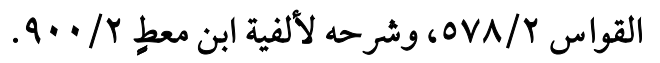

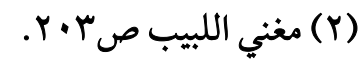

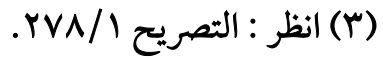

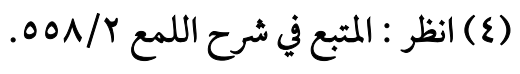




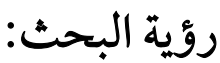

يرى البحث أنه كان يجدر بالنحويين إجازة هذه الأشكال البنيوية التي

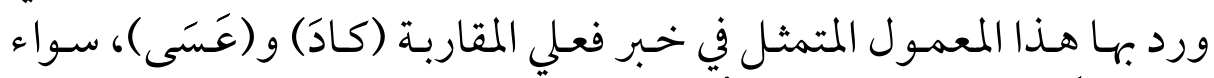

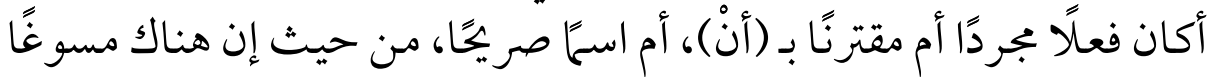

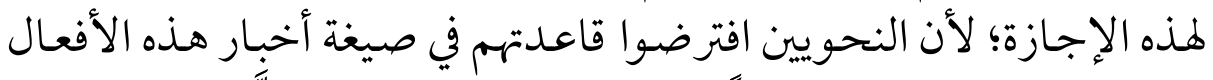

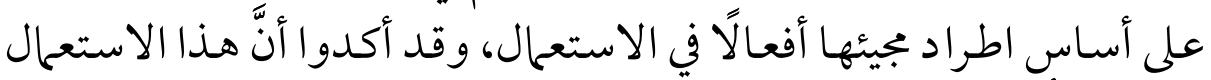

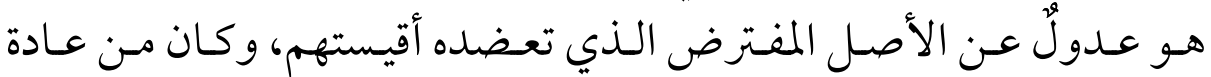

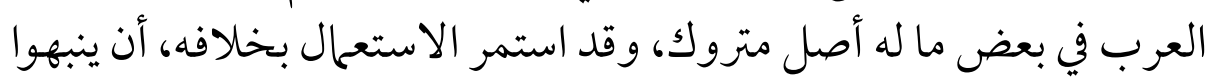
على ذلك الأصل لئلا يجهل.

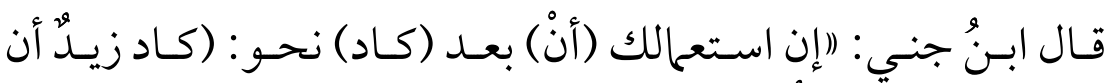

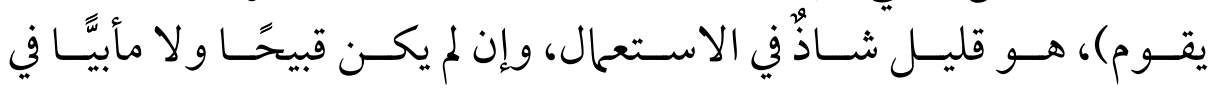
(القياس"(1)

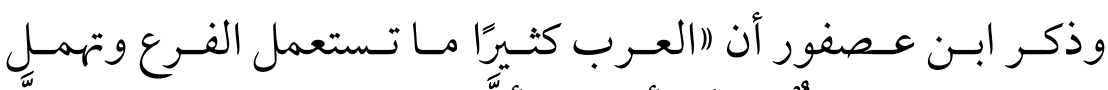

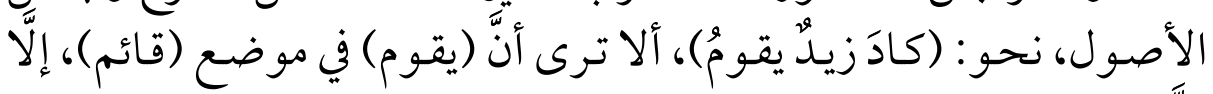

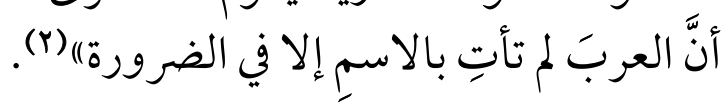

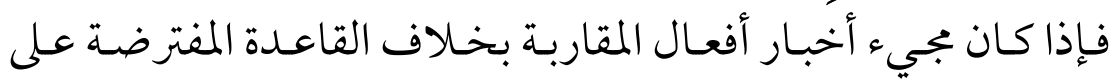

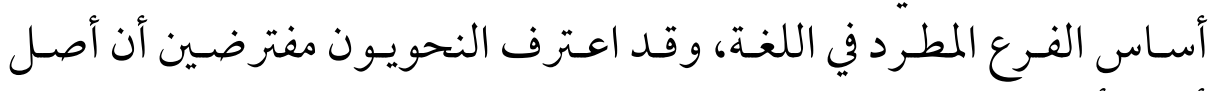

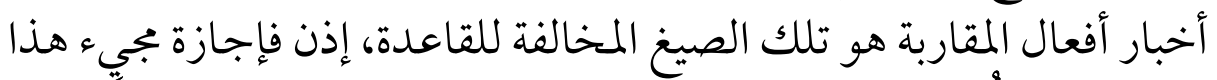

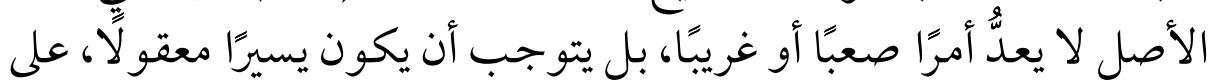

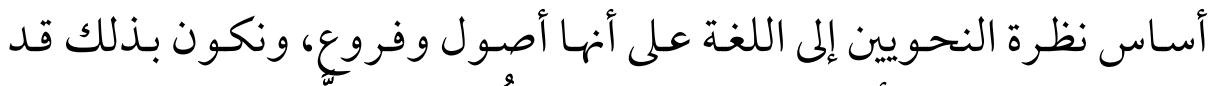

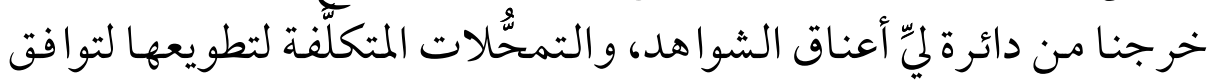
القاعدة التي افترضوها.

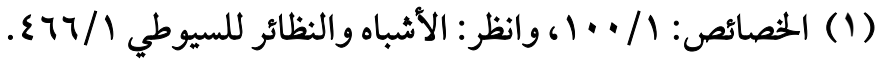

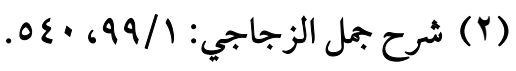




\section{بنيـة الفاوهـل

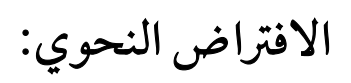

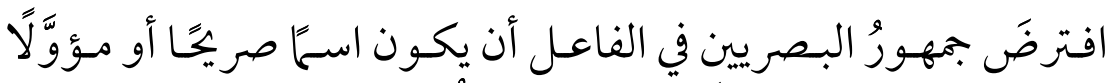

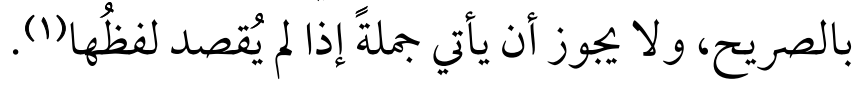

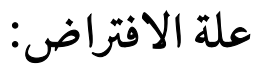

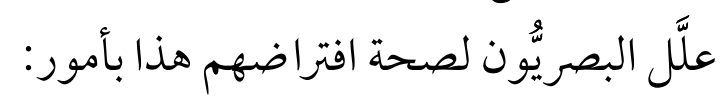

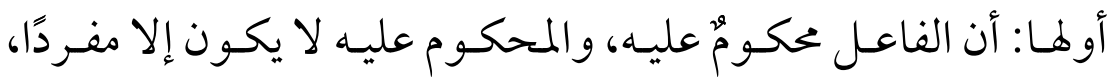

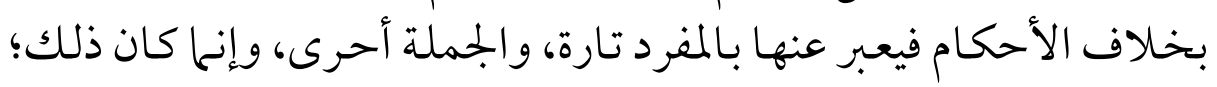

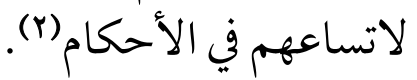

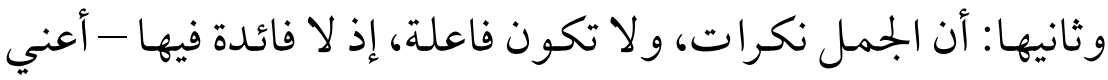

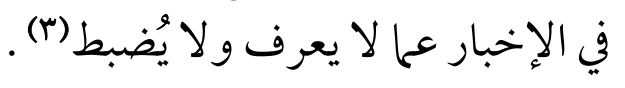

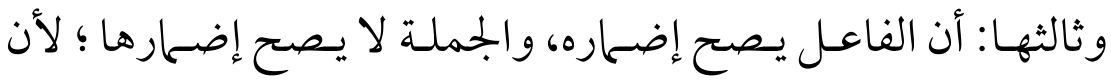

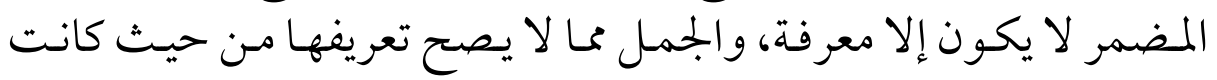

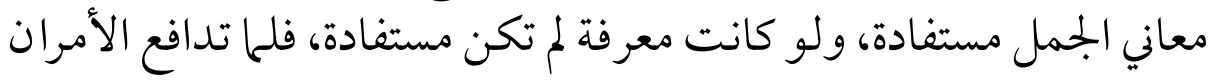

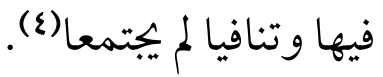

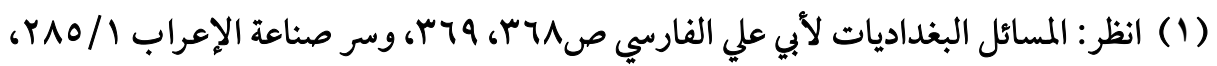

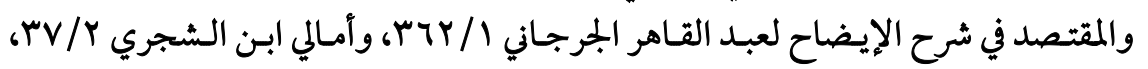

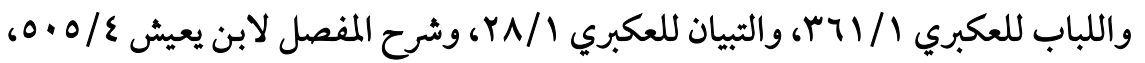

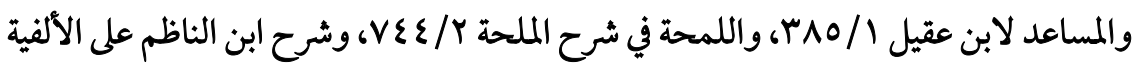

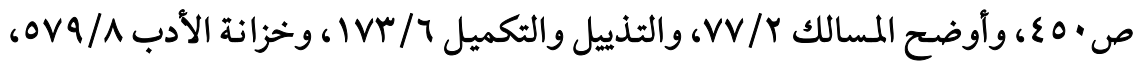

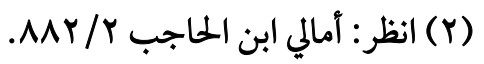

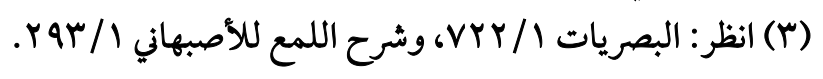

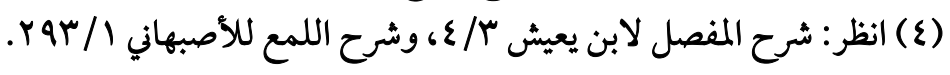




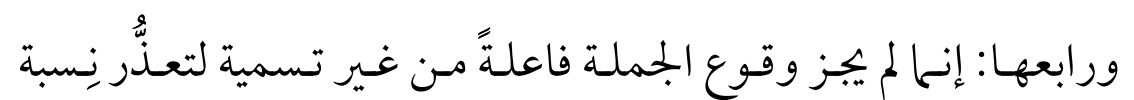

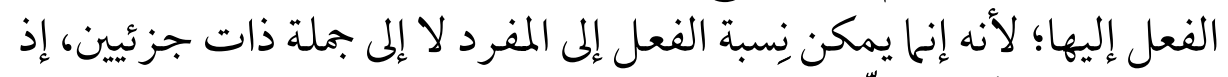

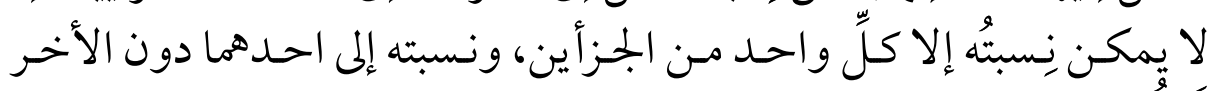

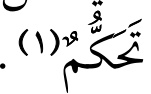

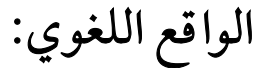

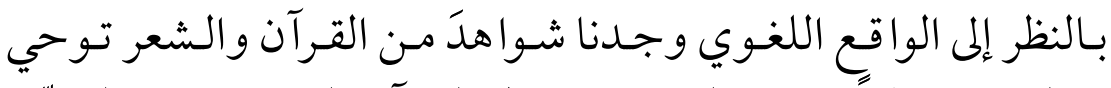

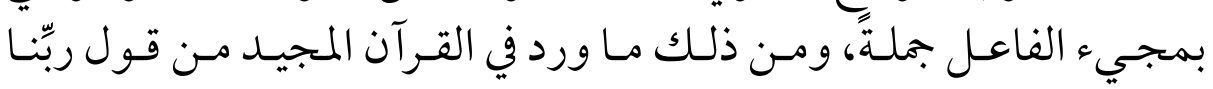

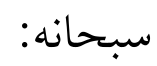

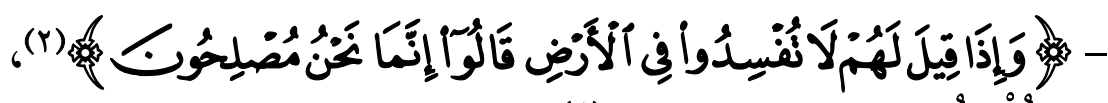

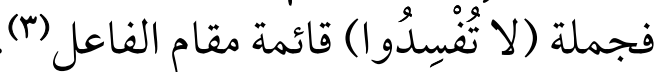

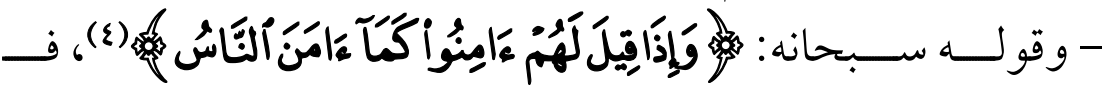

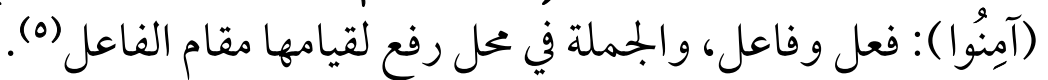

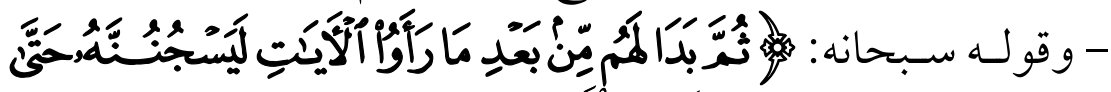

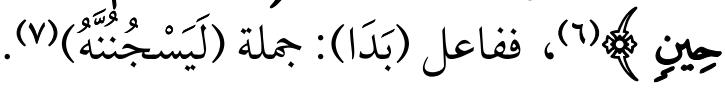

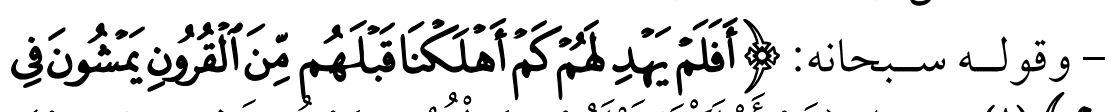

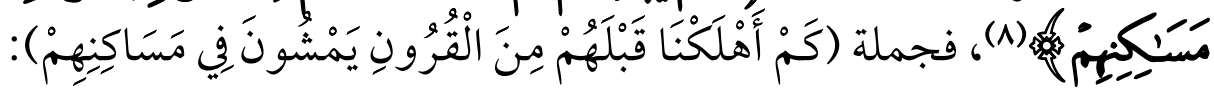

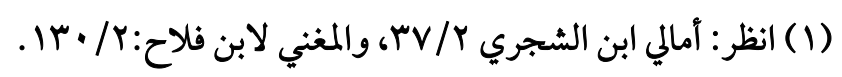

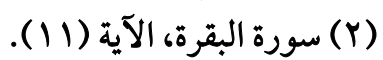

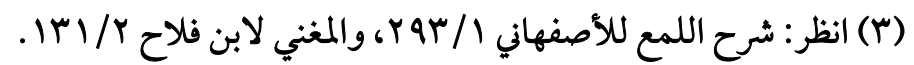

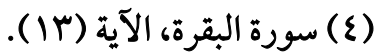

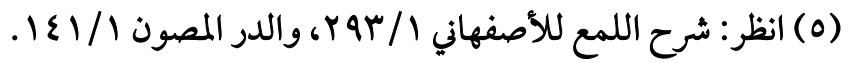

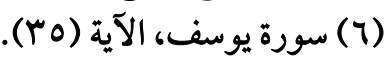

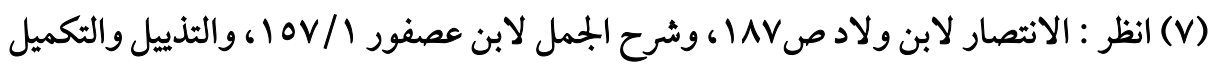

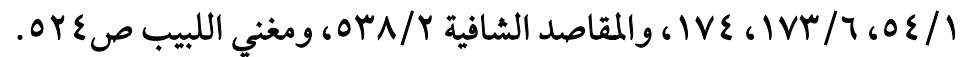

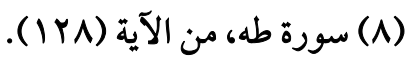


فاعل لـ (يَهْدِ) (1)، فإن اعترض بأنَّ (كَمْ) هُهنا استفهامية، فلا يعمل فيها ما

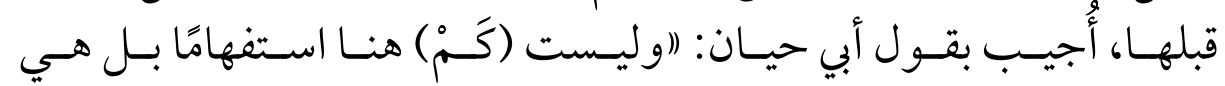

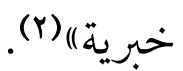

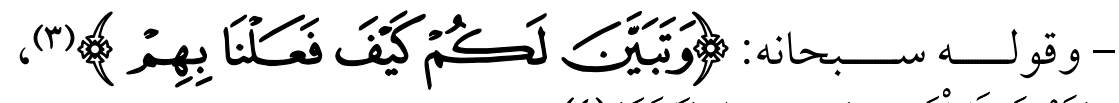

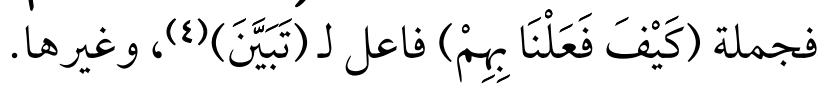
- ومن الشعر: قول الشاعر:

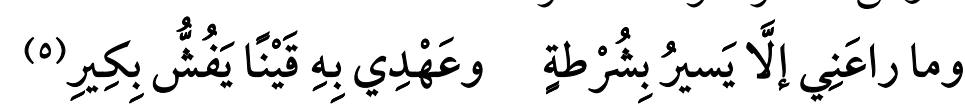

$$
\text { وقجملة: (يسير) فاعل لـ (راعني). }
$$

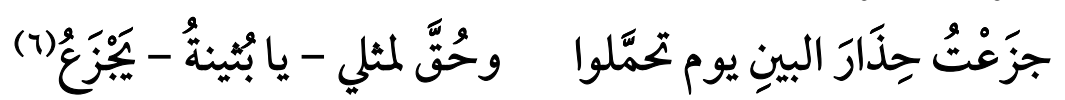

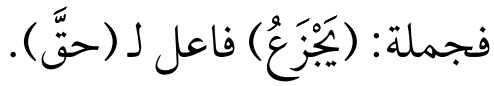

$$
\begin{aligned}
& \text { وقول الآخر: }
\end{aligned}
$$

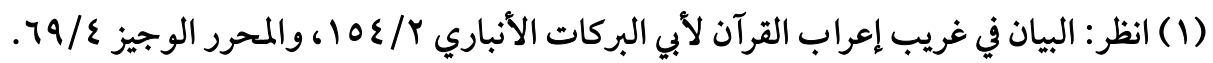

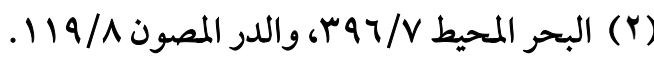

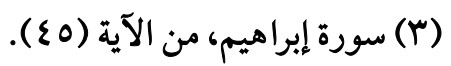

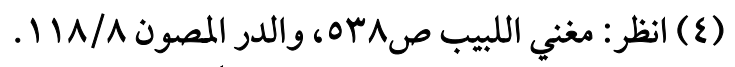

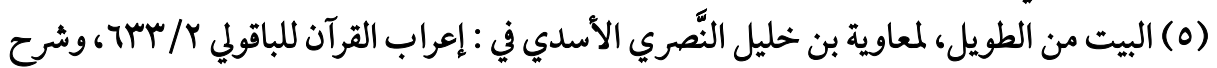

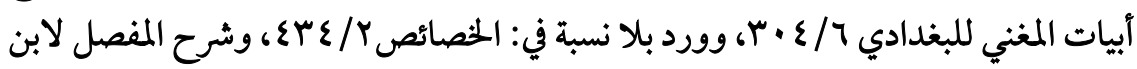

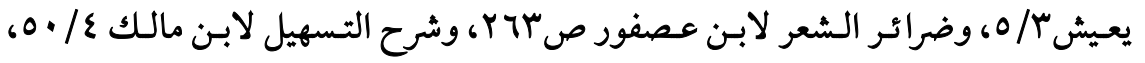

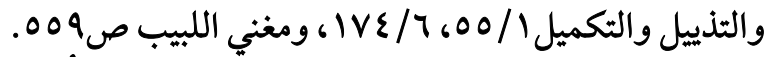

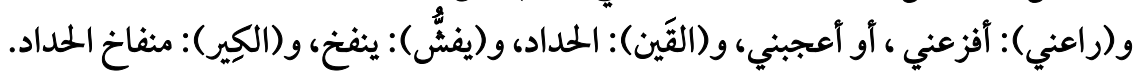

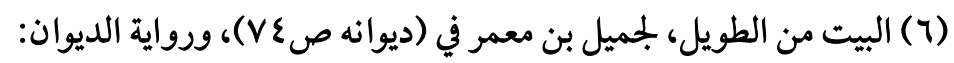

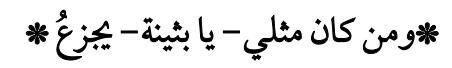

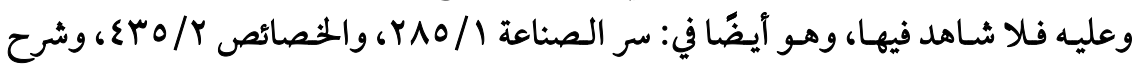

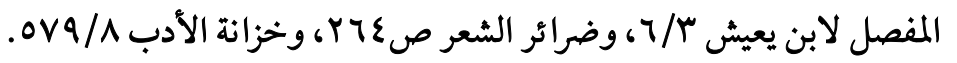




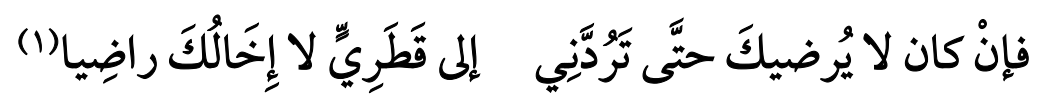

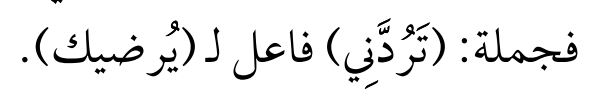

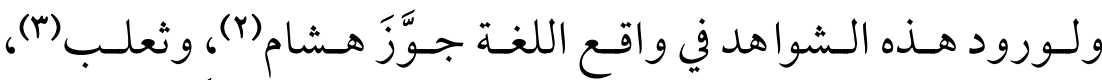

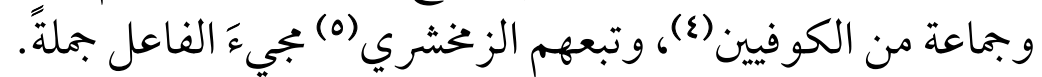

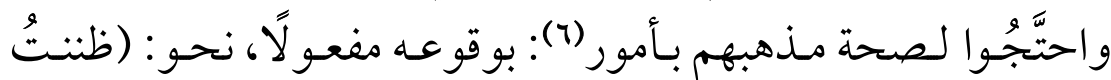

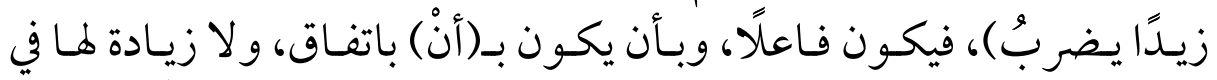

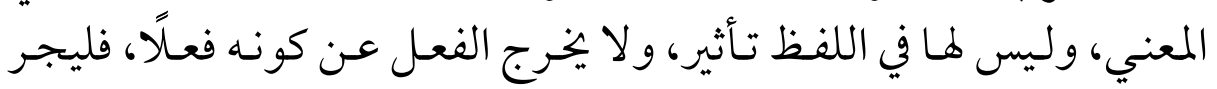

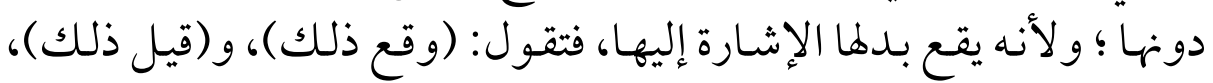

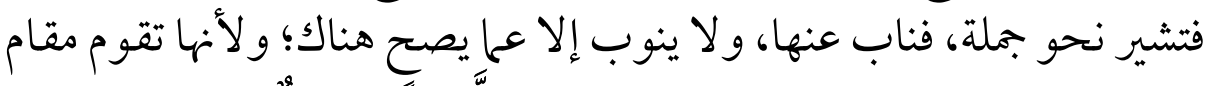

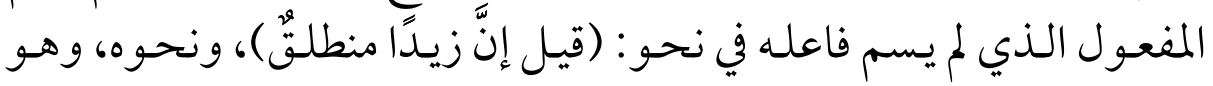

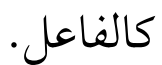

\section{صنيع البصريين مع هذه الشواهد:}

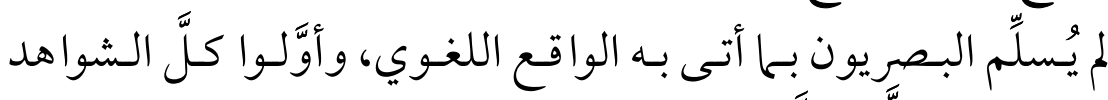

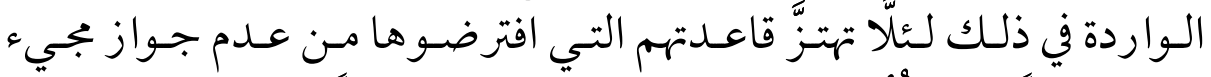

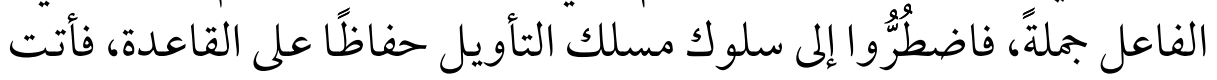
تأويلاتهم كالآتي:

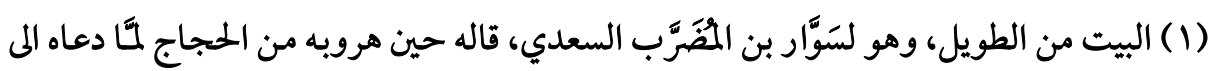

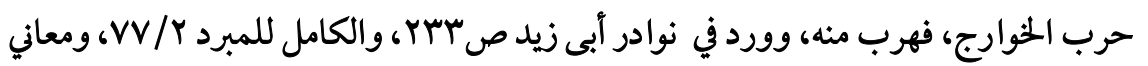

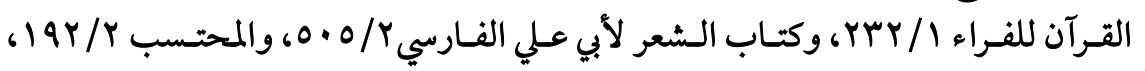

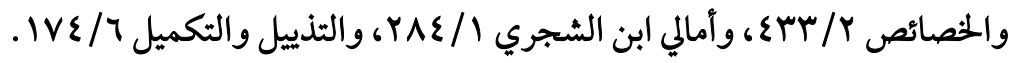

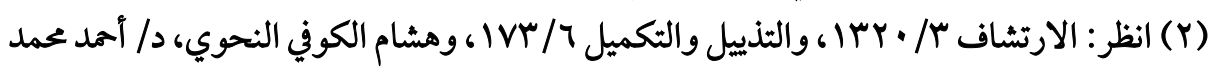

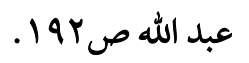

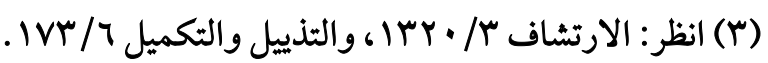

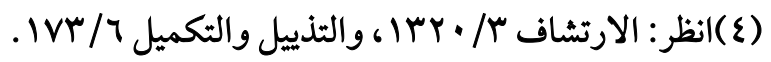

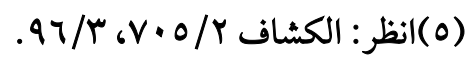

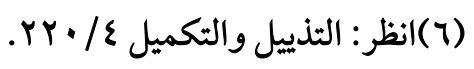




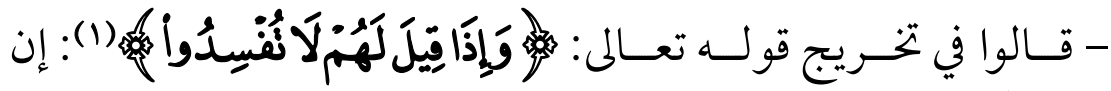

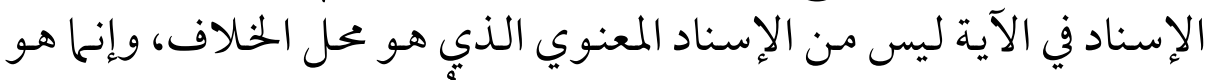

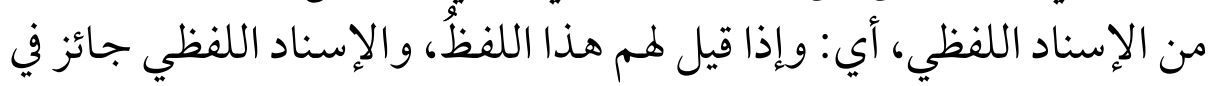

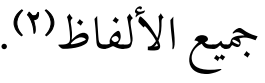

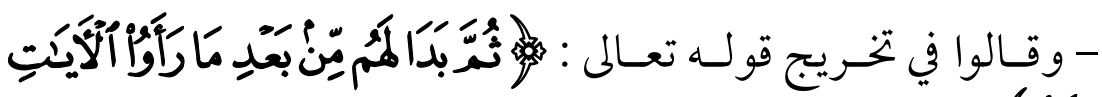

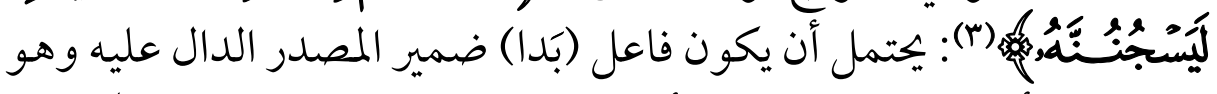

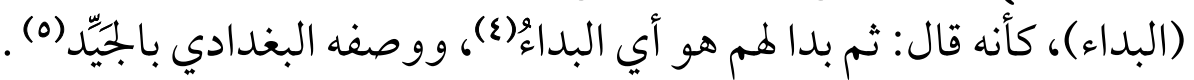

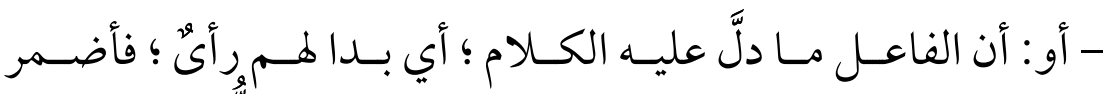

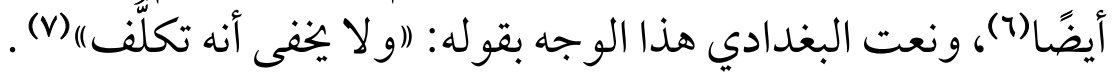

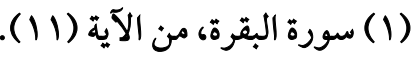

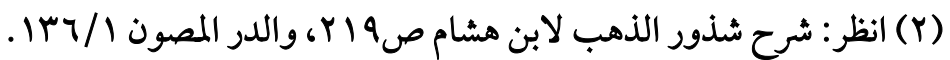

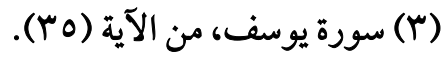

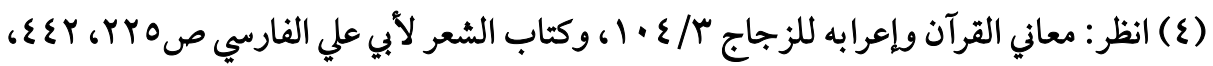

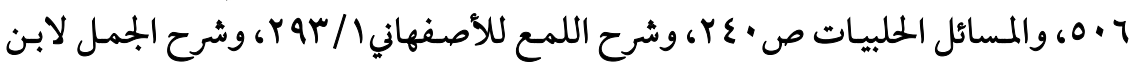

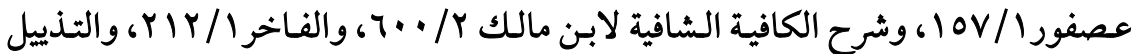

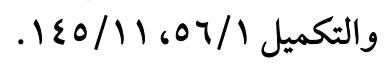

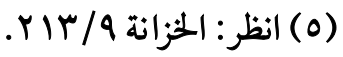

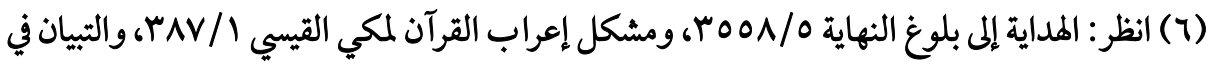

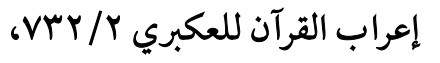

(V) المزانة 


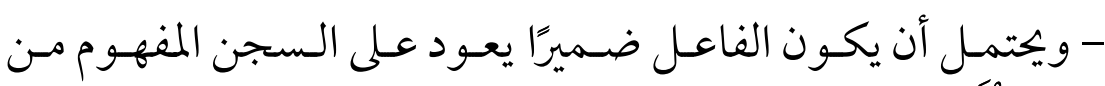

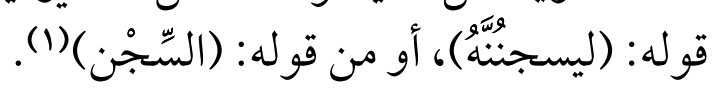

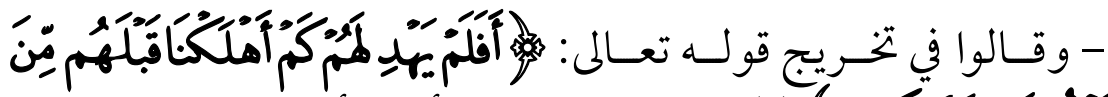

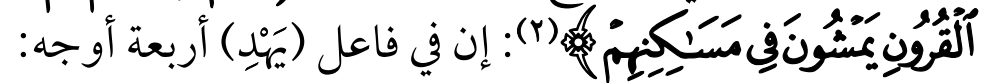

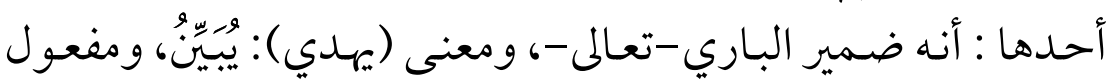

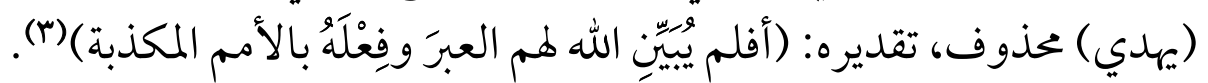

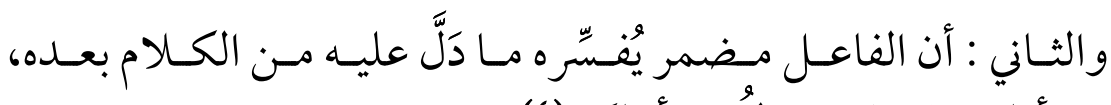

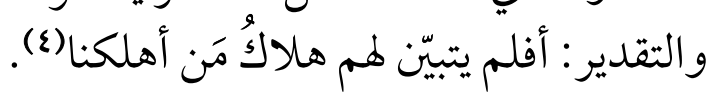

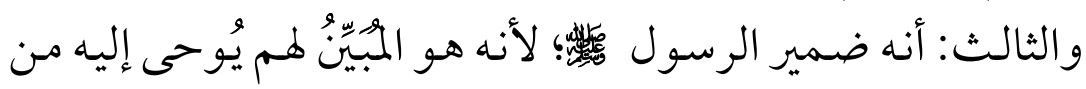

$$
\text { أخبار الأمم السالفة، والقرون أنهير المساضية (0) }
$$

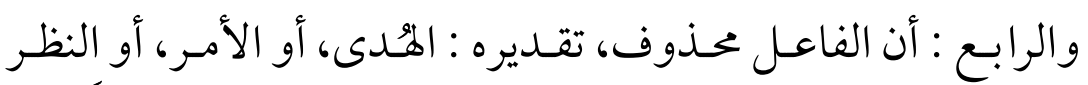

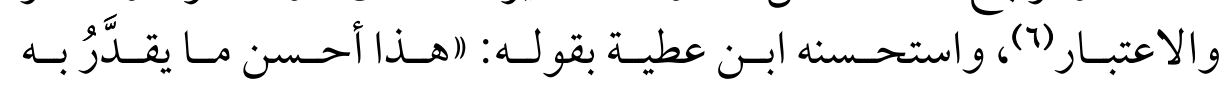
عندي") واعنبار)

وأردف أبو حيان هذا الاستحسان بقوله: (اوقال ابن عطية: وهذا

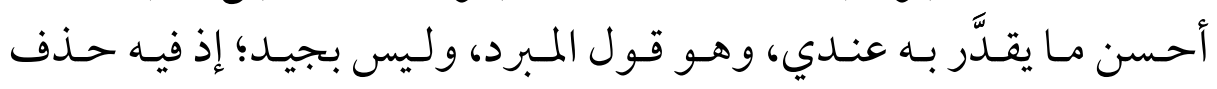

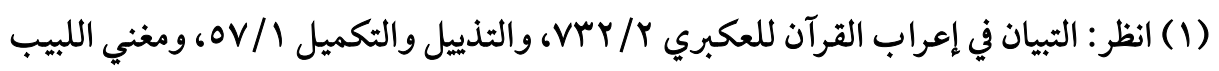

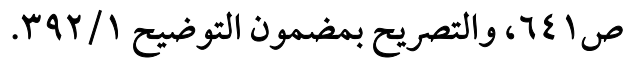

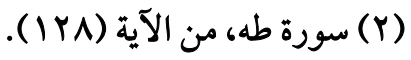

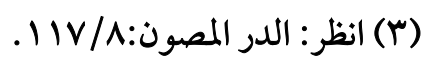

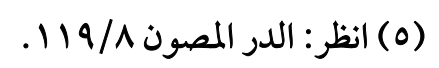

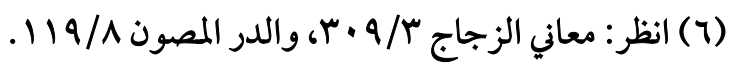

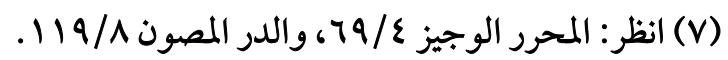




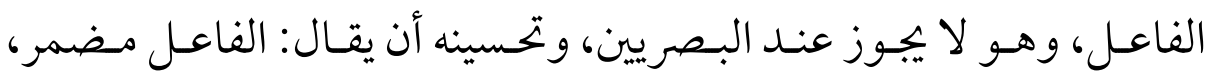

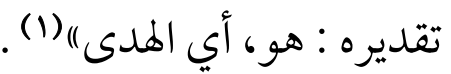

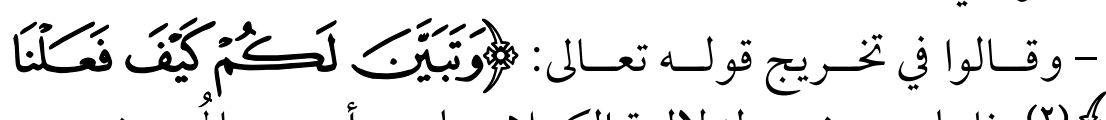

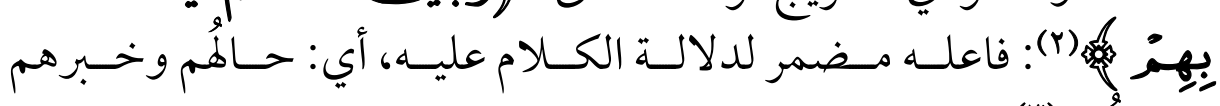

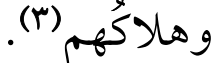

وأما الشعر فتأوَّلوه على إضمار (أَنْ) في البيتين الأولين، قال ابن يعيش:

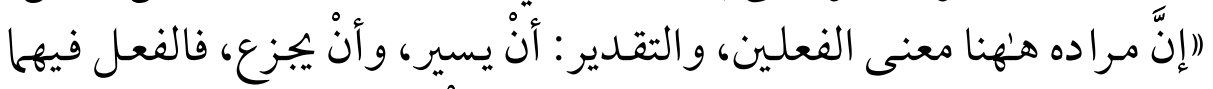

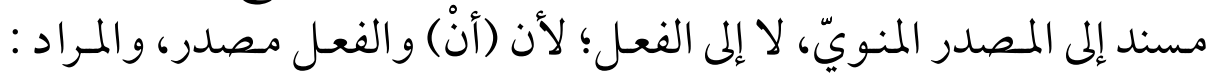

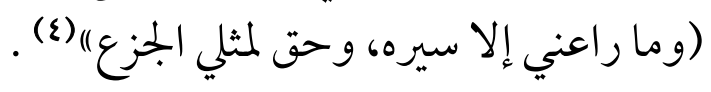

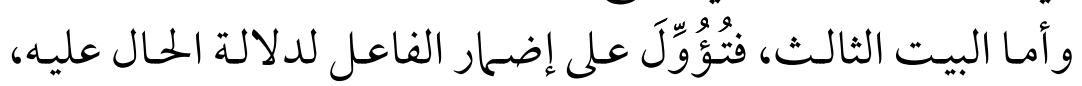

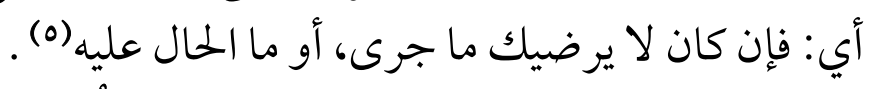

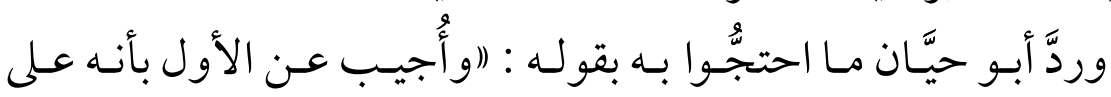

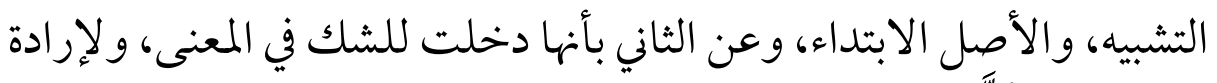

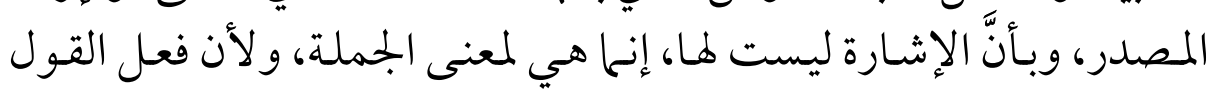

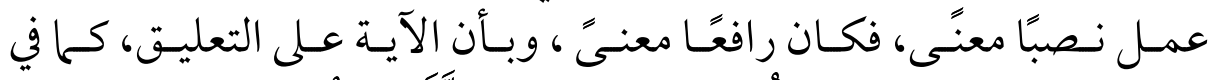

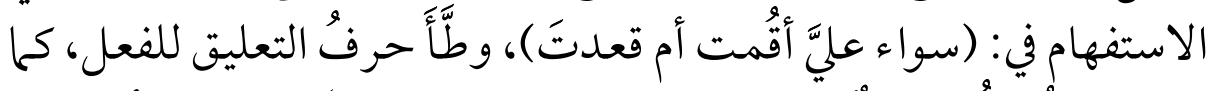

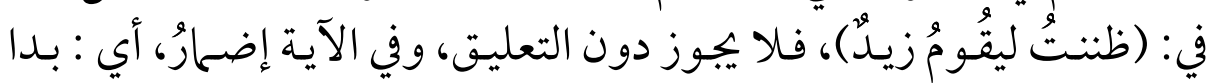

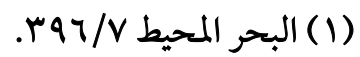

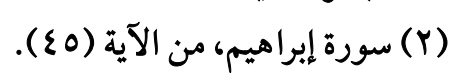

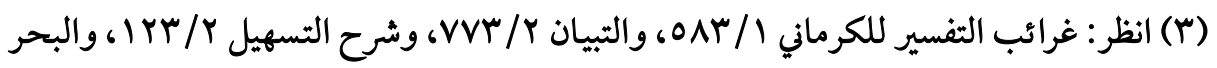

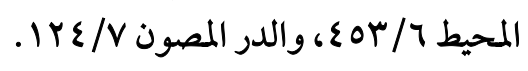

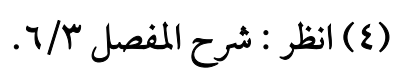

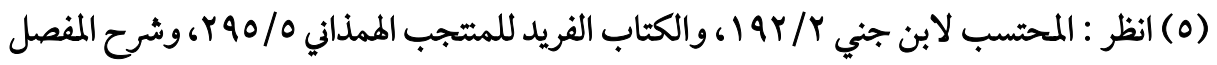

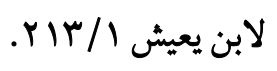


هم الأمر، أو بَدْوُ، فأُضمر لدلالة الفعل عليه. وكذلك: قيل لهم قولُهوهو هذا

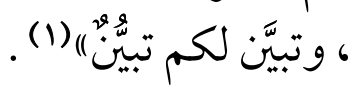

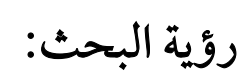

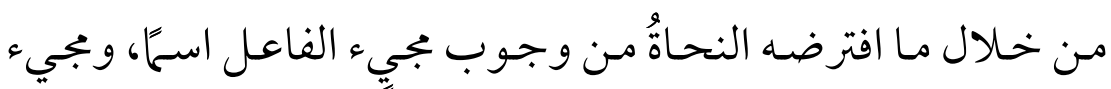

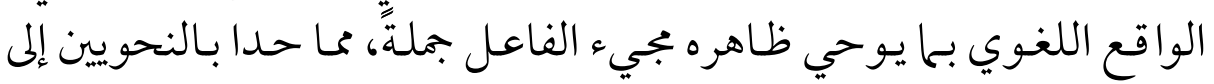

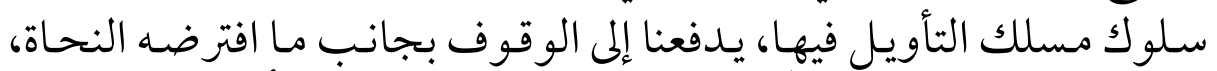

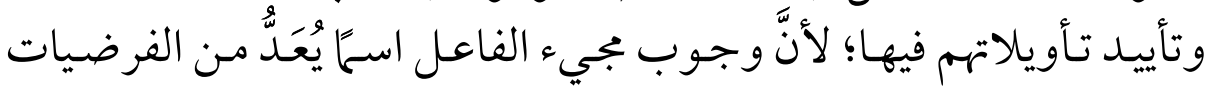

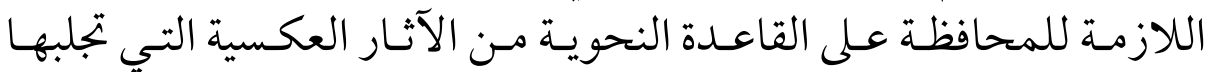

الإجازة.

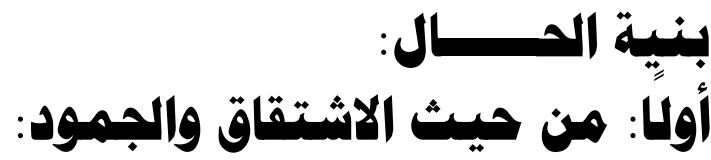

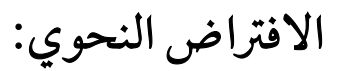

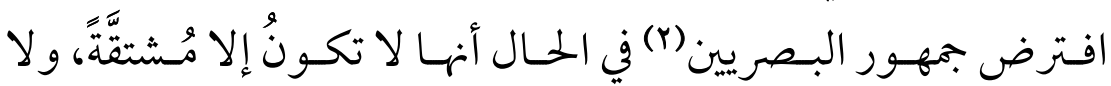

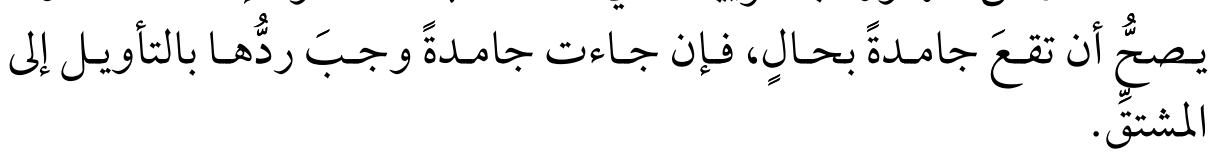
علَّة الافتراض: ع ع ع

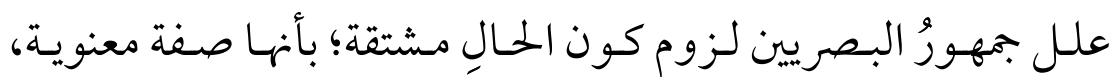
وحقيقة الصفة أن تكون في المشتق (r).

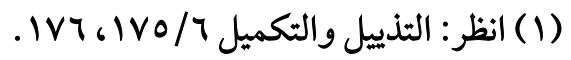

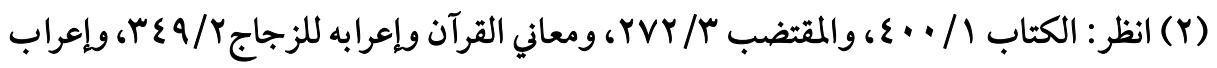

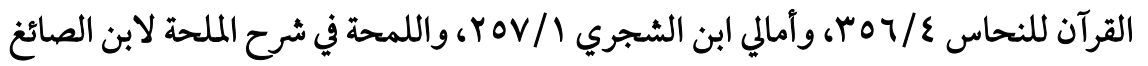
rrVA/1

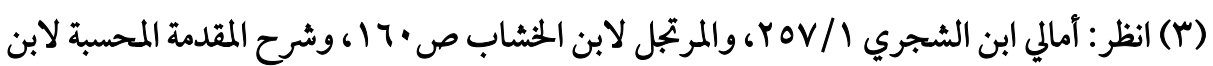

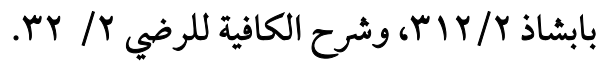




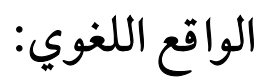

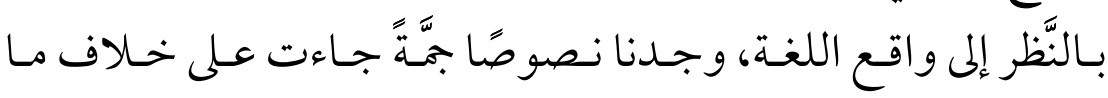
افترضه جمهور البصريين، منها:

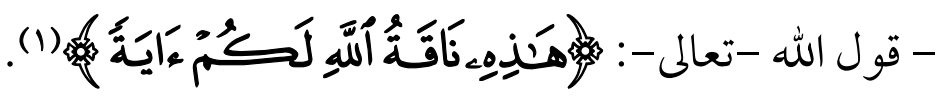

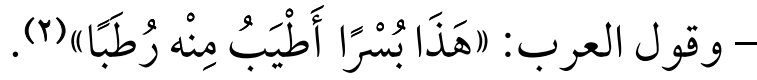

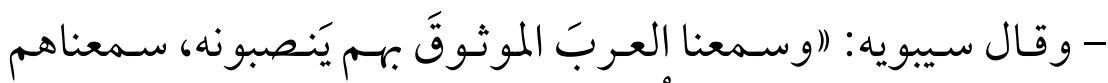

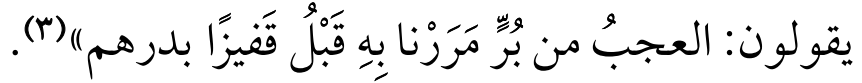

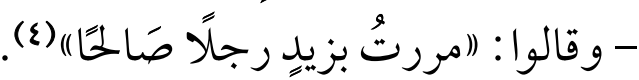

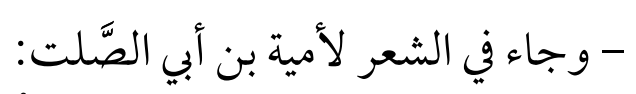

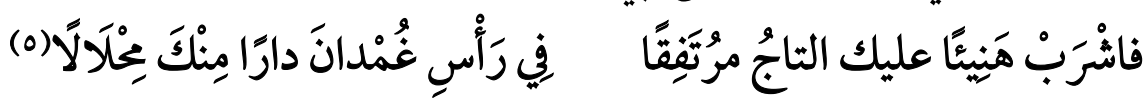

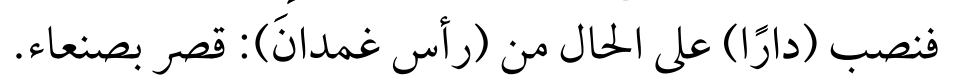

$$
\text { (1) سورة الأعراف، من الآية (VY)، وسورة هود، من الآية (ع) (Y). }
$$

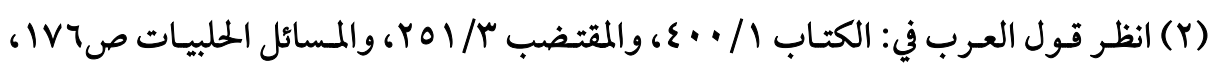

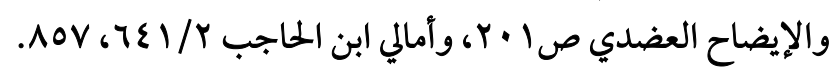

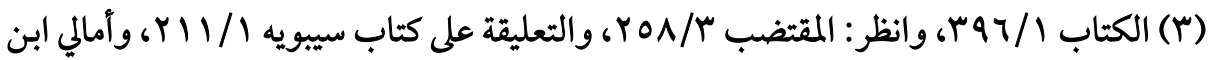

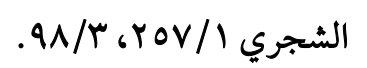

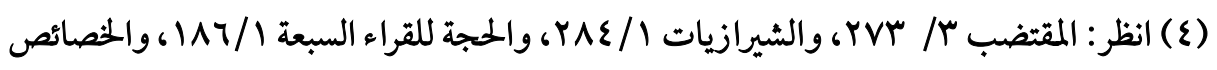

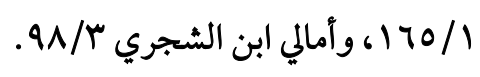

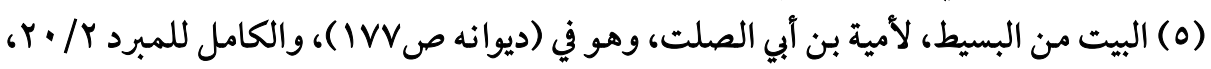

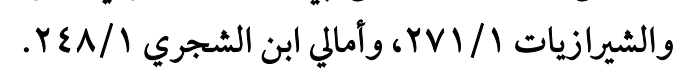

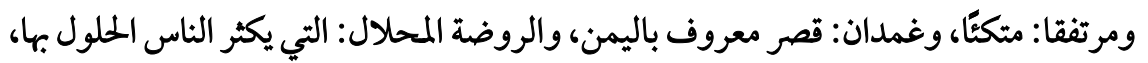

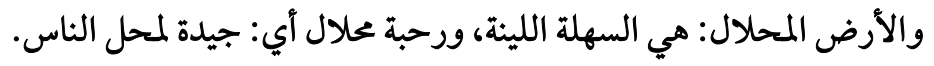

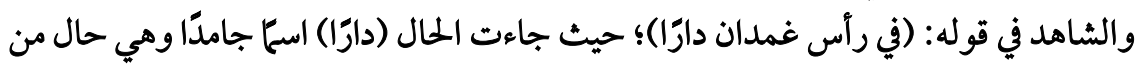

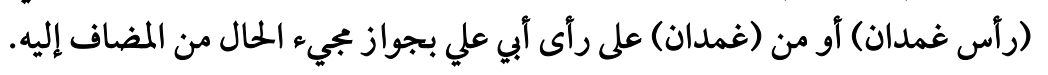


- و ومنه قول هند بنت عتبة بن ربيعة أم معاوية بن أبي سفيان:

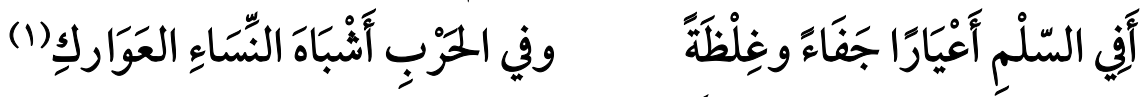

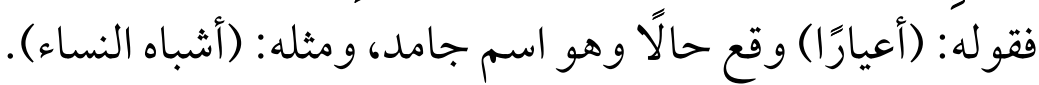
- مقول وجل من أصحاب علي بن أبي طالب - رضي الله عنه - : فمَا بالُنا أمسِِ أُنْدَ العرينِ

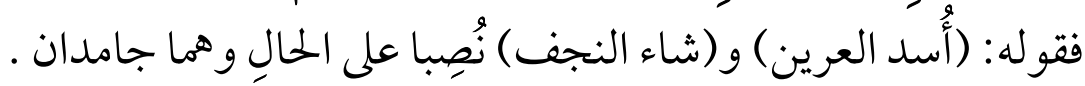
- وقول جرير من قصيدة يهجو الأخطل:

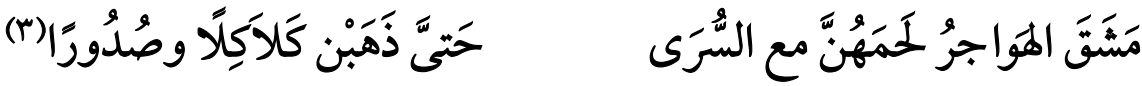

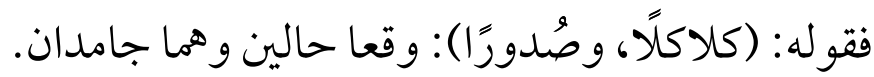
- مقول وقول عمرو بن عهَّار النهدي:

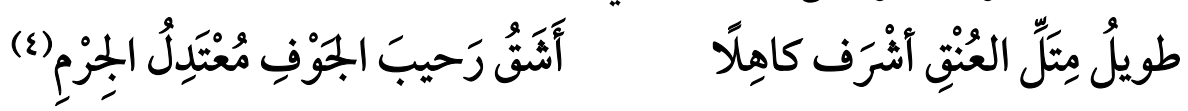

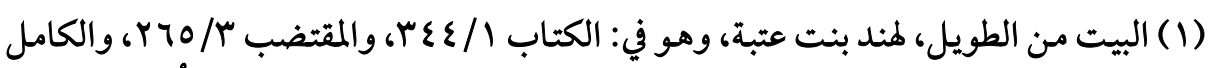

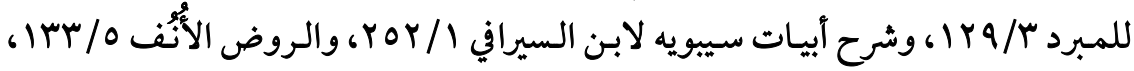

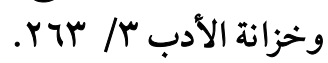

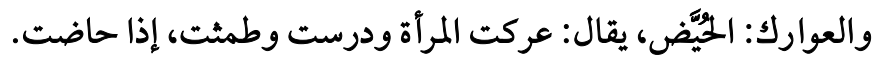

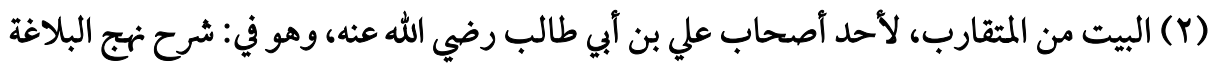

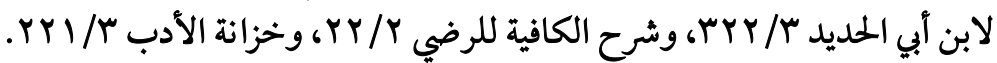

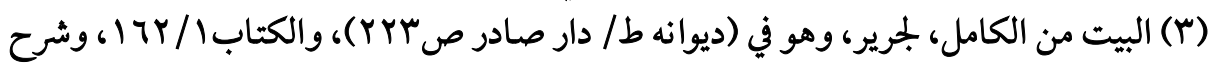

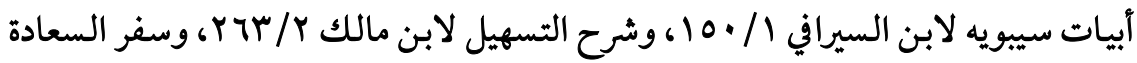

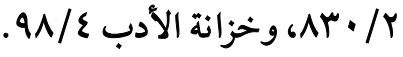

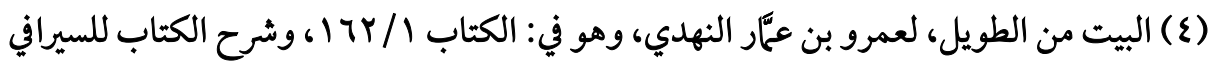

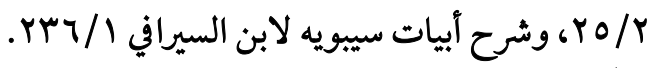

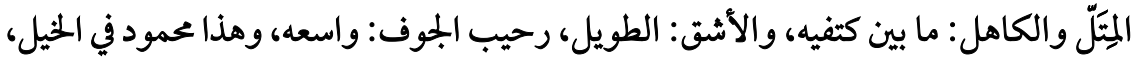

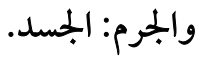
يريد: إنه كصورة مصورة في الحسن معتدل الخلق. 


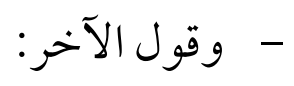

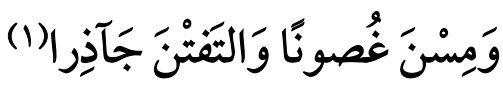

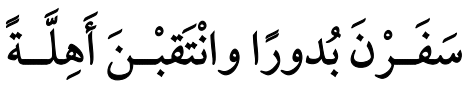

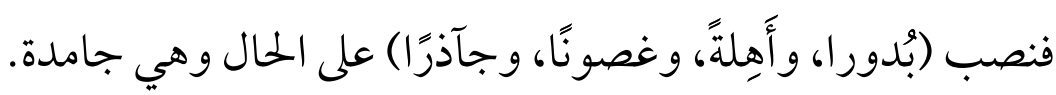

$$
\text { صنيع البصريين مع تلك الشواهد: }
$$

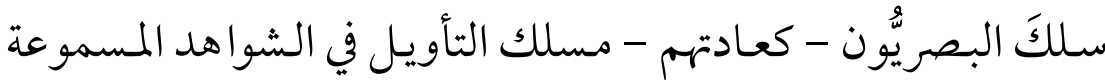

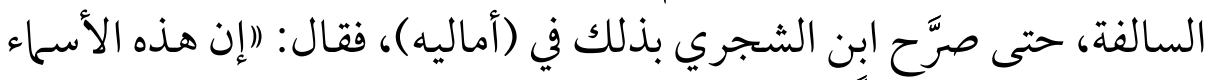

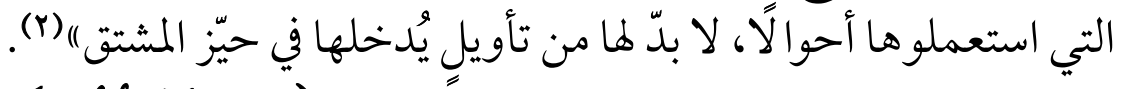

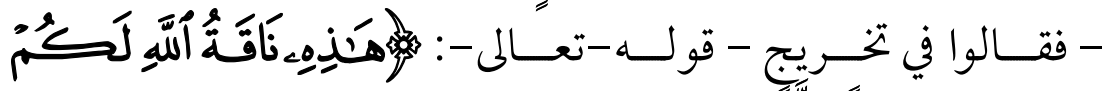

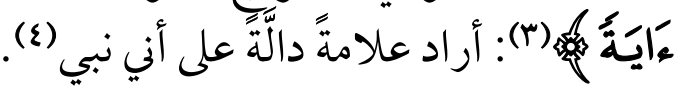

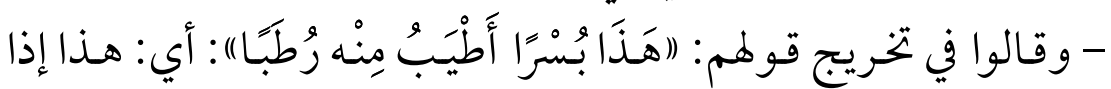

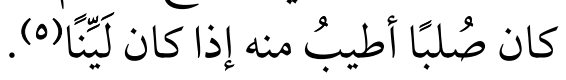

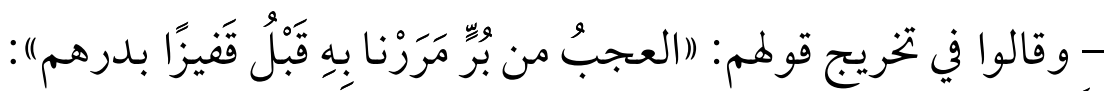

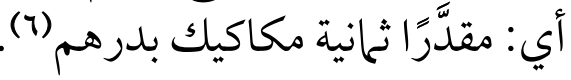

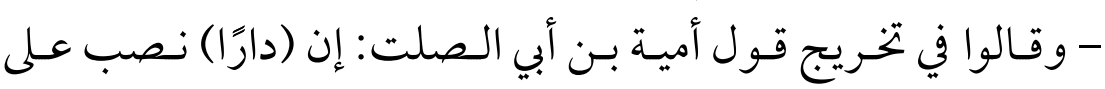

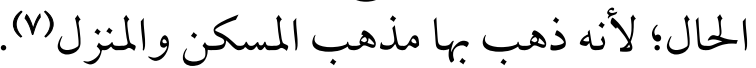

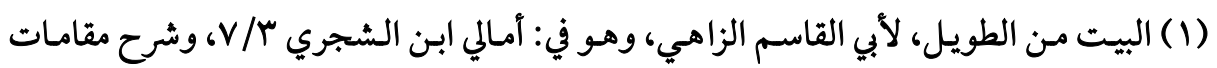

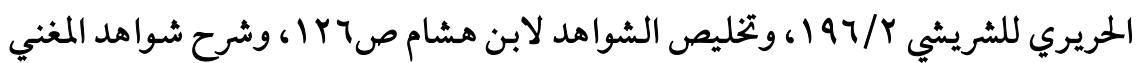

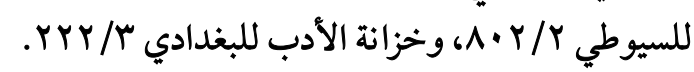

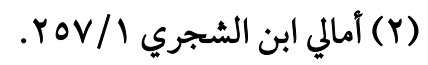

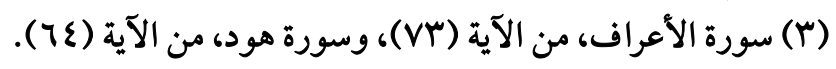

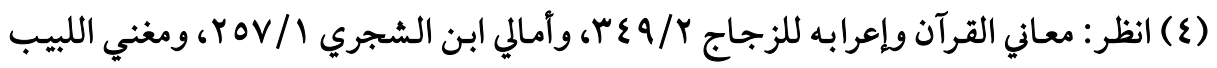
صPrV

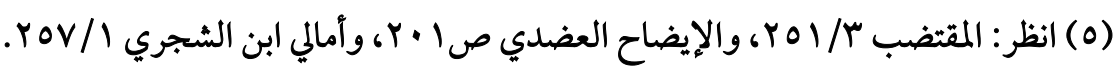

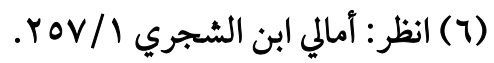

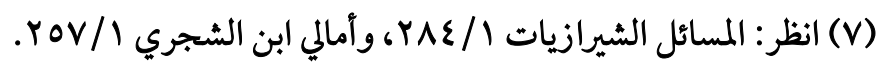


- وقالوا في تخريج قول هند بنـت عتبـة: إنَّ (أعْيَارًا) أقيم مقـام اسـم

$$
\text { مشتق يقدر بـ (بُلَلََاء)(1). }
$$

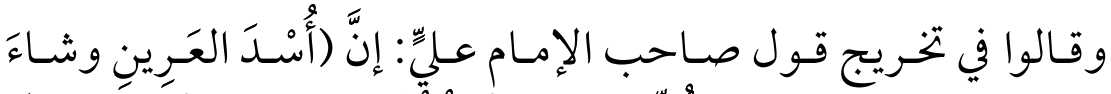

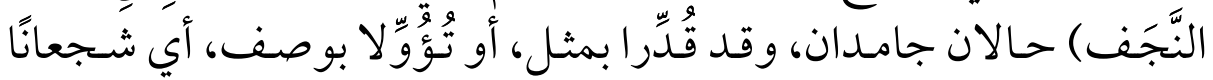

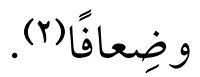

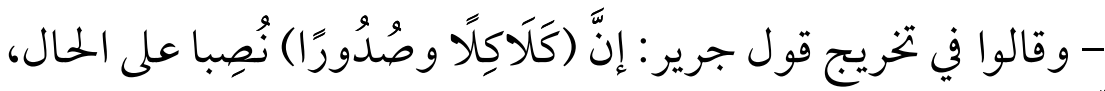

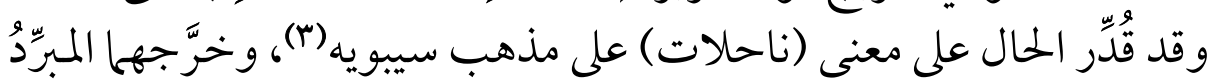

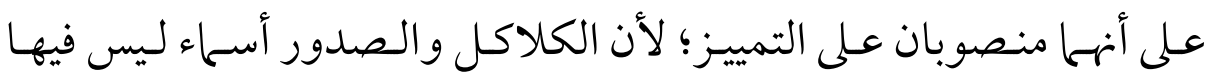

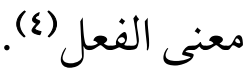

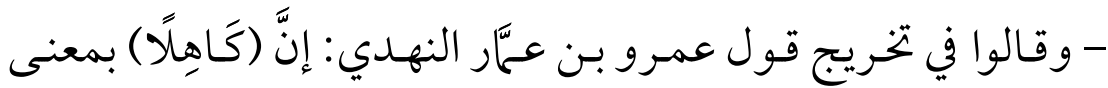

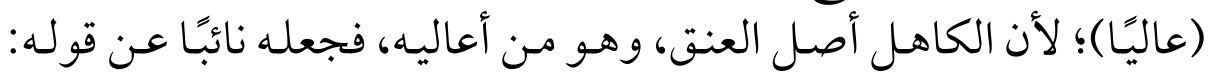

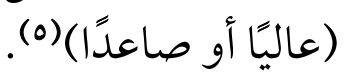

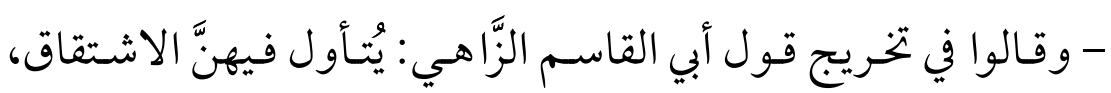

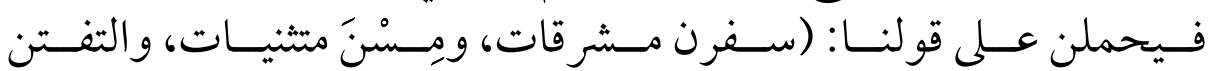

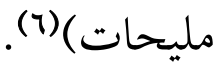

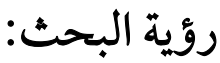

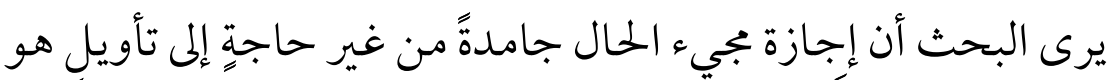

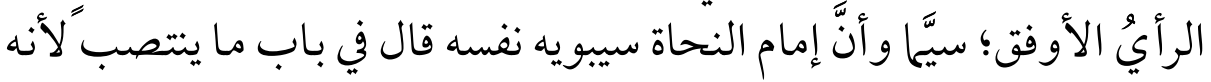

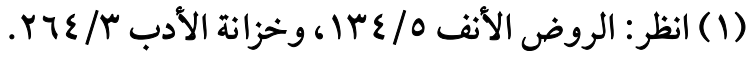

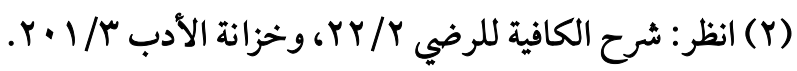

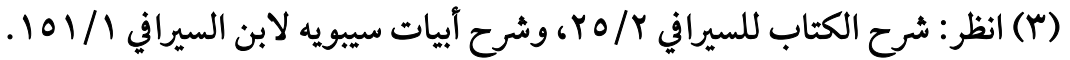

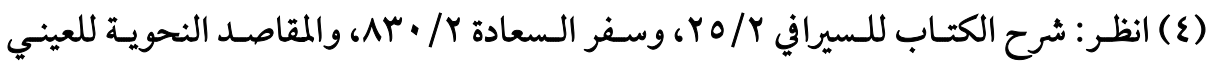

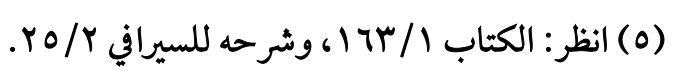

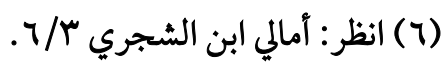




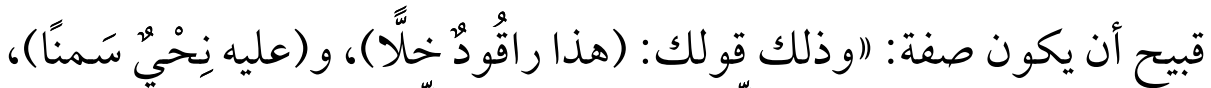

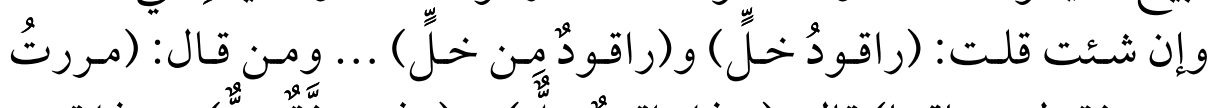

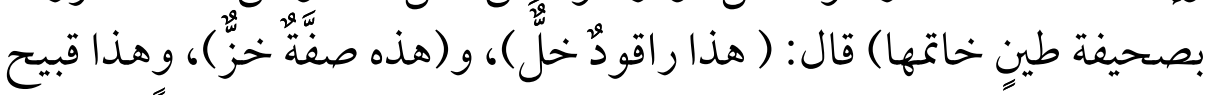

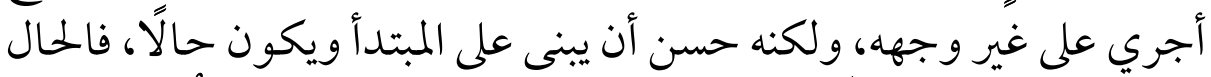

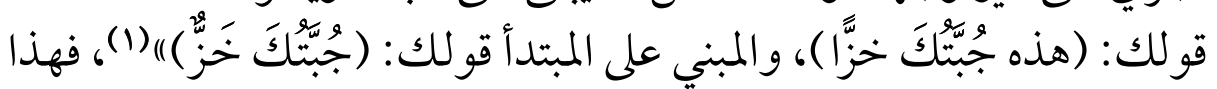

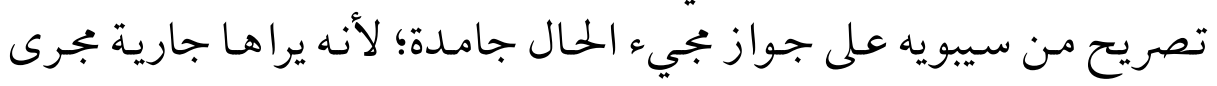
الخبر.

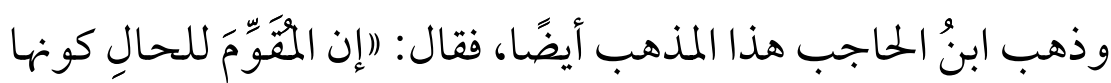

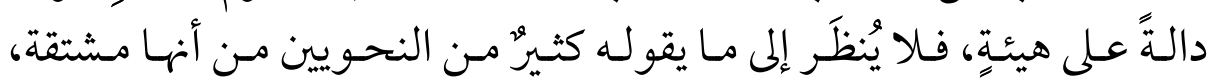

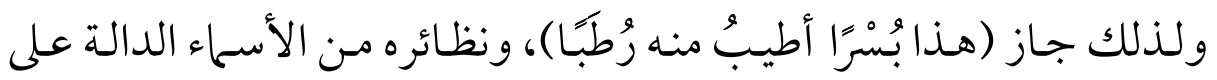
الهيئات)|(r)

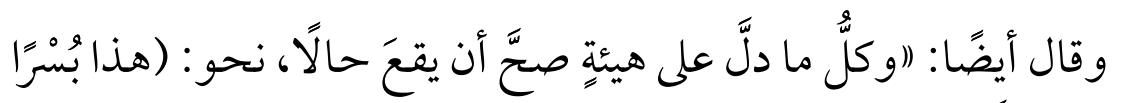

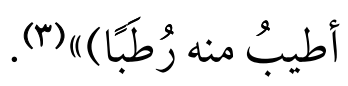

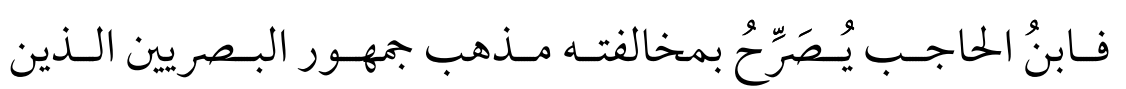

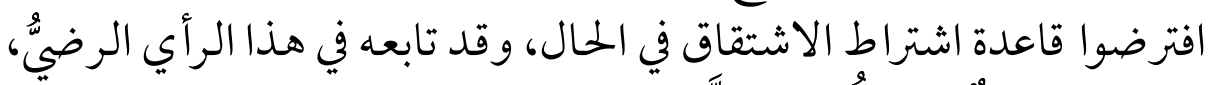

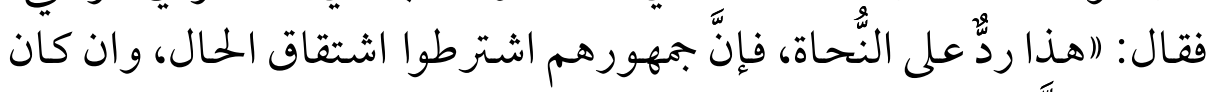

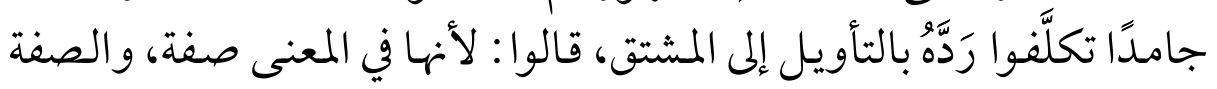

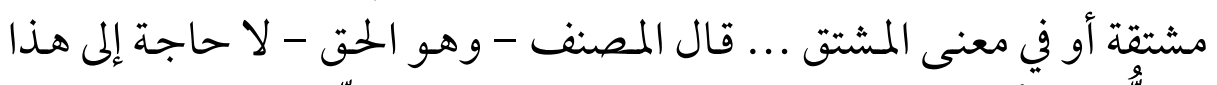

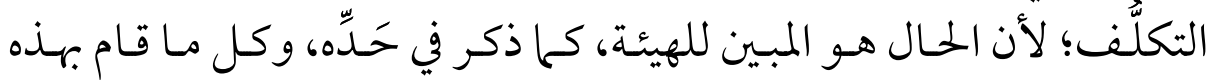

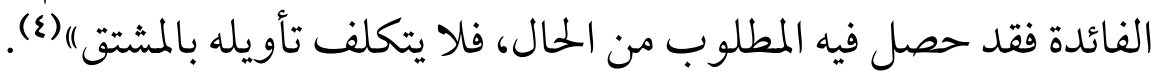




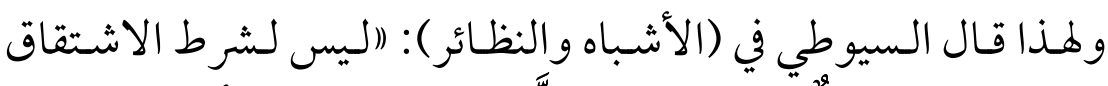

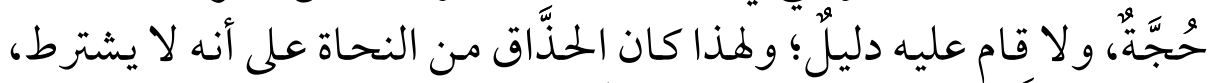

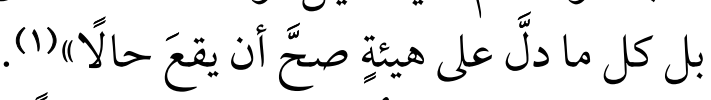

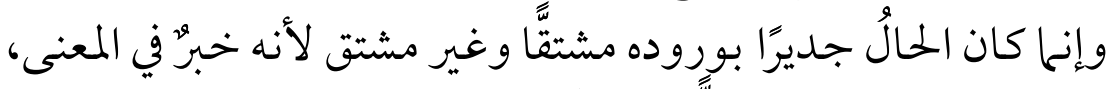

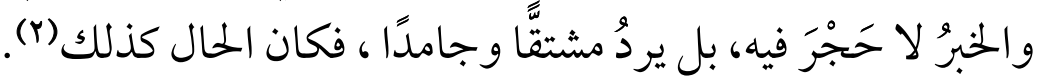

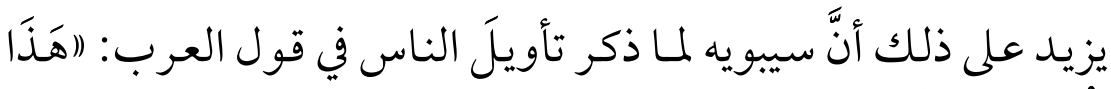

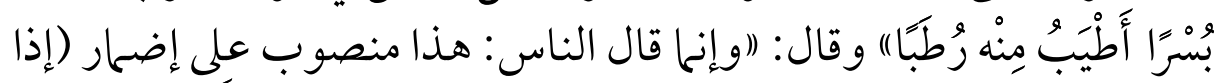

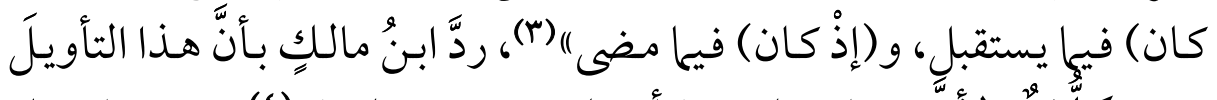

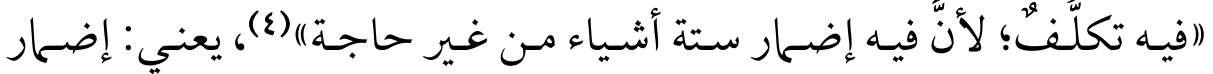

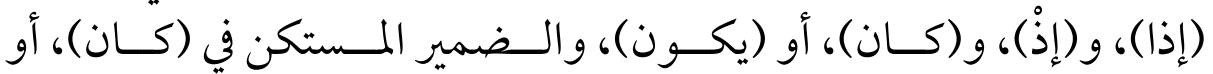
(يكون) (1) (1)

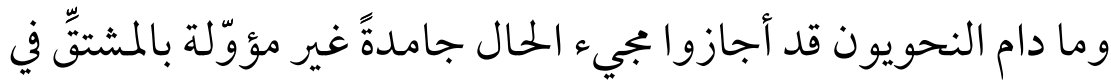

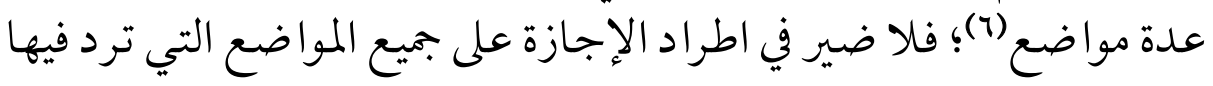

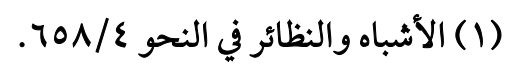

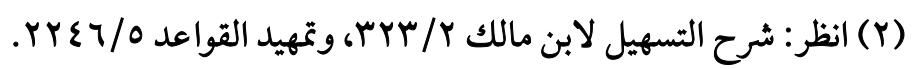

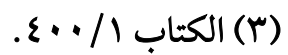

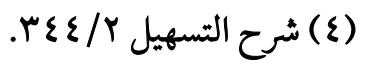

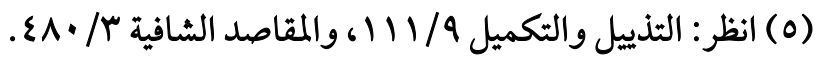

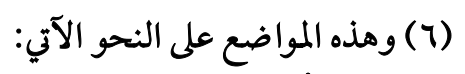

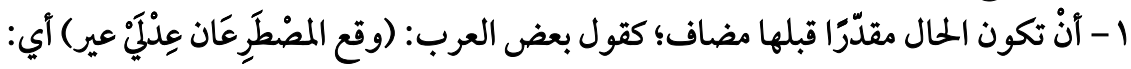

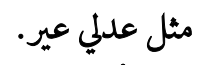

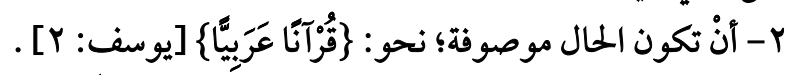

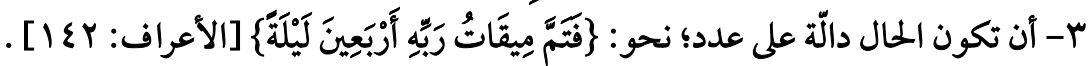

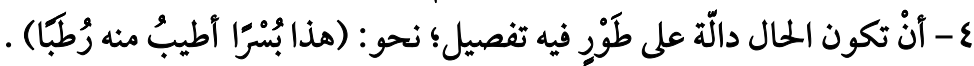

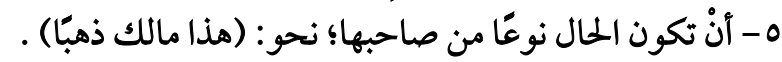

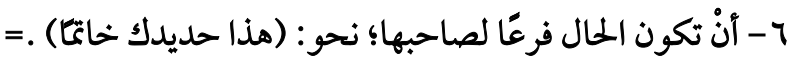


الحال بهذه الهيئة؛ إذ لو كان التحرُّز من التجويز من جهة أنه يؤثر في اهتزاز

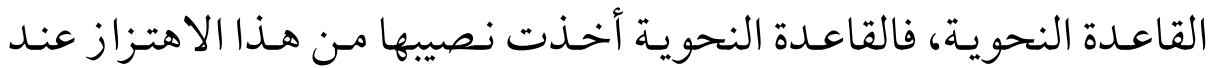

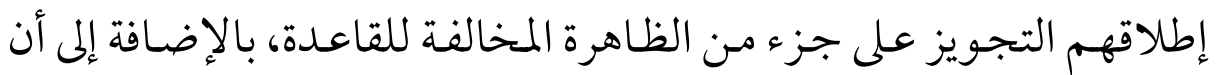

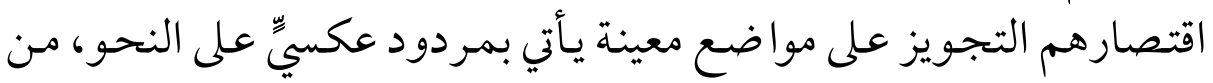

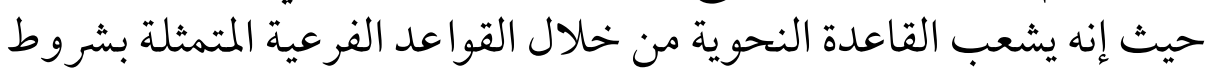

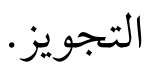

\section{ثانيًا: من حيث وقهع الجمبة الماضوية حالًا:}

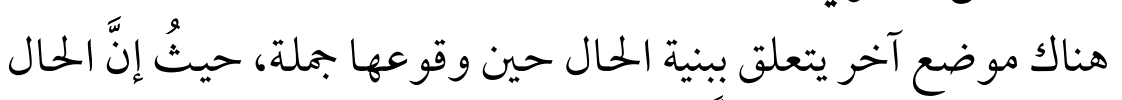

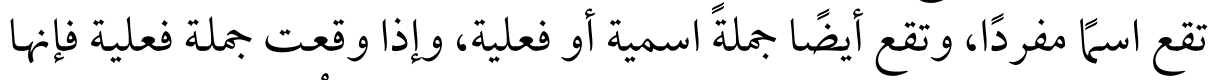

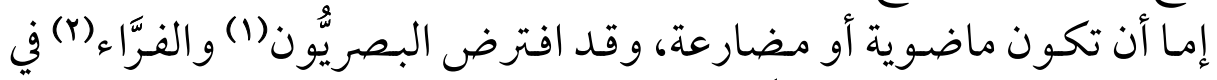
الجملة الماضوية الواقعة حالًا وجوب أنسارعة وقترانها بـ (قد).

V=

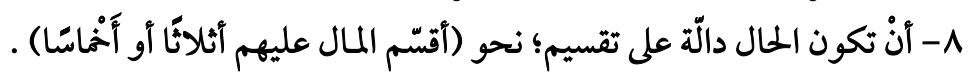

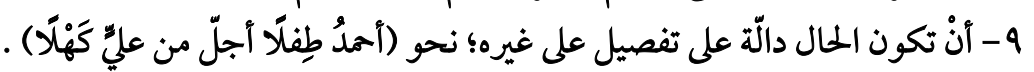

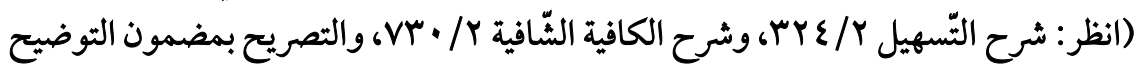

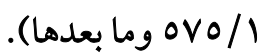

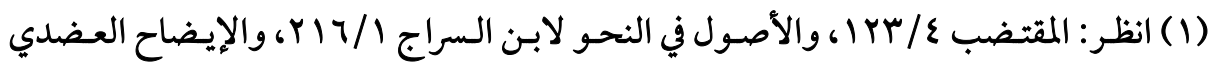

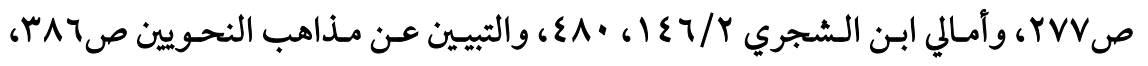

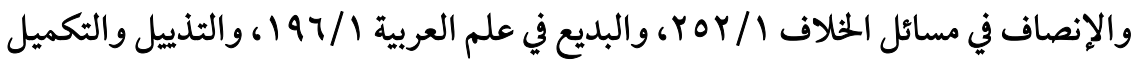
.119/9

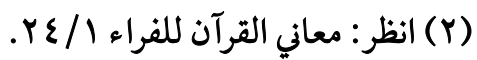




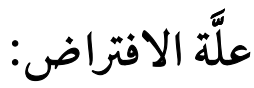

احتجوا لذلك من وجهين (1) الافتراف:

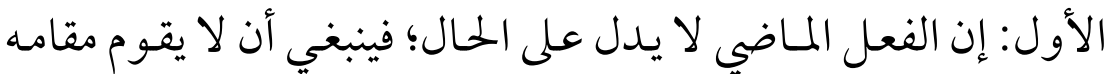

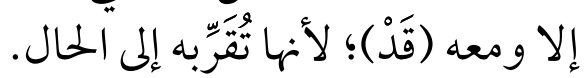

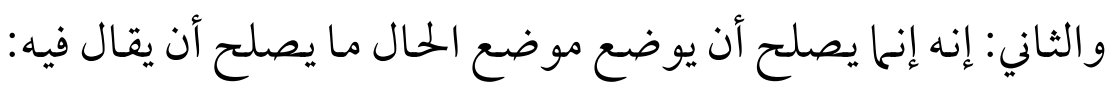

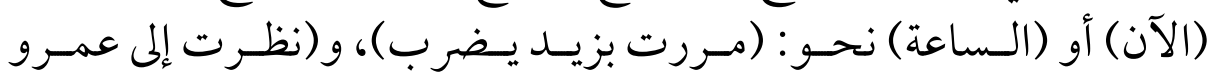

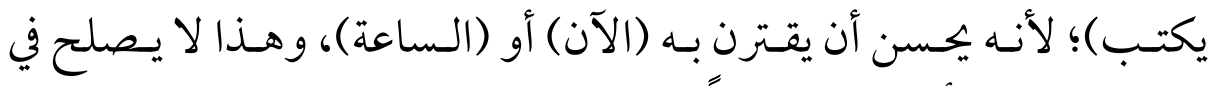
الماضي، فينبغي أن لا يكون حالًا.

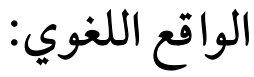

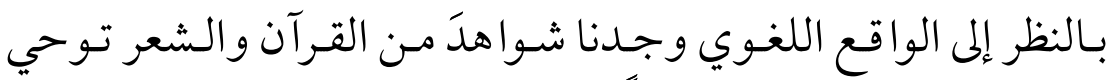

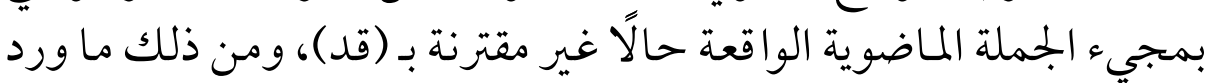
في القرآن المجيد:

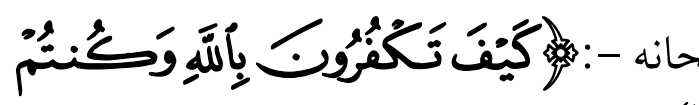

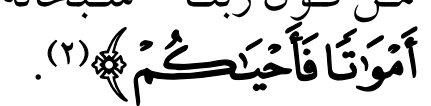

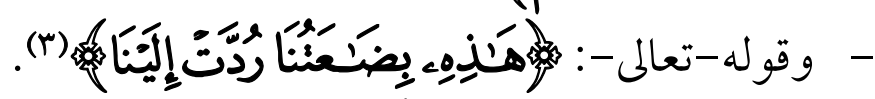

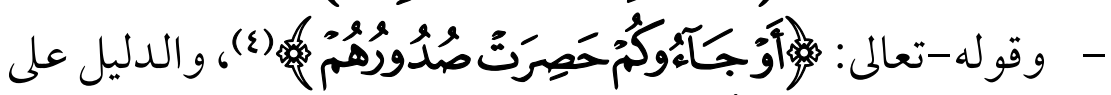

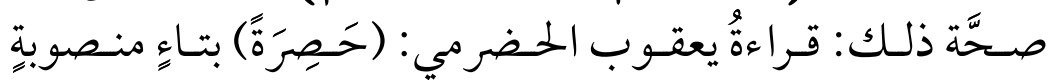

منوَّنة (0).

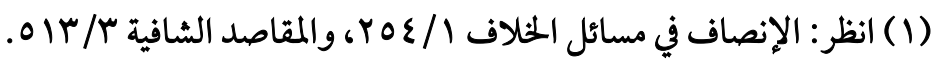

$$
\begin{aligned}
& \text { (Y) سورة البقرة، من الآية (Y) (Y) (Y). } \\
& \text { (Y) سورة يوسف، من الآية (Y) (Y) ). }
\end{aligned}
$$

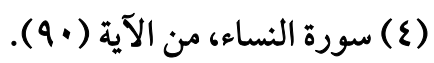

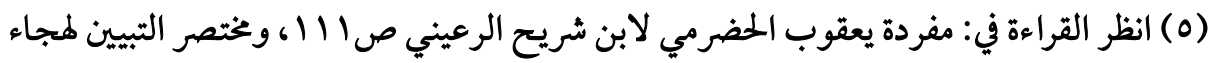

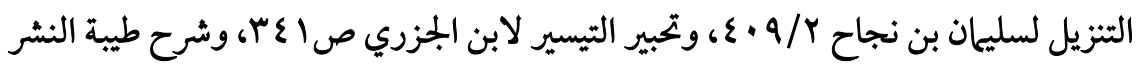




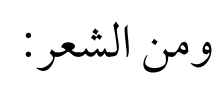

- قول قون امرئ القيس:

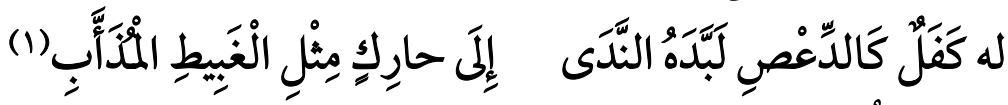

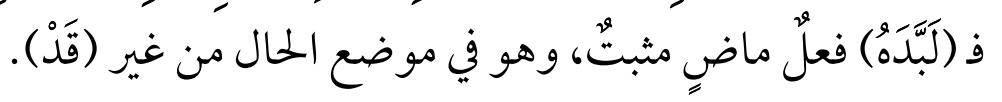
- موقوله أيضًا:

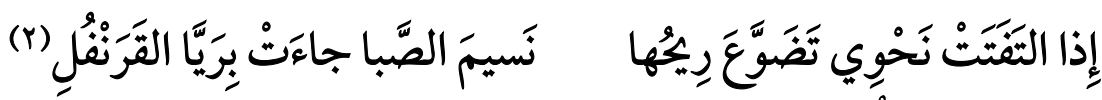

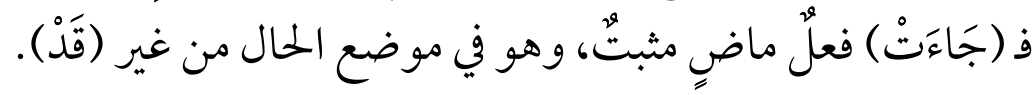

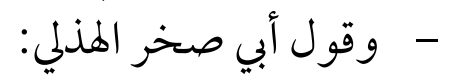

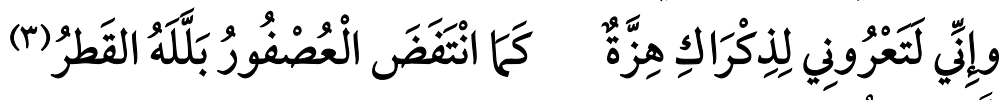

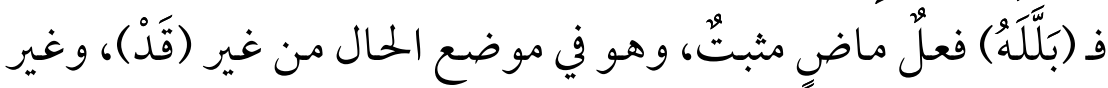

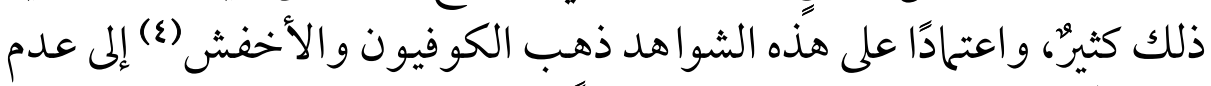

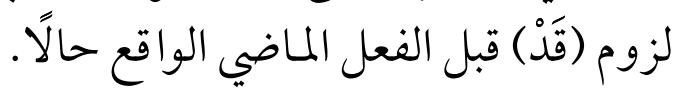

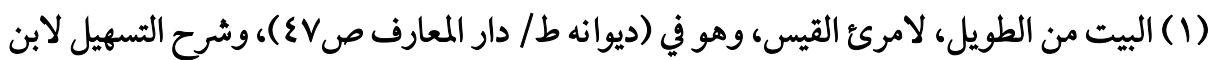

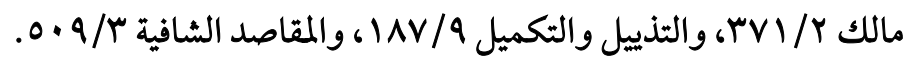

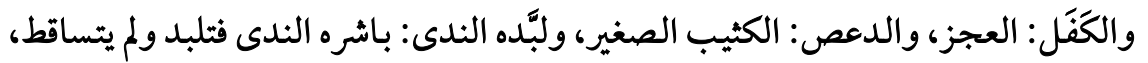

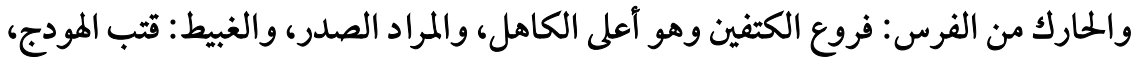

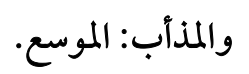

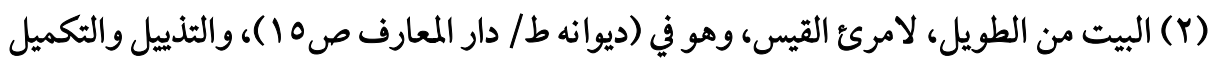

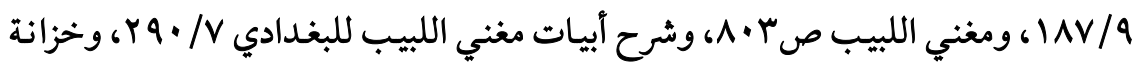

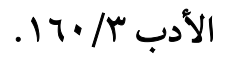

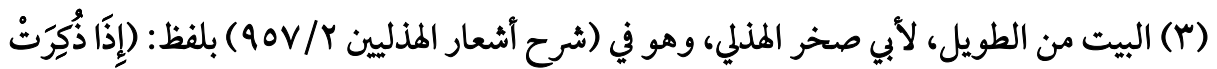

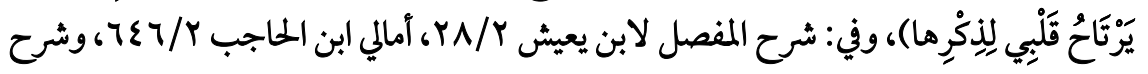

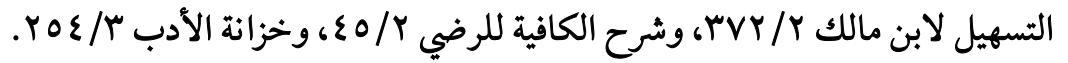

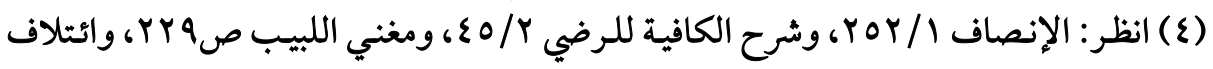

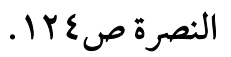




\section{صنيعة البصريين والفرًّاء مع هذه الشواهد:}

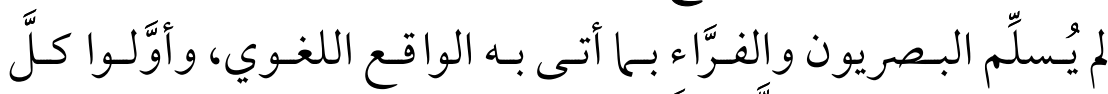

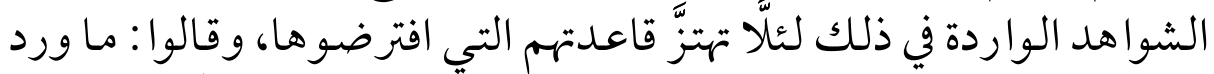

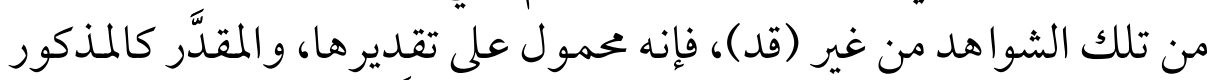

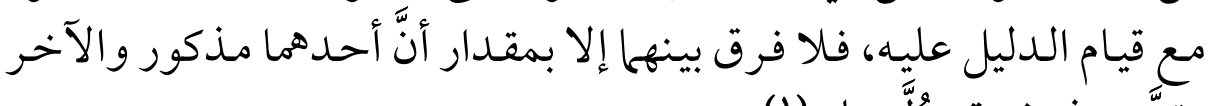

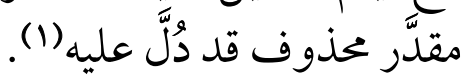

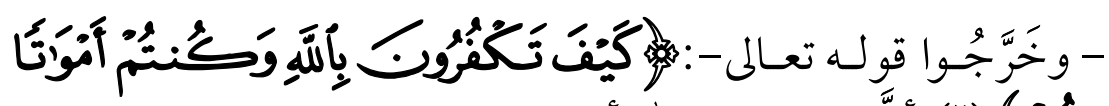

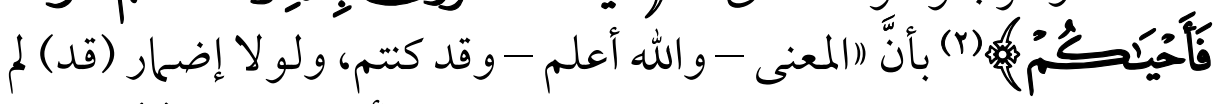

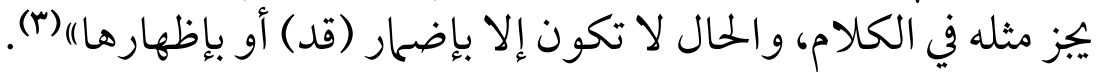

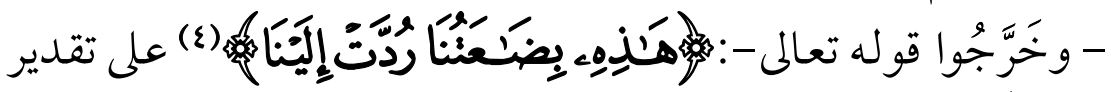

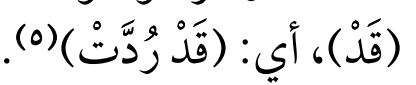

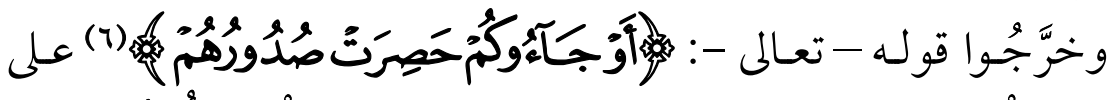

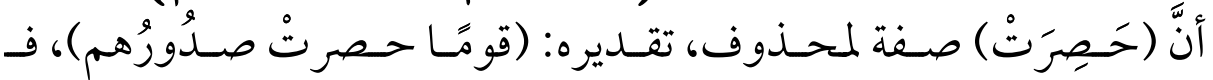

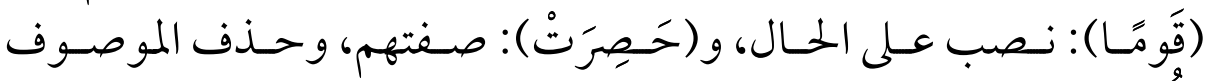

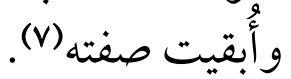

وقد ردَّ ابن مالك هذا التخريج بأنه ("تكلُّفُ شيءٍ لا حاجة إليه)|(().).

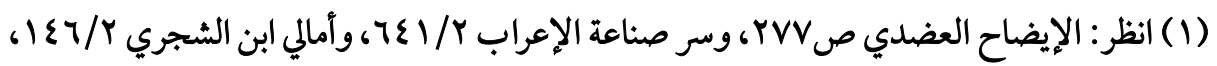

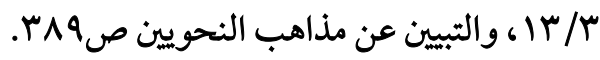

$$
\begin{aligned}
& \text { (Y) سورة البقرة، من الآية (Y) (Y). }
\end{aligned}
$$

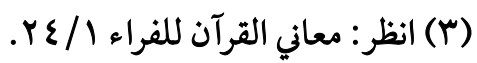

$$
\begin{aligned}
& \text { (ع) سورة يوسف، من الآية (70) (10). }
\end{aligned}
$$

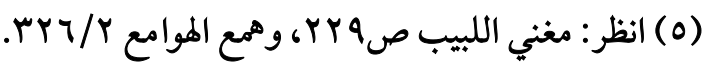

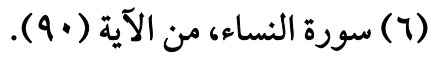

$$
\begin{aligned}
& \text { (V) انظر: شرح المفصل لابن يعيش (Y) }
\end{aligned}
$$

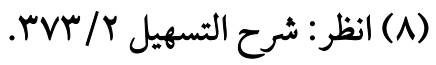




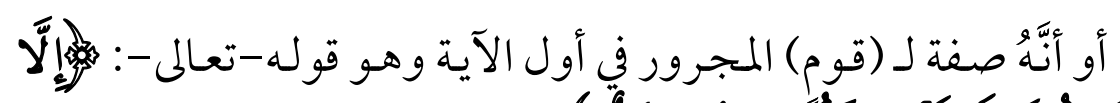

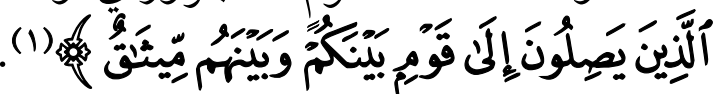

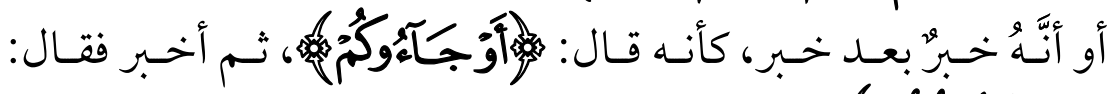

(r)

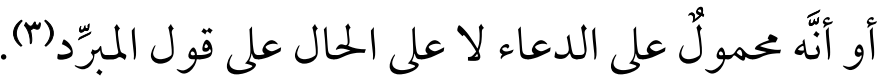

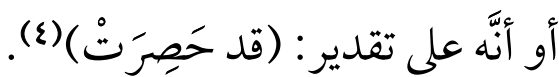

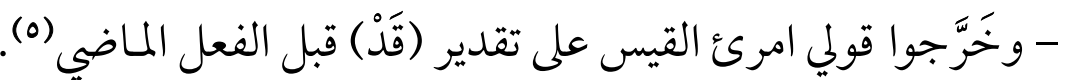

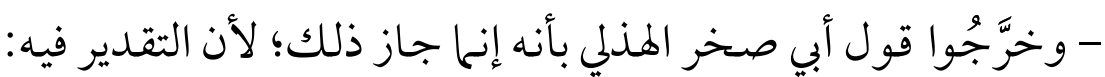

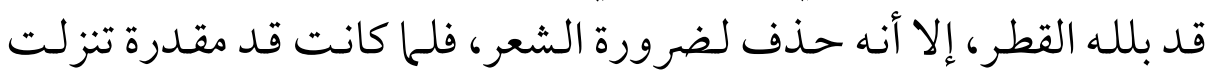

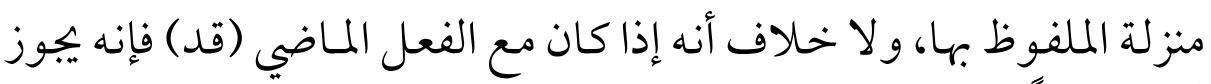

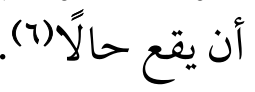

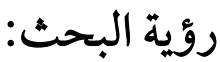

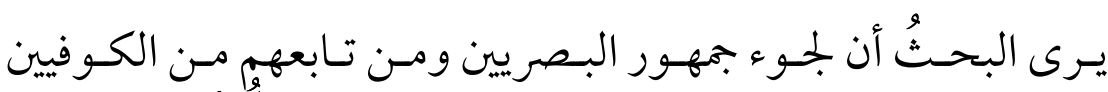

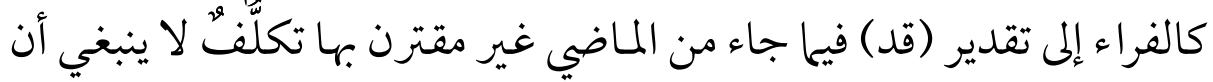

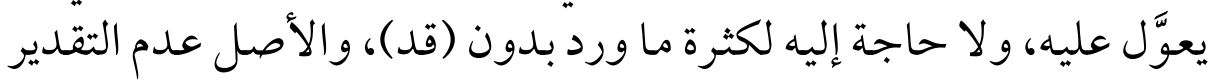

(1) سورة النساء، من الآية (•9)، وانظر : الإنصاف في مسائل الخلاف / /ع ب، وخزانة الأدب

$$
\text { .roo/r }
$$

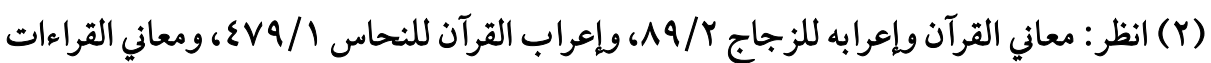

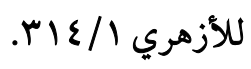

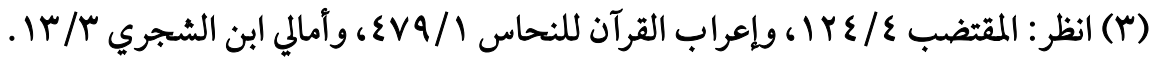

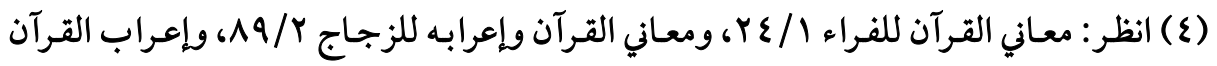

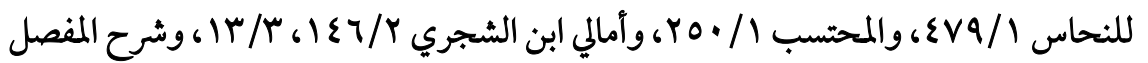

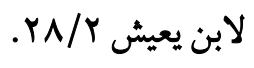

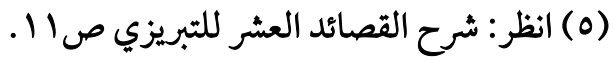

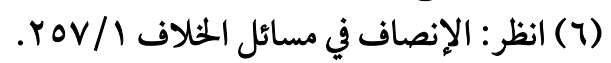


لا سيما فيما كثر استعماله؛ ولذا قال أبو حيَّان: (او الصحيح جواز ذلك لكثرة

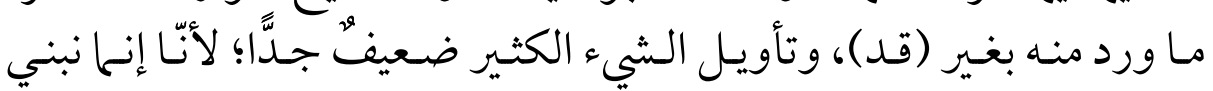

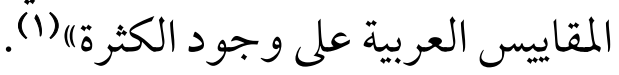

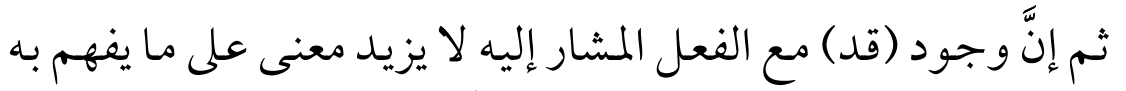

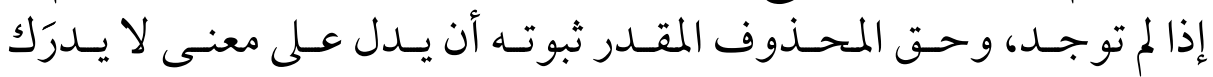

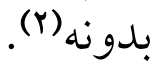

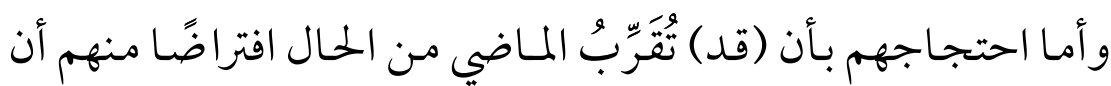

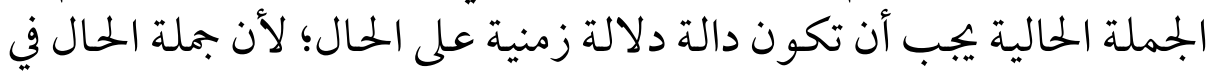

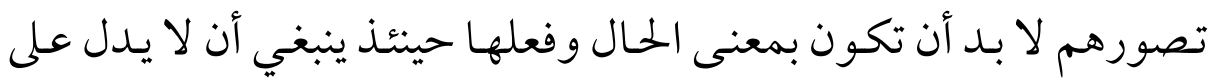

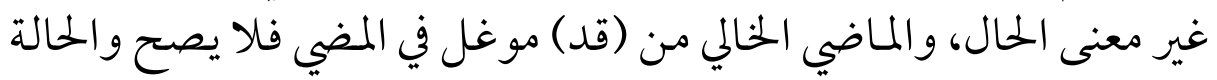

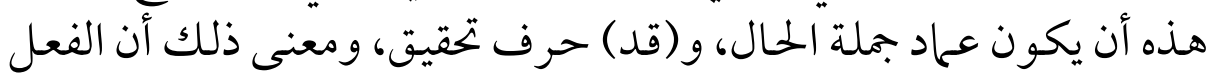

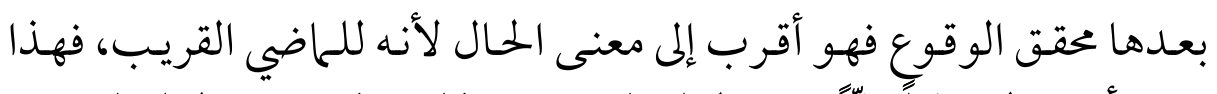

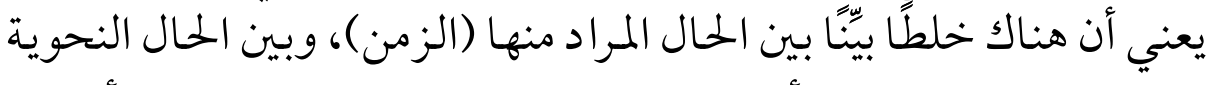

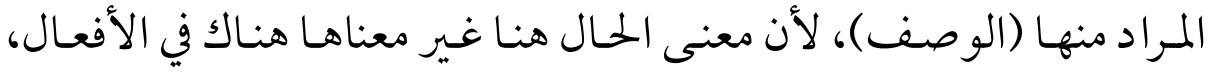

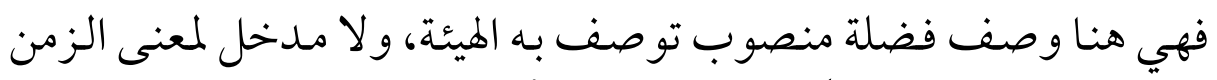

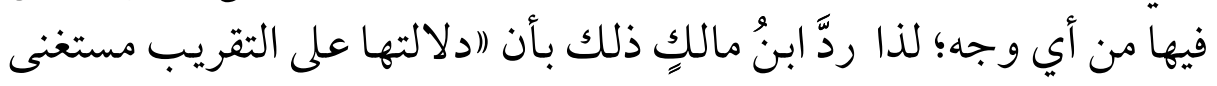

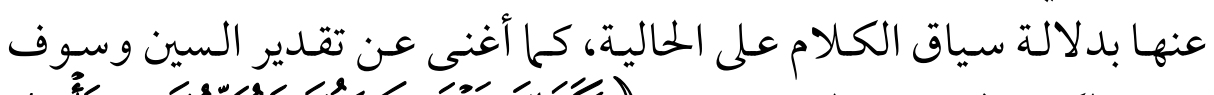

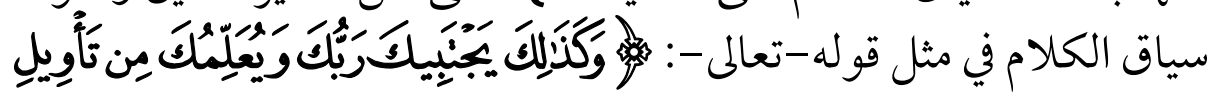

(1) التذييل والتكميل 1/9/9، وانظر: شرح ألفية ابن معطِ لابن القواس / / (1)، والمقاصد الشافية $.017 / \%$

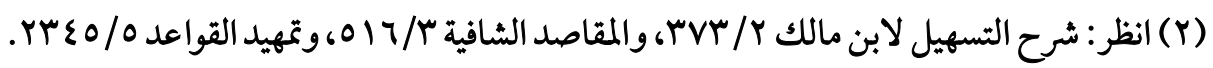




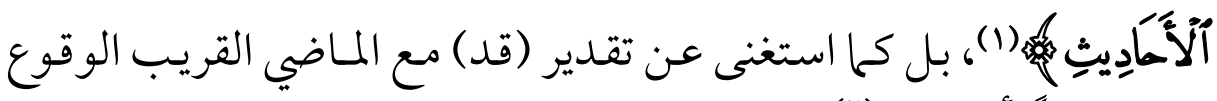

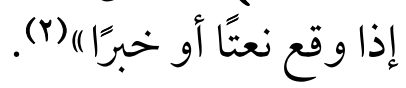

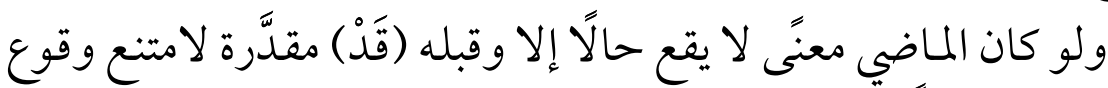

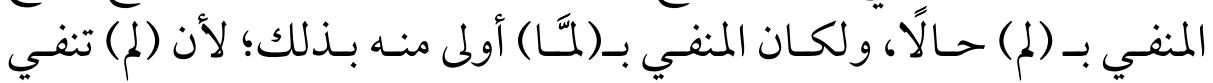

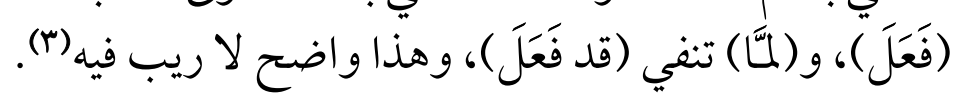

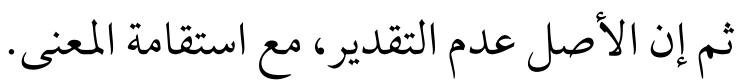

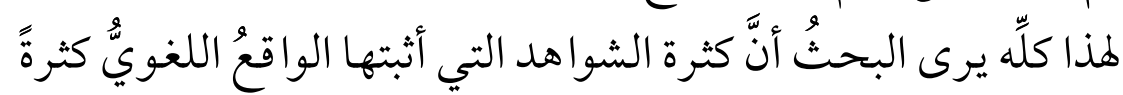

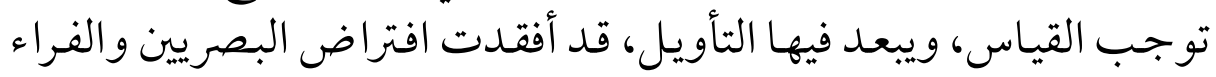

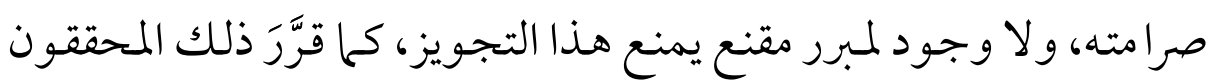

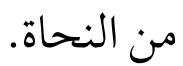

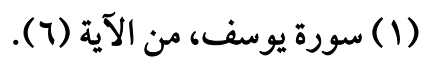

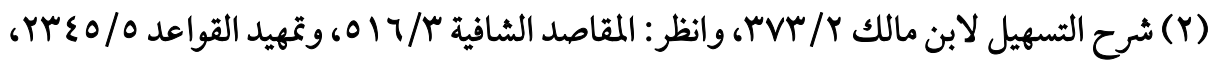

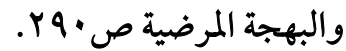

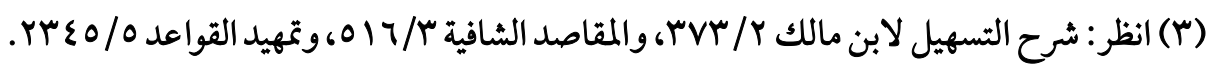




\section{المبــث الثالـث}

\section{صيغة المعمول هن هيـث الإعراب والبناء الإباء بين الافتراض النهوي والهواقع اللغوي هنوي}

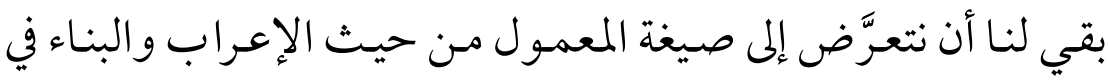

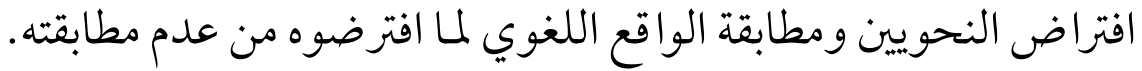

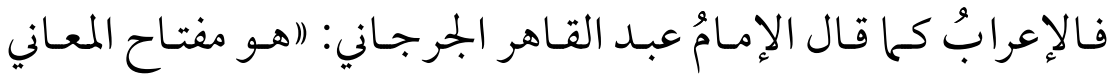

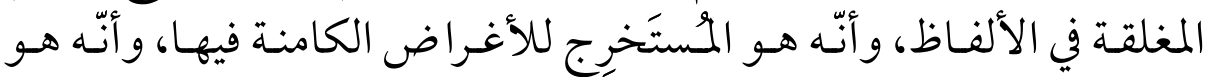

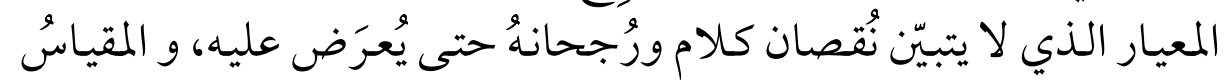

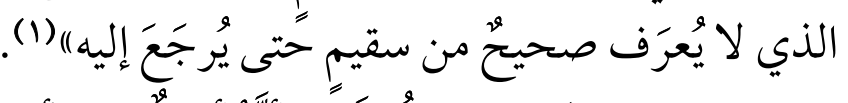

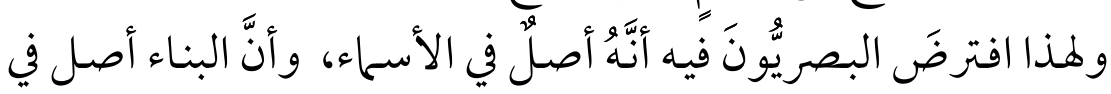

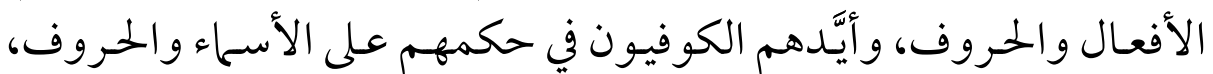

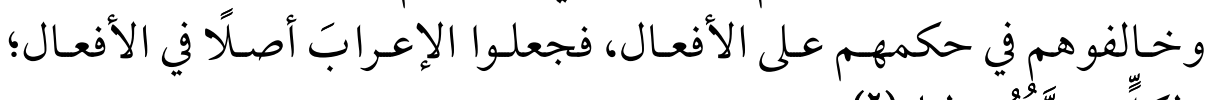

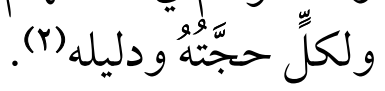

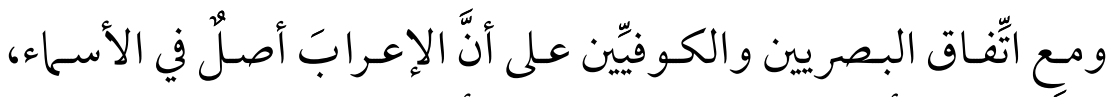

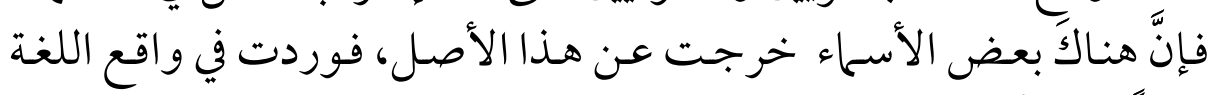

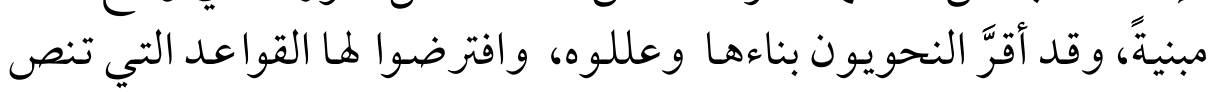

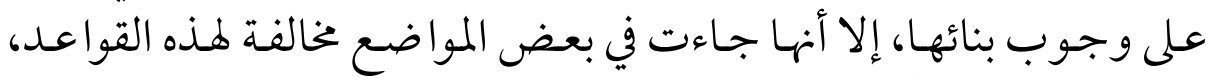

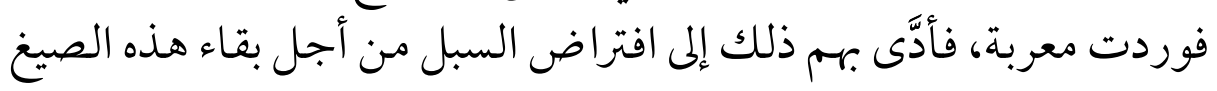

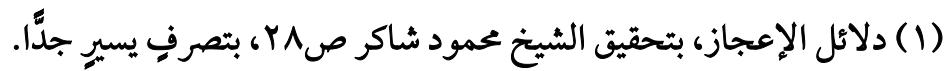

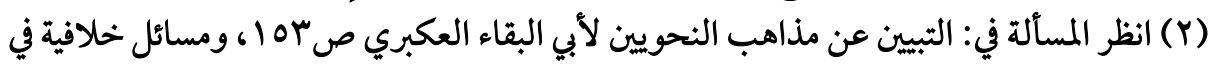

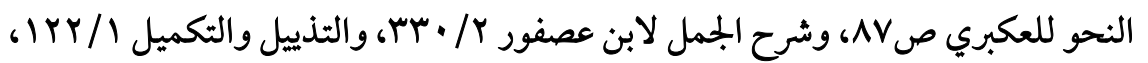

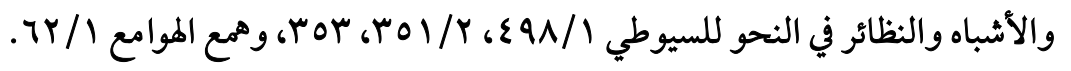


في داخـل الإطـار المقـرر للقاعـدة، وسـنعرض ذلك مـن خـالال النمـوذجين الآتيين: - n

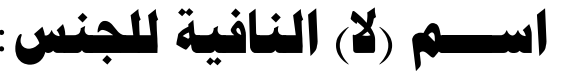

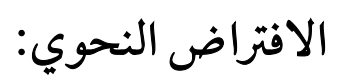

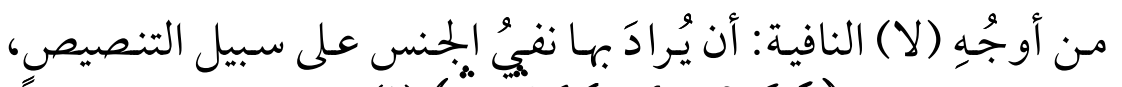

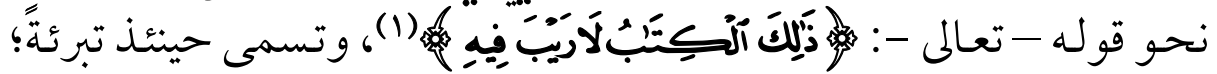
لدلالتها على البراءة من ذلك الجنس (r).

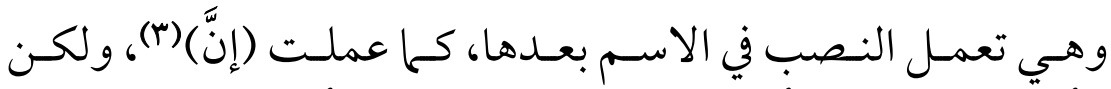

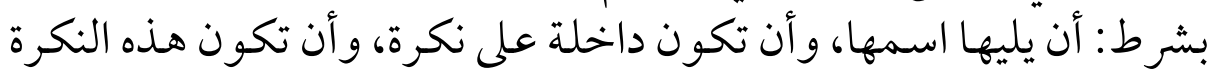

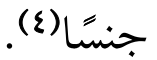

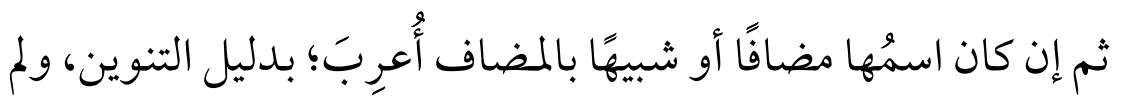

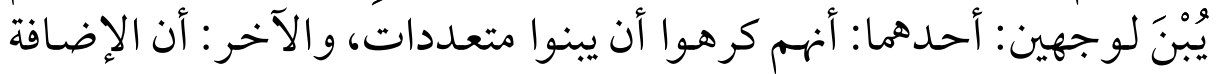

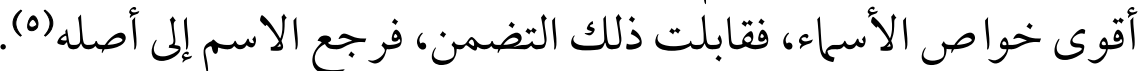

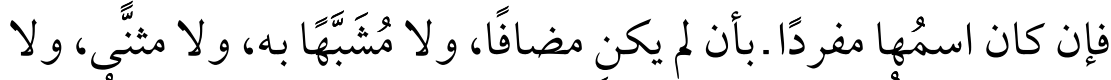

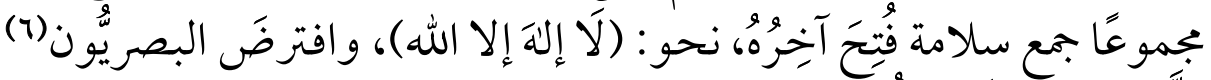

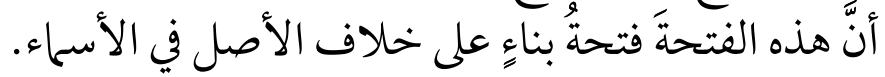

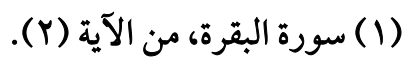

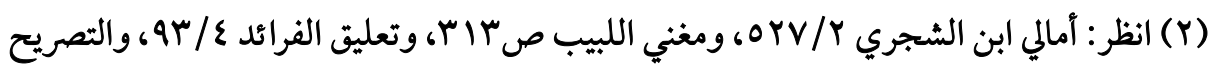
. rry/l

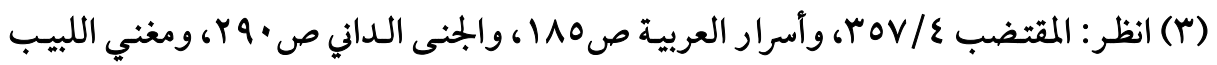

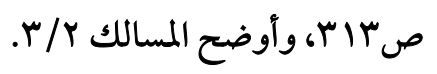

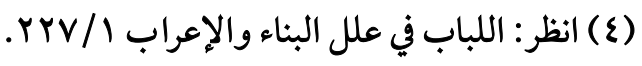

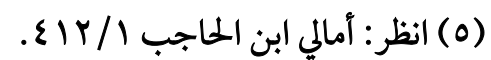

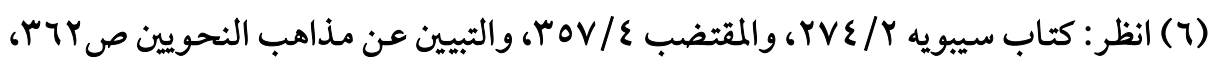

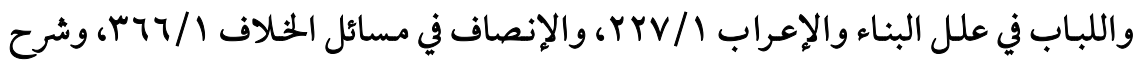

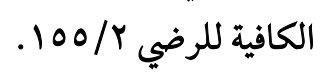




\section{علَّة الافتراض: - ماض}

وعلَّلوا لصحة افتراضهم هذا من وجوه(1):

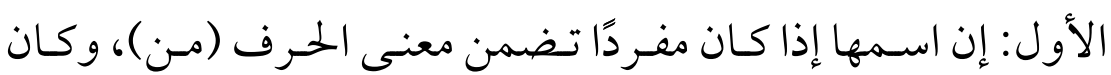

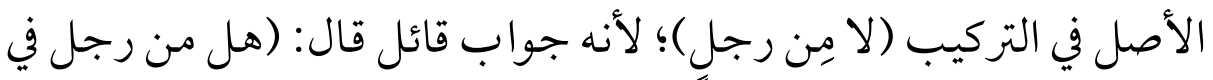

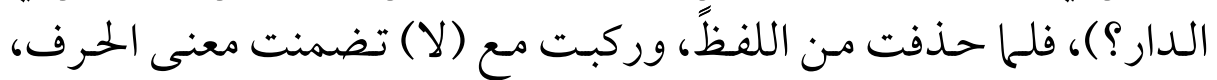

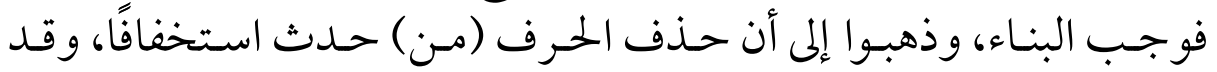

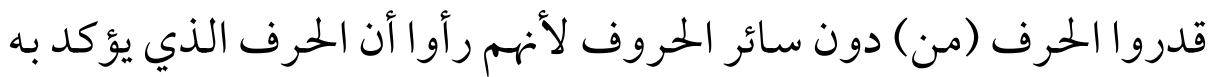
النفي هو (من)، فأوجبوا تقدير هونا.

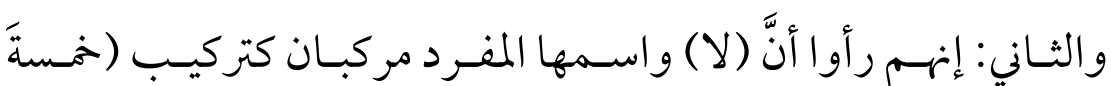

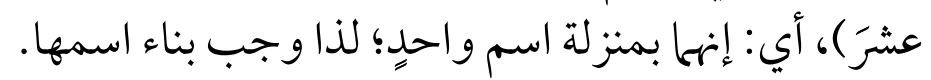

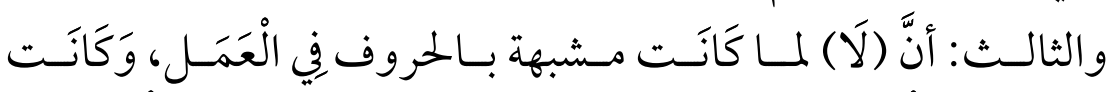

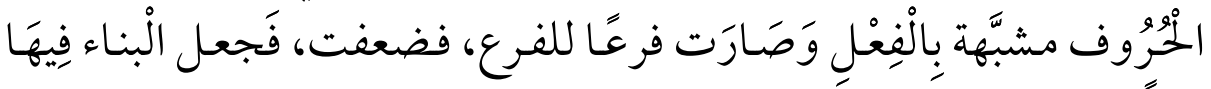

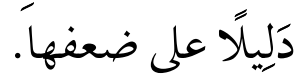

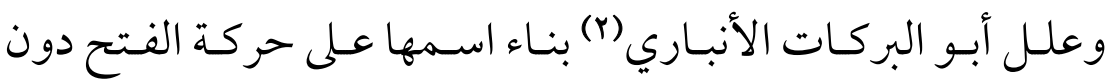
غيرها، من حيث إن الفتح أخف الخ الحركات الخاري. الواقع اللغوي:

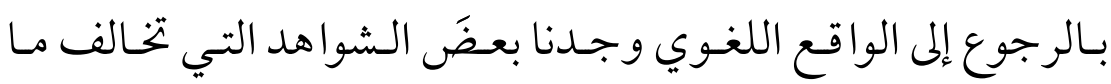

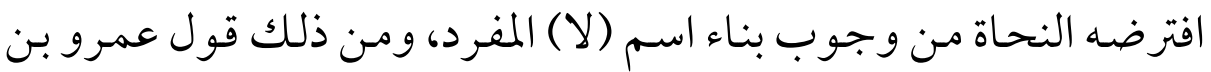
قعاس المرادي: - (فترضه النحاة مت

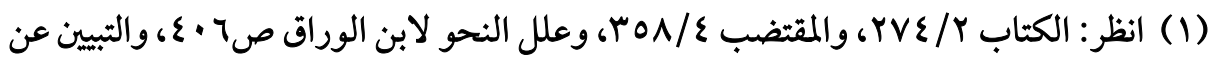

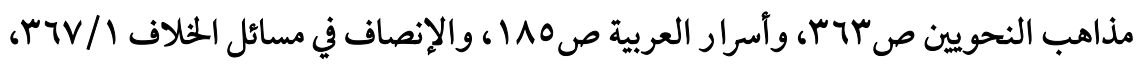

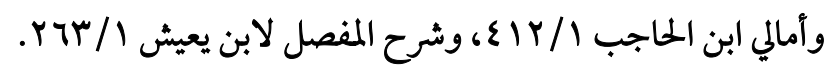

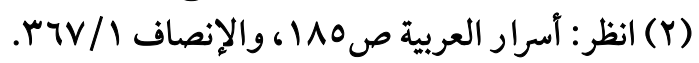




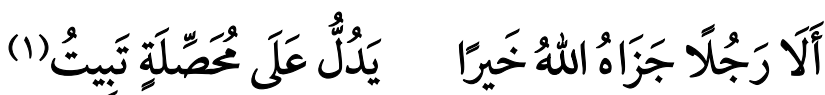

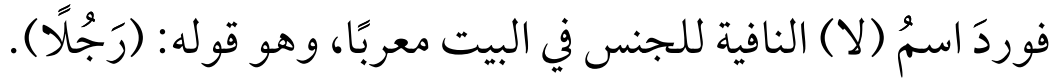

$$
\text { ومثله قول جرير: }
$$

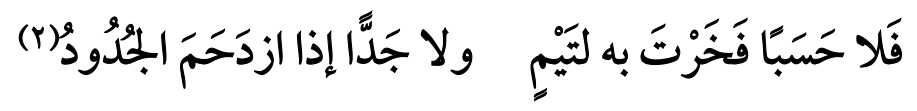

صنيعة البصريين مع هذه الشوا هد:

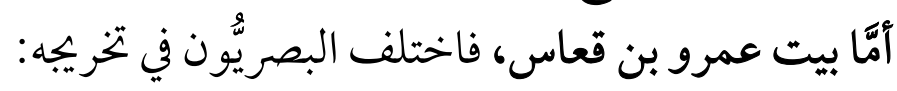

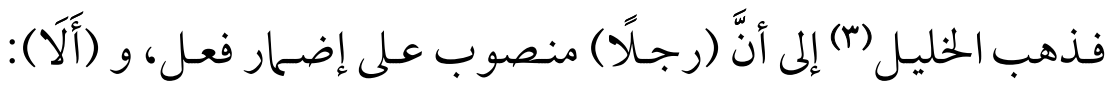

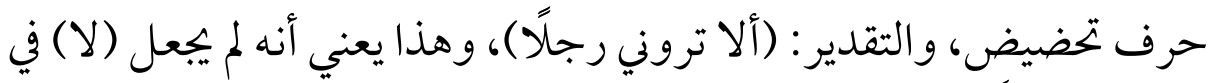

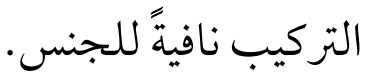

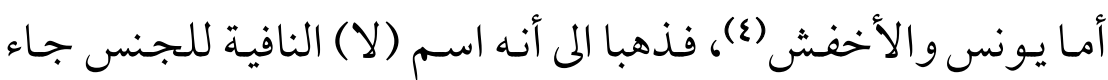

منصوبًا اضطرارًا.

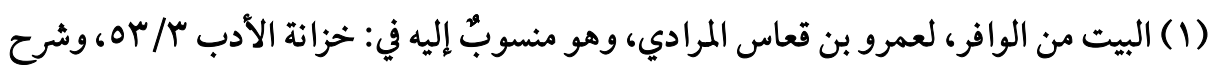

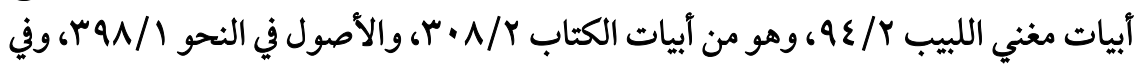

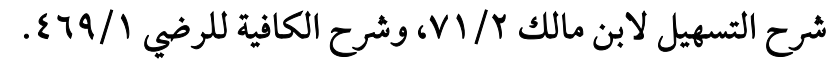

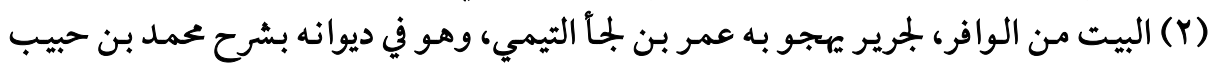

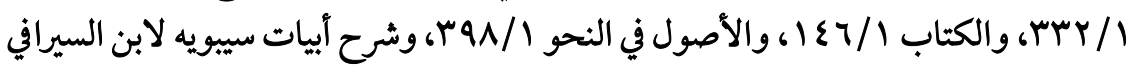

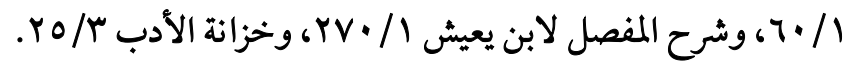

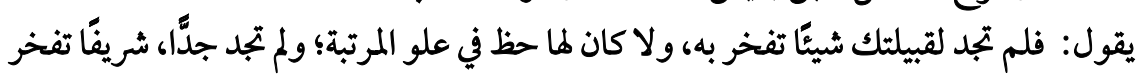

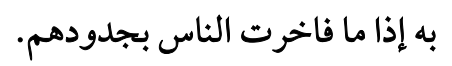

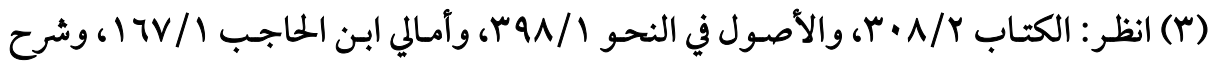

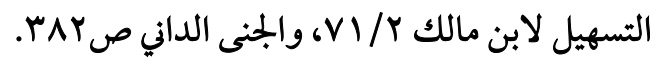

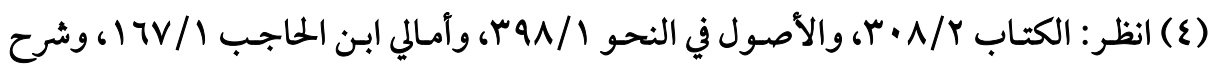

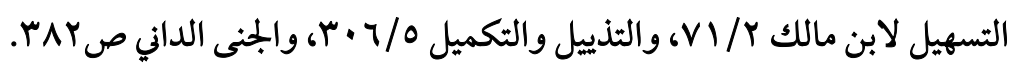




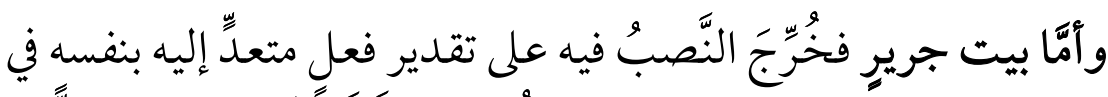

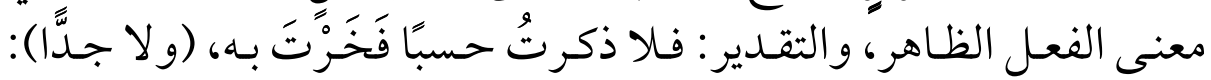
معطوف على قوله: (حَسَبًا) (1).

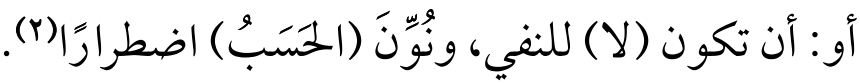

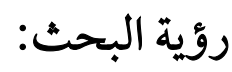

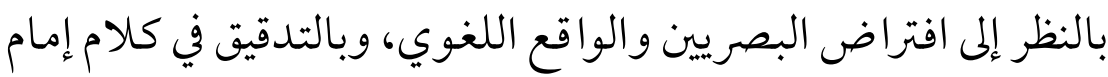

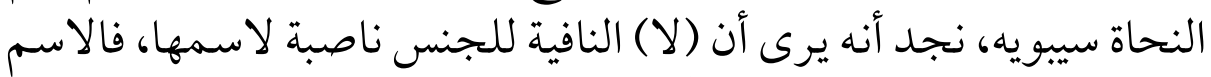

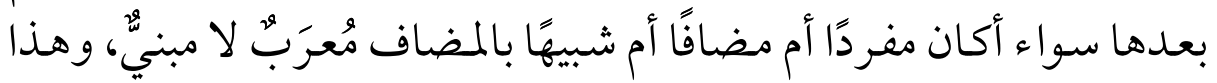

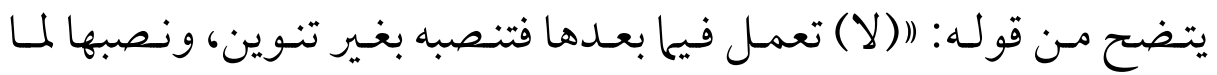

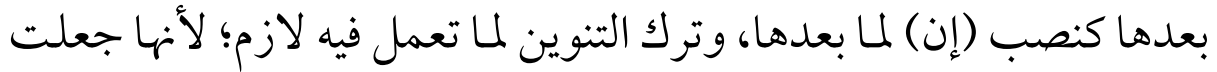

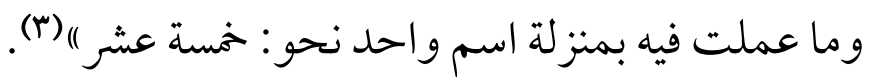

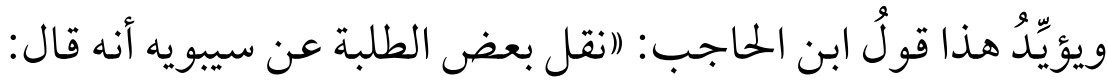

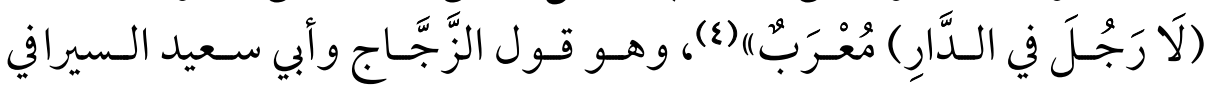

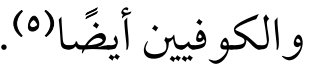

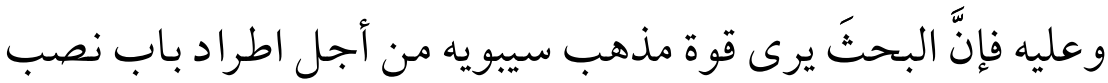

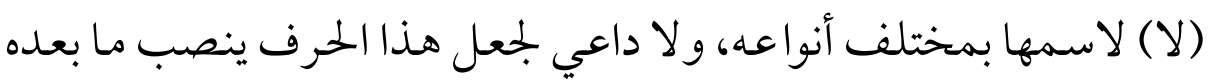

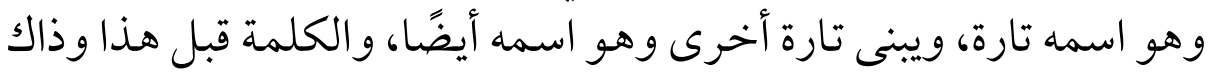

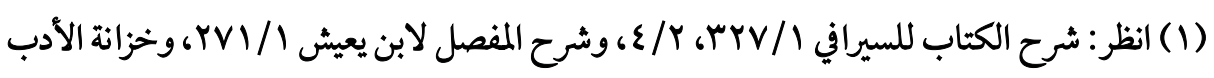
ro/r (Y) انظر : شرح الكتاب للسيرافي Y/Y ع. ع.

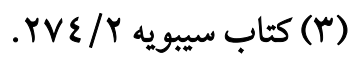

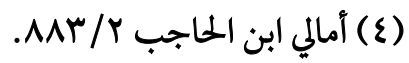

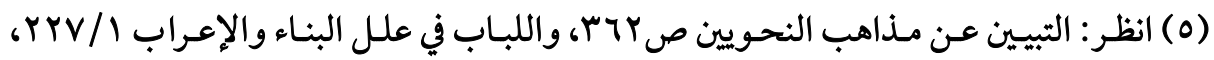

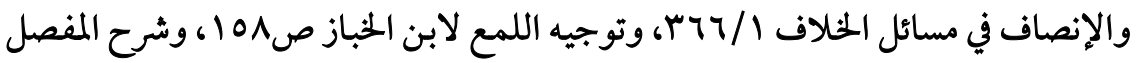

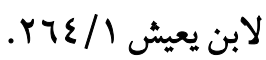


واحدة وهي متمكنة في الإعراب وليست مبنية، ثم إننا لم نجد ناسخًا مـن

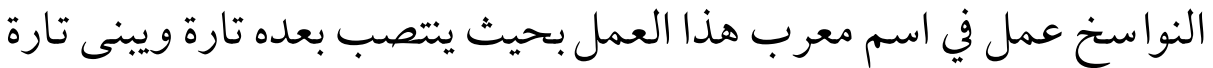

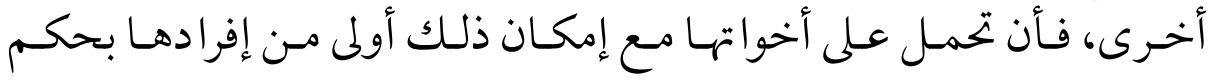
غريب.

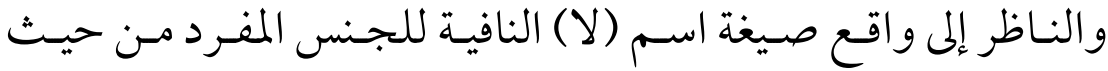

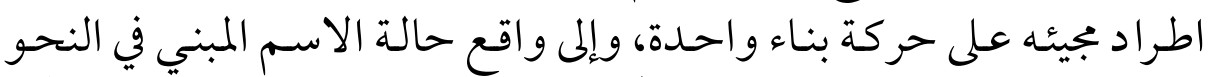

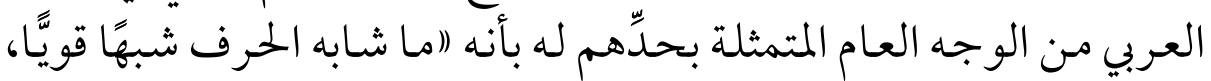

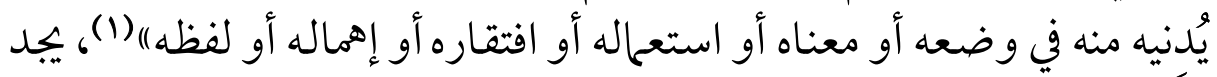

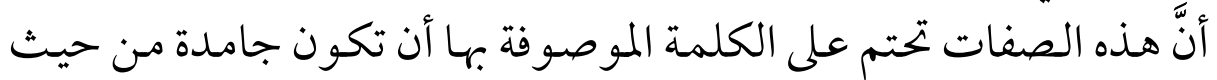

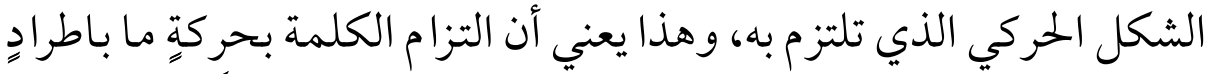

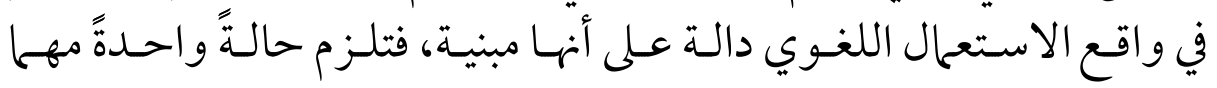
تعددت العوامل الداخلة عليها.

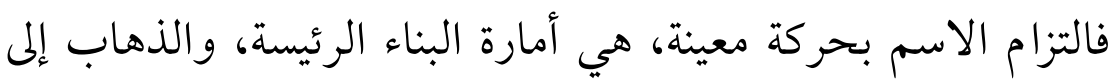

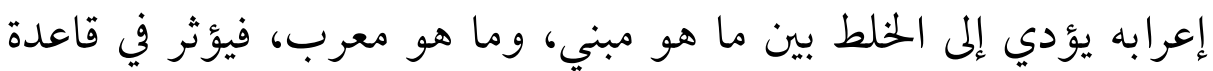

والأجدر التماس الطريق الأسهل، الذي يتم به الحصول على أكبر قدر

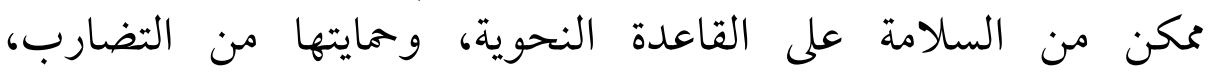

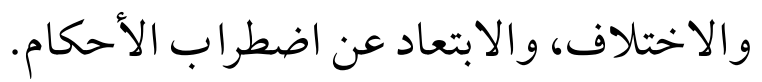

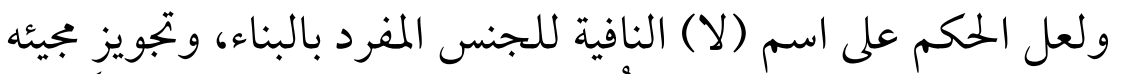

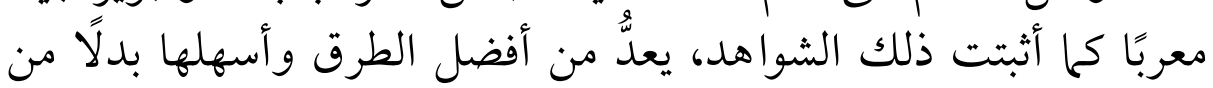

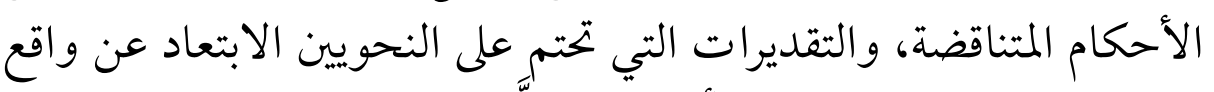

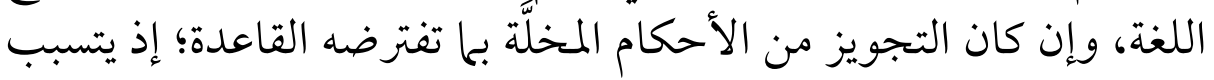

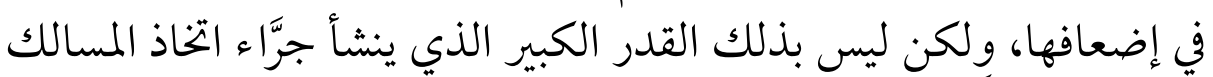
الأخرى المتكلَّفة. 


\section{العددد المركبـب:}

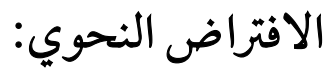

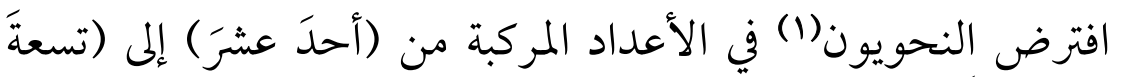

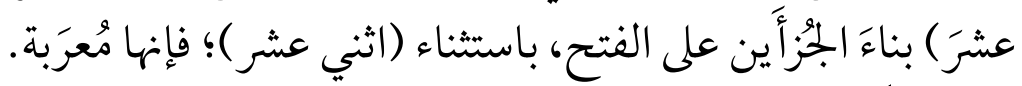

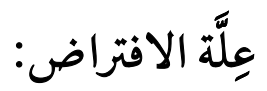

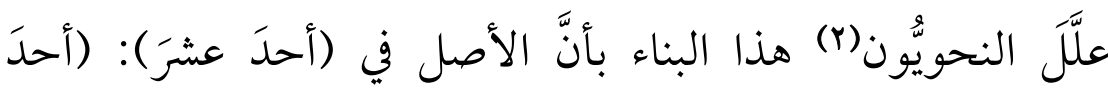

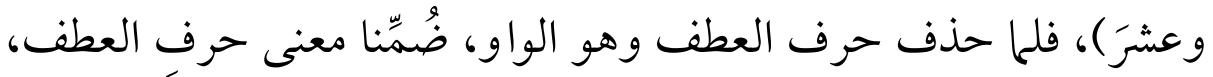

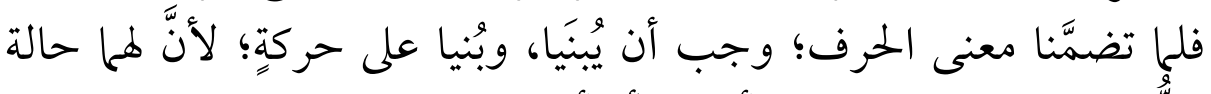

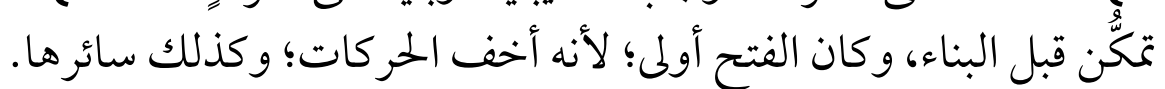

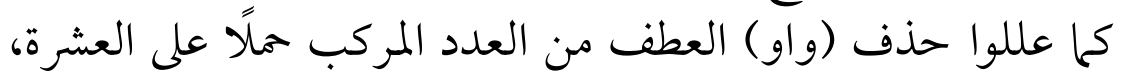

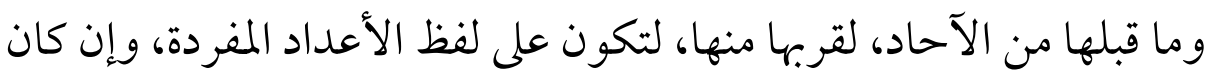

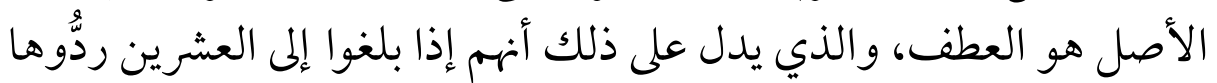

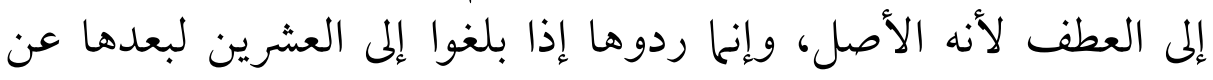
الآحاد) (r).

$$
\text { وعلَّلوا عدم بناء (اثْنَنِنِ) في (اثْنَيْ عَشَرَ) لوجوه: }
$$

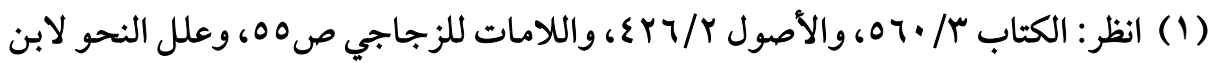

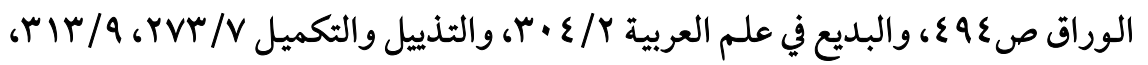

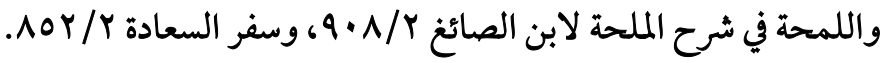

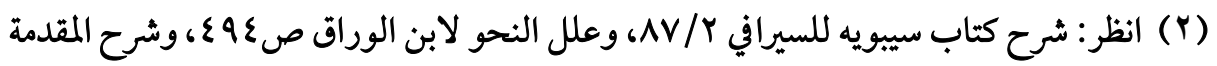

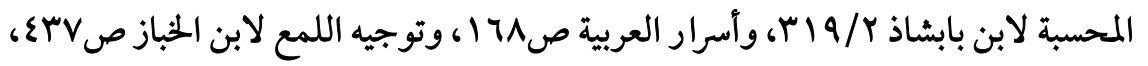

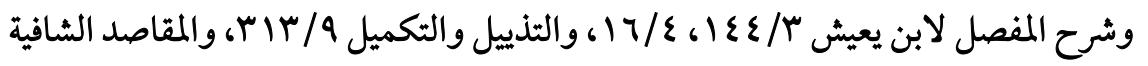




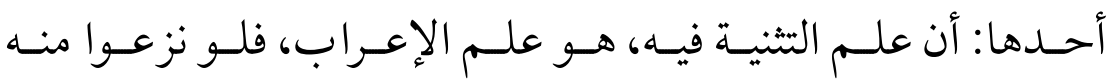

الإعراب؛ لسقط معنى الثثنية (1).

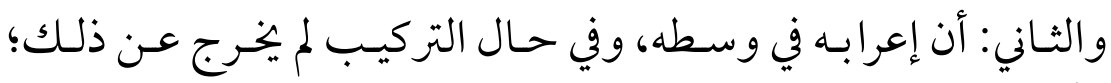

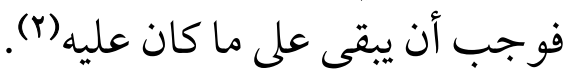

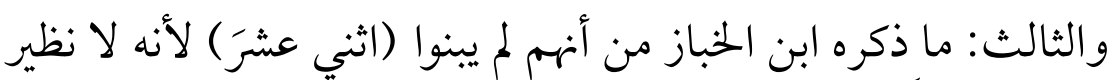

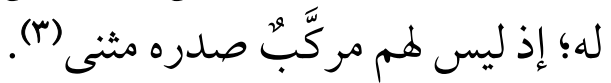

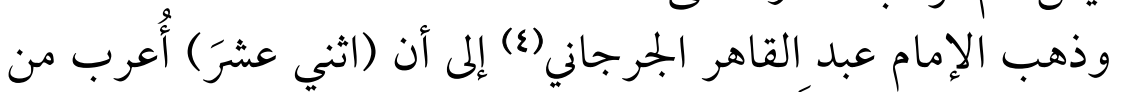

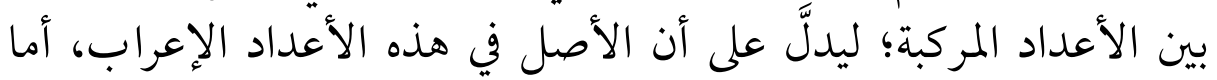

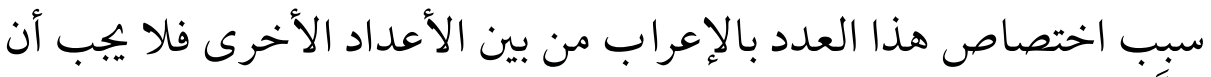

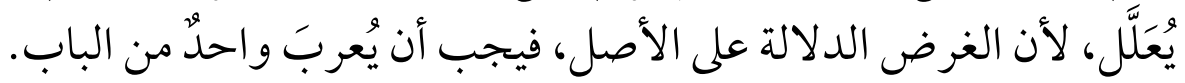

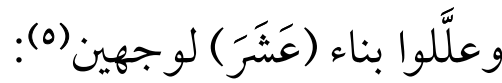

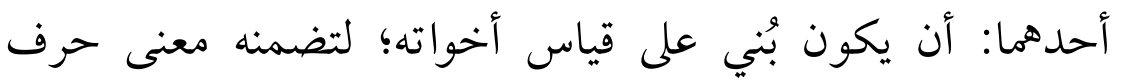

العطف.

و الثاني: أن يكون بُني؛ لأنه قام مُقام النُون من (اثنين)، فلما قام مُقام

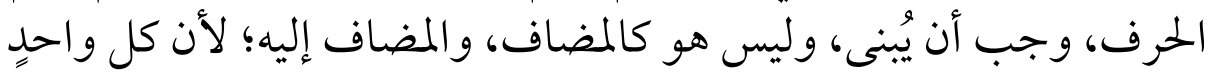

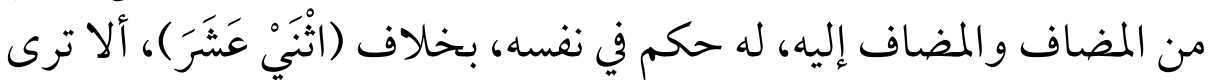

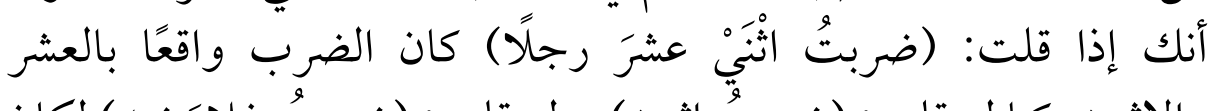

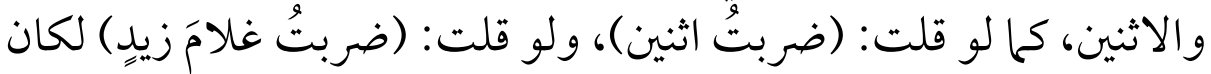

(1) (1) انظر: أسرار العربية ص171)

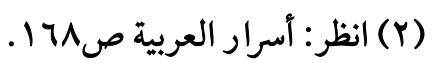

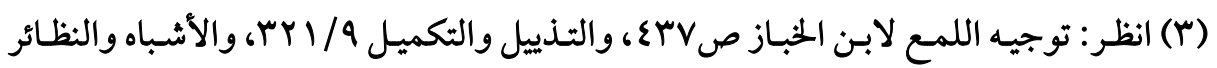

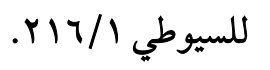

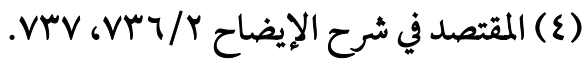

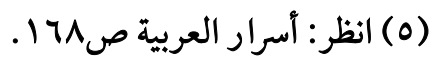


الضرب واقعًا بالغلام دون زيد؟ فلهذا، قالوا: إن العشر قام مُقام النون، وخالف المضاف إليه.

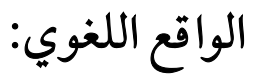

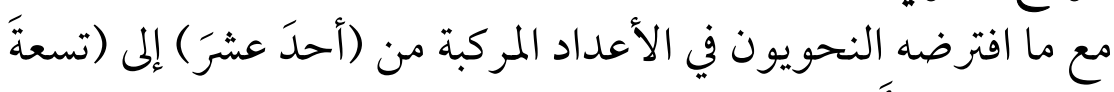

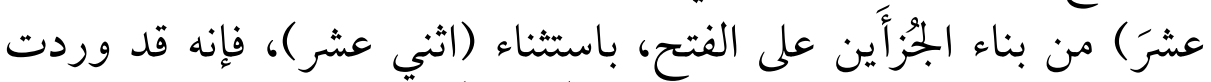

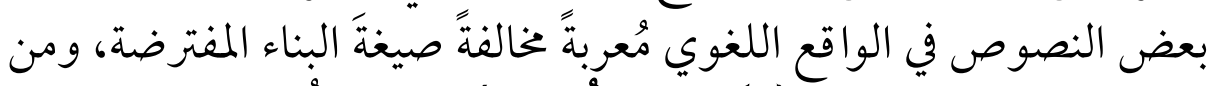

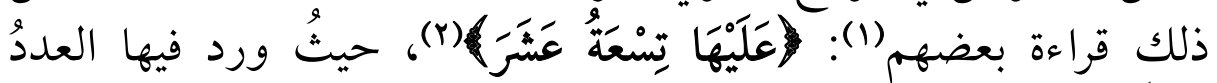

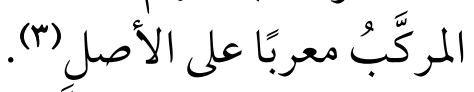

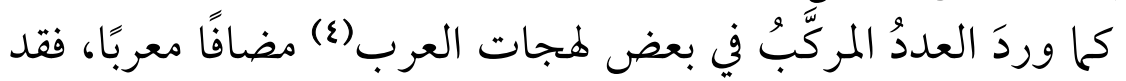

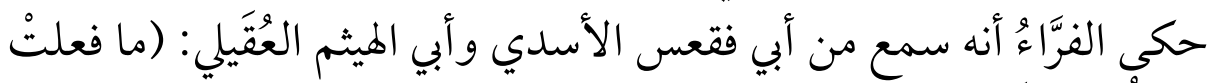

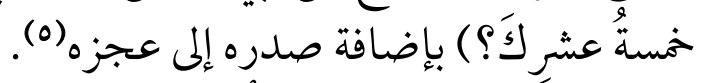

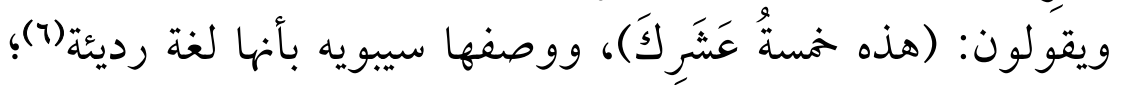

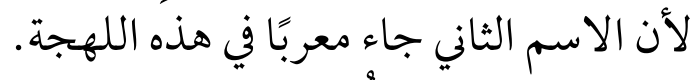

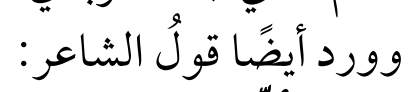

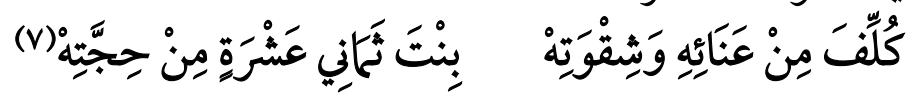

(1) هما ابن عباس، وابن قطيب. (انظر : ختصر في شواذ القرآن ص070 1، وشواذ القراءات للكرماني

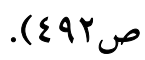

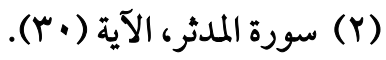

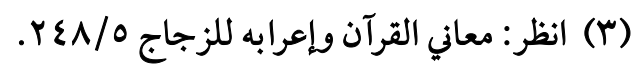

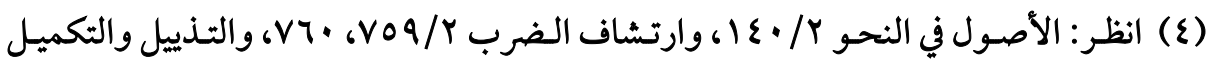

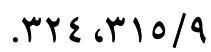

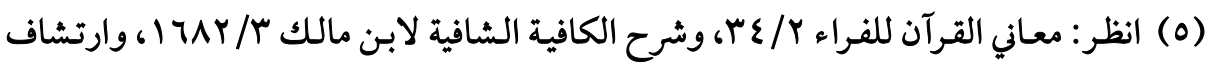

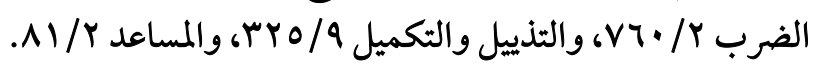

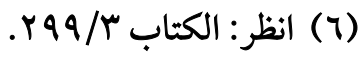

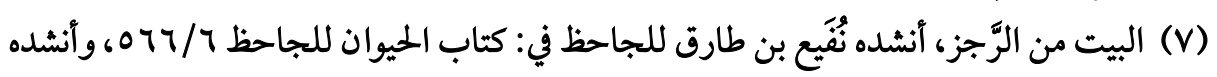

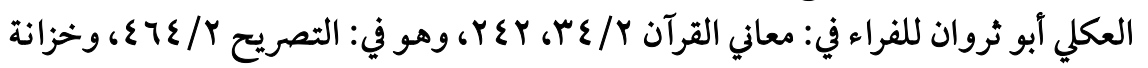

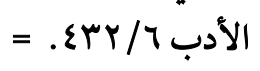




$$
\text { فجاء العدد المركب (ث) وني عشرة) مضافًا معربًا. }
$$

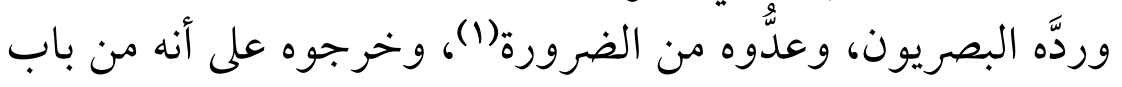

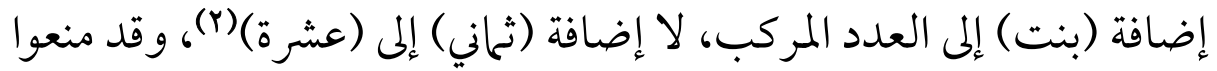

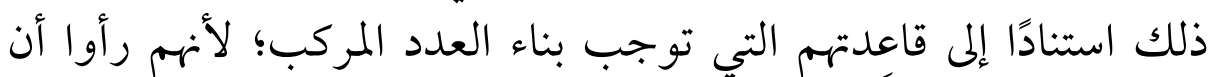

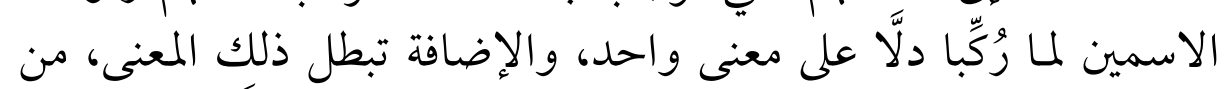

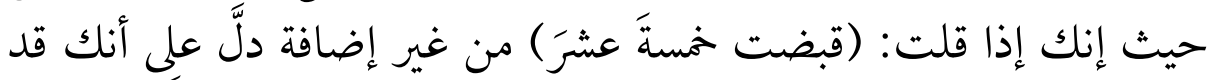

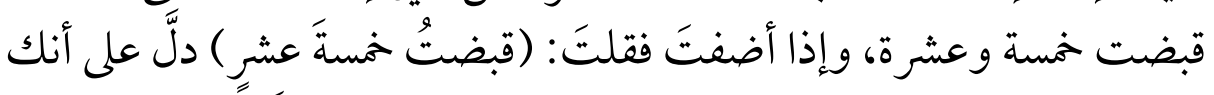

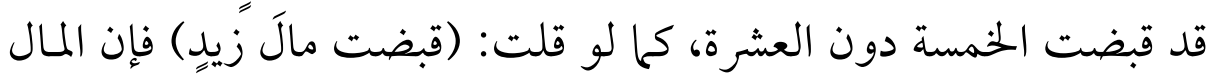

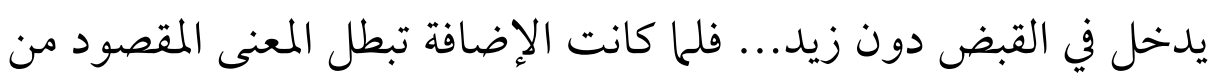

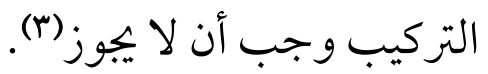

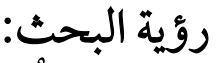

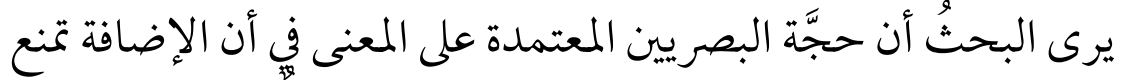

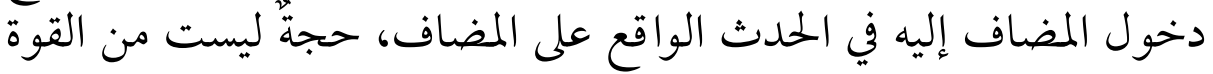

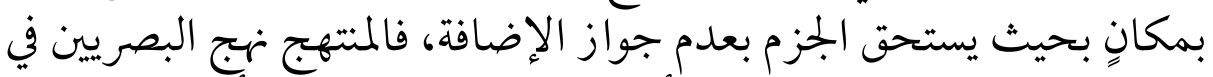

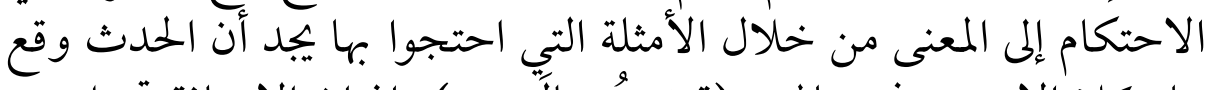

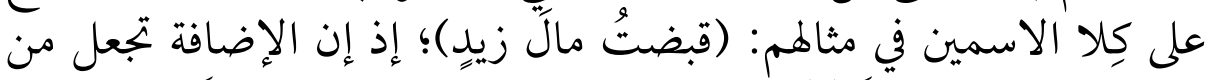

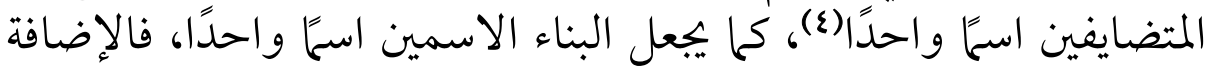

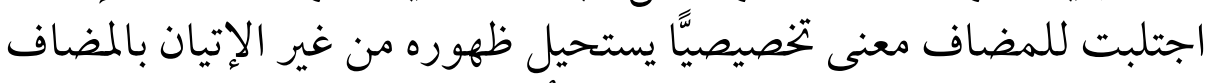

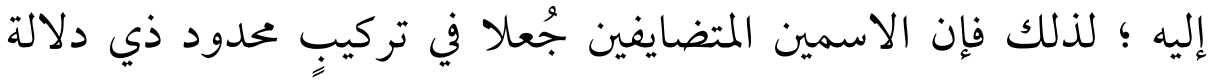

$$
\text { = والعناء: التعب، والشّقّوة: الشقاء، والِِجَّة: السَّنة. }
$$

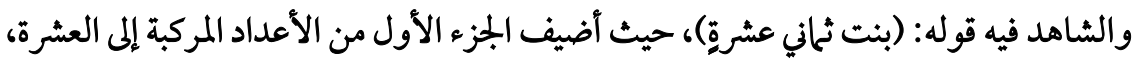

$$
\text { فقال عشرة بالجر والثنوين. }
$$

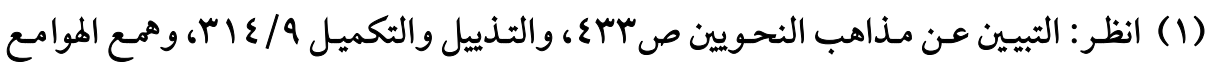
roT/r

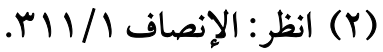

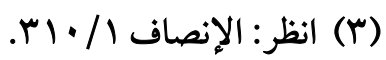

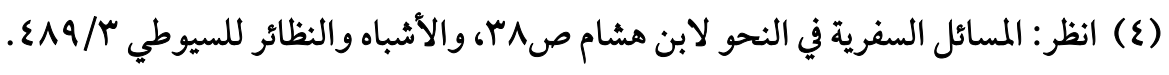


واحدة، فإجازة إضافة العدد المركب في ضوء مثال البصريين (قبضت مالَ الآ

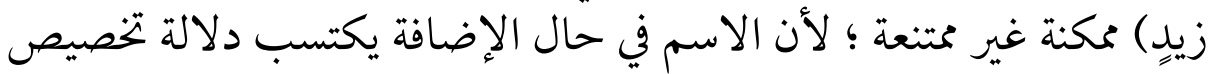

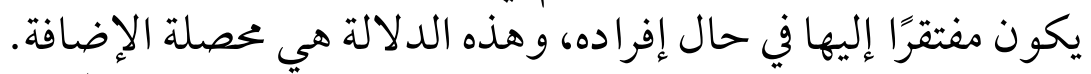

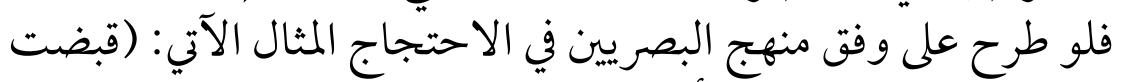

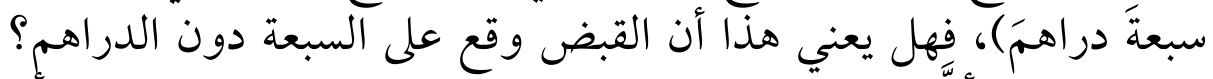

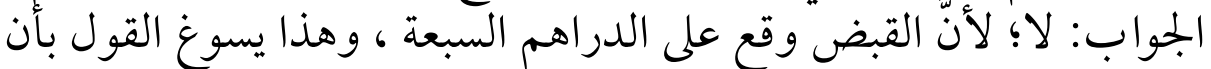

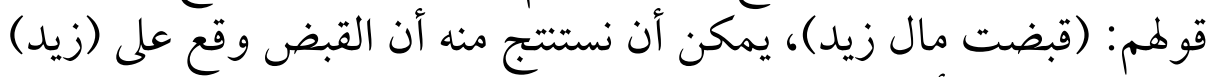

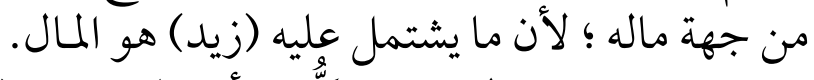

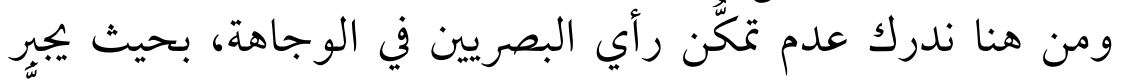

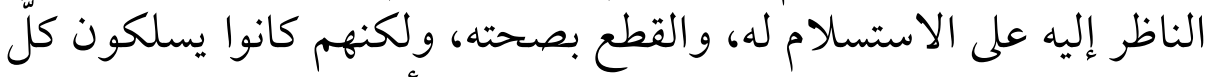

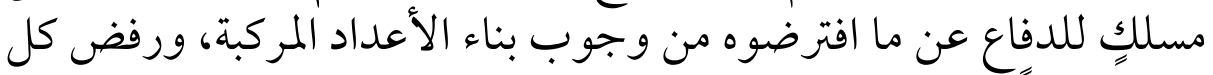
ما جاء مخالفًا له.

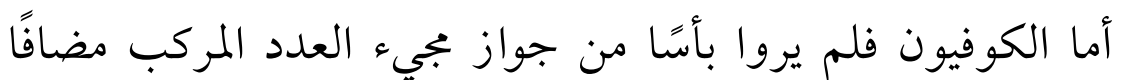

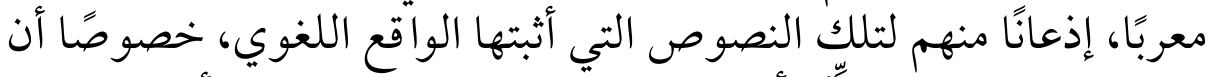

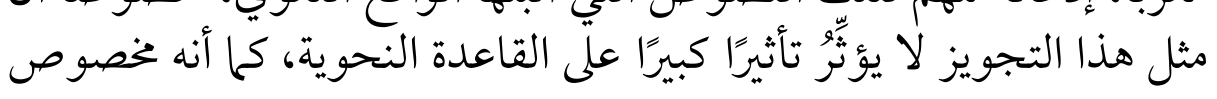
بموضع معين، وصيغة محدودة.

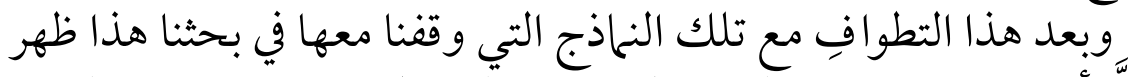

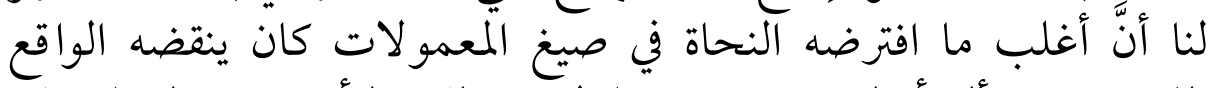

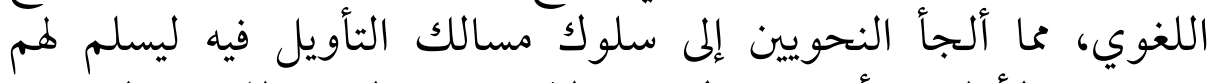

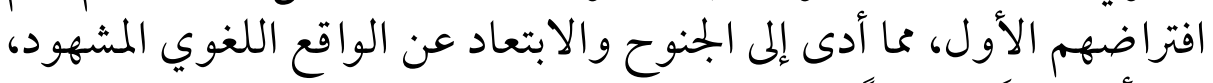

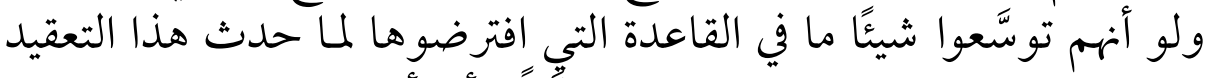

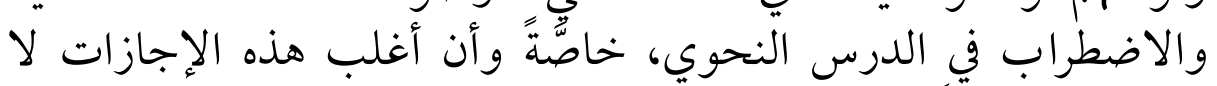

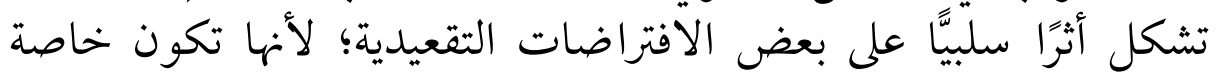

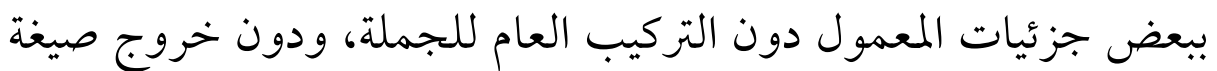

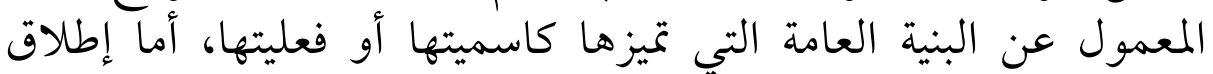

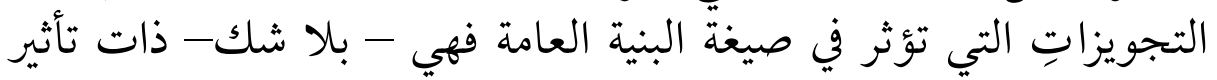
سلبي على القاعدة النحوية. 


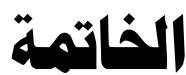

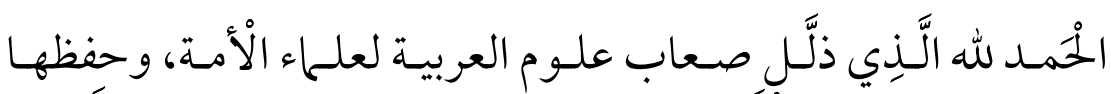

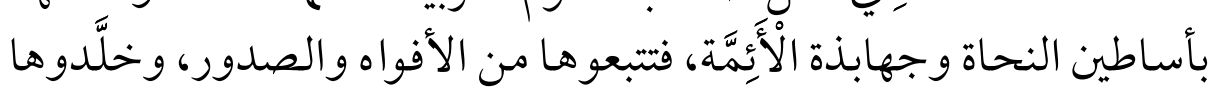

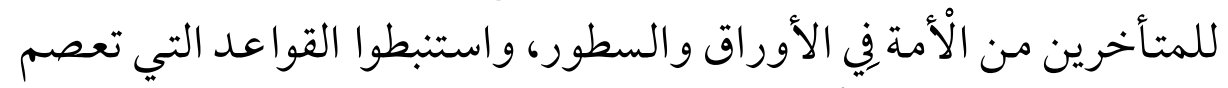

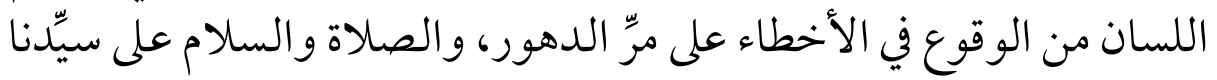

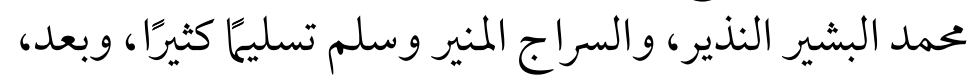

فإنَّ من أهمِّ ما أسفرَ عليه البحث من نتائج ما يأتي:

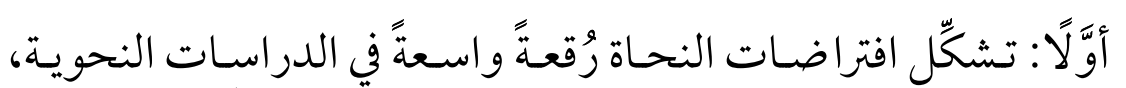

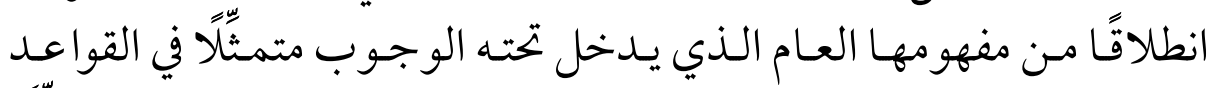

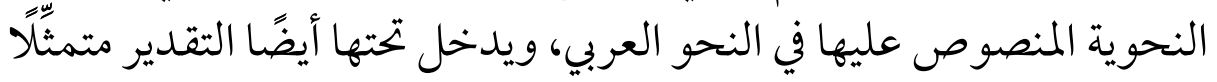

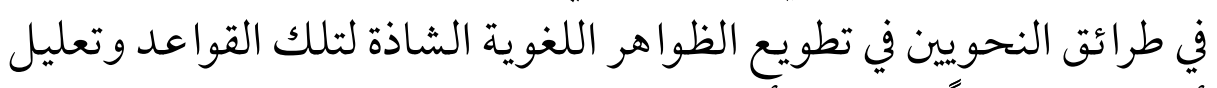

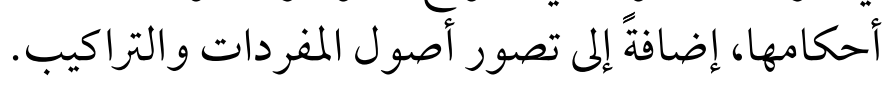

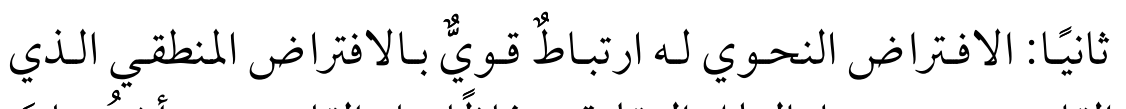

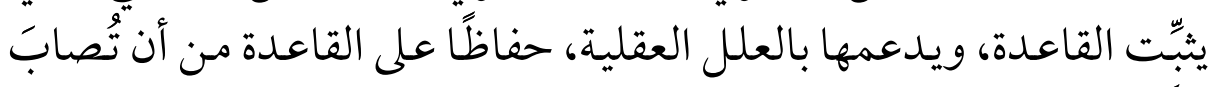

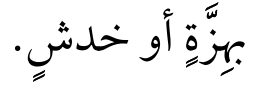

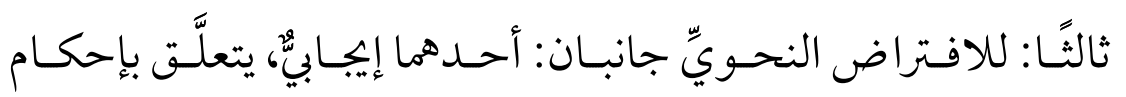

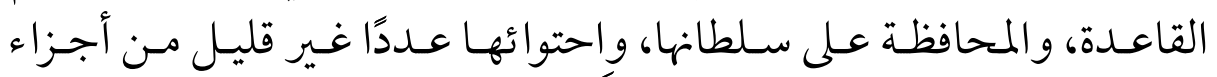

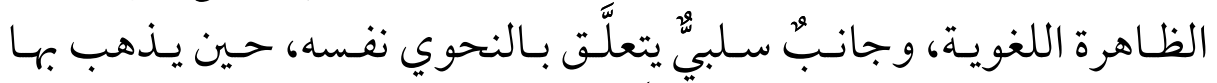

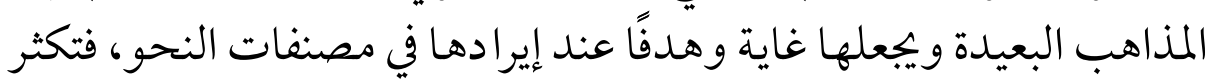

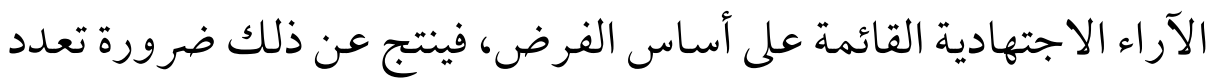

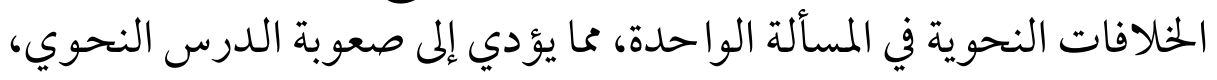




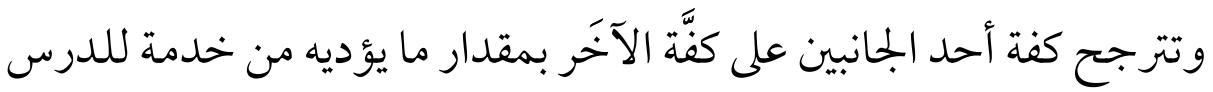

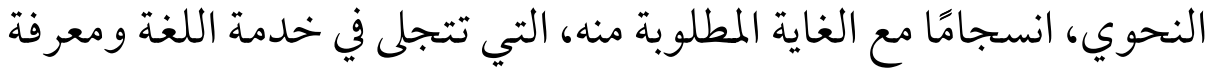

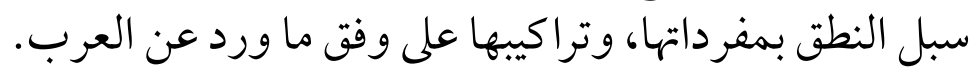

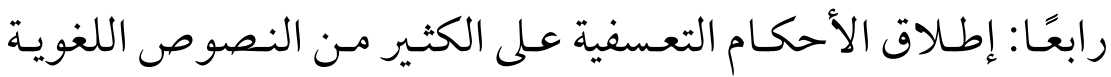

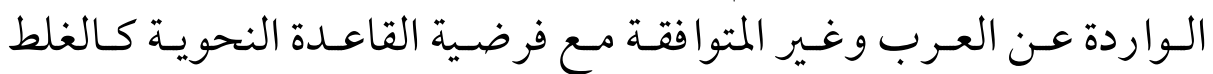

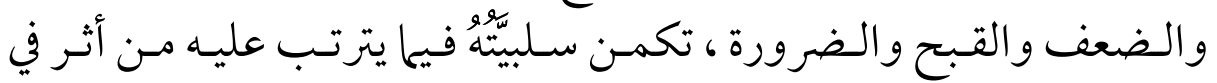
اضعاف القاعدة النحوية.

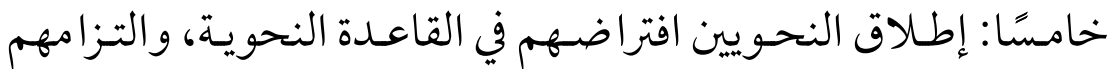

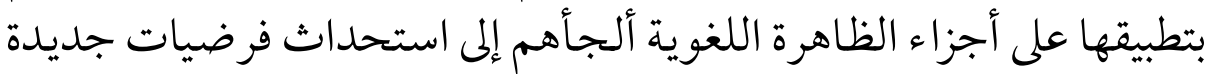

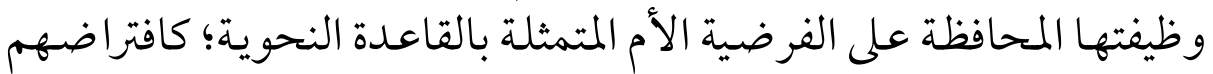

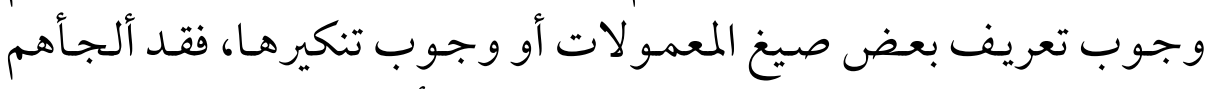

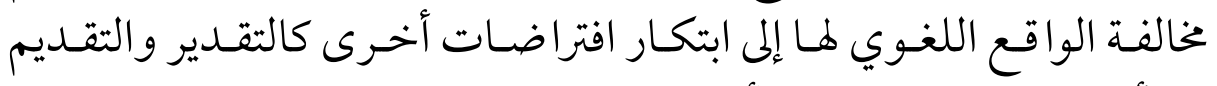

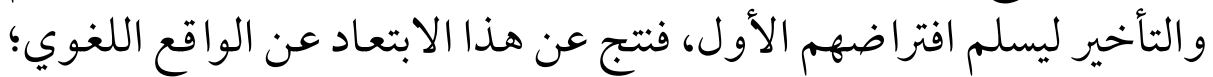

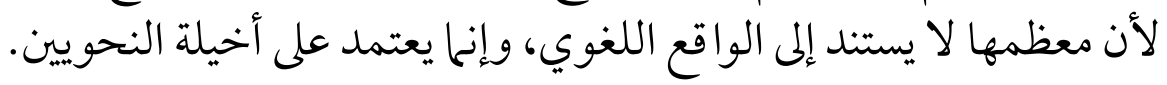

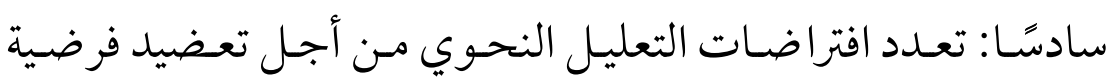

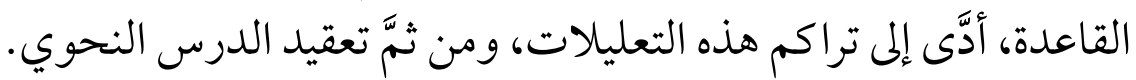

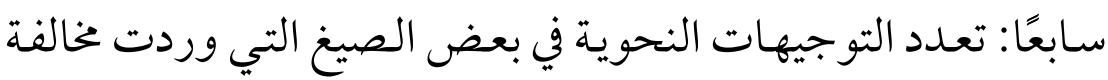

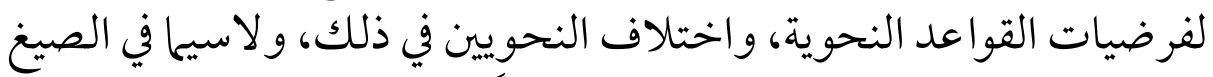

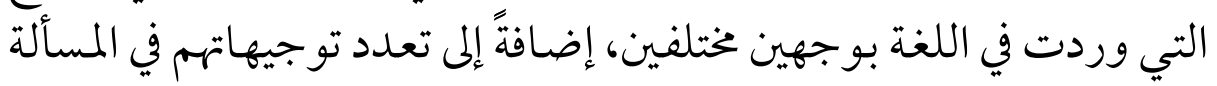

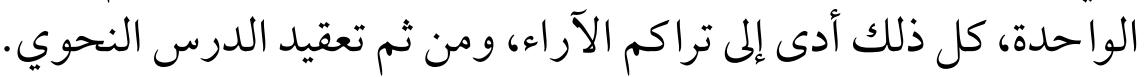

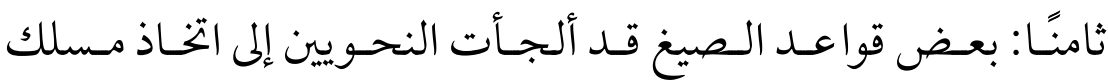

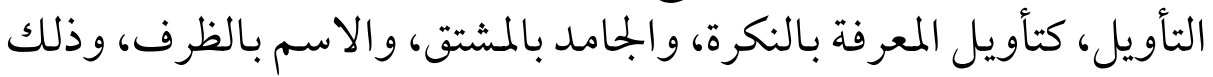




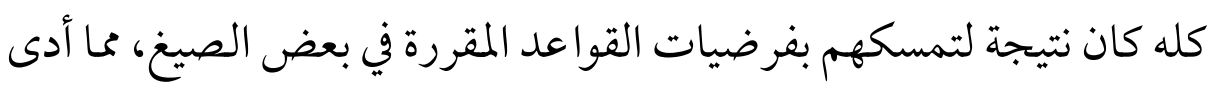
إلى الجنوح، والابتعاد عن الواقع اللغوي المشهود.

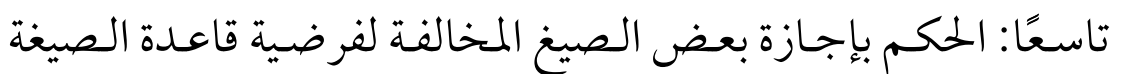

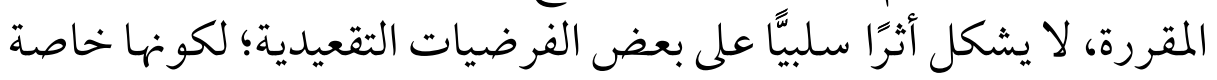

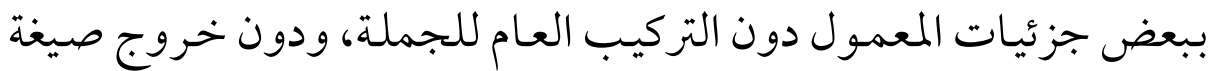

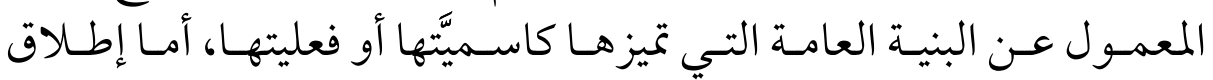

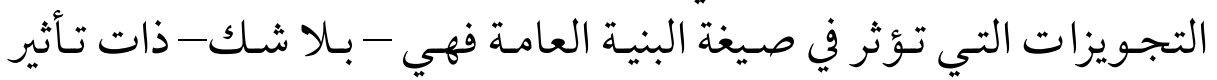
سلبي على القاعدة النحوية.

عاشرًا : قد يلجأ النحويون إلى مفهوم قلب القاعدة في بعض الصيغ المئ

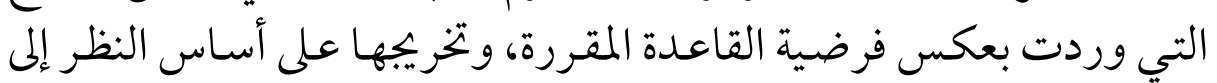
النوع المادي الذي تدل عليه اللفظة بو صفه مسوغًا لهذا القلب.

والحمد لله أولًا وآخرًا. 


\section{مصادر البحث (1)}

أولاً : القرآن الكريهـ.

ثانيًا : المخطوطات والرسائل الجامعية :

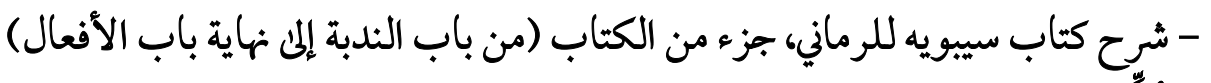

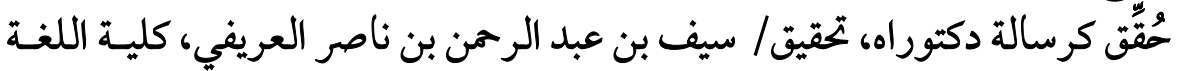

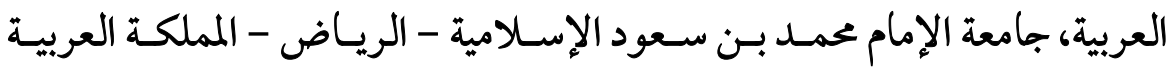

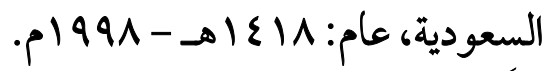

$$
\begin{aligned}
& \text { ثالثًا : المطبوعات : }
\end{aligned}
$$

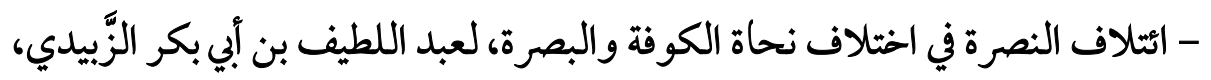

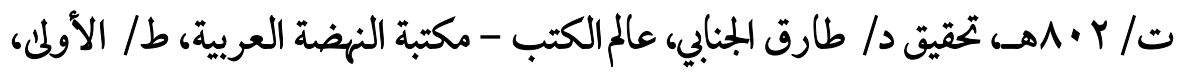

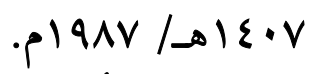

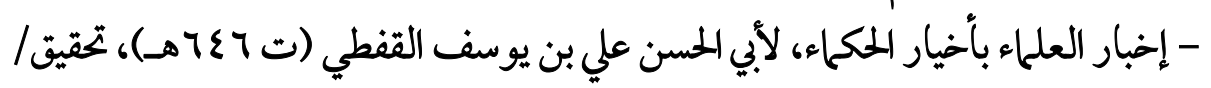

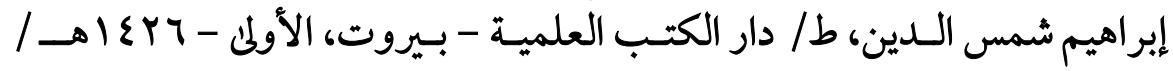

$$
\text { مr.o }
$$

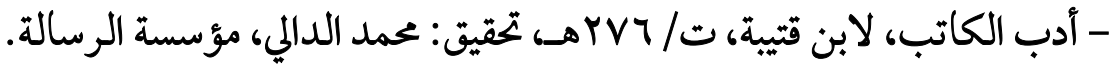

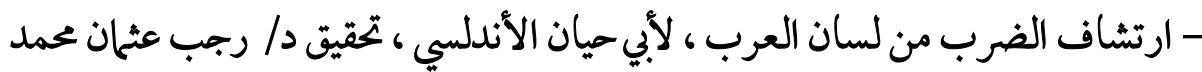

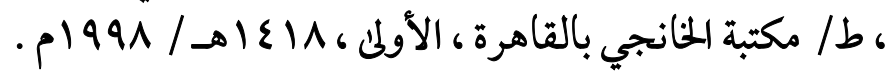

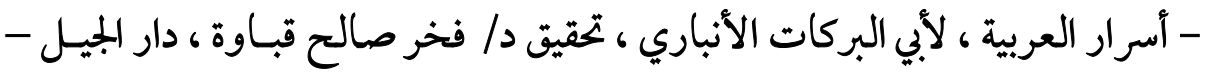

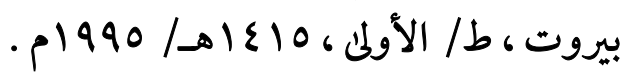

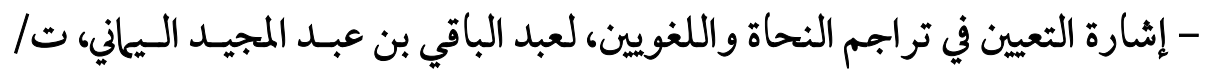

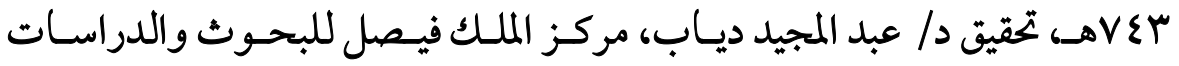

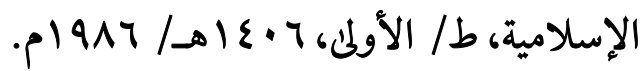

(1) مرتبة هجائيًا حسب الحرف الأول من الكلمـة الأولى بعـد إسقاط (أل) أو (ابـن) أو (أب) إن 


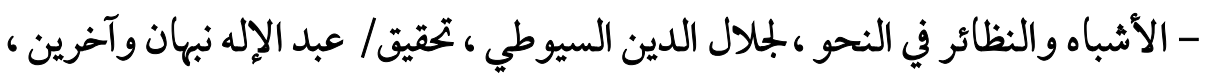

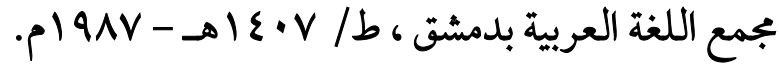

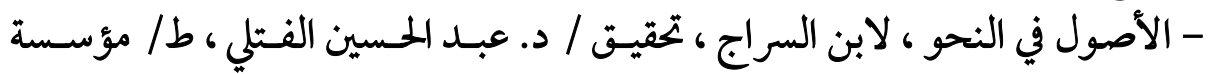

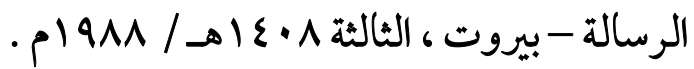

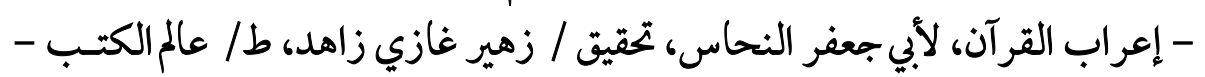

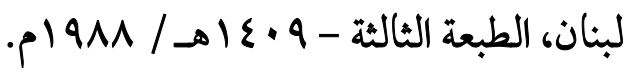

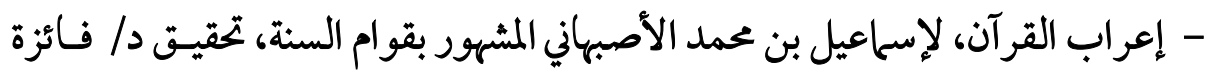

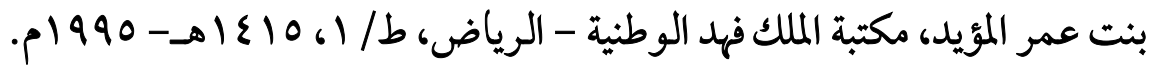

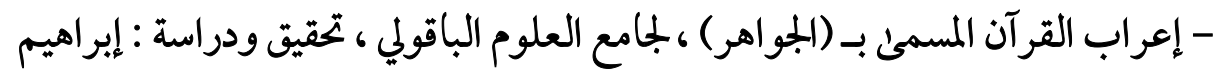

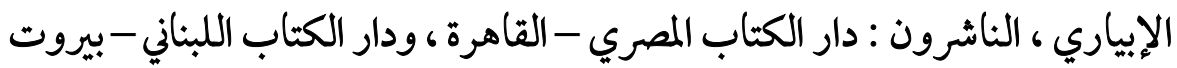

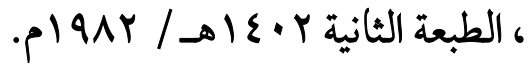

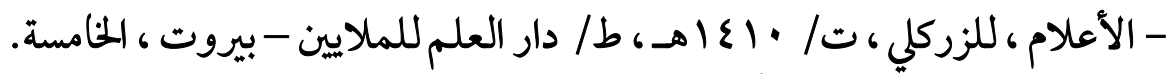

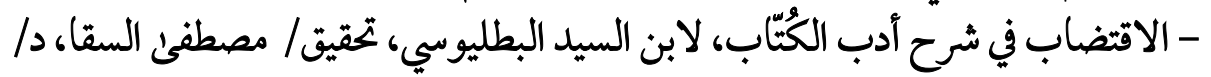

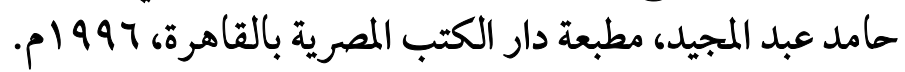

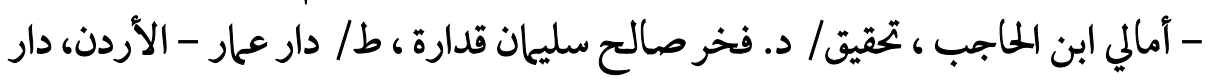

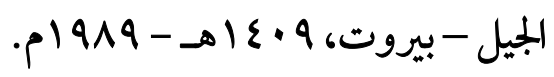

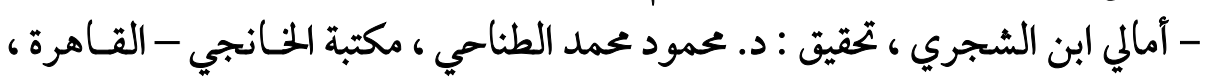

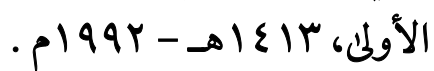

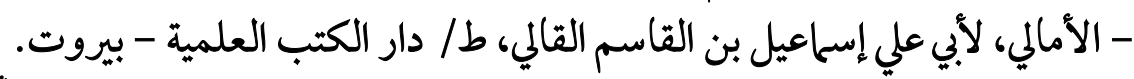

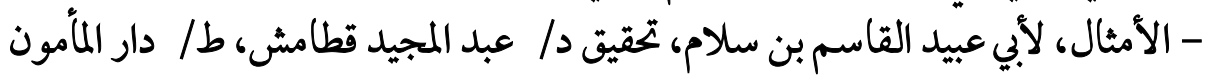

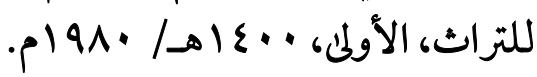

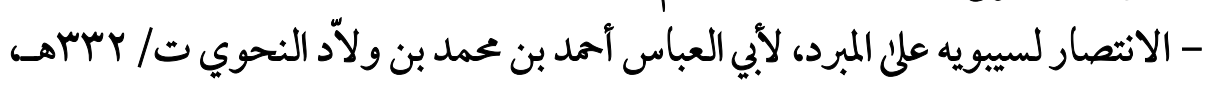

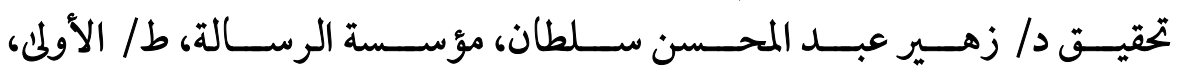
الإنهاف

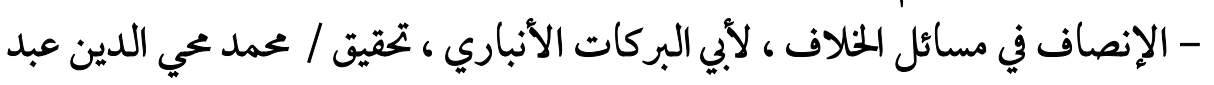

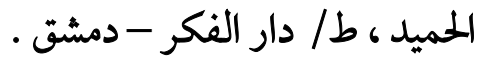




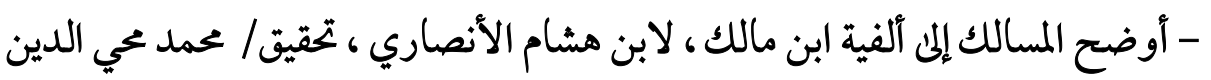

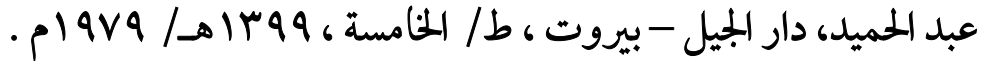

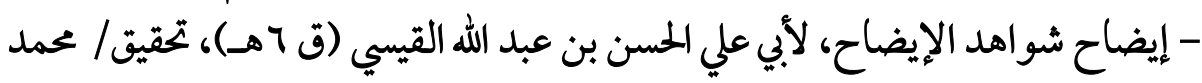

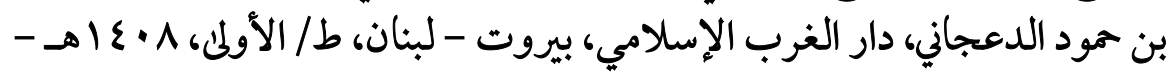

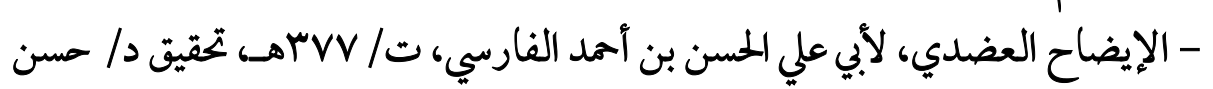

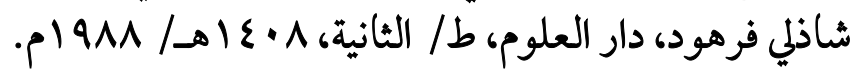

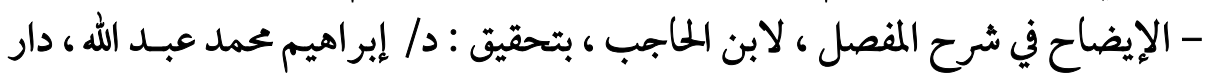

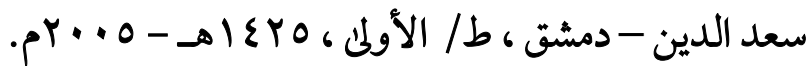

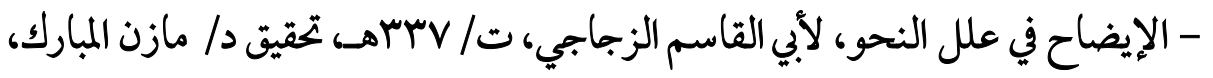

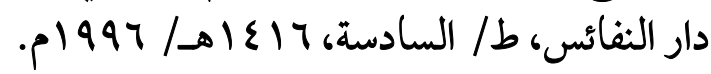

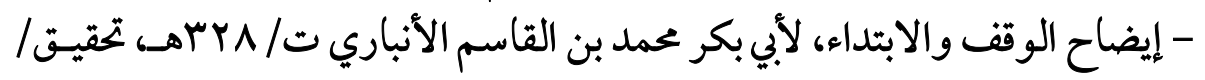

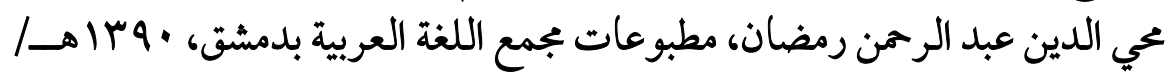
(9V1 - البحر المحيط في التفسير، لأبي حيان الأندلسي، تحقيق/ صدقي محمد جميل، دار الفكر

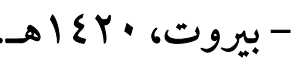

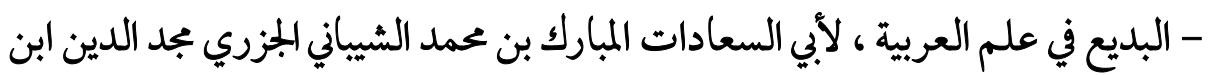

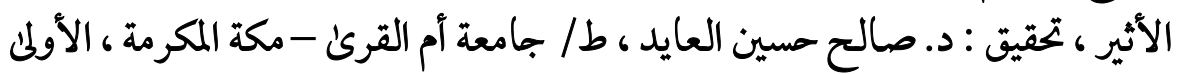

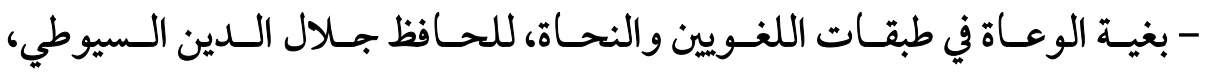

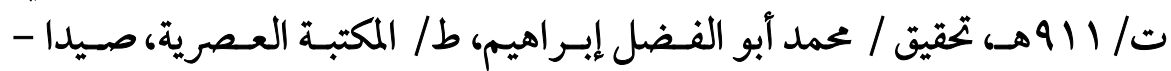

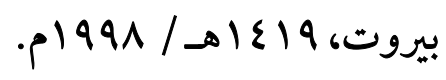
- البيان في غريب إعراب القرآن، لأبي البركات الأنباري، تحقيق: دا طه طه عبد الحميد طه،

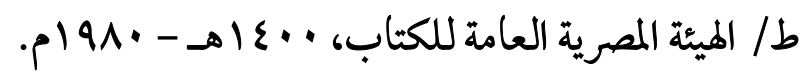

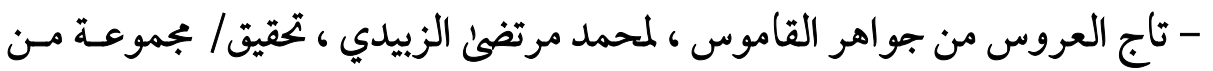

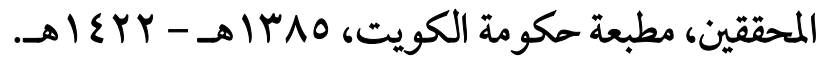




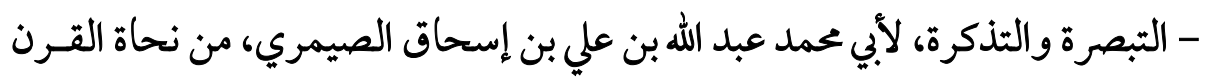

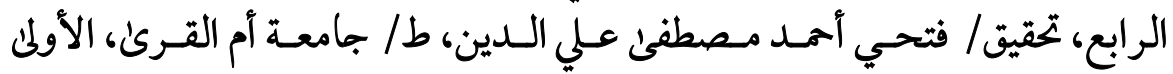

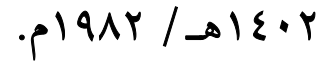
- التبيان في إعراب القرآن ، لأبي البقاء العكبري ، تحقيق/ علي محمد البجاوي، طا / عيسئ البابي الحلبي.

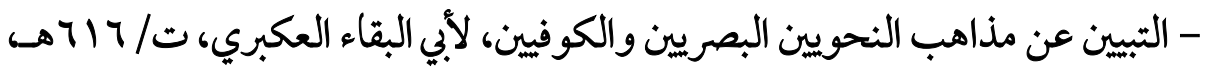

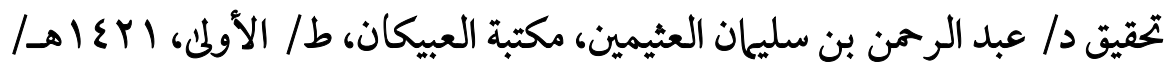
.

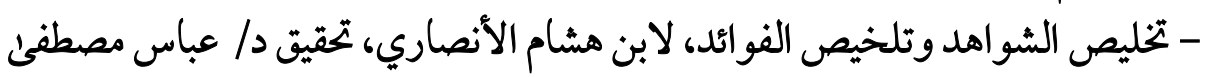

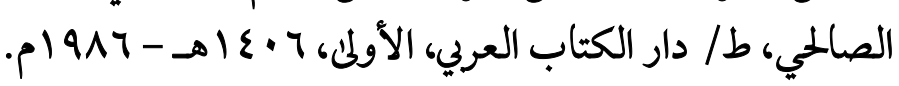

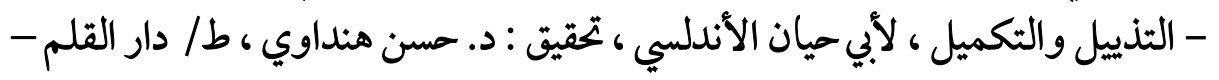

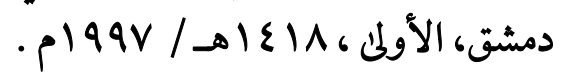

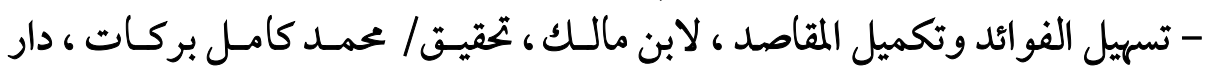

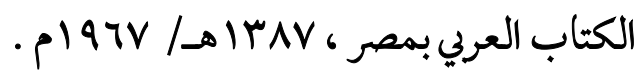

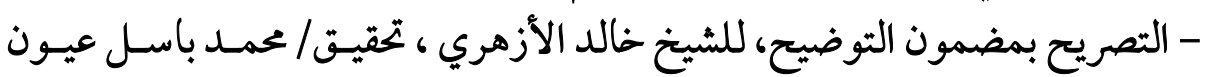

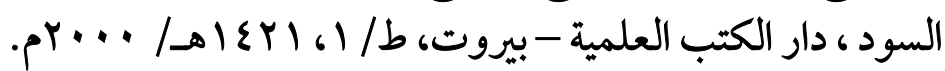

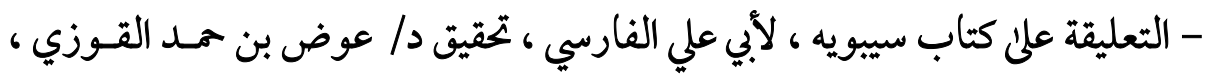

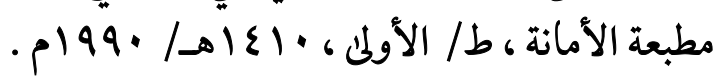

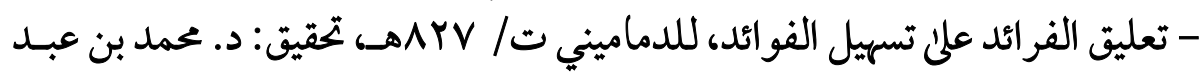

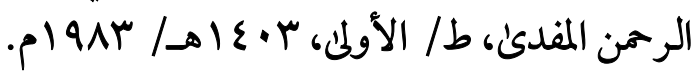

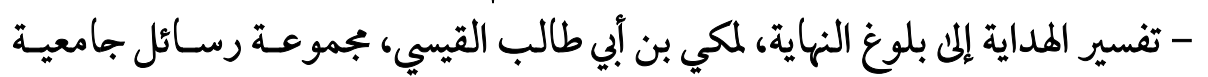

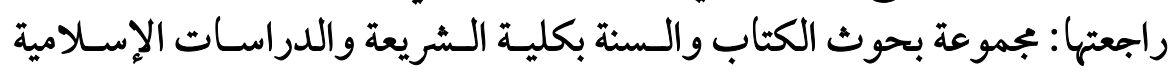

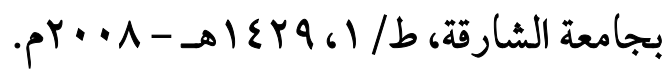

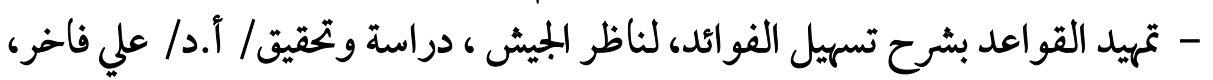

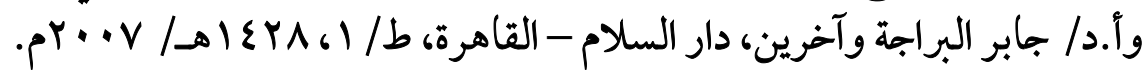




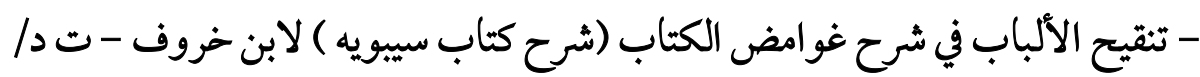

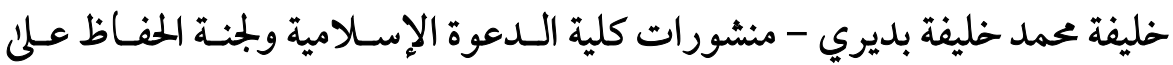

$$
\text { التراث الإسلامي - ليبيا - } 1990 \text { ام. }
$$

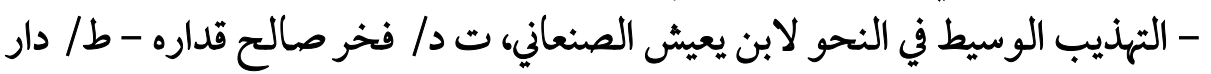

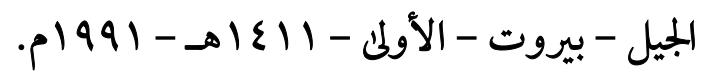

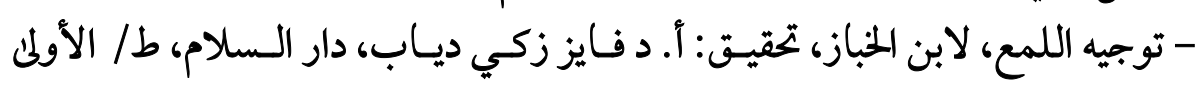

$$
\text { تو }
$$

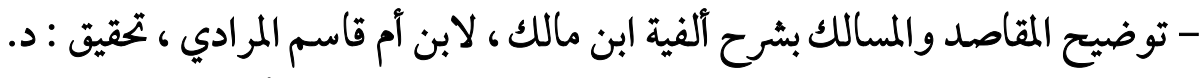

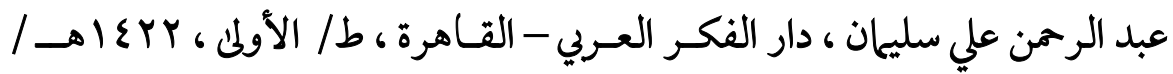

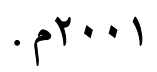

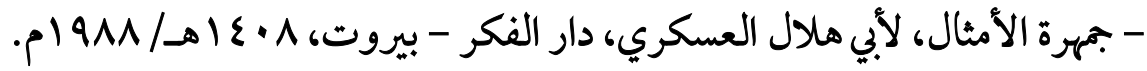

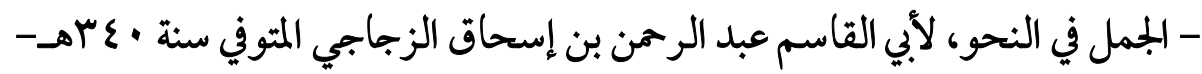

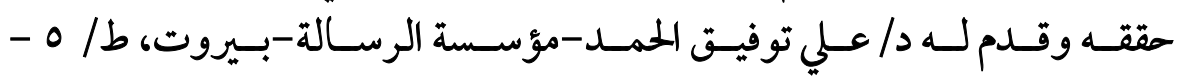

.

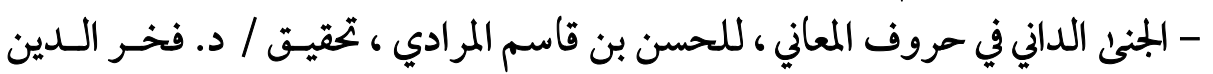

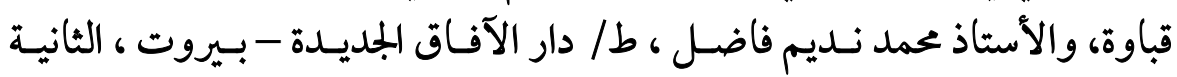

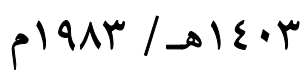

- هاثية يس علن تصريح الأزهري، للشيخ يس بن زام زين الـدين العليمي - القـاهرة، بدون تاريخ.

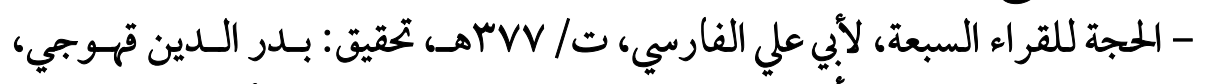

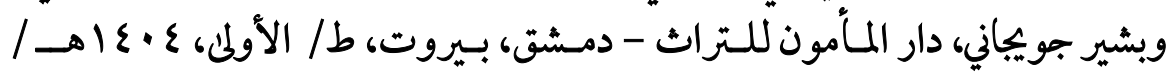

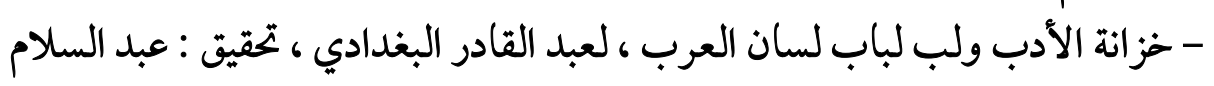

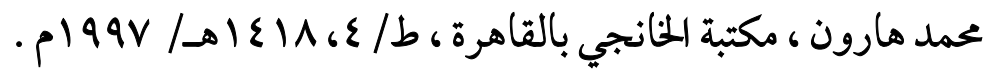

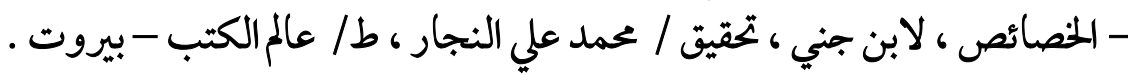

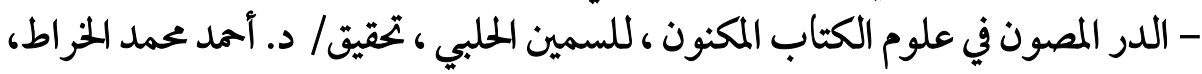

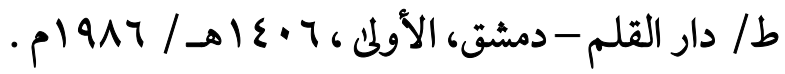




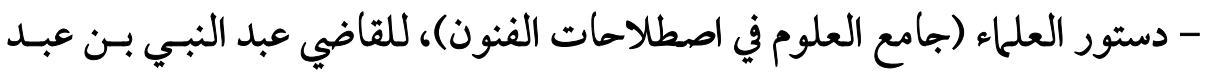

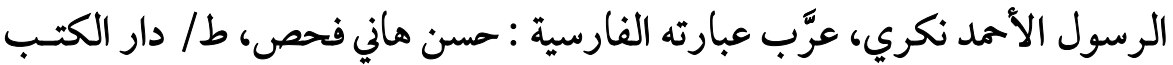

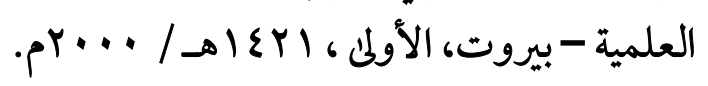

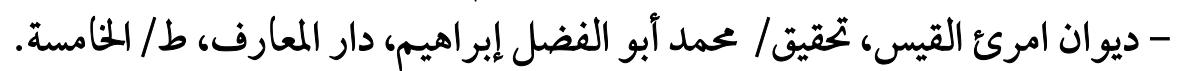

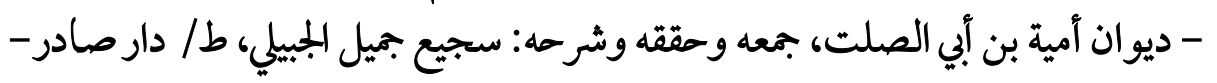

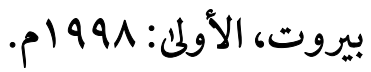

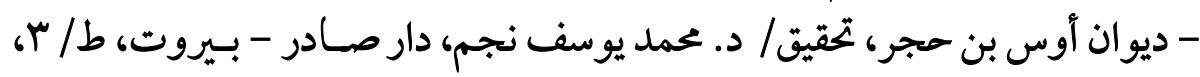

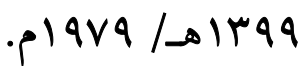

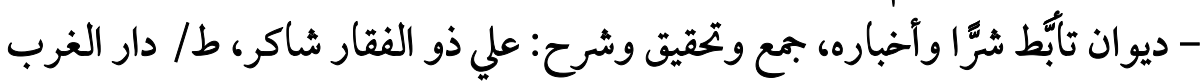

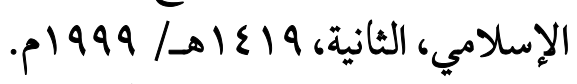

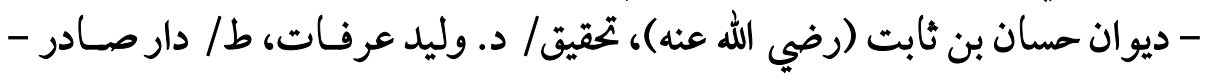

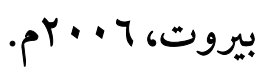

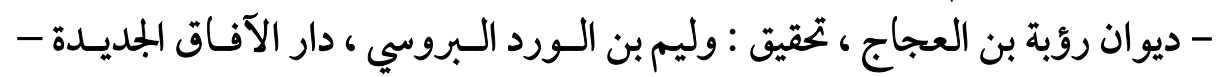

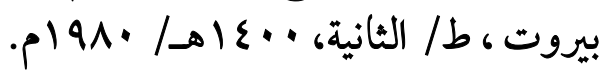

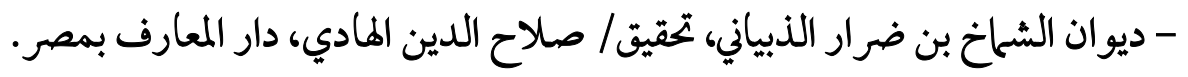

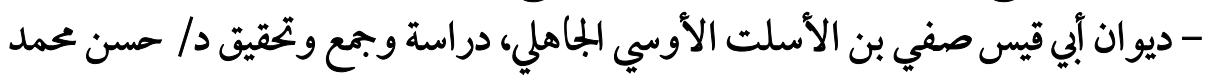

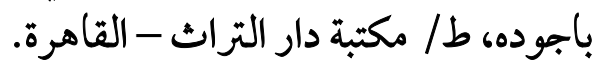

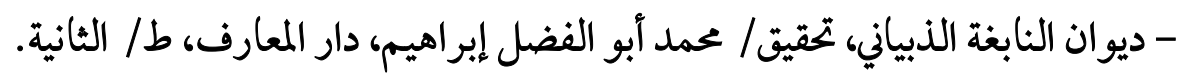

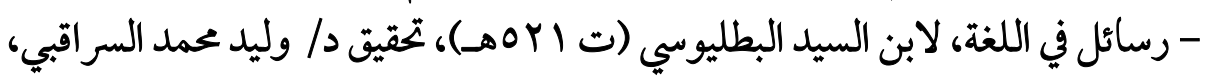

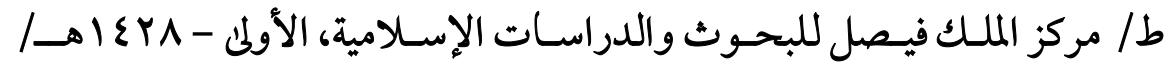

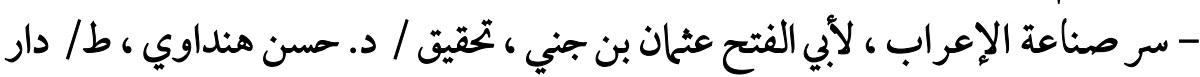

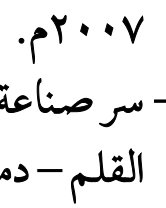

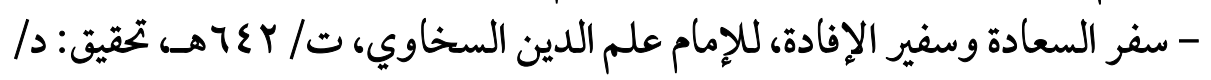

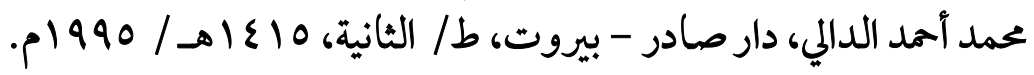

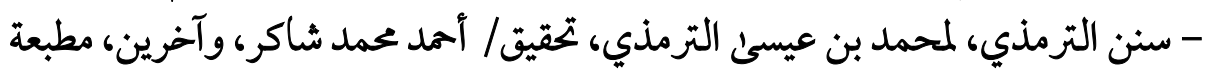

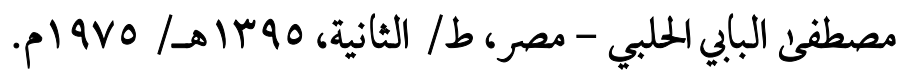


- سنن ابن ماجه ، بتحقيق : محمد فؤاد عبد الباقي ، طا / دار الفكر - بيروت .

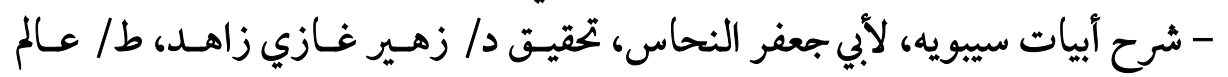

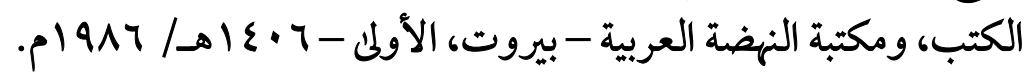

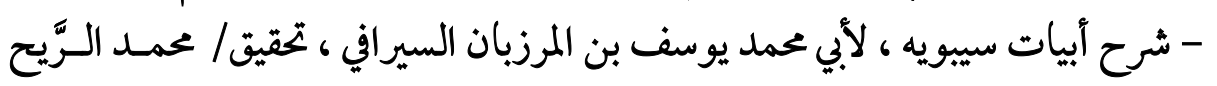

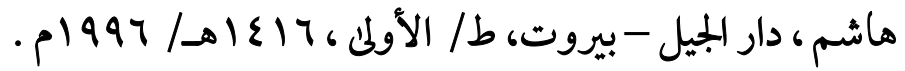

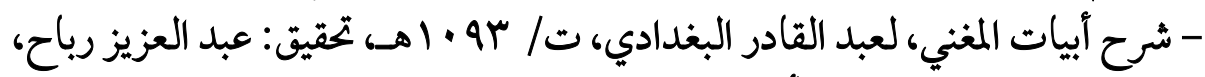

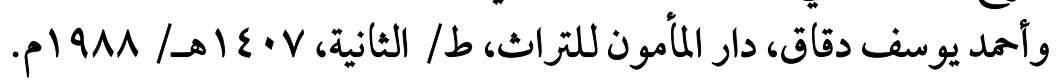

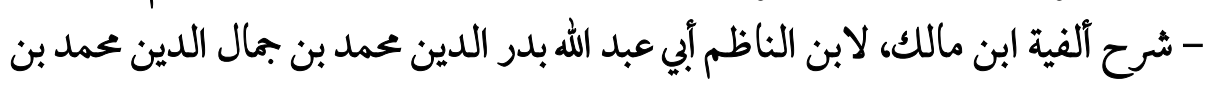

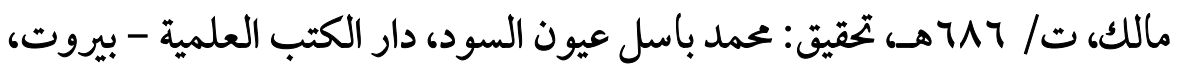

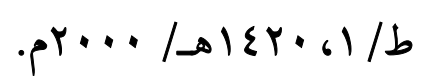

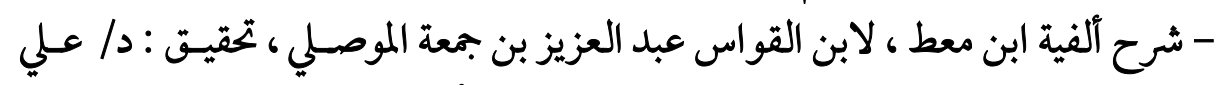

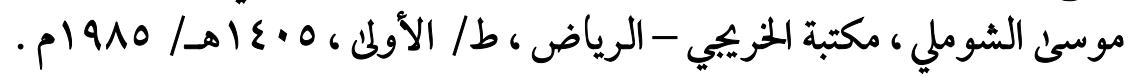

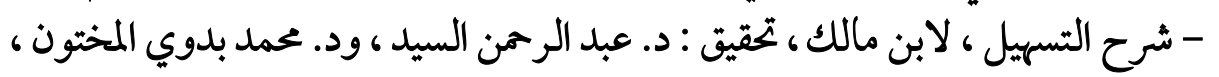

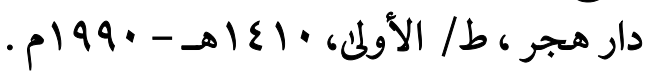

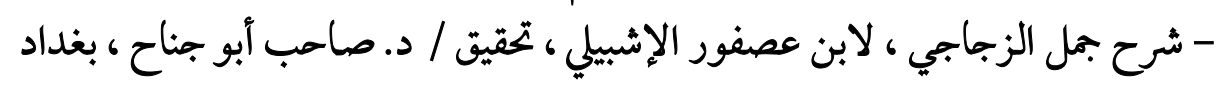
(9Ar

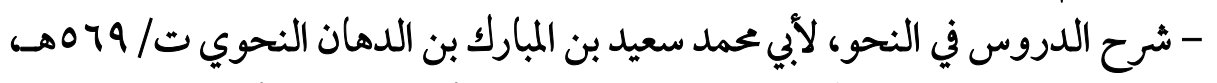

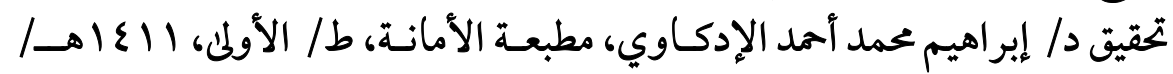
(991

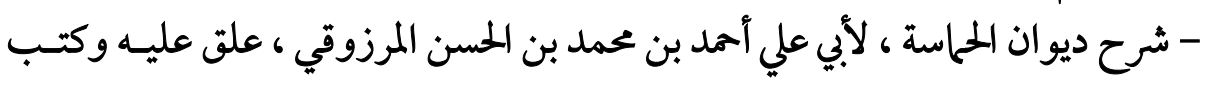

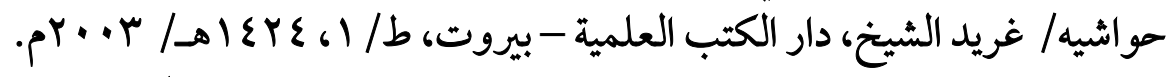

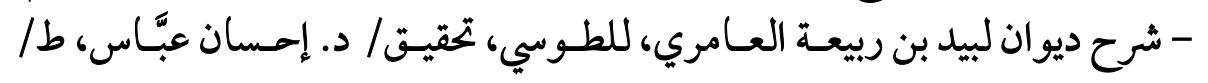

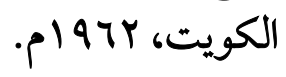

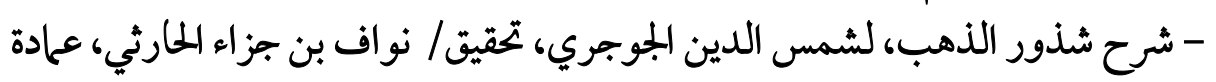

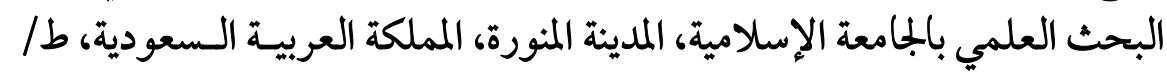

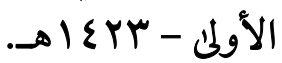




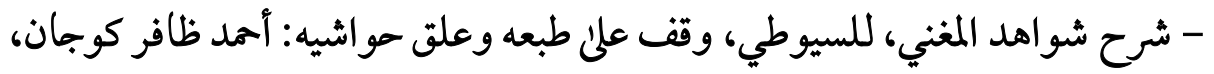

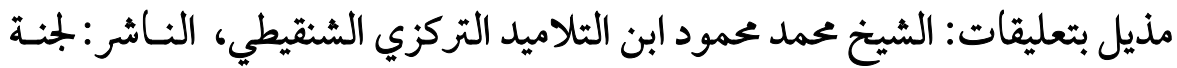

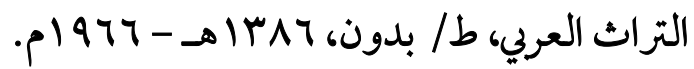

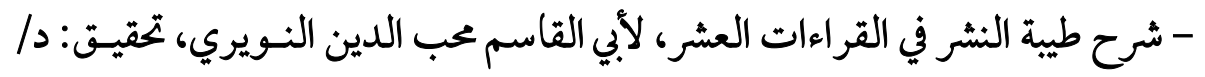

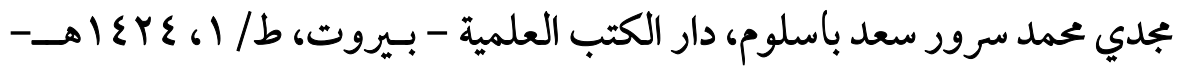
بr

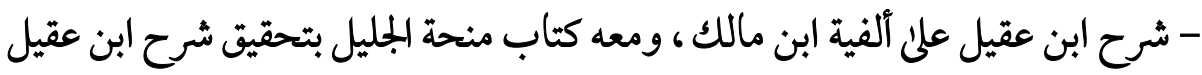

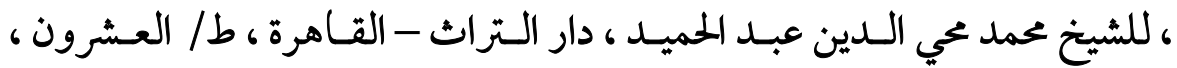

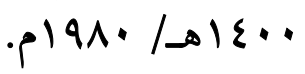

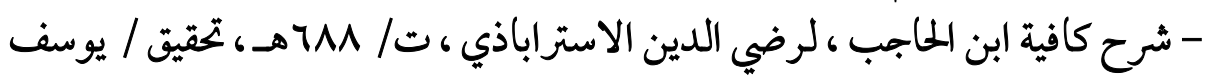

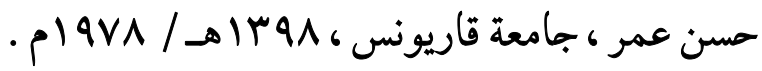

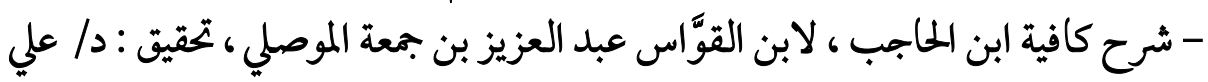

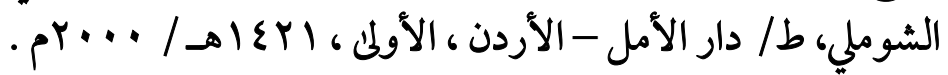

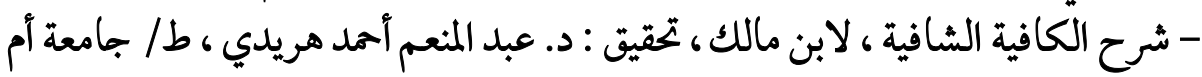
القرئ بمكة المكرمة .

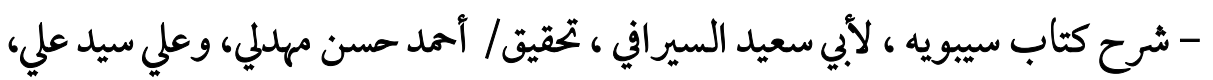

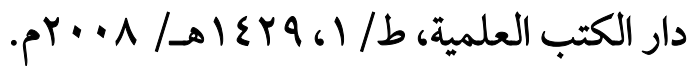

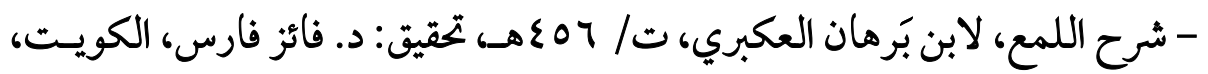

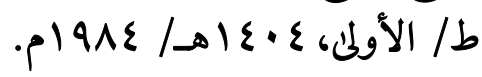

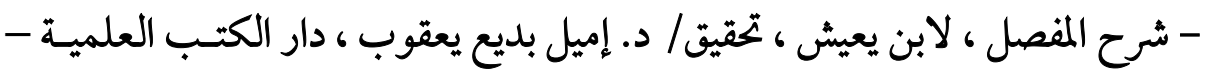

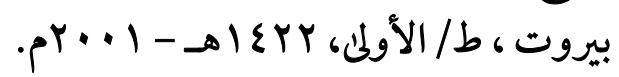

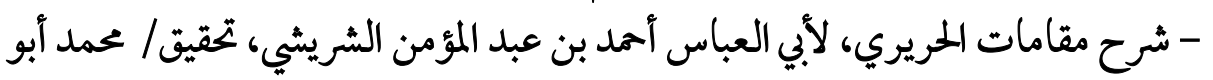

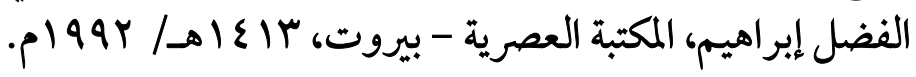

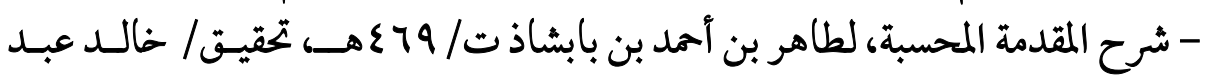

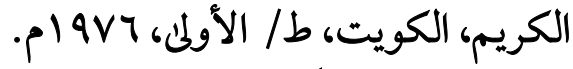

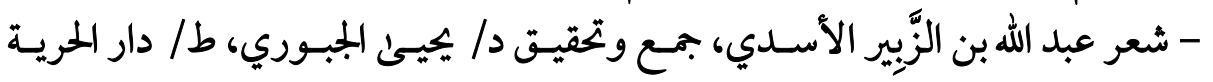

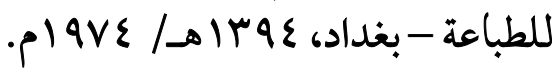




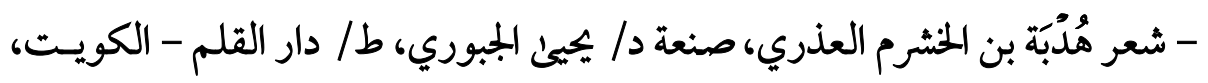

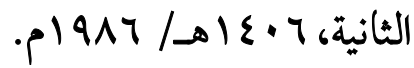

- شواذ القراءات، لأبي نصر الكرماني، تحقيق/ دام د. شمران العجلي، طا مؤسسة البلاغ -

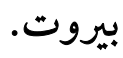

- ضرائر الشعر، لابن عصفور الإشبيلي، تحقيق: الـسيد إبـراهيم محمـد، طا / الثانيـة،

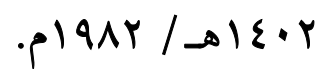

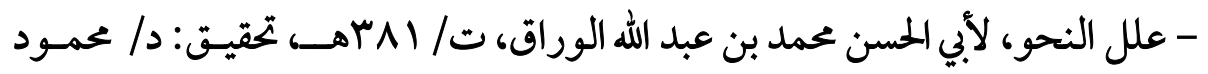

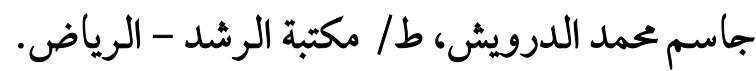

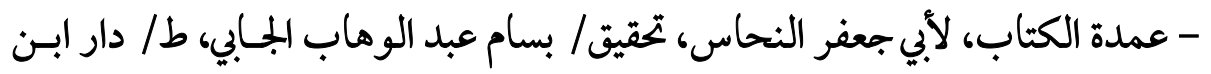

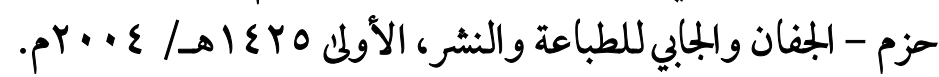

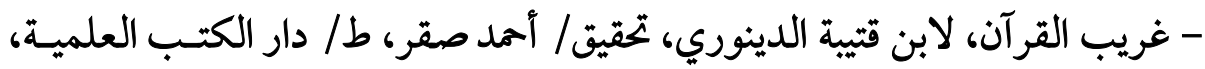

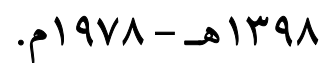

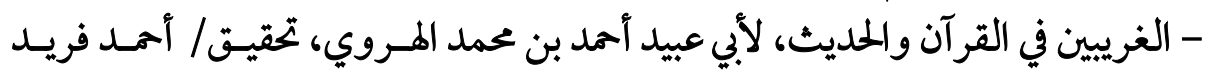

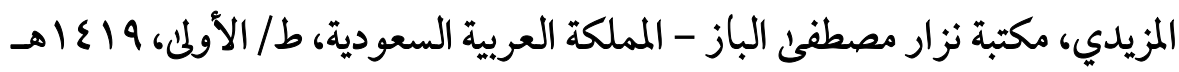
أمان

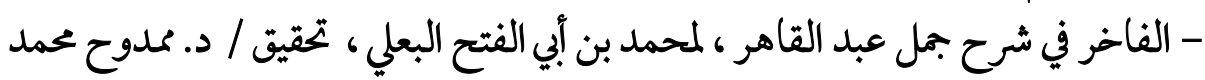

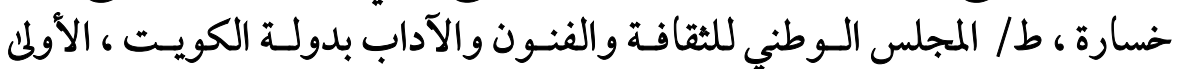

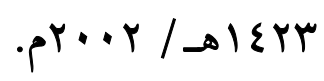

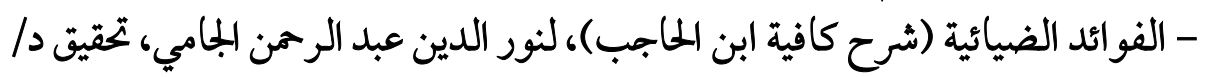

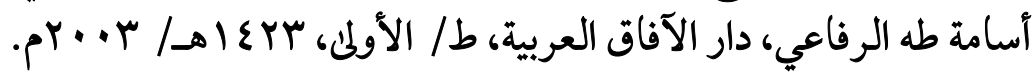

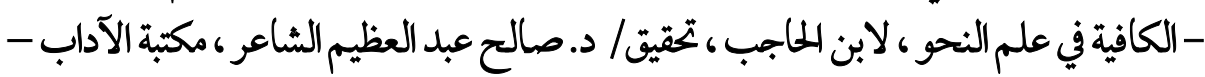

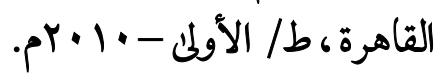

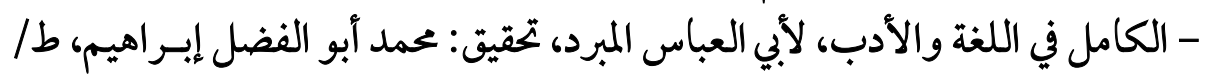

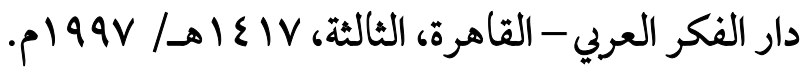

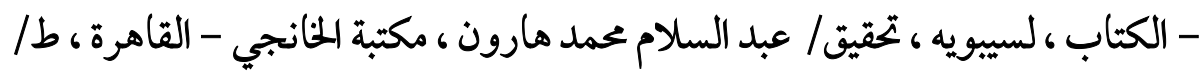

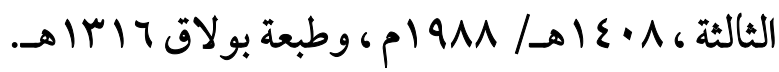


- كتاب الاختيارين، للأخفش الأصغر، تحقيق/ د. فخر الدين قباوة، مؤسسة الرسالة،

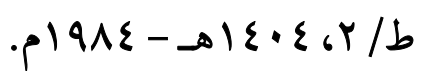

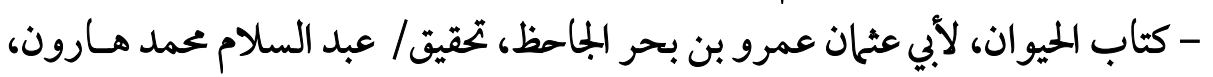

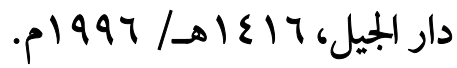

- كتاب الشعر، لأبي علي الفارسي، تمقيق دام/ محمود محمد الطناحي، مكتبة الخانجي القاهرة.

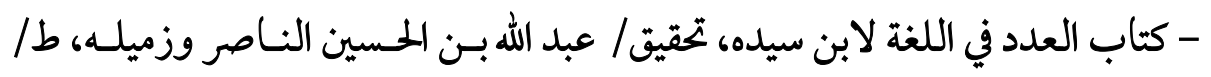

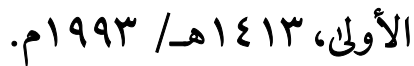

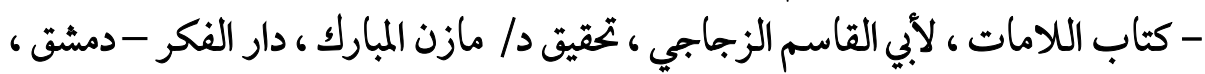

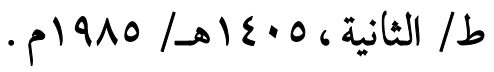

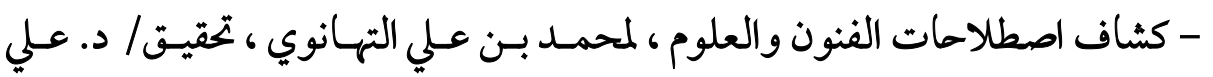

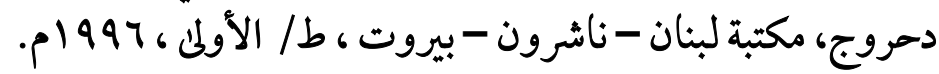

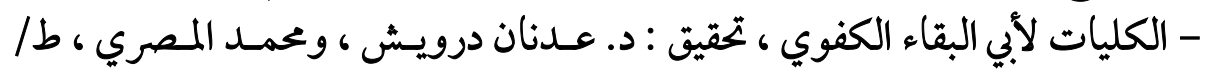

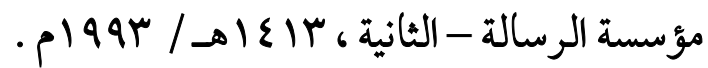

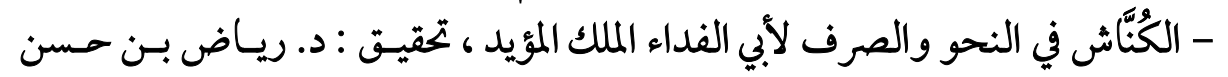

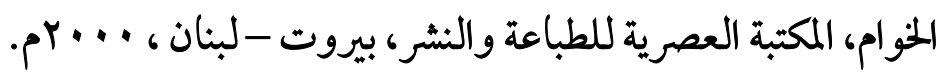

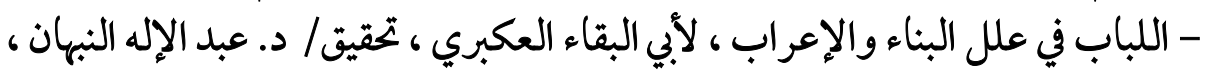

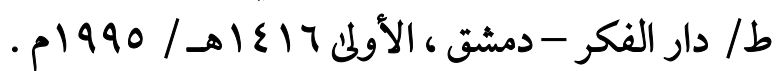

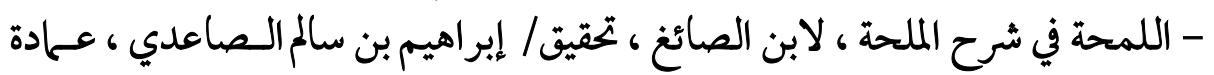

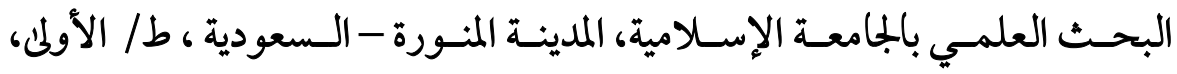

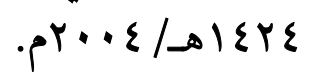

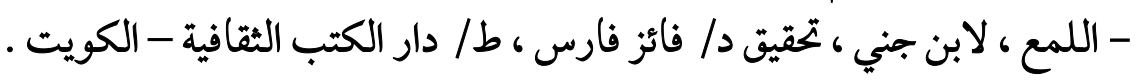

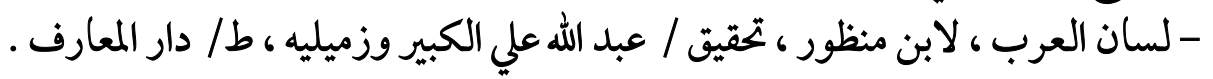

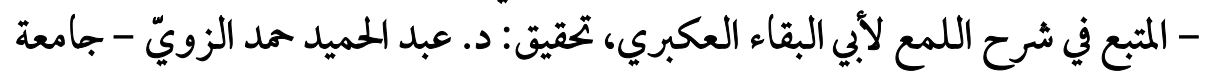

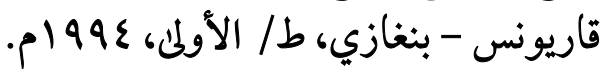
- مجالس ثُعلب ، تحقيق/ عبد السلام هارون ، طال / دار المعارف بمصر ، الطبعة الثانية. 
- بجمع الأمثال، للميداني، ت/ 1 ا Oهـ تحقيق: محمد محي الدين عبد الحميد، دار المعرفة -

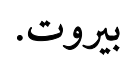

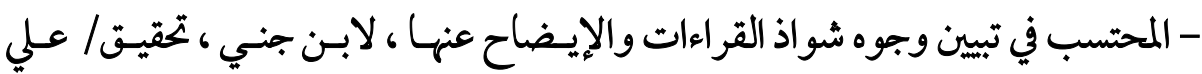

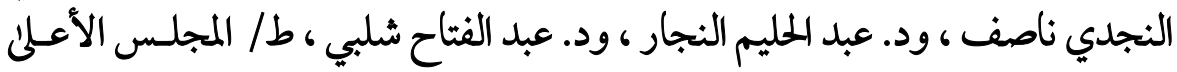

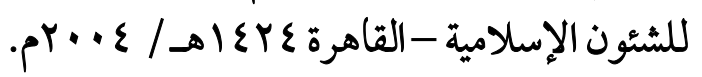

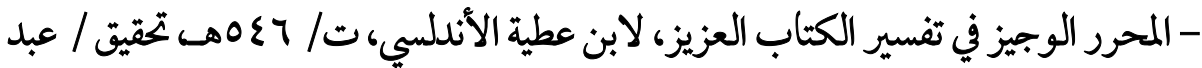

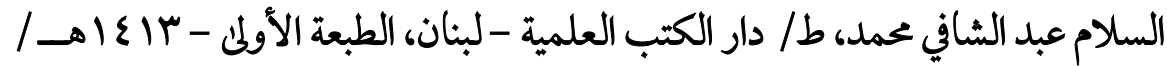

(1994

- المخترع في إذاعة سرائر النحو، للأعلم الشتتمري ، حققه د/ حسن هنداوي ، طا / كنوز

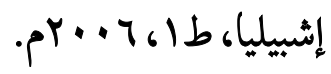

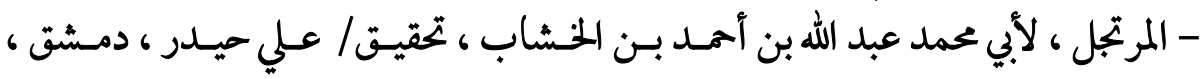

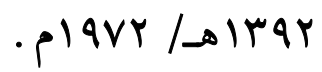

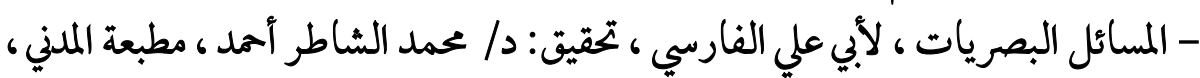

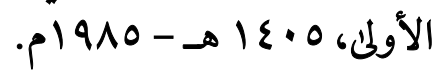

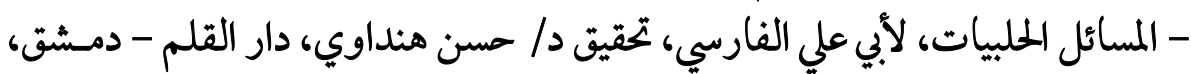

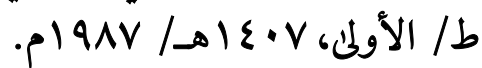

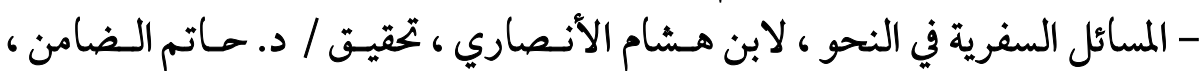

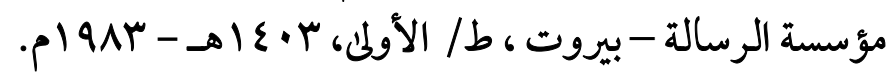

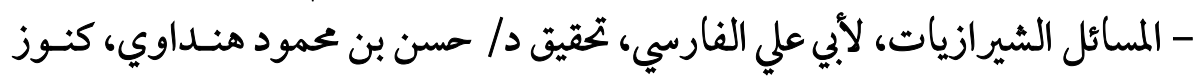

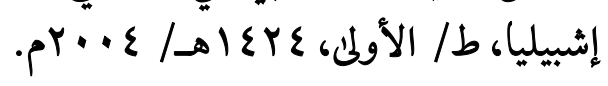

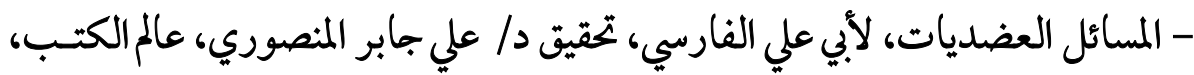

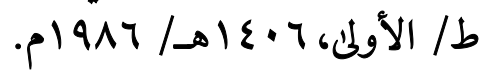

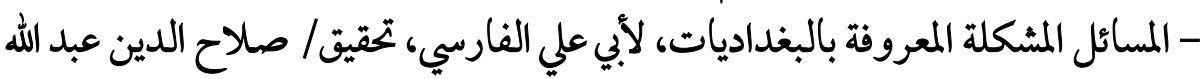
السنكاوي، مطبعة العاني - بغداد.

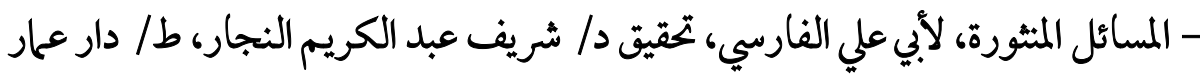

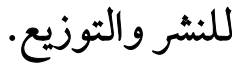




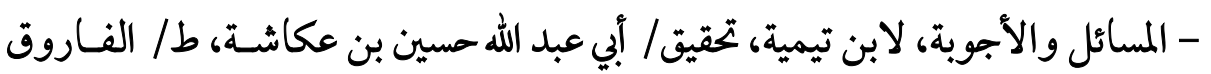

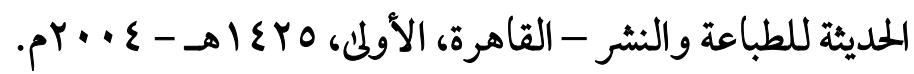

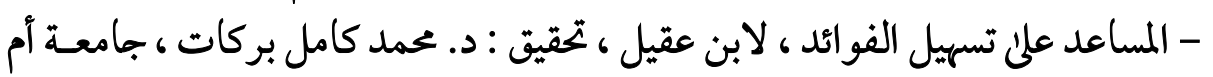

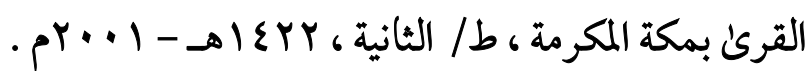

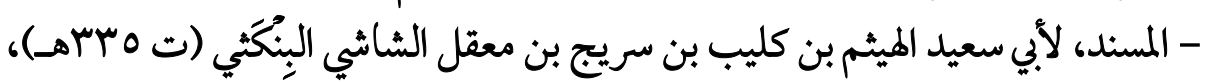

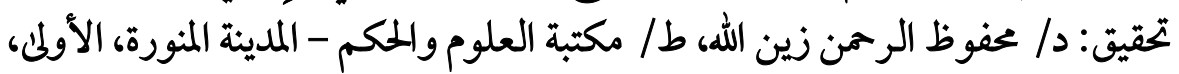
.

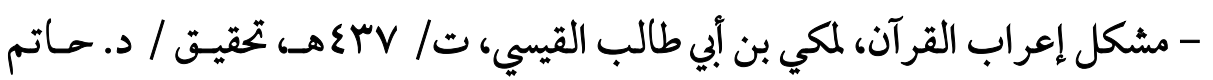

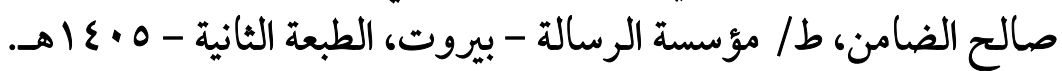

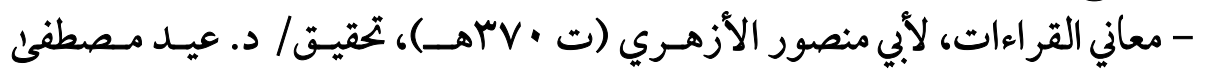

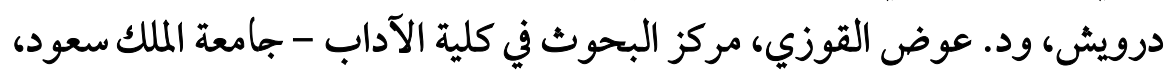

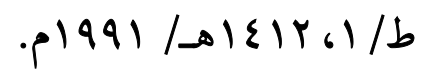

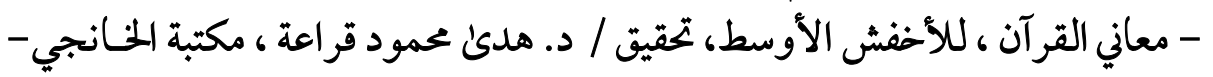

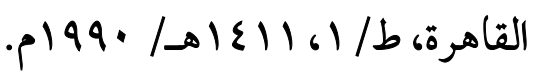

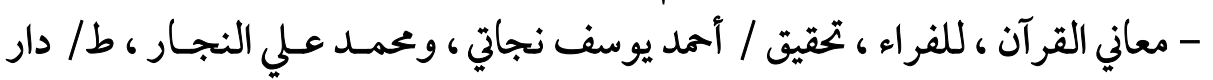

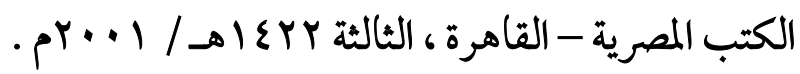

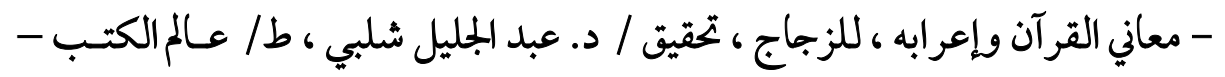

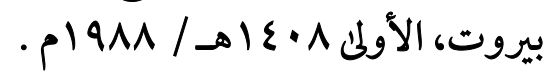

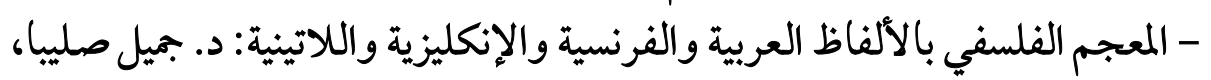

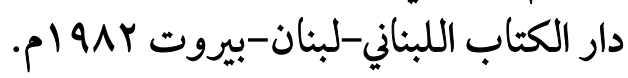

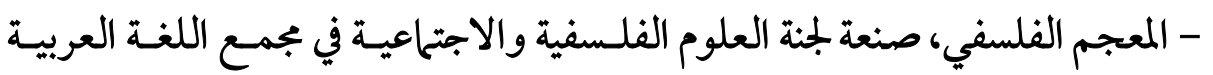

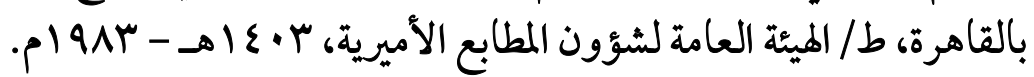

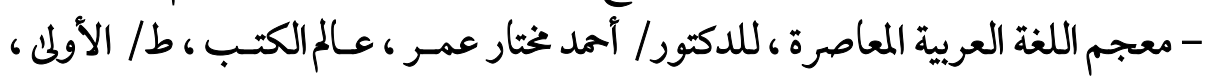

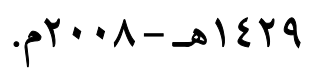

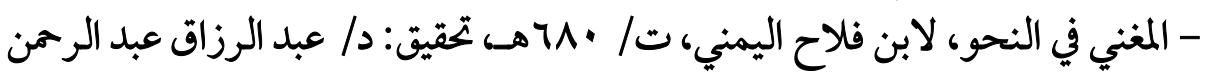

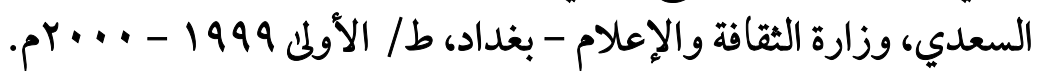




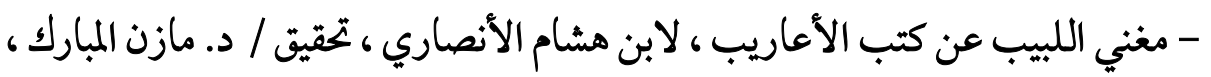

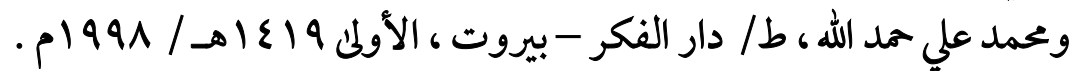

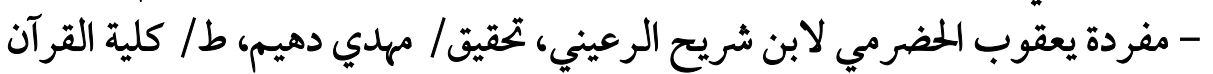

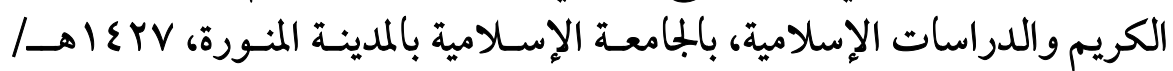

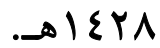

- المفصل في صنعة الإعراب ، للزغخشري ، تمقيق د/ علي بو ملحم ، طا م مكتبة الهلال -

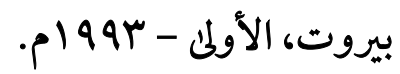
- المفضليات، للمفضل الضبي، تحقيق/ أحمد محمد شاكر، وعبد السلام محمد هارون،

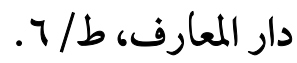
- المقاصد الشافية في شرح الخلاصة الكافية، لأبي إسحاق إبراهيم بن موسئ الشاطبي

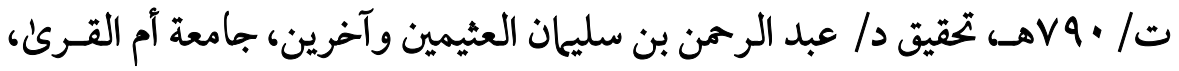

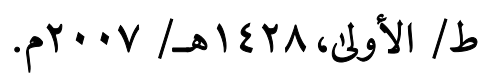

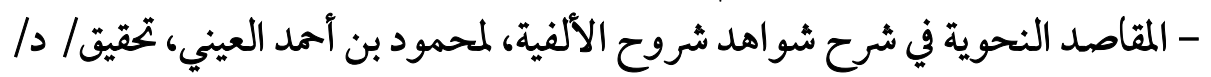

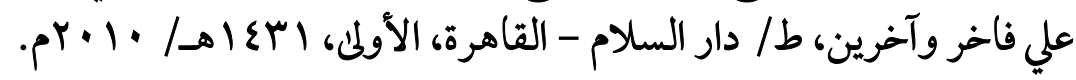

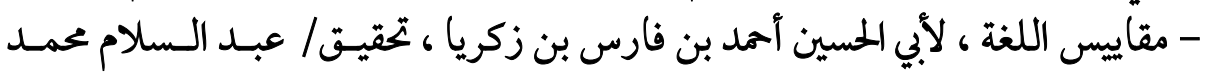

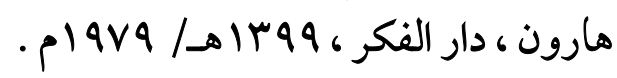

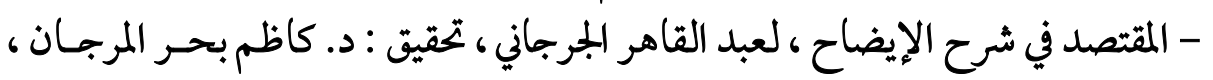

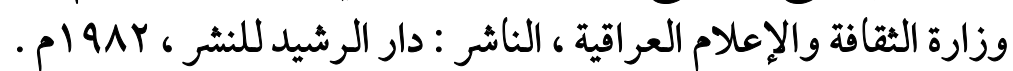

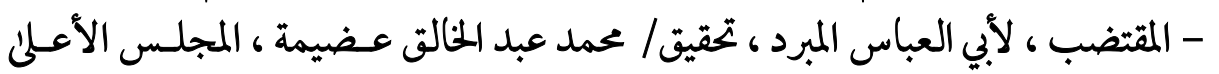

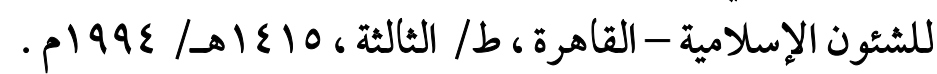

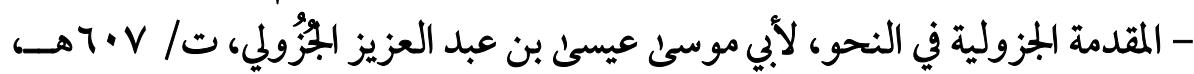

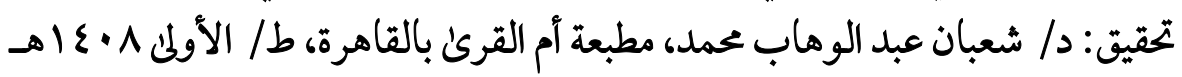

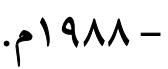
- نتائج الفكر في النحو ، لأبي القاسم السهيلي ، دار الكتب العلميـة - بـيروت، الأولى

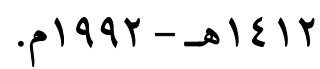

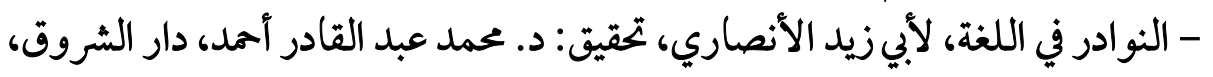

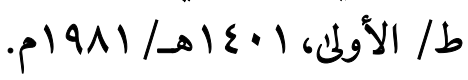




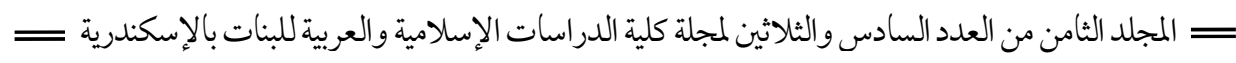

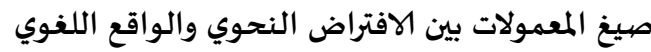

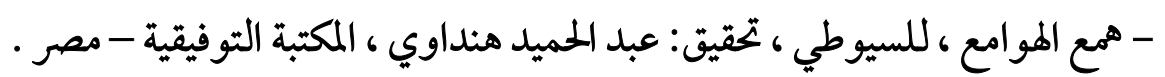

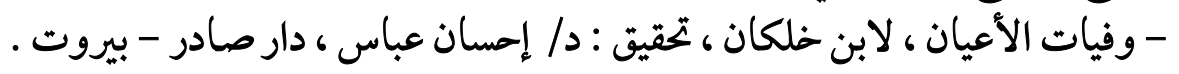

